RPP-RPT-54912, Rev. 0

\title{
Hanford Single-Shell Tank Leak Causes and Locations - 241-A Farm
}

\author{
C.L. Girardot, D.G. Harlow
}

Washington River Protection Solutions

Richland, WA 99352

U.S. Department of Energy Contract DE-AC27-08RV14800

$\begin{array}{lll}\text { EDT/ECN: } & \text { DRF } & \text { UC: N/A } \\ \text { Cost Center: } & \text { 2KE00 } & \text { Charge Code: } 201334 \\ \text { B\&R Code: } & \text { N/A } & \text { Total Pages: } 169 \text { JDA } 9 / 10 / 13\end{array}$

Key Words: leak location, leak cause, tank, integrity assessment, A Farm, A-104, A-105, leak assessment

Abstract: This document identifies 241-A Tank Farm (A Farm) leak causes and locations for the 100 series leaking tanks (241-A-104 and 241-A-105) identified in RPP-ENV-37956, Hanford A and AX Farm Leak Assessment Report. This document satisfies the A Farm portion of the target (T04) in the Hanford Federal Facility Agreement and Consent Order milestone M-045-91F.

TRADEMARK DISCLAIMER. Reference herein to any specific commercial product, process, or service by trade name, trademark, manufacturer, or otherwise, does not necessarily constitute or imply its endorsement, recommendation, or favoring by the United States Government or any agency thereof or its contractors or subcontractors.

\section{APPROVED}

By Janis D. Aardal at 10:54 am, Sep 10, 2013

Release Approval
Date

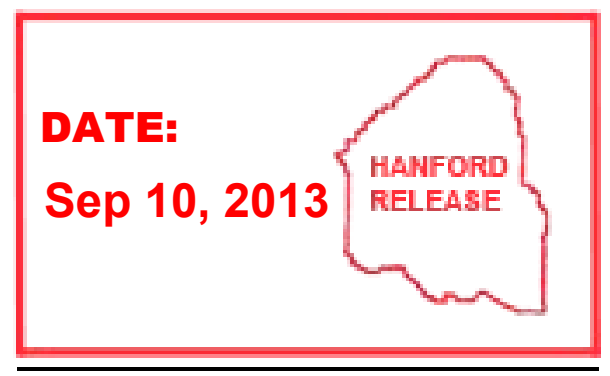

Release Stamp

\section{Approved For Public Release}


RPP-RPT-54912, Rev. 0

\section{EXECUTIVE SUMMARY}

This document identifies 241-A Tank Farm (A Farm) leak causes and locations for the 100-series leaking tanks in A Farm. The leak causes and locations report for all of the 100-series singleshell leaking tanks is one of the targets (M-045-91-T04) in the Hanford Federal Facility Agreement and Consent Order milestone M-045-91F. The T04 target requires that the Department of Energy (DOE) provide to State of Washington, Department of Ecology (Ecology) a report on the 100-series single-shell tanks which have been or will be identified as having leaked in RPP-32681, Rev. 0, Process to Assess Tank Farm Leaks in Support of Retrieval and Closure Planning, leak assessment reports.

The leak assessment report for A Farm, RPP-ENV-37956, Hanford A and AX Farm Leak Assessment Report, lists two 100-series tanks that continue to be classified leaking tanks in A Farm, 241-A-104 (A-104) and 241-A-105 (A-105). One tank, 241-A-103 (A-103), previously classified as a leaking tank was identified in RPP-RPT-37956 as requiring re-assessment of the classification per TFC-ENG-CHEM-D-42, Tank Leak Assessment Process. The tank A-103 re-assessment, RPP-ASMT-42278, Tank 241-A-103 Leak Assessment Report, recommended that the classification be changed to "Sound." The remaining three 100-series tanks in A Farm are classified as sound.

This A Farm leak causes and locations document is part of a series of tank farm reports that identify leak causes and locations for 100-series leaking tanks. A summary and conclusions document will be issued, RPP-RPT-54909, Hanford Single-Shell Tank Leak Causes and Locations - Summary, that compiles the results from all of the leak causes and locations tank farm reports when they have been issued which will fulfill the T04 target requirements.

Identification of tank leak locations focused on liquid level data and radioactivity detected in drywells and laterals. Tank A-104 was first suspected of leaking in March 1975 due to radioactivity being detected in lateral 14-04-02 under the northern portion of the tank shortly after the start of sluicing in September 1974. Radioactivity continued to increase and sluicing was halted in April 1975 and the supernatant was pumped. Additional radioactivity was detected spreading eastward and under the southern portion of the tank through May 1975 and appeared to stabilize by the end of 1975 .

Tank A-105 was first suspected of leaking in November 1963 when radioactivity was first detected in lateral 14-05-03 under the south east portion of tank A-105. A sidewall leak was postulated as the liquid level had just been increased from 260-in to 280-in. Radioactivity in lateral 14-05-03 declined after reducing the liquid level with the thought the leak had self-healed. The tank was gradually refilled with no indication of leakage and the tank was considered operational. On January 28, 1965, tank A-105 experienced a rapid pressurization event that resulted in the tank liner bulging upward $81 / 2$-ft; radioactivity was detected one month later in a small area in a lateral on the north edge of the tank. Subsequent visual inspection showed that the bottom liner had separated from the wall liner around $75 \%$ of the tank's perimeter. There was no change in liquid level after the event and the tank continued to store waste until February 1968 when tank A-105 was declared a confirmed leaker. Supernatant was then transferred to tank A-103 and sluicing campaigns were initiated to remove the tank solids. Sluicing resulted in radioactivity being detected in previous and new locations. 
There are several liner leak cause conditions that were examined but the most likely cause of a tank A-104 or tank A-105 leak were the thermal conditions and problematic liquid level control in tank A-105. Also, the tank design associated with the orthogonal intersection between the liner bottom and wall did not allow for the thermal conditions encountered. In addition, there is the possibility of corrosion with the initial water cover in both tanks but especially tank A-105 which contained up to 18-in of water for seven years. The storage of PUREX sludge supernatant waste may have increased the propensity for stress corrosion cracking in tank A-104. Cold temperatures experienced during A Farm construction present the possibility of impact loading of the steel (e.g. a dropped tool or piece of equipment from scaffolding) which had the potential for creating micro-fissures in the steel liner. Some or all of the factors can act serially or together to contribute to tank liner failure. 


\section{RPP-RPT-54912, Rev. 0}

\section{TABLE OF CONTENTS}

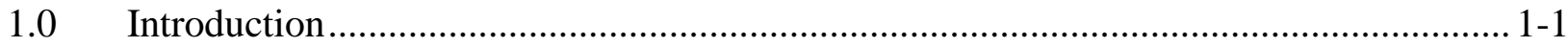

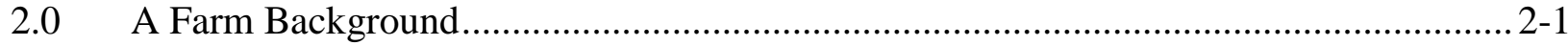

3.0 A Farm Commonalities ............................................................................. 3-1

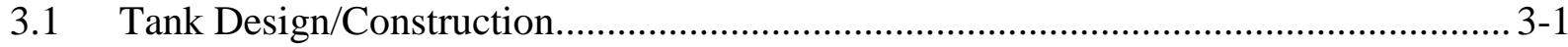

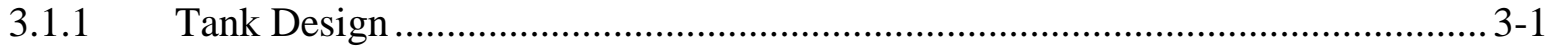

3.1.2 Tank Construction Conditions ......................................................................... 3-4

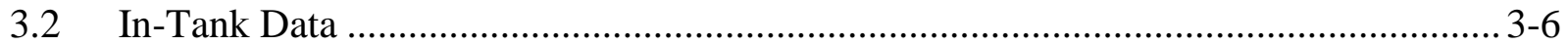

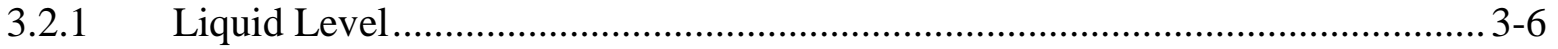

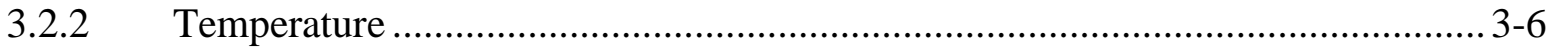

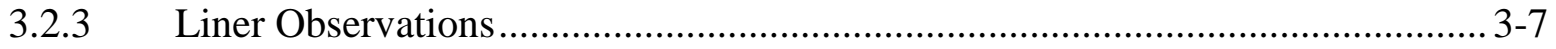

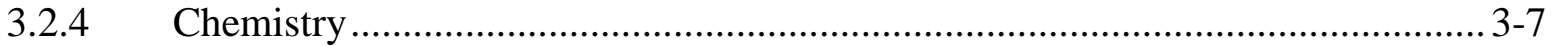

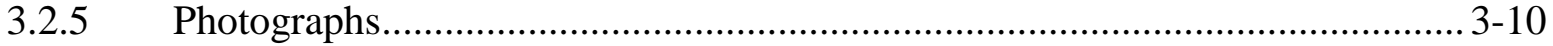

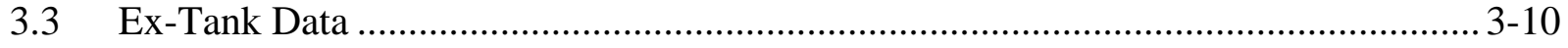

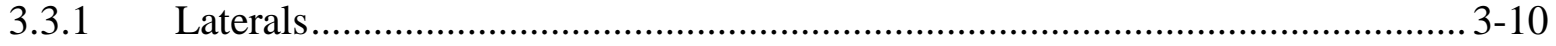

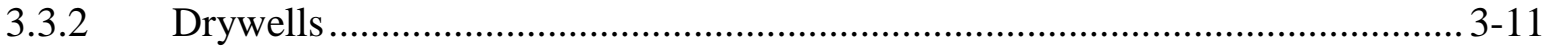

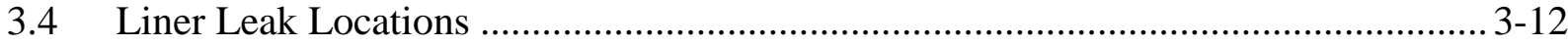

3.5 Possible Liner Leak Cause(s) ........................................................................ 3-13

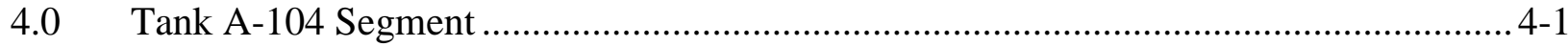

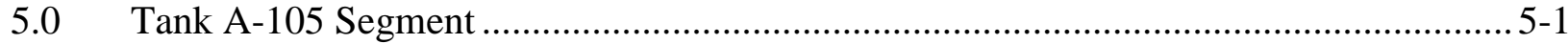

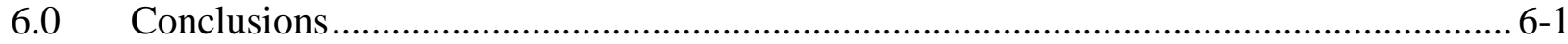

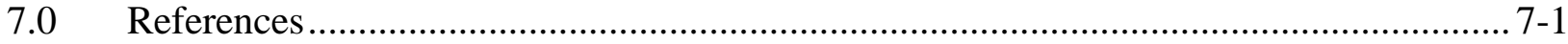

\section{APPENDICES}

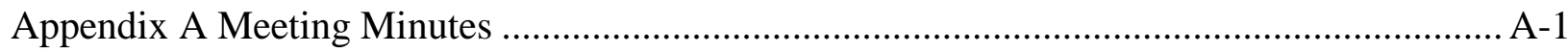




\section{RPP-RPT-54912, Rev. 0}

\section{LIST OF FIGURES}

Figure 2-1. A Farm Leaking Tanks with Laterals and Drywells ........................................ 2-1

Figure 3-1. A Farm Tanks Base Footing and Wall Reinforcing ........................................... 3-1

Figure 3-2. A Farm Tanks Bottom Liner to Sidewall Design Detail .................................... 3-2

Figure 3-3. 241-BCTU Farm Tanks Knuckle Configuration with Three Ply Waterproofing (BPF-73550, Drawing D-2 and D-3)................................................................ 3-3

Figure 3-4. A Farm Construction Photograph August 30, 1954 (Photograph \#N1D0057755) .. 3-5

\section{LIST OF TABLES}

Table 2-1. Leaking A Farm Tanks with Waste Type...................................................... 2-2

Table 3-1. Basic Fillet and Butt Weld Differences.......................................................... 3-3

Table 3-2. ARH-1601 Specifications 1973 ….................................................................... 3-9

Table 6-1. A Farm Leaking Tanks ................................................................................ 6-3

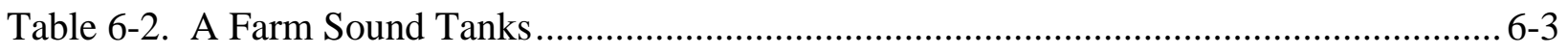


RPP-RPT-54912, Rev. 0

\author{
Abbreviations and Acronyms \\ 241-A \\ 241-A Tank Farm \\ ALC(s) \\ ARHCO \\ ASME \\ ASTM \\ BGS \\ BPF \\ $\mathrm{B} \& \mathrm{PVC}$ \\ $\mathrm{c} / \mathrm{m}, \mathrm{cpm}$ \\ $\mathrm{c} / \mathrm{s}, \mathrm{cps}$ \\ DOE \\ DST(s) \\ Ecology \\ GM \\ GMP \\ $\mathrm{H}_{2} \mathrm{SO}_{4}$ \\ HLW \\ LL \\ MDL \\ $\mathrm{NaI}$ \\ $\mathrm{NO}_{2}^{-}$ \\ $\mathrm{NO}_{3}{ }^{-}$ \\ $\mathrm{OCP}$ \\ $\mathrm{OH}^{-}$ \\ ORP \\ PCSACS \\ PUREX \\ SCC \\ SGLS \\ SP \\ SRS \\ SSP \\ SST(s) \\ WRPS \\ A \\ A Farm \\ air lift circulator(s) \\ Atlantic Richfield Hanford Company \\ American Society of Mechanical Engineers \\ American Society for Testing and Materials \\ below grade surface \\ Blueprint File \\ Boiler \& Pressure Vessel Code \\ counts per minute \\ counts per second \\ Department of Energy \\ double-shell tank(s) \\ State of Washington, Department of Ecology \\ gamma \\ gamma probe \\ sulfuric acid \\ high level waste \\ liquid level \\ minimum detection limit \\ sodium-iodide \\ nitrite \\ nitrate \\ open circuit potential \\ hydroxide \\ Office of River Protection \\ PC Surveillance Analysis Computer System \\ Plutonium Uranium Extraction (fuels reprocessing) Plant \\ stress corrosion cracking \\ Spectral Gamma Logging System \\ scintillation probe \\ Savannah River Site \\ shielded scintillation probe \\ single-shell tank(s) \\ Washington River Protection Solutions, LLC
}

\title{
Units
}

BTU

$\mathrm{Ci}$

${ }^{\circ} \mathrm{F}$

$\mathrm{ft}$

gal

$\mathrm{hr}$

K
British thermal unit

curie

degrees Fahrenheit

feet

gallon

hour

1000 
RPP-RPT-54912, Rev. 0

$\begin{array}{ll}\text { kgal } & \text { kilogallon }\left(10^{3} \text { gallons }\right) \\ \text { in } & \text { inches } \\ \mathrm{L} & \text { liter } \\ \mathrm{M} & \text { moles per liter } \\ \mathrm{mR} & \text { millirem } \\ \mathrm{mil} & \text { millimeter } \\ \mathrm{pCi} & \text { picocurie }\left(10^{-12} \text { curies }\right) \\ \mathrm{pCi} / \mathrm{g} & \text { picocurie per gram } \\ \mathrm{ppm} & \text { parts per million } \\ \mathrm{psi} & \text { pounds per square inch } \\ \mathrm{yr} & \text { year }\end{array}$

Waste Type Abbreviations

$\begin{array}{ll}\text { AR } & \text { 244-AR Vault waste } \\ \text { B } & \text { 221-B Plant strontium solvent extraction waste } \\ \text { PUREX HLW } & \text { PUREX high-level waste } \\ \text { OWW } & \text { PUREX organic wash waste } \\ \text { P or P1 } & \text { PUREX HLW supernatant } \\ \text { PSS } & \text { PUREX sludge supernatant }\end{array}$


RPP-RPT-54912, Rev. 0

\subsection{INTRODUCTION}

The Hanford Federal Facility Agreement and Consent Order target M-045-91F-T04 indicated that part of the RPP-32681, Process to Assess Tank Farm Leaks in Support of Retrieval and Closure Planning, reporting would include leak causes and locations reports for all of the 100-series single-shell leaking tanks. This document is part of a series of documents that identifies leak causes and locations of 100-series single-shell leaking tanks that have been identified in the individual RPP-32681 tank farm leak assessments. An overall leak causes and locations summary and conclusions document will be prepared along with background and common tank farm information when all of the 100-series single-shell leaking tanks have been addressed (RPP-RPT-54909, Hanford Single-Shell Tank Leak Causes and Locations -Summary and Conclusion, to be issued). The information from RPP-RPT-54909 will be incorporated into the summary conclusions report on leak integrity for the Hanford Federal Facility Agreement and Consent Order milestone M-045-91F.

The 241-A Tank Farm (A Farm) tanks with leak losses are addressed in this document on an individual tank basis. The A Farm assessment in RPP-ENV-37956 (Hanford A and AX Farm Leak Assessment Report) reported leak losses for the 241-A-104 (tank A-104) and 241-A-105 (tank A-105) tanks and recommended that 241-A-103 (tank A-103) tank be re-assessed using TFC-ENG-CHEM-D-42, Rev B-2 (Tank Leak Assessment Process). The re-assessment of tank A-103 using TFC-ENG-CHEM-D-42, Rev B-2, resulted in the recommendation that the tank integrity status be change from "Assumed Leaker" to "Sound Tank" (RPP-ASMT-42278, Tank 241-A-103 Leak Assessment Report).

The identification of A Farm tank leak locations relied on the first indication of radiation detected in laterals and drywells as well as liquid level decreases as appropriate. Tank A-105 experienced a steam eruption that resulted in an $81 / 2-\mathrm{ft}$ bulge of the tank bottom and separation of the tank bottom from the wall liner around $75 \%$ of the tank's perimeter.

The A Farm leak causes were identified as tank design, liner bulging, thermal conditions and possibly chemistry-corrosion, and tank construction conditions.

Two meetings were held to review status of tanks A-104 and A-105 with the Office of River Protection (ORP) and the State of Washington, Department of Ecology (Ecology) personnel. A review on December 3,2012, provided a summary of previous leak causes and locations documents, future projections and covered the information that had been generated on the tank A-105 leak locations and causes. A second meeting on January 15, 2013, provided a review of the tank A-104 leak causes and locations along with a comparison of the available information on the other A Farm tanks. Comments were received, responses developed, and additions/revisions were made to the document (see Appendix A). 


\subsection{A FARM BACKGROUND}

The A Farm is comprised of six Single-Shell Tanks (SSTs) boiling waste tanks built during 1954-1955. The tanks are arranged in two rows of three, forming a cascade. Each of the A Farm tanks has a nominal 1,000,000 gallon capacity. The A Farm tanks consist of a carbon steel liner inside a reinforced concrete shell. The concrete shell is a domed structure approximately 46.5-ft in height at the apex and $\sim 83$-ft in diameter at the footings. The steel tank liner covers the $75-\mathrm{ft}$ inner diameter tank bottom and sidewalls to a height of $\sim 32-\mathrm{ft}$ as measured from the tank center. The flat tank bottom connects orthogonally to the sidewall. Each tank was originally equipped with 9 to 11 risers, a 20-in diameter vapor exhaust pipeline that penetrated the tank dome, and four airlift circulators that were operated to suspend solids, mix the tank contents, and dissipate heat.

Figure 2-1 shows a schematic of the A Farm tanks with location of the laterals and drywells.

Figure 2-1. A Farm Leaking Tanks with Laterals and Drywells

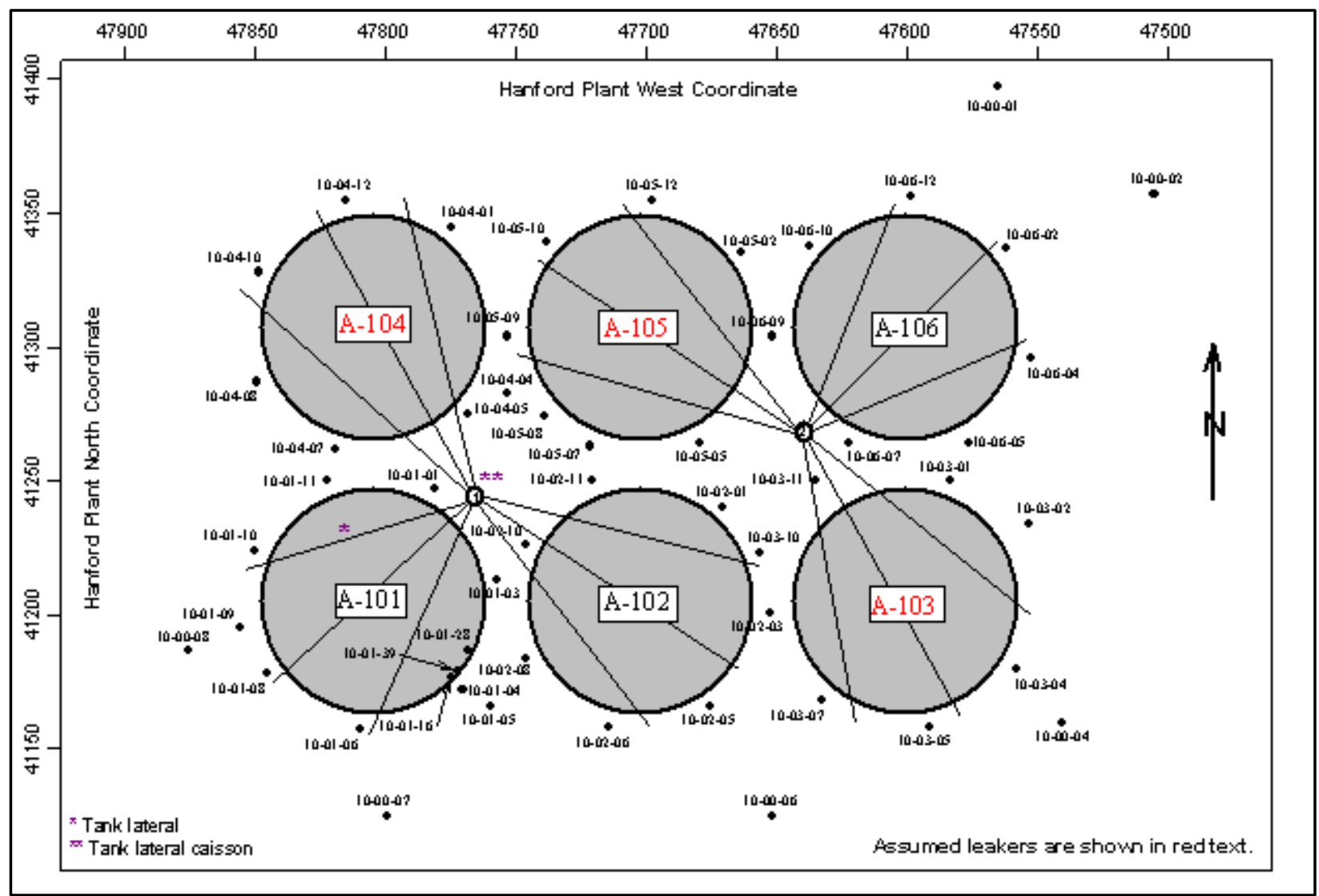

Note: The individual assessment of tank A-103 using TFC-ENG-CHEM-D-42, Rev B-2, resulted in the recommendation that the tank integrity status be change from "Assumed Leaker" to "Sound Tank" (RPP-ASMT-42278, Tank 241-A-103 Leak Assessment Report). 
Tanks A-104 and A-105 contained various waste types throughout operation which are listed in Table 2-1. The following sections describe some of the important common tank features and conditions that could affect tank leak location and cause. Affected tanks are noted where the features and conditions do not apply to all. This is followed by an A Farm tank by tank analysis of the possible leak causes and locations for each of the leaking tanks. The sections contain excerpts from RPP-ENV-37956.

Table 2-1. Leaking A Farm Tanks with Waste Type

\begin{tabular}{|c|l|}
\hline Tank & \multicolumn{1}{|c|}{ Waste Type $^{1}$} \\
\hline A-104 & B, AR, P1, PSS, OWW \\
\hline A-105 & PUREX HLW \\
\hline
\end{tabular}

1. Waste types are listed in the Waste Type Abbreviations, page vi. 
RPP-RPT-54912, Rev. 0

\subsection{A FARM COMMONALITIES}

\subsection{TANK DESIGN/CONSTRUCTION}

\subsubsection{Tank Design}

The A Farm tanks had multiple design features that could contribute to stresses or possible leak paths when the tank was being operated including:

- Orthogonal intersection between the flat steel bottom and the sidewall

- Fillet weld used between the bottom and sidewall intersection

- Less rigorous weld inspection testing

- Partial asphaltic membrane waterproofing

These features are common to all A Farm tanks.

The steel bottom of the A Farm tanks intersects the sidewalls orthogonally similar to 241-SX Farm tanks rather than the knuckle transitions in earlier designed tank farms (BPF-73550, Drawings D-2 and D-3, Specification for Construction of Composite Storage Tanks (B, C, T, and $U$ Tank Farms)). The A Farm tank footing and sidewall construction joint is shown on Figure 3-1 (H-2-55912, Base Footing and Wall Reinforcing, Purex Waste Disposal Facility). This figure shows the 7-in water stop at the base footing to wall construction joint and other details. The earlier 241-BCTU Farm tanks notched footing construction joint does not incorporate a water stop. There are no sidewall construction joints shown on H-2-55912 which is a departure from the five sidewall construction joints for the 241-SX Farm tanks (H-2-39512, 75 FT. Tank Base Footing and Wall Reinforcing, Waste Disposal Facility, 241-SX). The 6-in thick flat bottom A Farm tanks also differ from the 3.3\% sloped bottom of the 241-SX Farm tanks where the thickness near the center is $10 \%$-in including the liner, grout, and asphalt membrane.

Figure 3-1. A Farm Tanks Base Footing and Wall Reinforcing (Drawing H-2-55912)

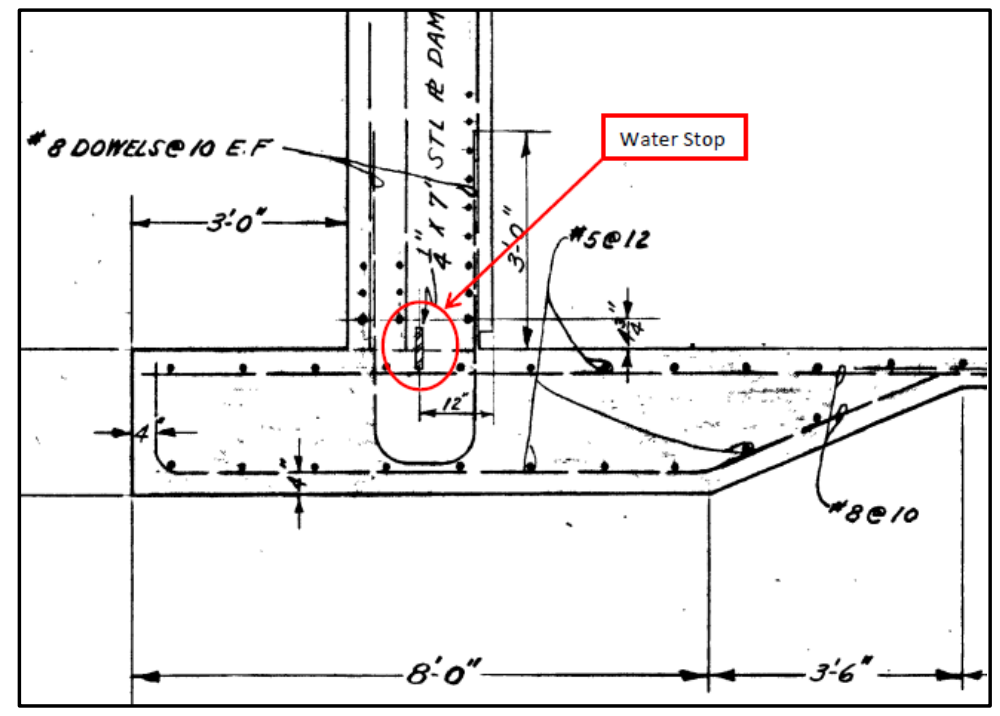


Figure 3-2 shows the detail of the orthogonal intersection between the bottom and the sidewall with a fillet weld between the bottom and sidewall orthogonal intersection (H-2-55911, Composite Section, Purex Waste Disposal Facility). Full penetration butt welds for 241-BCTU Farm tanks are shown on BPF-73550 (Drawings D-2 and D-3) for the rounded knuckle configuration shown in Figure 3-3.

The three ply asphaltic membrane waterproofing between the steel liner and the concrete shell was eliminated from the design of the A Farm tanks (see Figure 3-2). An asphaltic membrane was incorporated between the concrete footing and the grout below the liner. The design for 241-BCTU Farm tanks is shown in Figure 3-3 which shows the rounded knuckle configuration with the bottom, knuckle, and sidewall three ply waterproofing.

Other design specification changes for the A Farm tanks included the less rigorous weld testing with the Vacuum Soap Test at 10-in of mercury (HWS-5614, Specifications for Purex Waste Disposal Facility, Project CA-513-A). Spot X-Ray testing of the welds was specified for A Farm tanks per HWS-5614 at ten foot intervals at a minimum of 6-in. Spot X-Ray testing of the welds was specified for 241-SX Farm tanks per H-2-39511. Specifications required X-Ray of welds for 241-BCTU Farm tanks (BPF-73550).

Figure 3-2. A Farm Tanks Bottom Liner to Sidewall Design Detail (Drawing H-2-55911)

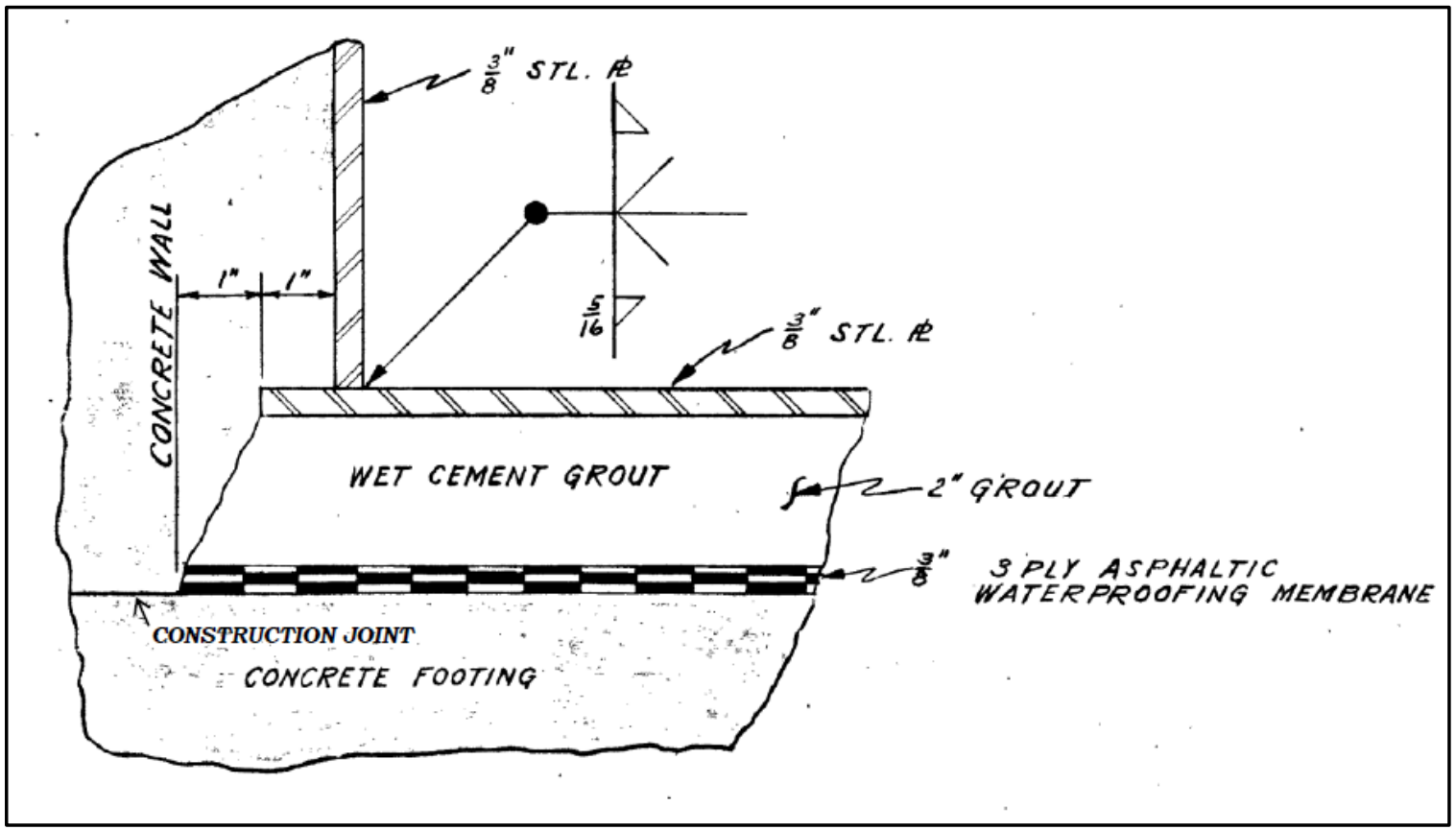

Note: The water stop at the construction joint between footing and middle of the concrete wall is to the left of the above detail. 
Figure 3-3. 241-BCTU Farm Tanks Knuckle Configuration with Three Ply Waterproofing (BPF-73550, Drawing D-2 and D-3)

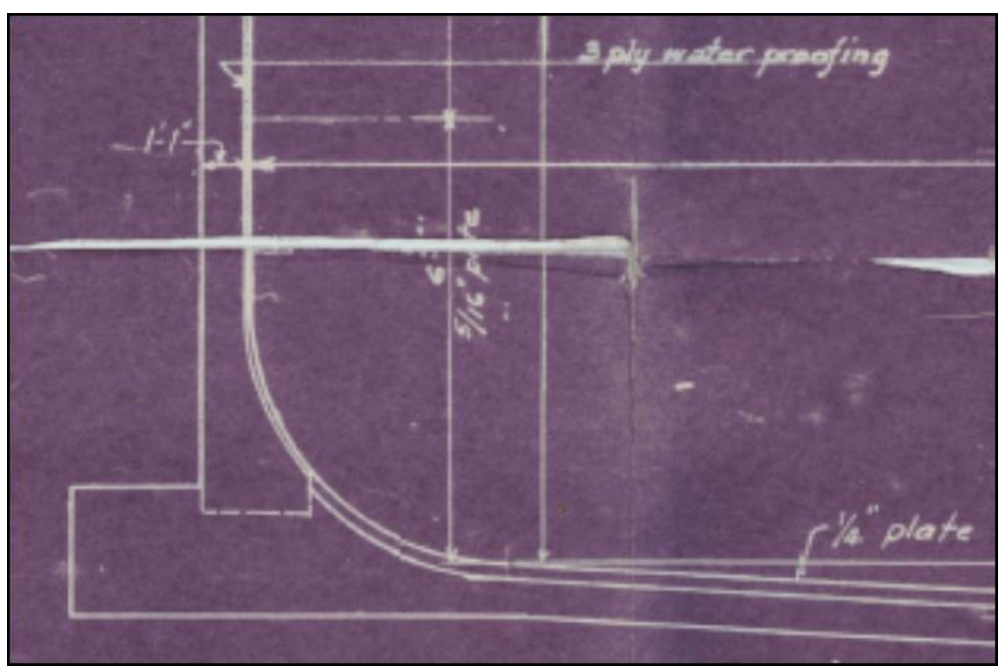

The design of the A Farm tanks was the second tank farm design after the 241-BCTU Farm tanks that diverged from the round bottom knuckle design used in the earlier waste tanks. A fillet weld was used to close the seam where the sidewall and tank bottom liners meet versus the butt welding of the knuckle transition of earlier tank designs. A review of the basic differences between fillet and butt welds indicates that the superior butt welds would be preferred for the tank farm waste tanks (see Table 3-1).

Table 3-1. Basic Fillet and Butt Weld Differences

Some excerpts from Steel Designer and Steel Construction Handbooks

\begin{tabular}{|c|c|c|}
\hline Attribute & Fillet Weld & Butt Weld \\
\hline Preparation Costs & Inexpensive & Expensive \\
\hline $\begin{array}{c}\text { Welding Speed } \\
\text { (Progress) }\end{array}$ & Fast & Slow \\
\hline Load Bearing & $\begin{array}{c}\text { Good for static loads } \\
\text { (structures) }\end{array}$ & $\begin{array}{c}\text { Good for dynamic loads } \\
\text { (pressure vessels) }\end{array}$ \\
\hline Quality & $\begin{array}{c}\text { Inferior resistance to fatigue } \\
\text { High potential for crack propagation } \\
\text { More distortion and stress buildup }\end{array}$ & $\begin{array}{c}\text { Greater resistance to fatigue } \\
\text { Weld is stronger than base metal } \\
\text { Minimal change in stress }\end{array}$ \\
\hline Inspection & $\begin{array}{c}\text { Harder to perform high quality } \\
\text { inspection (unable to radiograph) }\end{array}$ & $\begin{array}{c}\text { Easier to perform high quality } \\
\text { inspection (radiograph) }\end{array}$ \\
\hline
\end{tabular}

A review of literature to compare historical failure rates for fillet welds and butt welds did not identify any relevant information that could be related to the tank farm waste tanks. There was recognition that the base of the A Farm tanks was considered fixed and excessive steel stresses could be expected during pressure surges and elevated temperatures (LET-070357,

"Commentary Report for Structural Review and Cost Estimate of the Tank Designs," from H.W. Stivers addressed to J.B. Fecht, July 3, 1957). Tank farm experience indicates that several SSTs with fillet welds failed during service which was recognized by the Single-Shell Tank Integrity Expert Panel as a factor in future tank use (RPP-RPT-45921, Recommendation ST-2, Single 
Shell Tank Integrity Expert Panel Report).

The problem that the orthogonal joint design introduces including changes in asphaltic waterproofing is described in the following excerpt from HW-57274 (Instability of Steel Bottoms in Waste Storage Tanks):

"A steel liner which fits tightly inside a concrete shell provides no means for differential thermal expansion. Such expansion can result in high compressive stresses in the steel which may produce elastic instability. Instability is particularly likely to occur in the flat bottom of the liner resulting in rippling of the bottom. This is more apt to occur in designs in which the junction at the lower corner is 90 degrees as in the SX Tanks than in designs in which a radius is used as in the BX and TX Tanks of earlier design. Empty tanks in the SX farm have been observed to have rippled bottom liners before filling."

"A hydraulic head would tend to flatten the ripples but filling with hot waste would tend to increase the degree of rippling because of the restraint of the concrete shell. Under certain conditions this might cause rupture of a joint. The severity of the rippling is believed to have been demonstrated by the instability of the bottom of tank 113-SX after it was emptied. It is suggested that the restraint offered by the concrete shell be reduced by a return to the use of an asphalt expansion joint between the steel shell and the concrete shell."

The ripples identified in the preceding paragraphs probably refer to the visual effects of either the support structure for the bottom liner during construction or the overall stress inherent in the welding of multiple steel plates making up the bottom liner. Construction photographs were reviewed; however, no photographs were available to verify the presence of ripples in the tank bottom liner after hydrostatic testing. The small discontinuous ripples of probably less than a few inches in height observed during construction differ from bulging indicated in this report. Bulging is typically indicated by the degree of bottom liner uplift of more than several inches over a relatively larger area after the tank is being or has been filled.

Filling with hot waste could heat any water in the grout at the bottom of the tank or organics from the asphalt existing below the grout potentially trapping pressurized vapor (HW-57274). Several of the design changes lead to thermal expansion limiting characteristics which could result in forces that cause the liner to deform (bulge). The design of the orthogonal sidewall to bottom joint was postulated to trap the pressurized vapor under the liner because the liner edge was embedded in the structural concrete, preventing pressure release up the sidewalls. This in turn increased the temperature due to the lower vapor space heat transfer coefficient and decreased the heat transfer from the bottom of the tank which compounded the situation.

\subsubsection{Tank Construction Conditions}

The A Farm construction temperatures were examined to determine if the tank liner fabrication occurred at or below the metal ductile-to-brittle temperature transition. The photograph in Figure 3-4 shows the A Farm under construction on August 30, 1954. 


\section{Figure 3-4. A Farm Construction Photograph August 30, 1954 (Photograph \#N1D0057755)}

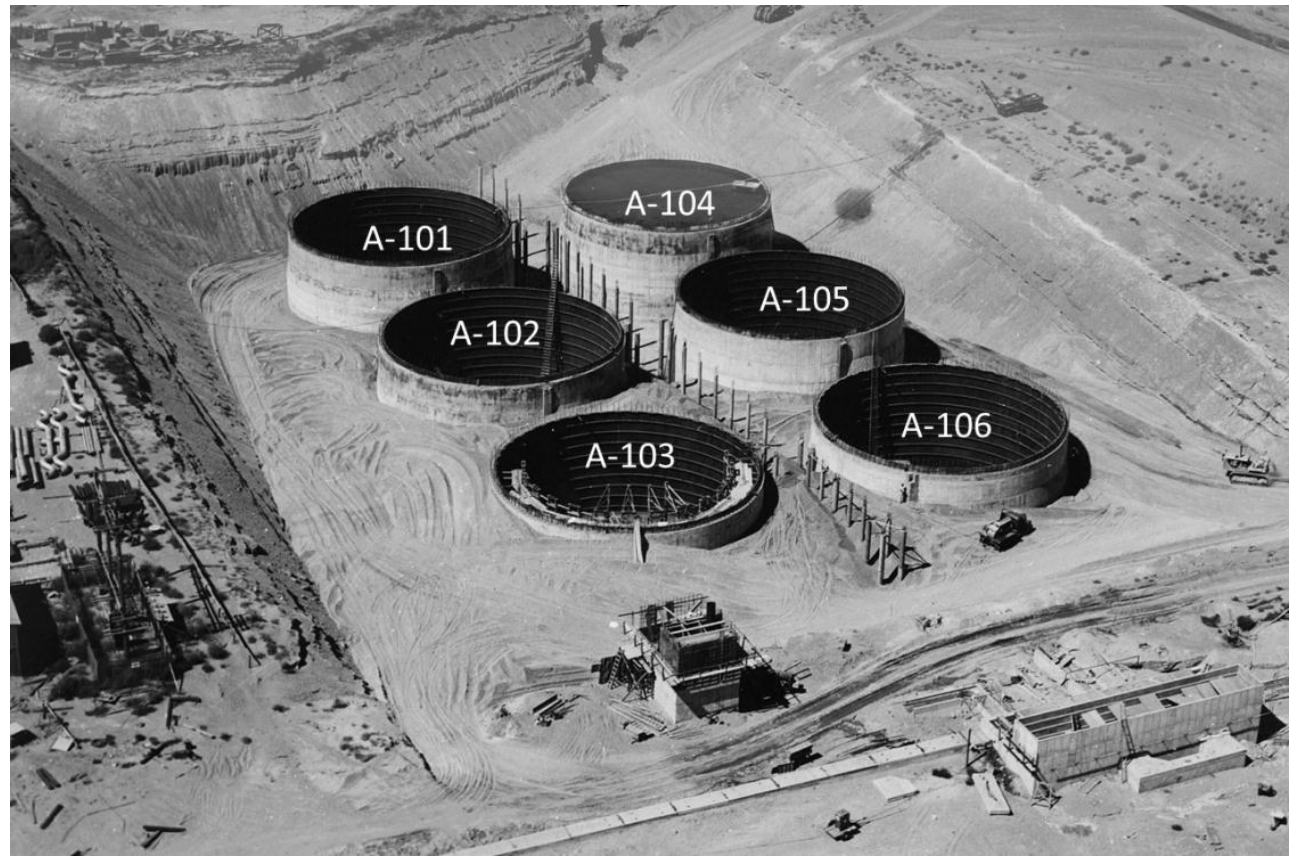

The metallurgical factors that limited carbon steel's ability to resist impact at low temperature were perhaps not well understood when A Farm was constructed and were not specified for the 0.375-in thick ASTM A 283, Standard Specifications for Intermediate Tensile Strength Carbon Steel Plates, mild carbon steel liner at the time. Current standards for construction of pressure vessels ASME Boiler \& Pressure Vessel Code (B\&PVC), Section VIII, Rules for Construction of Pressure Vessels, provides for a minimum design metal temperature of $18^{\circ} \mathrm{F}$ for vessels constructed of carbon and low alloy steels of nominal thickness $\leq 10-\mathrm{mm}(0.394$-in). For the purposes of this report, it will be assumed that the $18^{\circ} \mathrm{F}$ design temperature is applicable to the fabrication of ASTM A 283 carbon steel at the time of A Farm construction.

Boxes from the list of Vendor Information Reports for A Farm were searched for any Chemical and Physical Test Reports for the tank steel plates used in the farm but none were found. No other information for A Farm was found during the search.

A review of toughness and the ductile-to-brittle transition temperature for carbon steels (designated as "impact transition temperature") in Mark's Standard Handbook for Mechanical Engineers, Tenth Edition, indicates that carbon content can have a significant effect. Decreased carbon content not only raises the propagation energy needed for crack growth but also lowers the temperature for transition from ductile-to-brittle behavior (reference Fig 6.2.11 in Marks), suggesting that the B\&PVC Section III low temperature service limit may be lower than what could be expected for steel of the vintage used in A Farm construction. The concentrations of carbon and trace impurities and their effect on this property are not specifically known, and low temperature impact resistance could only be determined reliably by impact testing of actual tank specimens. 
Below the transition temperature, the metal loses its ability to absorb forces such as induced loads, or the impact of falling objects without fracturing. In this circumstance it is possible for micro-fissures or hairline cracks to be created. Later, when the metal is subjected to high stress, it might be possible for the cracks to propagate through the metal, or possibly subject the weakened areas to increased corrosion.

Any low temperatures experienced during construction at or less than the $18^{\circ} \mathrm{F}$ allowable temperature where impact loading (e.g. a dropped tool or piece of equipment from scaffolding) had the potential for creating micro-fissures may have triggered fissures in the steel liner (see Sections 4.3.2 and 5.3.2).

Design, fabrication, and erection of the tank steel lining were in accordance with Specification HWS-5614, Specifications for PUREX Waste Disposal Facility, Project CA-513-A. Welding and inspection requirements were listed in HWS-5614.

The possible variability of liner steel from either different runs from the same supplier, or because of multiple suppliers, could affect the resistance to low temperatures.

\subsection{IN-TANK DATA}

The general information in this section is further developed and applied to the leaking tanks in Sections 4.4 and 5.4 for tanks A-104 and A-105, respectively, to understand implications of the conditions that could affect liner leaks and identify possible liner leak locations.

\subsubsection{Liquid Level}

The leaking A Farm tanks (A-104 and A-105) did not experience liquid level decreases that were reported to be due to the tank leaking. Fluctuations in liquid level were reported for tank A-105 in September 1963 (prior to the pressurization event in January 1965), some increases as large as 12-in or $33 \mathrm{kgal}$. It is possible the tank bulged during this time as the supernatant was pumped out of the tank nine months earlier leaving the liquid level at 10-in setting up a differential between the grout vapor pressure and hydrostatic pressure. Liquid level data for tank A-104 was apparently not reviewed for a decrease when the tank was first suspected of leaking based on radioactivity being detected in the laterals as there was no mention in the documents reviewed.

\subsubsection{Temperature}

Document HW-59919 issued October 22, 1959 (Limitations for Existing Storage Tanks for Radioactive Wastes from Separations Plants) indicated that the self-boiling waste operating temperature should be maintained between $220^{\circ} \mathrm{F}$ and $250^{\circ} \mathrm{F}$. The maximum sludge temperature should not exceed $300^{\circ} \mathrm{F}$. Document HW-59919 contained the first boiling waste limitations on temperature. Thermal shock creates stress both from rapid temperature rise as well as high temperatures.

The same document states that tank contents should also be heated slowly to not exceed the recommended rate of $2^{\circ} \mathrm{F}$ per day along with other temperature requirements for filling boiling waste tanks. The filling temperature requirements upon initial filling with waste are designed to provide enough time at controlled temperature and other waste parameters (specific gravity and 
liquid depth) to remove grout moisture gradually so that the grout moisture vapor pressure does not exceed the hydrostatic pressure. Bulging of the tank bottom liner can be caused by exceeding the hydrostatic pressure. Initial rate of rise temperatures are not available in all cases.

Temperature data used for the A Farm evaluations were taken from RHO-CD-1172, Survey of the Single-Shell Tank Thermal Histories, and temperature data sheets and are designated as Bulb temperatures. The Bulb temperature nomenclature designation for sludge was first found in HW-83906-C-RD (Chemical Processing Dept 200 W Area Tank Farm Inventory \& Waste Reports 01/1957 Thru 12/1958, page 000126) as an annotation on the Status of Waste Farms form for February 1958. This was stated as " $\mathrm{S}=$ Bulb Temp of Sludge @ 2" off bottom." The liquid temperature was stated as "L=Liquid Temp @ $5 \mathrm{ft}$ off bottom." There was another annotation in HW-83906-C-RD (page 000185) that indicated the sludge temperature was designated as "Bulb" and the liquid temperature was designated as "SCAN". Typed in at the bottom of this page was the following: $\mathrm{S}$ - Temperature of sludge approximately 3-in off of the tank bottom and L - Temperature of liquid approximately 5-ft off of the tank bottom. However, the bulb temperature design and the degree of data uncertainty are unclear as no documentation for this information has been located.

\subsubsection{Liner Observations}

A bulge in a tank liner may result in the direct failure of the liner or cause enough stress or thinning on the steel liner plates and welds that they become more susceptible to the effects of corrosion. Experience indicates that bulging tends to be a dynamic phenomenon, and it is possible that a tank with no measured bulge at one point in time may actually have had a displaced liner that was not detected at another time. Multiple flexing of the tank liner as a bulge forms and returns to normal may set up stresses that even though the liner does not reach the elastic limits could result in a location that are more susceptible to corrosion.

RHO-R-39, Boiling Waste Tank Farm Operational History, and ARH-R-43, Management of Radioactive Wastes Stored in Underground Tanks at Hanford, contain tables that list the A Farm tanks that were inspected for a bulge as well as the tanks where a liner bulge was confirmed.

Tank A-105 may have experienced a bulge in 1963 before the 1965 steam eruption. A bulge of the tank bottom liner may have set up conditions that resulted in the 1965 steam eruption (see tank A-105 section).

A possible indicator of a bulge may be broken air lift circulator (ALC) turnbuckle guy rods and/or bent piping which can be seen in some photographs (see Section 3.2.5).

\subsubsection{Chemistry}

The types of corrosion that may occur in the Hanford Site SSTs include uniform corrosion, stress corrosion cracking (SCC), pitting, crevice, and liquid-air interface corrosion which were identified in HNF-3018, Single-Shell Tank Sluicing History and Failure Frequency.

Uniform corrosion rates for SSTs are reported to be generally less than 1 mil/year (HNF-3018)

for the SSTs. Carbon steel exposed to alkaline solutions has a low general corrosion rate (PNL5488, Prediction Equations for Corrosion Rates of A-537 and A-516 Steels in Double-Shell 
Flurry, Future Purex, and Hanford Facilities Wastes). However, the presence of the nitrate ion may induce various forms of localized attack (i.e., SCC, pitting, etc.).

\section{Nitrate Ion-Induced Stress Corrosion Cracking}

Stress corrosion cracking is the growth of cracks in a corrosive environment. It can lead to unexpected sudden failure of normally ductile metals subjected to a tensile stress, especially at elevated temperatures. Stress corrosion cracking is highly chemically specific in that certain alloys are likely to undergo SCC only when exposed to a small number of chemical environments. The chemical environment that causes SCC for a given alloy is often one which is only mildly corrosive to the metal otherwise.

Nitrate ion-induced SCC is the predominant threat to the integrity of the steel liners in the SSTs and double-shell tanks (DSTs) at the Hanford Site and many investigations have been performed to establish the parameters under which the tanks can be protected from this threat. This work, together with the efforts of many others, led to the adoption of the waste chemistry control limits for SCC prevention in 1983 (OSD-T-151-00017, Operating Specifications for the Aging Waste Operations in Tank Farms 241-AY and 241-AZ).

The factors governing the rates of nitrate ion-induced SCC cracking by Hanford Site DST wastes were recently reviewed (RPP-RPT-47337, Specifications for the Minimization of the Stress Corrosion Cracking Threat in Double-Shell Tank Wastes). In brief, the test results led to the conclusion that the rates of nitrate ion-induced SCC depended on the properties of the steel, the applied potential versus the open circuit potential (OCP), the temperature and the concentrations of aggressive substances such as nitrate ion, and the potential inhibitors such as hydroxide and nitrite ion.

The technical work has shown that SCC is promoted by high temperatures, high nitrate ion concentrations, low hydroxide ion concentrations, low nitrite ion concentrations, and low nitrite ion/nitrate ion concentration ratios. Tanks with maximum temperatures less than $122^{\circ} \mathrm{F}$ would not be expected to experience significant SCC damage regardless of waste types (HNF-3018, Rev. 0). Tanks with the maximum temperatures above $122^{\circ} \mathrm{F}$ and a ratio of nitrate concentration to the sum of nitrite and hydroxide concentrations greater than 2.5 would be expected to suffer SCC-related damage (HNF-3018, Rev. 0). The concentration of nitrate and temperature are parameters that have the most effect on SCC. However, the $\mathrm{pH}$ (hydroxide) and nitrite can inhibit SCC. The current DST operating specifications for chemistry are reported in OSD-T151-00007, Rev. 10, Operating Specifications for the Double-Shell Storage Tanks. While the chemistry specifications stated in this document were prepared for the DSTs, corrosion mechanisms and corrosion protection mechanisms applicable to DST primary tank metal liners are equally applicable to the older SST metal liners.

\section{Localized Corrosion: Crevice, Pitting, and Liquid-Air Interface Corrosion}

Crevice corrosion can occur in regions where a small volume of solution cannot readily mix with the bulk solution such as under deposits, between metal flanges, and other confined areas. Once initiated, crevice corrosion proceeds by the same mechanism as pitting corrosion (RPP-RPT33306, IQRPE Integrity Assessment Report for the 242-A Evaporator Tank System). 
Pitting corrosion is the localized corrosion of a metal surface confined to a point or small area that takes the form of cavities. Pitting corrosion in dilute solutions $\left(\mathrm{NO}_{3}{ }^{-}<1 \mathrm{M}\right)$ of waste has been studied at the Savannah River Site (SRS). Pitting has been determined to not be a problem at hydroxide concentrations greater than 1M for any of the dilute waste solutions tested (WSRCTR-90-512, Effect of Temperature on the Nitrite Requirement to Inhibit Washed Sludge, Oblath and Congdon 1987, Inhibiting Localized Corrosion during Storage of Dilute Waste). Nitrate ion was determined to be the usual controlling aggressive species when its concentrations ranged between 0.01M and 1M (WSRC-TR-90-512). The presence of hydroxide ion and nitrite ion has shown to inhibit pitting corrosion due to the aggressive nitrate ion. This work led to the conservative recommendation that the concentration of nitrite ion be greater than $0.033 \mathrm{M}$ for the avoidance of pitting in dilute solutions of nitrate ion at $\mathrm{pH} 10$ and $40^{\circ} \mathrm{C}\left(104^{\circ} \mathrm{F}\right)$ (RPP-ASMT53793, Rev. 0, Tank 241-AY-102 Leak Assessment Report).

The chemical compositions required for prevention of pitting corrosion can also be applied as limits for prevention of liquid-air interface corrosion at the surface of the supernatant. Crevice, pitting, and liquid-air interface corrosion are types of localized corrosion possible in the SSTs; however, historically SCC is the more predominant type of corrosion of concern.

\section{Historical Corrosion Control}

The earliest chemical specifications for SSTs addressing $\mathrm{pH}$, nitrite, nitrate, and hydroxide are listed in Table 3-2 (ARH-1601, Section D, Specifications and Standards for the Operation of Radioactive Waste Tank Farms and Associated Facilities, 1973).

Table 3-2. ARH-1601 Specifications 1973

\begin{tabular}{|c|c|}
\hline \multicolumn{2}{|c|}{ Waste Tank Farms and Associated Facilities Specifications } \\
\hline Variable & Specification \\
\hline $\mathrm{pH}$ & Minimum 8.0 \\
\hline $\mathrm{NO}_{2}^{-}$ & $500 \mathrm{ppm}$ \\
\hline $\mathrm{NO}_{3}^{-}$ & $<6 \mathrm{M}$ \\
\hline $\mathrm{OH}^{-}$ & $<7 \mathrm{M}$ \\
\hline
\end{tabular}

There was no similar specification found that addressed all of these parameters during the operation of A Farm prior to 1973. If the ARH-1601 specifications were in effect during A Farm waste storage, the storage of undesirable concentrations of $\mathrm{NO}_{2}{ }^{-}, \mathrm{NO}_{3}{ }^{-}$, and $\mathrm{OH}^{-}$would result in vulnerability to SCC and/or localized corrosion.

Historical waste sample data as well as temperatures are typically not available for the SSTs and limited data were recovered for tanks A-104 and A-105. Thus, the concentrations of $\mathrm{NO}_{2}{ }^{-}, \mathrm{NO}_{3}{ }^{-}$, and $\mathrm{OH}^{-}$listed in Sections 4.4.4 and 5.4.4 are typical concentrations that were reported for the waste types listed that could be based on limited data and/or were values obtained from process flowsheets. Therefore, waste chemistry conditions are speculative when sample and temperature data are unavailable, and especially when multiple waste types are present in the tank. 
RPP-RPT-54912, Rev. 0

\subsubsection{Photographs}

Missing or disconnected ALC turnbuckle guy rods could indicate that there was bulging of the bottom liner sufficient to cause the upper connection to fail with the guy rod sinking below the liquid surface (missing). Each ALC was anchored to the tank floor by three one-half inch diameter guy rods. In several tanks, broken ALC turnbuckle guy rods and/or bent piping are visible. Some ALC turnbuckle guy rods were also hanging free from the upper connection as it had apparently become disconnected from the bottom connection either at the attachment plate or the plate itself pulled away from the bottom of the tank.

Photographs of tank A-105 taken after the steam eruption show bent ALCs and the raised bottom liner confirming the $8 \frac{1}{2}$-ft liner bulge. The torn liner can also be seen in photographs with the gap shown between the two torn steel pieces.

Both of the leaking tanks as well as some of the sound A Farm tanks contained ALCs that have one or more disconnected turnbuckle guy rods (see Section 6.0).

\subsection{EX-TANK DATA}

The general information in this section is further developed and applied to the leaking tanks in Sections 4.4 and 5.4 for tanks A-104 and A-105, respectively, to understand implications of the conditions that could affect liner leaks and identify possible liner leak locations.

\subsubsection{Laterals}

A prototype five lateral leak detection system was installed under tank SX-113 after indications of a >4-ft liner bulge in 1958. The tank SX-113 prototype laterals were installed 10-ft under the tank and varied between $6-\mathrm{ft}$ and $12-\mathrm{ft}$ below the bottom of the tank over the course of a lateral. The horizontal alignment was calculated to be within $~ 2-\mathrm{ft}$ (HW-60749, Leak Detection System for Active Tanks Interim Report). The alignment was addressed in HW-60749 and included the following: "The subcontractor was permitted to complete the five laterals to the best of his ability without official alignment checks because of the short time limit of the construction schedule." In addition, the document included future specifications to control alignment.

In 1963, lateral leak detection systems were installed underneath the six A Farm tanks. The scope and design criteria for drilling laterals were documented in HW-68661 (Proposed Leak Detection System for Existing Storage Tanks Containing Self-Boiling Radioactive Wastes (Scope and Design Criteria)). The driller was required to check the alignment of the laterals every 20-ft during the installation according to this document and it was assumed installation of the laterals were improved as no records of vertical or horizontal variation were found after the original tank SX-113 lateral installation.

Each lateral is a 3-in pneumatic stainless steel tubing enclosed in 4-in carbon steel pipe. The laterals are horizontal and extend radially from a large caisson (12-ft diameter) that is located between up to four tanks. A "lateral shack" was constructed over each caisson. The access to each lateral is through a separate vertical tube (also made of 3-in pneumatic stainless steel) that extends up to the floor of the lateral shack. The lateral tube transitions from vertical to horizontal at the bottom of the caisson through a $90^{\circ}$ elbow with a 4 -ft bend radius. The laterals 
are numbered clockwise from 1 to 3 . Probes are inserted into each lateral, driven to the end of the lateral with compressed air, and slowly withdrawn to monitor for gamma radiation that could indicate waste leakage from a tank. Operation of the laterals and details of the probes and data are described in RPP-RPT-27605, Gamma Surveys of the Single-Shell Tank Laterals for A and SX Tank Farms. The criteria for lateral monitoring frequency are defined in SD-WM-TI-356, Waste Storage Tank Status and Leak Detection Criteria.

Four temperature monitoring laterals were installed 2-ft under tank A-105 with thermocouples to measure the soil temperature near the base of the tank and readings were started in 1968 (see Section 5.4.2.1).

\subsubsection{Drywells}

Four of the original A Farm drywells were drilled in 1955. The remainder of the 48 A Farm drywells were drilled starting in 1962 (GJ-HAN-106 to 111). Drywells were drilled vertically from the surface drywell coordinates and detailed drywell information, e.g. pipe dimensions and configuration, for the leaking A Farm tanks are addressed in references sited in the individual tank segments. Three soil sampling test wells were drilled for specific leak determinations for tank A-105.

Drywells would not be useful to detect tank releases that enter the soil from the tank unless the volume released is sufficiently large to facilitate lateral transport to a drywell typically to within $\sim 1-\mathrm{ft}$ of the drywell. The vertical height of a tank liner leak may not be directly related to the point of detection in the drywell. This is especially true for small leaks that may flow downward some distance before encountering the drywell.

The "00" series drywells were installed between 1955 and 1969, usually around the periphery of the farm and extend from 150-ft to 340-ft BGS. Others with tank numbers embedded in the drywell number were constructed between 1962 and 1964 and generally to 100-ft BGS (or less). The usual number of drywells surrounding an A Farm tank was seven. If there are more, then there likely was some concern regarding a release which was being investigated.

Four gamma ray probe types were used to monitor gamma in drywells to detect leaks (RPP8820, Analysis and Summary Report of Historical Dry Well Gamma Logs for the 241-A Tank Farm-200 East Area). The most widely used probe was the unshielded gross gamma sodiumiodide (NaI) probe (or probe 04 ) and the shielded NaI probe is also referred to as probe 14 . The $\mathrm{NaI}$ probe (04) is very sensitive and able to record gamma ray activity from 30 counts per second (cps) up to about 40,000 cps $(15 \mathrm{mR} / \mathrm{hr})$ before the data becomes unreliable. The next most commonly used probe was the Red-GM (or probe 02) which is less sensitive but can reliably record gross gamma at much higher levels of activity (up to $\sim 500 \mathrm{R} / \mathrm{hr}$ ). Operation of these and other probes are discussed in HNF-3136. A scintillation probe (SP) was also used to measure low levels of radiation in the drywells; however, prior to June 1973 drywell readings less than $50,000 \mathrm{cpm}$ were reported as such. Leak location identification is primarily focused on the first indication of a leak and is therefore typically concerned with the lower levels of gross gamma detection. 
Drywell sections contain figures taken from RPP-8820, Analysis and Summary Report of Historical Dry Well Gamma Logs for the 241-A Tank Farm-200 East, showing continuing or new contamination in the drywells based on BGS depth from 1975 to 1995 . However, these figures do not indicate the amount of radioactivity found at these depths. In 1998, a baseline characterization of the gamma-ray-emitting radionuclides distributed in the vadose zone sediments beneath and around A Farm was performed using spectral gamma logs (SGLS) and documented in GJO-HAN-23 (Vadose Zone Characterization Project at the Hanford Tank Farms A Tank Farm Report). Individual vadose zone characterization summary data reports were issued in 1998 for the U Farm tanks with results reported in the leaking tank segments. The gross gamma detection sensitivity is higher than SGLS $(\sim 10 \mathrm{pCi} / \mathrm{g}$ versus $\sim 0.1 \mathrm{pCi} / \mathrm{g}$ equivalent Cs-137). Therefore, radioactivity $<10 \mathrm{pCi} / \mathrm{g}$ does not appear on the gross gamma figures (GJOHAN-18). Co-60 has a higher detection threshold; therefore, SGLS will detect Co-60 at much lower levels than what is detected by gross gamma logging. The SGLS logging can confirm both Cs-137 and/or Co-60 radioactivity which can assist in the leak location analysis, with the SGLS data weighted more heavily for interpreting drywells. The criteria for drywell monitoring are defined in RHO-ST-34 (A Scientific Basis for Establishing Drywell-Monitoring Frequencies) with the monitoring frequency found in SD-WM-TI-356 (Waste Storage Tank Status and Leak Detection Criteria).

All of the radiation readings in drywells are assumed to be maximum or peak readings unless otherwise noted and are from the Red-GM probe unless otherwise indicated. The individual tank segments report the available drywell data in the drywell sections. The drywell summary section provides the analyses of the associated drywells and any direct pushes associated with the tank that is of concern.

\subsection{LINER LEAK LOCATIONS}

Liquid level decreases, if detected, are typically the first indication of a tank liner leak in nonboiling tank conditions. Liquid level decreases are typically confirmed by drywell and/or lateral radioactivity. The radial drywell radioactivity is also dependent on any possible flow paths from the actual tank liner location to the drywell itself as well as the waste viscosity and distance to the drywell. Drywells can also be an indication of the tank liner sidewall leak depending on the vertical location but need to be analyzed relative to non-tank leaks associated with pipe lines or other sources.

A bottom liner leak detected by lateral or drywell radioactivity may have penetrated the waterproof membrane at any location or pooled on the waterproof membrane and followed concrete cracks or breaks in the footing to a different location including the top of the tank footing. Therefore, the point of waste egress from the tank liner may not be the point of entry of the leaking waste to the soil. Radioactivity detected in drywells is typically dependent on the leak path through the concrete sidewall or footing and soil conditions. Also, if the drywell radioactivity is detected above the footing there could be a possibility of a sidewall leak or leaks associated with pipe lines or other sources. If enough information is available, liquid level and drywell radioactivity can be used to locate the approximate vertical location of a liner leak. Lateral radioactivity almost always indicates a leak at or below the footing. 
The lack of radioactivity above background in a drywell indicates that if there was a liner leak it either occurred at another location, the leak flow was insufficient to be detected with the probes used in the drywell, or the leak was not able to be detected with the gamma probe. When there is no radioactivity detected in a drywell or no recoverable data for a drywell it is not included as part of the leak location analysis.

\subsection{POSSIBLE LINER LEAK CAUSE(S)}

Analysis which centered on tank design/construction, in-tank data, and ex-tank data indicates that there were up to five A Farm tank conditions that could contribute to a failed liner: tank design, liner bulging, thermal conditions, chemistry-corrosion, and tank construction conditions. Waste chemistry was not controlled to the degree necessary to minimize corrosion when tanks A-104 and A-105 were suspected of leaking. Some or all of the factors can act serially or together to contribute to tank liner failure. The following sections will provide a tank by tank review of these conditions as they relate to liner leak causes.

Other general tank construction factors such as the quality of materials and fabrication could also contribute to tank liner failure. No evidence has been found to substantiate quality defects but they still remain a possibility as a primary or secondary liner leak cause. 


\subsection{TANK A-104 SEGMENT}

\section{TABLE OF CONTENTS}

4.1 Tank A-104 Background History ....................................................................... 4-4

4.2 Tank A-104 Operations Summary ................................................................. 4-5

4.3 Tank Design/Construction..................................................................................

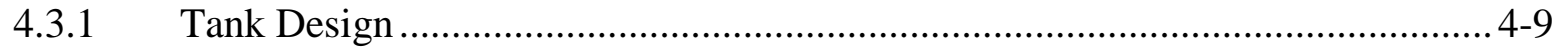

4.3.2 Tank Construction Conditions ....................................................................... 4-9

4.4 Tank A-104 In-Tank Data .................................................................................. 4-9

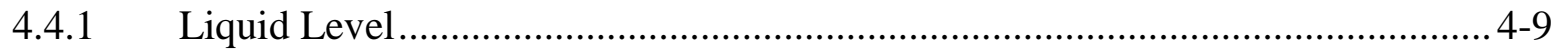

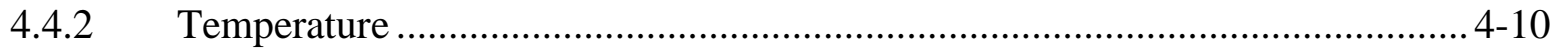

4.4.3 Liner Observations ......................................................................... 4-11

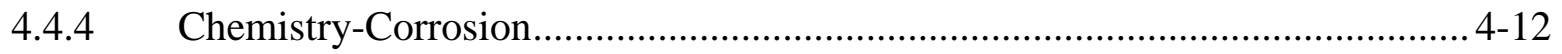

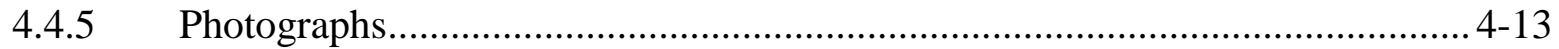

4.5 Tank A-104 Ex-Tank Data ................................................................................. 4-17

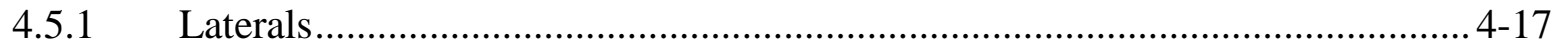

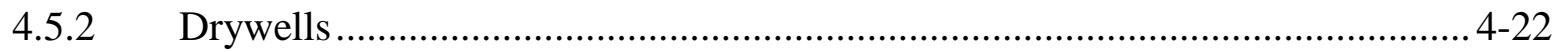

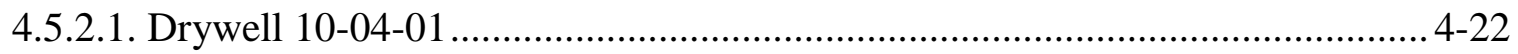

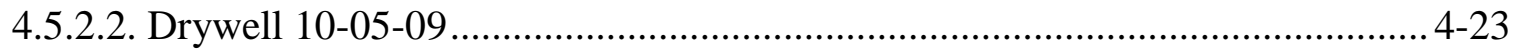

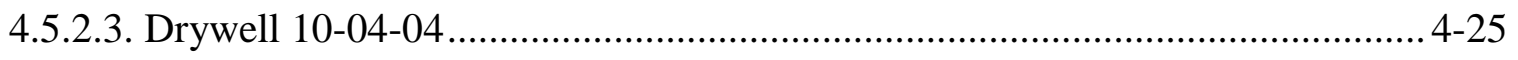

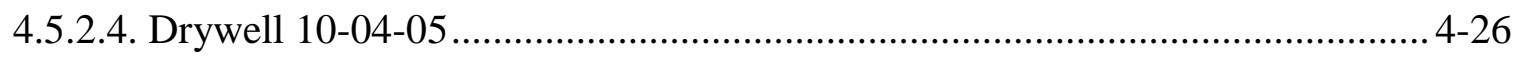

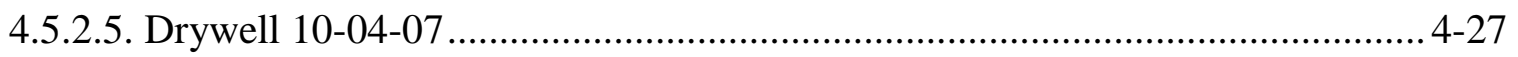

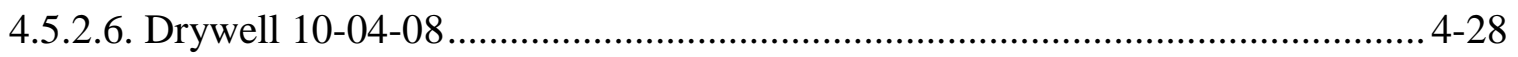

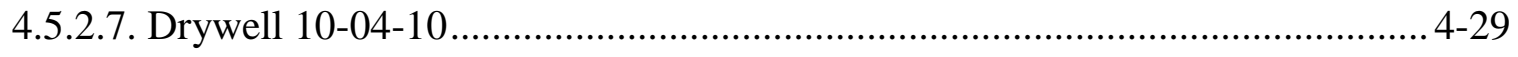

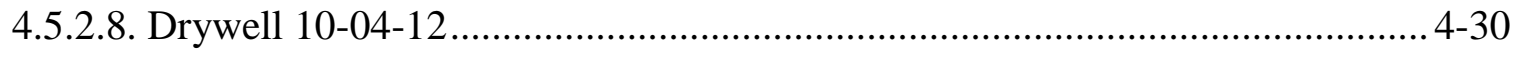

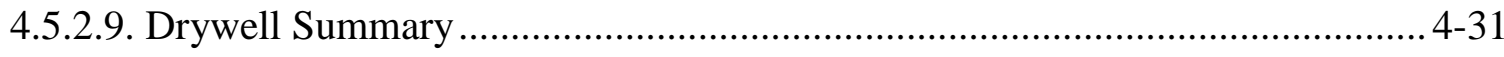

4.6 Possible Tank A-104 Liner Leak Location(s) .................................................... 4-31

4.6.1 Leak Detected in March 1975 ..................................................................... 4-32

4.6.2 Leak Detected in April 1975 ................................................................ 4-33

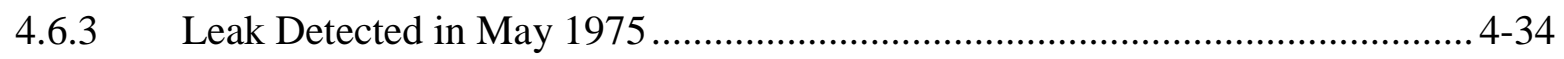

4.6.4 Leak Location Summary .................................................................... 4-35

4.7 Possible Tank A-104 Liner Leak Cause(s) ......................................................... 4-37

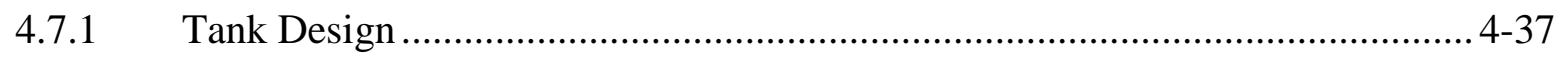

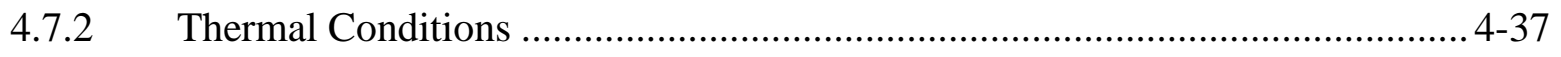




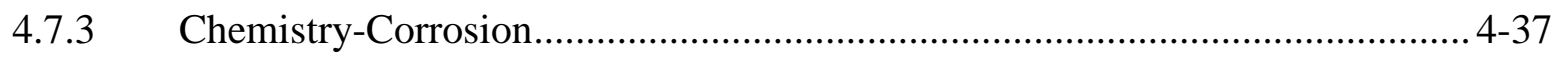

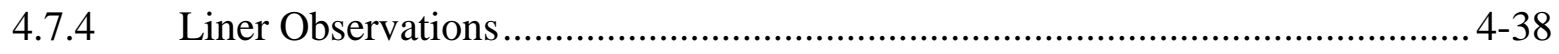

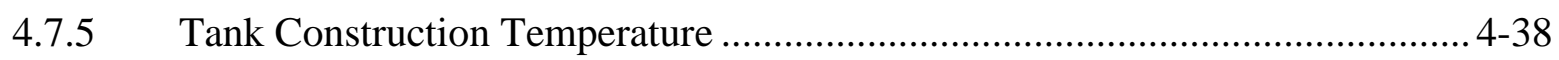

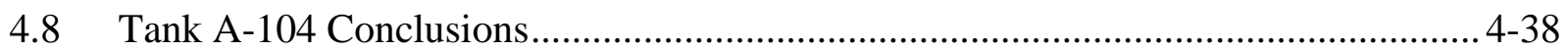

\begin{abstract}
APPENDICES
Appendix A1 Tank A-104 Boiling Waste Operational History ............................. A1-1

Appendix B1 Tank A-104 Temperatures December 1962-March 1970..................... B1-1

Appendix C1 Tank A-104 Lateral Activity................................................... $1-1$

Appendix D1 Tank A-104 Gross Gamma Drywell Data....................................D1-1
\end{abstract}

\title{
LIST OF FIGURES
}

Figure 4-1. Tank A-104 Associated Drywells and Laterals .................................................... 4-4

Figure 4-2. Operational Leak History of Tank A-104 …........................................................ 4-8

Figure 4-3. Tank A-104 End of Quarter Surface Level ........................................................ 4-10

Figure 4-4. Tank A-104 ALC \#1 Photograph 0694459-34 October 7, 1969............................ 4-14

Figure 4-5. Tank A-104 ALC \#2 Photograph 0694459-20 October 7, 1969........................... 4-15

Figure 4-6. Tank A-104 ALC \#3 Photograph 8604129-22CN June 25, 1986 .......................... 4-16

Figure 4-7. Tank A-104 ALC \#4 Photograph 8604129-24CN June 25, 1986.......................... 4-17

Figure 4-8. Tank A-104 Historical Lateral Radioactivity December 1975 (ARH-LD-120) .... 4-18

Figure 4-9. Tank A-104 Historical Lateral Surveys (counts per second) ................................. 4-19

Figure 4-10. Summary Gamma Survey for Lateral 14-04-01 on Logarithmic Scale ............... 4-20

Figure 4-11. Summary Gamma Survey for Lateral 14-04-02 on Logarithmic Scale ............... 4-21

Figure 4-12. Tank A-104 Drywell 10-04-01 (RPP-8820) ………………………………..... 4-23

Figure 4-13. Tank A-104 Drywell 10-05-09 (RPP-8820) ………………........................... 4-24

Figure 4-14. Tank A-104 Drywell 10-04-04 (RPP-8820) …………………………........... 4-25

Figure 4-15. Tank A-104 Drywell 10-04-05 (RPP-8820) …………………………............ 4-26

Figure 4-16. Tank A-104 Drywell 10-04-07 (RPP-8820) …………………….................... 4-27

Figure 4-17. Tank A-104 Drywell 10-04-08 (RPP-8820) ……………….............................. 4-28

Figure 4-18. Tank A-104 Drywell 10-04-10 (RPP-8820) …………………………............ 4-29

Figure 4-19. Tank A-104 Drywell 10-04-12 (RPP-8820) ………………………….............. 4-30 
Figure 4-20. Tank A-104 Possible Leak Location (March 1975)........................................ 4-32

Figure 4-21. Tank A-104 Leak Indication (April 1975) ................................................. 4-33

Figure 4-22. Tank A-104 Leak Indicators (May 1975) .................................................. 4-34

Figure 4-23. Tank A-104 Possible Radial Leak Locations and Indicators ............................ 4-36

Figure B1-1. RHO-CD-1172 Tank A-104 Temperature December 1962 through

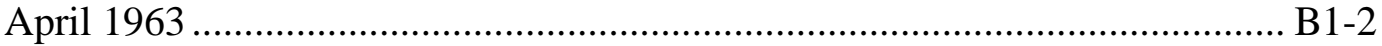

Figure B1-2. RHO-CD-1172 Tank A-104 Temperature May 1963 through

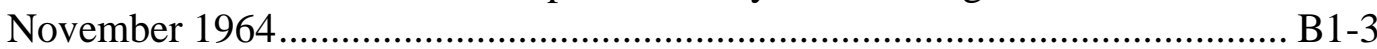

Figure B1-3. RHO-CD-1172 Tank A-104 Temperature December 1964 through

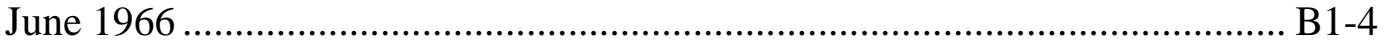

Figure B1-4. RHO-CD-1172 Tank A-104 Temperature July 1966 through January 1968 ..... B1-5

Figure B1-5. RHO-CD-1172 Tank A-104 Waste Temperature February 1968 through August 1969.......................................................................... B1-6

Figure B1-6. RHO-CD-1172 Tank A-104 Temperature September 1969 through March 1970 B1-6

\section{LIST OF TABLES}

Table 4-1. Tank A-104 Waste Storage Chronology …..................................................... 4-12

Table 4-2. Waste Chemistries for Waste Types Stored in Tank A-104............................... 4-12

Table A1-1. RHO-R-39 Boiling Waste Tank Operating Data Table....................................A1-2

Table C1-1. Tank 241-A-104 Lateral Radioactivity (K counts per minute) (July 1974 through June 1986) ..................................................................... C1-2

Table D1-1. Tank 241-A-104 Drywell Radioactivity (K counts per minute) (January 1965 to November 1986). 


\subsection{TANK A-104 BACKGROUND HISTORY}

This section provides information on the historical waste loss event associated with single-shell tank (SST) 241-A-104 (A-104). Tank A-104 has three laterals installed in 1962-1963 about 10-ft under the tank (see Figure 4-1). There are eight drywells located around tank A-104 with specified distances from the drywell to the tank footing shown in Figure 4-1: 10-04-04 installed in May 1955 and 10-04-01, 10-05-09, 10-04-05, 10-04-07, 10-04-08, 10-04-10, and 10-04-12 installed in April/May 1962.

The bottom of the tank footing is $\sim 47$-ft 10-in Below Grade Surface (BGS) with $~ 7.5$-ft soil cover over the dome (WHC-SD-WM-TI-665, Soil Load above Hanford Waste Storage Tanks; H2-55911, Waste Storage Tanks Composite Section). Inside tank A-104 are four air lift circulators (ALC) terminating 18-in above the tank bottom and equally spaced on a 40 -ft diameter circle as shown in Figure 4-1 (H-2-56350, Arrangement Air-Lift Circulators). Two ALCs are designated low ALCs (8-ft 6-in tall) and two are high ALCs (17-ft 6-in tall) (H-2-56342, Details Air-Lift Circulator).

Figure 4-1. Tank A-104 Associated Drywells and Laterals

Tank inner ring is steel liner; outer ring is outer edge of tank footing

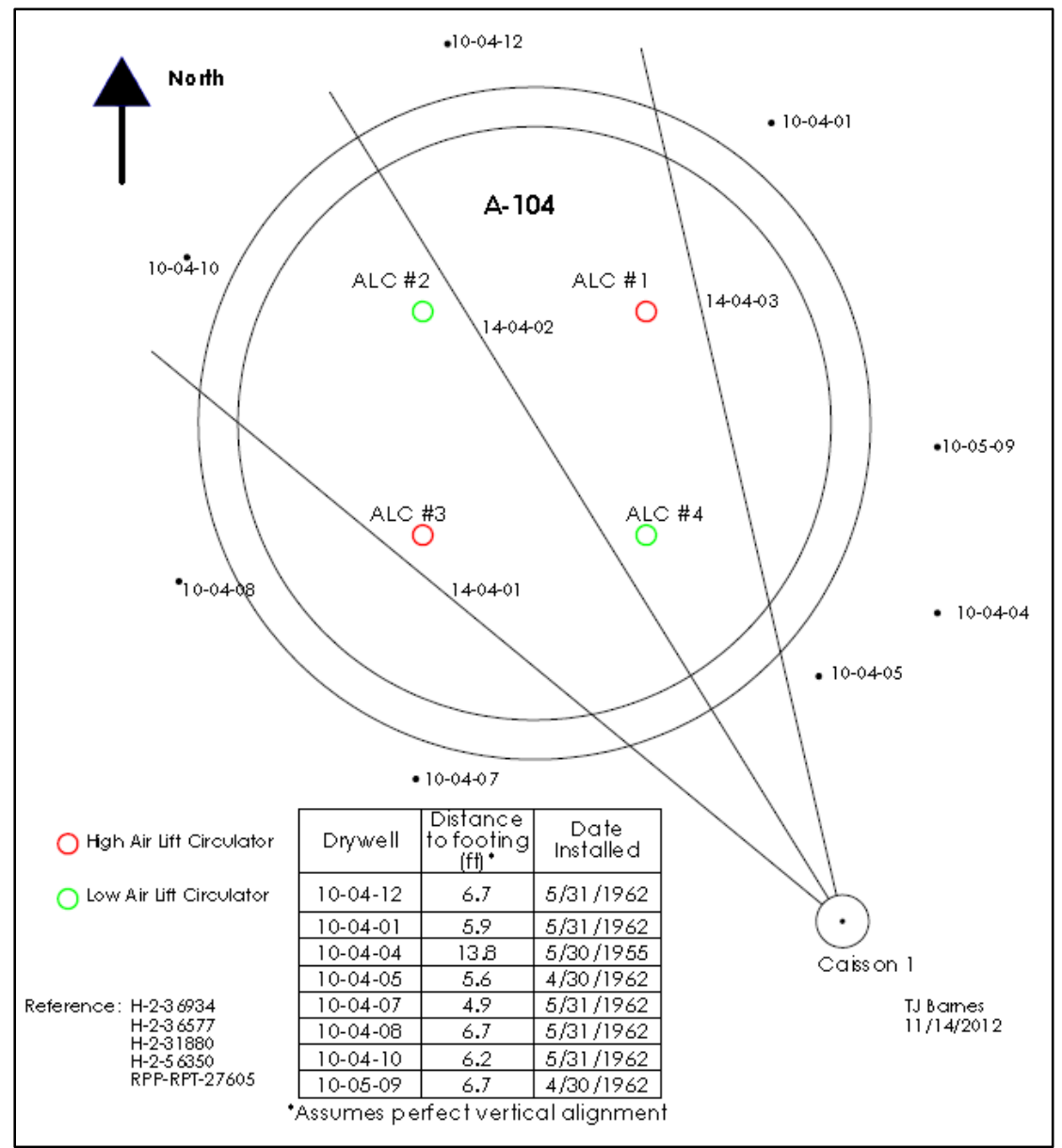


RPP-RPT-54912, Rev. 0

\subsection{TANK A-104 OPERATIONS SUMMARY}

Tank A-104 was constructed from February 1954 to January 1955 and sat unused until June 1957. In June 1957, $17 \mathrm{kgal}$ of "test water" were added to the tank (HW-51348, Chemical Processing Department Waste Status Summary for June 1, 1957 through June 30, 1957, page 8). The purpose of this test water and the source were not located in available records. It remains unclear if any water was added to the tank prior to June 1957 to counteract the vacuum pulled by the ventilation system. The monthly waste status summary reports recorded the volume of test water in tank A-104 which varied from $17 \mathrm{kgal}$ to $36 \mathrm{kgal}$ from June 1957 through July 1958. No explanation was located in the available records for the reported changes in the test water volume in tank A-104, but the variations could be due to calibrating instruments, additional test water added to the tank, and/or testing transfer systems.

In August 1958, tank A-104 received $20 \mathrm{kgal}$ of Plutonium Uranium Extraction (PUREX) high level waste (HLW) plus $100 \mathrm{kgal}$ of water (to slowly raise the temperature of the tank) (HW57328-DEL, Chemical Processing Department Monthly Report for August 1958, page J5-6). The tank was warming at $158^{\circ} \mathrm{F}$ for five months to January 1959 (HW-59079-DEL, Chemical Processing Department Monthly Report for January 1959, page J6). Transfers of PUREX HLW to tank A-104 started in January 1959 and self-concentration of waste was reported in August 1959 (HW-61952, Chemical Processing Department Waste Status Summary August 1, 1959 through August 31, 1959, page 8), which enabled additional PUREX HLW to be periodically transferred into the tank from January 1959 through December 1961. Organic wash waste (OWW) from PUREX was also reported to have been transferred to tank A-104 from 1960 through March 1968 (IDMS Accession \#D197260431, History - 241-A Tank Farm, and ARH534, Chemical Processing Division Waste Status Summary January 1, 1968 through March 31, 1968, page 9). The OWW was concentrated (i.e. evaporated) in the tank. The peak temperature reported for tank A-104 was $437^{\circ} \mathrm{F}$ on February 16, 1963, but was quickly reduced to below $340^{\circ} \mathrm{F}$ by March 1963 by adding OWW to the tank to increase the liquid level (RHO-CD-1172, Survey of the Single-Shell Tank Thermal Histories, page B-4). Prior to the maximum temperature recorded for tank A-104, from January 30, 1963 to February 15, 1963, OWW was being transferred into the tank (IDMS Accession \#D197260431). The PUREX Plant outage in December 1962 through January 1963 resulted in the lack of OWW for tank A-104 temperature control (HW-76443, Chemical Processing Department Monthly Report January 1963). Portable compressors were used to supply additional air to the air lift circulators which reduced the tank A-104 temperature (HW-76848, Chemical Processing Department Monthly Report February 1963). The waste volume in tank A-104 was generally maintained at less than $980 \mathrm{kgal}$ during self-concentration of wastes.

In the first and second quarters of 1969, a total of $669 \mathrm{kgal}$ of the OWW/PUREX HLW was transferred from tank A-104 to tank C-105 (ARH-1200 A, Chemical Processing Division Waste Status Summary January 1, 1969 through March 31, 1969, page 10, and ARH-1200 B, Chemical Processing Division Waste Status Summary April 1, 1969 through June 30, 1969, page 10), leaving approximately $171 \mathrm{kgal}$ of solids and $69 \mathrm{kgal}$ of supernatant in tank A-104. Sluicing of the solids from tank A-104 to tank A-106 was conducted from May 12, 1969 (ARH-1200 B, 
page 10) through October 1969 (ARH-1200 D, Chemical Processing Division Waste Status Summary October 1, 1969 through December 31, 1969, page 10). An estimated $3 \mathrm{kgal}$ of solids remained in tank A-104 following sluicing. The tank was refilled with $957 \mathrm{kgal}$ of tempered water from tank A-101 for a leak test to confirm integrity and the tank was declared a spare (ARH-1200 D, page 10). The water temperature in tank A-104 was reported as approximately $120^{\circ} \mathrm{F}$ following refilling the tank with water (RHO-CD-1172, page B-14). No additional temperature data for tank A-104 was found for the period of December 1969 through August 1974 (see PC Surveillance Analysis Computer System (PCSACS) for temperature data after 1974 to present).

No waste transfers were made into or out of tank A-104 until 1972. However, the liquid volume in tank A-104 decreased from $957 \mathrm{kgal}$ in October 1969 to approximately $259 \mathrm{kgal}$ in January 1972 (ARH-2456 A, Chemical Processing Division Waste Status Summary April 1, 1972 through June 30, 1972, page 9). A tube bundle heat exchanger (200,000 Btu/hr) was reported to be installed in tank A-104 (H-2-35091, Tk-104-A Heater, November 7, 1969) and removed in September 1974 (Occurrence Report 74-130, Contamination Spread), which may explain the liquid level decrease. However, the installation date of the heat exchanger remains unknown.

Approximately $132 \mathrm{kgal}$ of water was transferred from tank A-104 in the first and second quarters of calendar year 1972 (ARH-2456 A, page 9 and ARH-2456 B, Chemical Processing Division Waste Status Summary April 1, 1972 through June 30, 1972, page 9). Tank A-104 was then used to receive PUREX sludge supernatant (PSS waste type) from 244-AR Vault from the third quarter of calendar year 1972 (ARH-2456 C, Chemical Processing Division Waste Status Summary July 1, 1972 through September 30, 1972, page 9) through the second quarter of calendar year 1974 (ARH-CD-133 B, Operations Division Waste Status Summary April 1, 1974 through June 30, 1974, page 9). Tank A-104 also received 221-B Plant strontium solvent extraction waste (waste type B) in the fourth quarter of calendar year 1972 (ARH-2456 D, Chemical Processing Division Waste Status Summary October 1, 1972 through December 1, 1972, page 9) through first quarter of 1974 (ARH-CD-133 A, Operations Division Waste Status Summary January 1, 1974 through March 31, 1974, page 9), and water from tank A-103 in the first quarter of 1974. Excess supernatant from this mixture was periodically transferred to tanks in 241-AX Farm.

The PSS waste type contained PUREX sludge solids that did not rapidly settle in the relatively small tank 244-AR-004 in 244-AR Vault and were transferred to the much larger tank A-104 for settling (see Section 4.4.4). A total of approximately $80 \mathrm{kgal}$ of PUREX sludge solids and 726 kgal of PSS were present in tank A-104 in third quarter of calendar year 1974 (ARH-CD-133 B, page 9).

Prior to sluicing tank A-104, the supernatant was pumped out of the tank leaving the liquid level reported at 56-in (or $\sim 155 \mathrm{kgal}$ ) on September 1, 1974. Sluicing of the accumulated solids in tank A-104 to the 244-AR Vault was started in September 1974 and was halted April 7, 1975, due to an increase in the radiation detected in lateral 14-04-02 beneath the tank. The location of the peak activity detected in lateral 14-04-02 (center lateral) was “... approximately 18-ft in from 
the northwest edge of the tank," and “... On swing shift of April 8, 1975, a second radiation peak was observed in the same lateral and an adjacent lateral [lateral no. 1], located approximately 13 feet in from the southeast edge of the tank" (OR 75-39, Leakage from Tank 104-A). Gross gamma scans of drywells 10-04-01, 10-05-09, 10-04-04, 10-04-05, 10-04-07, 10-04-08, 10-0410, and 10-04-12 did not indicate radioactivity above background (see Sections 4.5.1 and 4.5.2.9). Tank A-104 contained $65 \mathrm{kgal}$ of waste, including an estimated $25 \mathrm{kgal}$ of sludge when the radioactivity was detected in the laterals. Tank A-104 was declared a confirmed leaker in April 1975 (Occurrence Report 75-39). It was reported that no definite relationship between the tank leak and sluicing operation was established (RHO-ST-30, Hanford Radioactive Tank Cleanout and Sludge Processing). Approximately $47 \mathrm{kgal}$ of supernatant were pumped from tank A-104 from April 9 through April 19, 1975 (Occurrence Report 75-39). Tank A-104 was declared interim stabilized in September 1978 and 1986 photographs indicate a dry, cracked waste surface with no visible liquid present (RHO-CD-213, Waste Storage Tank Status and Leak Detection Criteria 200 East Area- Volume 1).

The operational history of tank A-104 leak related details including temperature and liquid level is charted in Figure 4-2. 
Figure 4-2. Operational Leak History of Tank A-104

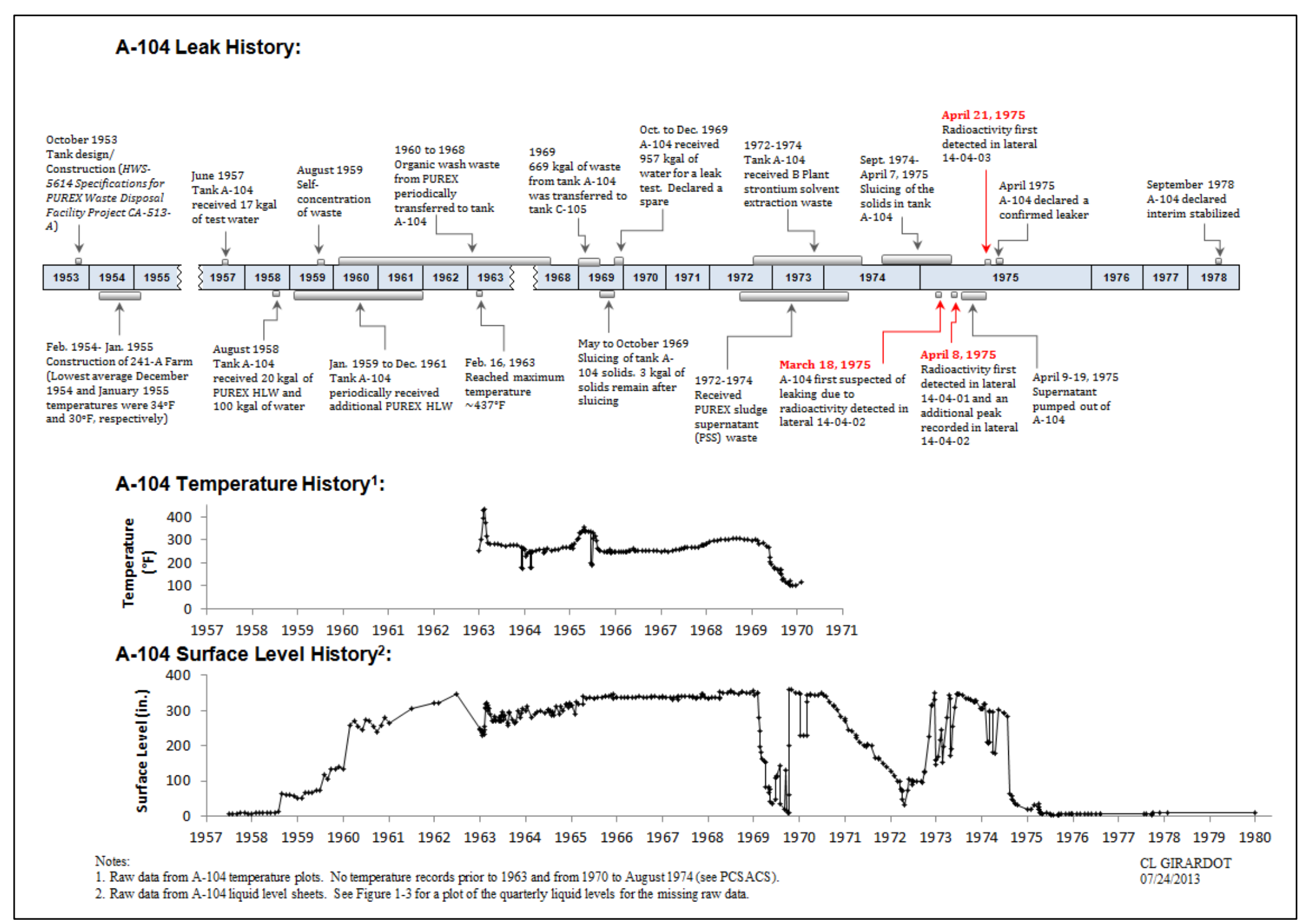


RPP-RPT-54912, Rev. 0

\subsection{TANK DESIGN/CONSTRUCTION}

\subsubsection{Tank Design}

The A Farm tanks had multiple design features that could contribute to stresses or possible leak paths when the tank was being operated including:

- Orthogonal intersection between the flat steel bottom and the sidewall

- Fillet weld used between the bottom and sidewall intersection

- Less rigorous weld inspection testing

- Partial asphaltic membrane waterproofing

These features are common to all A Farm tanks (see Section 3.1.1).

\subsubsection{Tank Construction Conditions}

A Farm was constructed from February 1954 to January 1955. Minimum temperatures of $32^{\circ} \mathrm{F}$ and below were experienced on 108 days during construction; however, no minimum temperatures below $0^{\circ} \mathrm{F}$ were experienced. The lowest average temperatures occurred in December 1954 at $34^{\circ} \mathrm{F}$ and January 1955 at $30^{\circ} \mathrm{F}$ with four months having at least one minimum temperature between $14^{\circ} \mathrm{F}$ and $18^{\circ} \mathrm{F}$ (PNNL-15160, Hanford Site Climatological Summary 2004 with Historical Data).

As described in Section 3.1.2, cold weather affects the ductile-to-brittle steel transition temperature, with $18^{\circ} \mathrm{F}$ being the assumed unrestricted low temperature construction limitation for the carbon steel liner, which could result in a fracture upon impact. Temperatures during the A Farm construction time frame were milder than those experienced during 241-SX Farm construction where ductile-to-brittle steel transition temperatures were exceeded.

Weather precautions for welding and concrete were specified in HW-4926-S, Standard Specification for Welding Carbon Steels (see Section 3.1.2).

\subsection{TANK A-104 IN-TANK DATA}

\subsubsection{Liquid Level}

The tank A-104 liquid level was apparently not reviewed for a decrease when radioactivity was first detected in lateral 14-04-02 in March 1975 as no mention was found in any of the monthly reports, individual letters, or previous leak assessment reports examined for this report. During this time, solids in tank A-104 were being sluiced which started September 1974 and was halted April 7, 1975 after radioactivity was detected in the laterals underneath the tank. The near constant transfers into and out of the tank during sluicing probably interfered with any meaningful liquid level analysis for a tank leak.

The liquid level plot in Figure 4-3 indicates the transfers into and out of the tank. The liquid levels are end of quarter levels so this figure may not reflect all significant transfers into and out 
of tank A-104 that occurred during the operational history of the tank. See Figure 4-2 for historical monthly liquid level readings.

Figure 4-3. Tank A-104 End of Quarter Surface Level

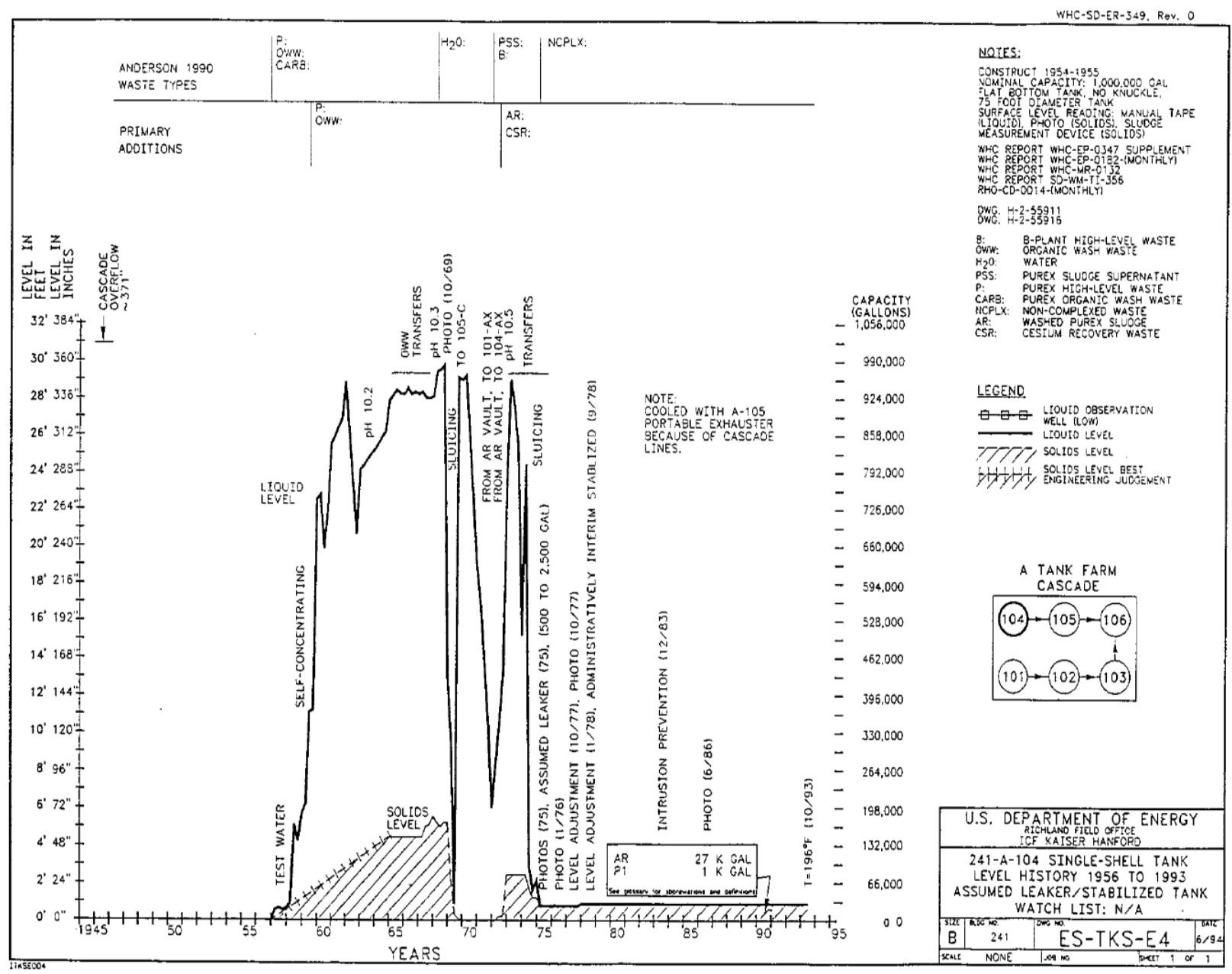

WHC-SD-WM-ER-349, Rev 0, June 1994, Historical Tank Content Estimate for the Northeast Quadrant of the Hanford 200 East Area

\subsubsection{Temperature}

Document HW-59919, Limitations for Existing Storage Tanks for Radioactive Wastes from Separations Plants, issued October 22, 1959 states that tank contents should be heated slowly to not exceed the recommended rate of $2^{\circ} \mathrm{F}$ per day along with other temperature requirements for filling boiling waste tanks. The temperature requirements for filling boiling waste tanks are designed to provide enough time at controlled temperature and other waste parameters (specific gravity and liquid depth) to remove grout moisture gradually so that the grout moisture vapor pressure does not exceed the hydrostatic pressure. Bulging of the tank bottom liner can be caused by grout vapor pressure exceeding the hydrostatic pressure. The recommended uniform rate of temperature increase was also designed to prevent exceeding the maximum temperature gradient across the structural components of the tanks. 
Tank A-104 was initially filled with $17 \mathrm{kgal}$ of test water in June 1957 and sat unused until August 1958. Temperatures during this time could not be recovered. Beginning in August 1958, tank A-104 was initially filled with $20 \mathrm{kgal}$ of PUREX HLW and $100 \mathrm{kgal}$ of water and the temperature held at $158^{\circ} \mathrm{F}$ for five months to January 1959. Tank A-104 periodically received PUREX HLW from January 1959 through December 1961 and OWW from PUREX from 1960 to 1968. Self-concentration of waste started in August 1959 (RHO-R-39, Boiling Waste Tank Farm Operational History). However, no other temperature data for tank A-104 could be recovered from June 1957 to January 1963. Temperatures were recorded as approximately $257^{\circ} \mathrm{F}$ on January 2,1963 and gradually rose to $428^{\circ} \mathrm{F}$ by February 6,1963 ; the temperature rate of rise was therefore approximately $4.9^{\circ} \mathrm{F} /$ day. On February 16, 1963, a maximum waste temperature of approximately $437^{\circ} \mathrm{F}$ was reached (see Figure 4-2).

Temperatures gradually declined to approximately $260^{\circ} \mathrm{F}$ by December 1963 and remained relatively stable at this temperature through January 1965. In February 1965, waste temperatures began to increase and reached above $300^{\circ} \mathrm{F}$ by March 1965 and peaked at $\sim 356^{\circ} \mathrm{F}$ at the end of April 1965 and remained above $300^{\circ} \mathrm{F}$ through July 1965. In August 1965, temperatures gradually declined to approximately $250^{\circ} \mathrm{F}$ and remained relatively stable through May 1967 . Beginning in June 1967, temperatures slowly increased and reached slightly over $300^{\circ} \mathrm{F}$ by May 1968 and remained around $300^{\circ} \mathrm{F}$ until February 1969. Temperatures then gradually declined with sluicing of the solids in tank A-104 from May to October 1969. No temperature data was recovered from March 1970 until August 1974.

Tank A-104 was first suspected of leaking in March 1975 when radioactivity was detected in lateral 14-04-02 during sluicing of the tank solids which was started September 1974. Temperature data could not be located during this time. In PCSACS, a single temperature was recorded August 25, 1974 at $177^{\circ} \mathrm{F}$. No additional data is available until April 1976 when temperatures were approximately $170^{\circ} \mathrm{F}$ (PCSACS); therefore, it is likely temperatures in March 1975 were roughly the same.

Document HW-59919 indicated that the self-boiling waste operating temperature should be maintained between $220^{\circ} \mathrm{F}$ and $250^{\circ} \mathrm{F}$ (see Section 3.2.2). The maximum sludge temperature should not exceed $300^{\circ} \mathrm{F}$. As noted, the temperature exceeded this level multiple times during operation and approximately 17 months had temperatures recorded greater than $300^{\circ} \mathrm{F}$.

\subsubsection{Liner Observations}

A bulge in a tank liner may result in the direct failure of the liner or cause enough stress or thinning on the steel liner plates and welds that they become more susceptible to the effects of corrosion. Experience indicates that bulging tends to be a dynamic phenomenon, and it is possible that a tank with no measured bulge at one point in time may actually have had a displaced liner that was not detected at another time. A thinning or weakened location may be more susceptible to corrosion (see Section 3.2.3).

Document RHO-R-39, issued December 18, 1969, lists tank A-104 as having been inspected for a liner bulge (see Appendix A1). However, a liner bulge was not identified. No additional documentation was found indicating a bottom liner bulge in tank A-104. A review of tank A- 
104 photographs indicates there is a possibility a bulge was present at one time due to the presence of failed ALC turnbuckle guy rod attachments (see Section 4.4.5).

No other liner observations relating to a tank A-104 leak have been found.

\subsubsection{Chemistry-Corrosion}

Test water was added to tank A-104 in June 1957 and remained in the tank for one year. However, the purpose of this test water remains unknown and no mention of the water source or chemical adjustment has been found in any of the documents reviewed. Waste temperatures were not recovered until 1963. Tank A-104 first received waste in August 1958 and stored various waste types throughout operation as shown in Table 4-1. The typical concentrations for nitrite, nitrate, and hydroxide for these waste types are shown in Table 4-2. Nitrite and hydroxide are known as nitrate-induced SCC inhibitors. One key characteristic for inhibiting SCC is to maintain a high nitrite concentration to nitrate concentration ratio (see Section 3.2.4).

Table 4-1. Tank A-104 Waste Storage Chronology

\begin{tabular}{|c|c|c|}
\hline Date & Waste Type & Length of Storage \\
\hline June 1957 to July 1958 & Water & $\sim 1$ year \\
\hline August 1958 to December 1961 & PUREX HLW & $\sim 31 / 2$ years \\
\hline 1960 to March 1968 & OWW & $\sim 8$ years \\
\hline October 1969 to August 1972 & Water & $\sim 3$ years \\
\hline 1972 to 1974 & PSS/B & $\sim 2$ years \\
\hline
\end{tabular}

Table 4-2. Waste Chemistries for Waste Types Stored in Tank A-104

\begin{tabular}{|l|c|c|c|c|}
\hline \multicolumn{1}{|c|}{ Waste Types } & {$\left[\mathbf{N O}_{3}{ }^{-}\right]$} & {$\left[\mathbf{N O}_{2}{ }^{-}\right]$} & {$\left[\mathbf{O H}^{-}\right]$} & $\begin{array}{c}\text { Meets Current } \\
\text { DST Specification }\end{array}$ \\
\hline $\mathrm{B}^{1}$ & 1.27 & Not Reported & Not Reported & Not available \\
\hline PSS $^{1}$ & 4.2 & 0.22 & $0.48^{4}$ & No $^{6}$ \\
\hline OWW $^{1}$ & 0.06 & Not Reported & Not Reported & Yes $^{7}$ \\
\hline PUREX HLW $^{1}$ & 1.3 & $3.37^{5}$ & Not Reported & Yes \\
\hline Water $^{2}$ & $1.3 \times 10^{-7}$ & $4.2 \times 10^{-6}$ & $6.3 \times 10^{-7}$ & Yes \\
\hline
\end{tabular}

1. Reference WHC-EP-0449, 1991, The Sort on Radioactive Waste Type Model: A Method to Sort Single-Shell Tanks into Characteristic Groups.

2. Assumed to be raw water. Reference ERDA-1538, Final Environmental Statement, Vol. 2, December 1975, average chemical concentrations from October 1971 to September 1972.

3. Reference OSD-T-151-00007, Rev. 12, (2013), Operating Specifications for the Double-Shell Storage Tanks.

4. Reference IDMS Accession \#D196248072, Analysis of Tank Farm Samples Sample: T-2893 Tank 104-A.

5. Average of three A Farm PUREX waste samples, RL-SEP-183 RD, PUREX Tank Farm Supernatant Solution Composition.

6. Does not meet the current DST specification since the hydroxide and nitrite concentrations are not greater than or equal to $1.2 \mathrm{M}$.

7. According to the assumption from reference WHC-EP-0772, Characterization of the Corrosion Behavior of the Carbon Steel Liner in Hanford Site Single-Shell Tanks.

In February 1969, prior to pumping the tank A-104 supernatant out to prepare for sluicing, the waste was reported to be at a $\mathrm{pH}$ of 10.35 with concentrations of nitrate and nitrite to be $0.32 \mathrm{M}$ 
RPP-RPT-54912, Rev. 0

and 3.36 M, respectively (IDMS Accession D196248068, Tk-104-A Analyses). These results indicate the waste during this period does not exceed the chemistry limits for preventing SCC.

Tank A-104 stored tempered water from tank A-101 from October 1969 to August 1972. No sample information was found for this period. However, it is assumed that the tempered water added to the tank during this time was raw water at a $\mathrm{pH}$ of approximately 7.8 (ERDA-1538) as this was common tank farm practices. Temperatures during October to December 1969 ranged from approximately 104 to $120^{\circ} \mathrm{F}$ (see Figure 4-2). Some corrosion may have occurred during the storage of water initially in 1957 and later in 1969 (for approximately 4 years total); however, it remains inconclusive.

Tank A-104 was sampled March 25, 1974, shortly before the supernatant was pumped out to allow sluicing to start in September 1974. Results report the $\mathrm{pH}$ of the sample to be 10.49 and hydroxide concentration of 0.48 M (SD-WM-TI-302, Hanford Waste Tank Sluicing History and IDMS Accession \#D196248072, Analysis of Tank Farm Samples Sample: T-2893 Tank 104-A).

Under flowsheet conditions PUREX HLW would not be considered to have a high propensity for corrosion of the tank steel liner. Waste type PSS could create an environment conducive to SCC; however, frequent transfers into and out of the tank were occurring during this time and PSS would likely be diluted with B waste type. Tank A-104 stored waste type B and PSS from 1972 to 1974, storing for approximately three years before the tank was first suspected of leaking in March 1975.

\subsubsection{Photographs}

Earliest available photographs of tank A-104 taken on October 7, 1969 were reviewed. However, it is difficult to determine if a bulge was present at this time due to poor lighting and the waste surface is liquid. There are two ALCs (ALC \#1 and ALC \#2) that have bent piping and turnbuckle guy rods hanging free and are shown in Figure 4-4 and Figure 4-5. The next available sets of photographs were taken April 29, 1975 and May 14, 1975, shortly after tank A104 was declared a confirmed leaker. However, it is difficult to determine if a bulge is present from these photographs due to the cloudiness of the photographs.

All available photographs of tank A-104 were reviewed. Photographs of tank A-104 taken June 25, 1986 show ALC \#3 (see Figure 4-6) and ALC \#4 (see Figure 4-7) with turnbuckle guy rods hanging free. This may be an indication of a liner bulge that could have resulted in failure of the turnbuckle guy rod bottom liner attachment. However, it remains unclear from the available photographs if the bottom liner of tank A-104 bulged. 


$$
\text { RPP-RPT-54912, Rev. } 0
$$

Figure 4-4. Tank A-104 ALC \#1 Photograph 0694459-34

October 7, 1969

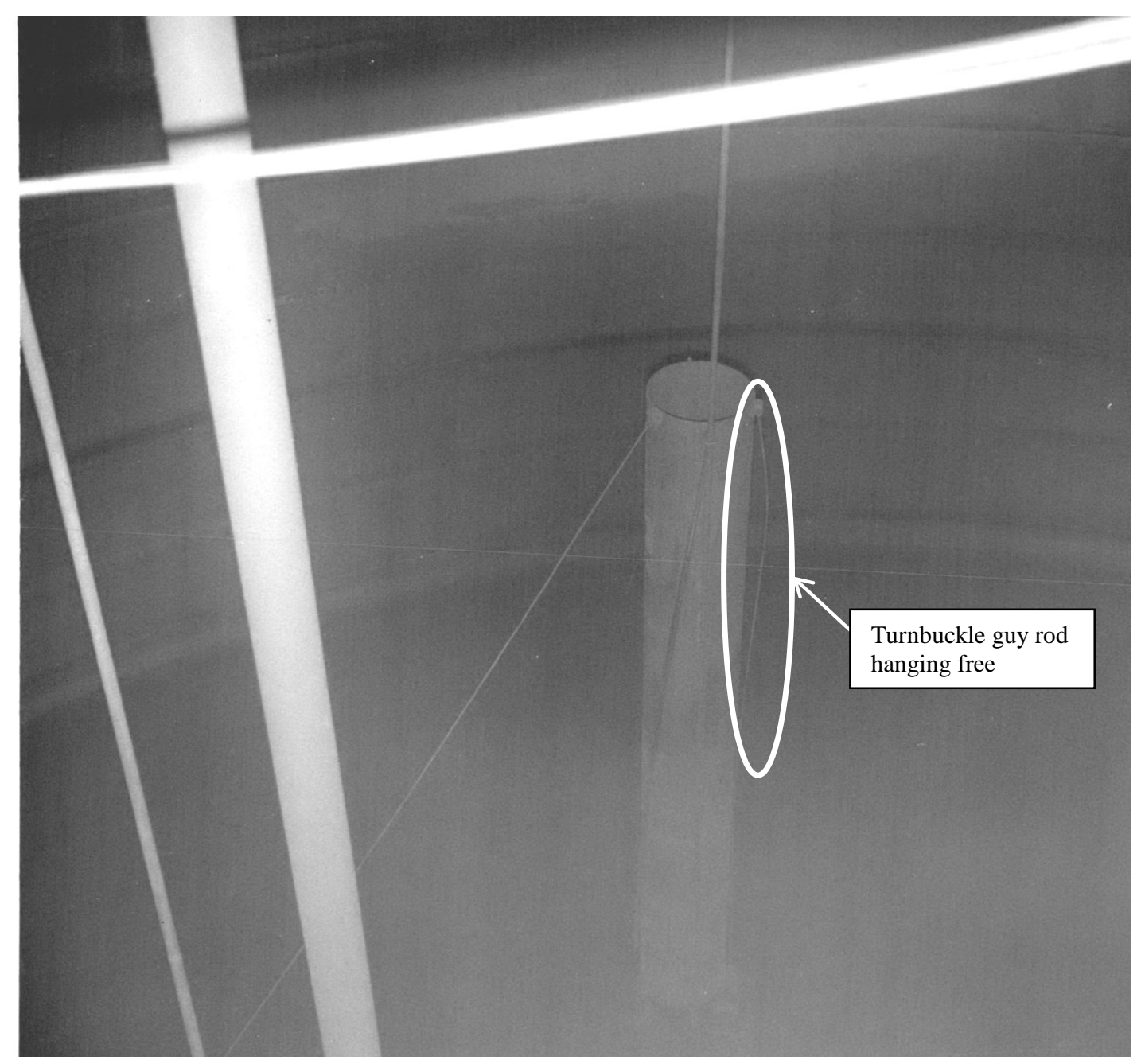




$$
\text { RPP-RPT-54912, Rev. } 0
$$

Figure 4-5. Tank A-104 ALC \#2 Photograph 0694459-20

October 7, 1969

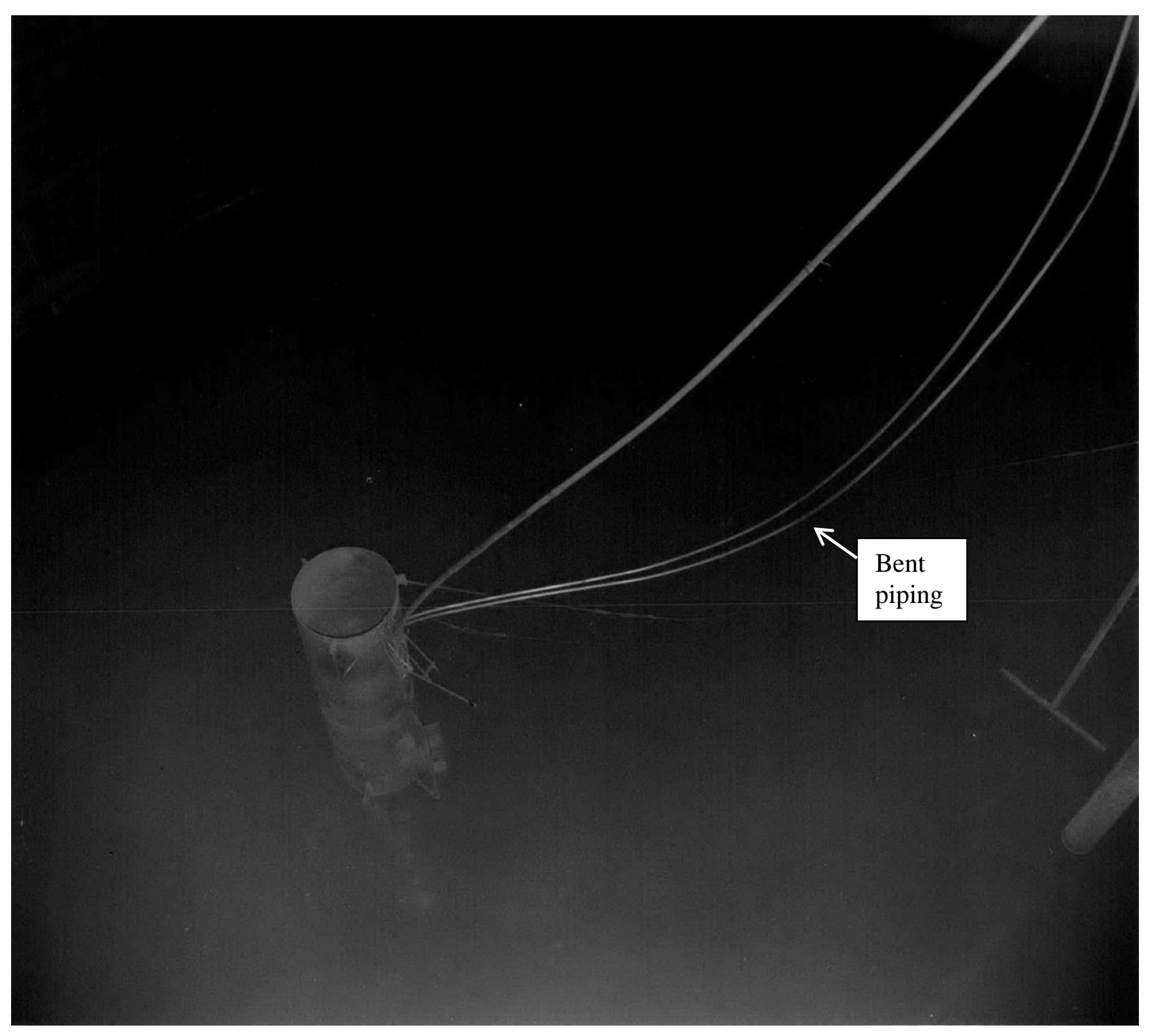




$$
\text { RPP-RPT-54912, Rev. } 0
$$

Figure 4-6. Tank A-104 ALC \#3 Photograph 8604129-22CN June 25, 1986

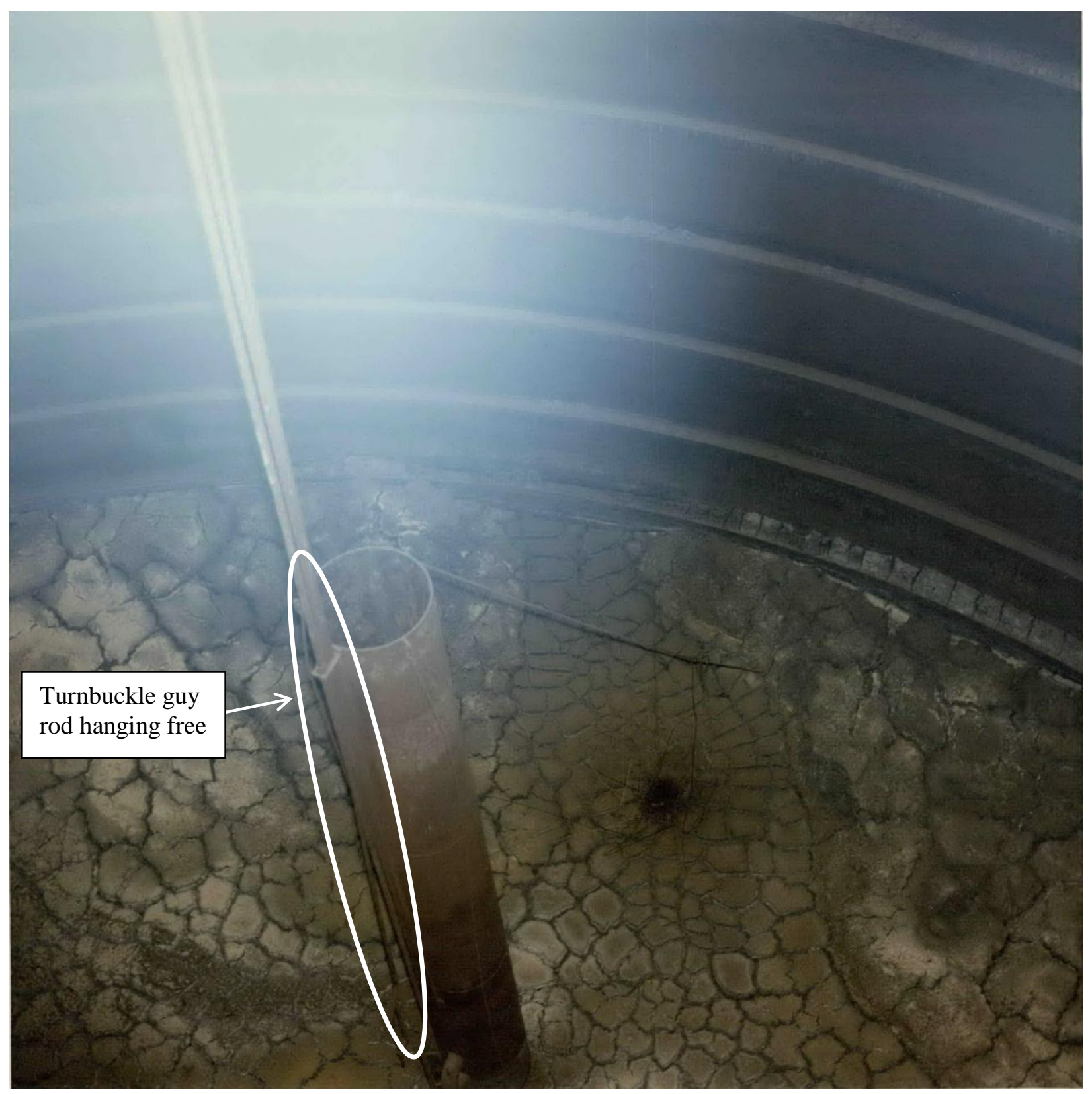


RPP-RPT-54912, Rev. 0

Figure 4-7. Tank A-104 ALC \#4 Photograph 8604129-24CN June 25, 1986

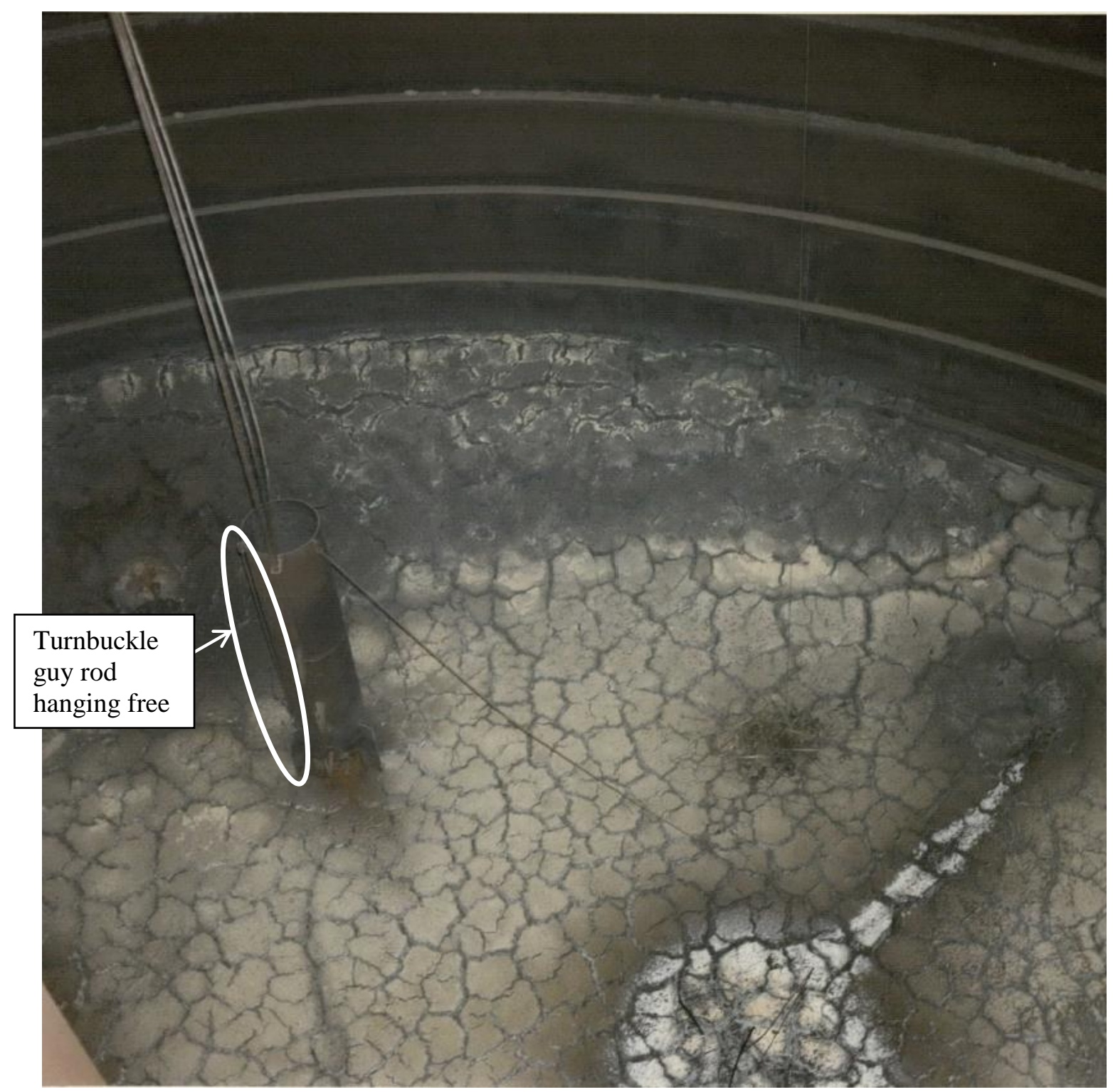

\subsection{TANK A-104 EX-TANK DATA}

\subsubsection{Laterals}

The first indication of a tank A-104 leak occurred in March 1975, shortly after the start of sluicing in September 1974, when radioactivity was detected in lateral 14-04-02 (see Table C11). On March 18, 1975, the first indication of a tank A-104 leak was reported at 100 counts per minute (cpm) in lateral 14-04-02 at approximately 94-ft from the caisson. A week later, counts increased to $305 \mathrm{cpm}$ at that location in lateral 14-04-02. Sluicing was halted April 7, 1975 due to the increase in radioactivity in lateral 14-04-02. During this time, tank A-104 contained 65 kgal of waste, including an estimated $25 \mathrm{kgal}$ of sludge. The following day on April 8, 1975, 
additional radiation peaks were recorded, one in lateral 14-04-02 and one in lateral 14-04-01, both along the southeast edge of the tank (see Figure 4-8). Radiation readings were monitored daily in April 1975 for all three laterals and data are shown in Appendix C1. Radiation readings continued to increase in laterals 14-04-01 and 14-04-02 throughout April 1975. The first indication of radioactivity in lateral 14-04-03 occurred on April 21, 1975 at a reading of $95 \mathrm{cpm}$ along the northeast edge of the tank and increased to $480 \mathrm{cpm}$ by May 2, 1975. Tank A-104 was declared a confirmed leaker in April 1975 and supernatant was pumped out of tank A-104 from April 9 through April 19, 1975.

Beginning on May 1, 1975 a new peak was recorded in lateral 14-04-02 at 47-ft from the caisson at 1,200 cpm. A new peak was also recorded in lateral 14-04-01 on May 19, 1975 at 45-ft from the caisson. Gross gamma scans of the drywells around tank A-104 did not indicate radioactivity above background during this time (ARH-LD-120, Nuclear Waste Tank and Pipeline External Leak Detection Systems). Radiation readings remained relatively stable through 1976 and lateral scans from 1977 are shown in Figure 4-9, which show similar peaks when compared to the 1975 data. See Appendix C1 for lateral data from July 1974 through June 1986.

Figure 4-8. Tank A-104 Historical Lateral Radioactivity December 1975 (ARH-LD-120)

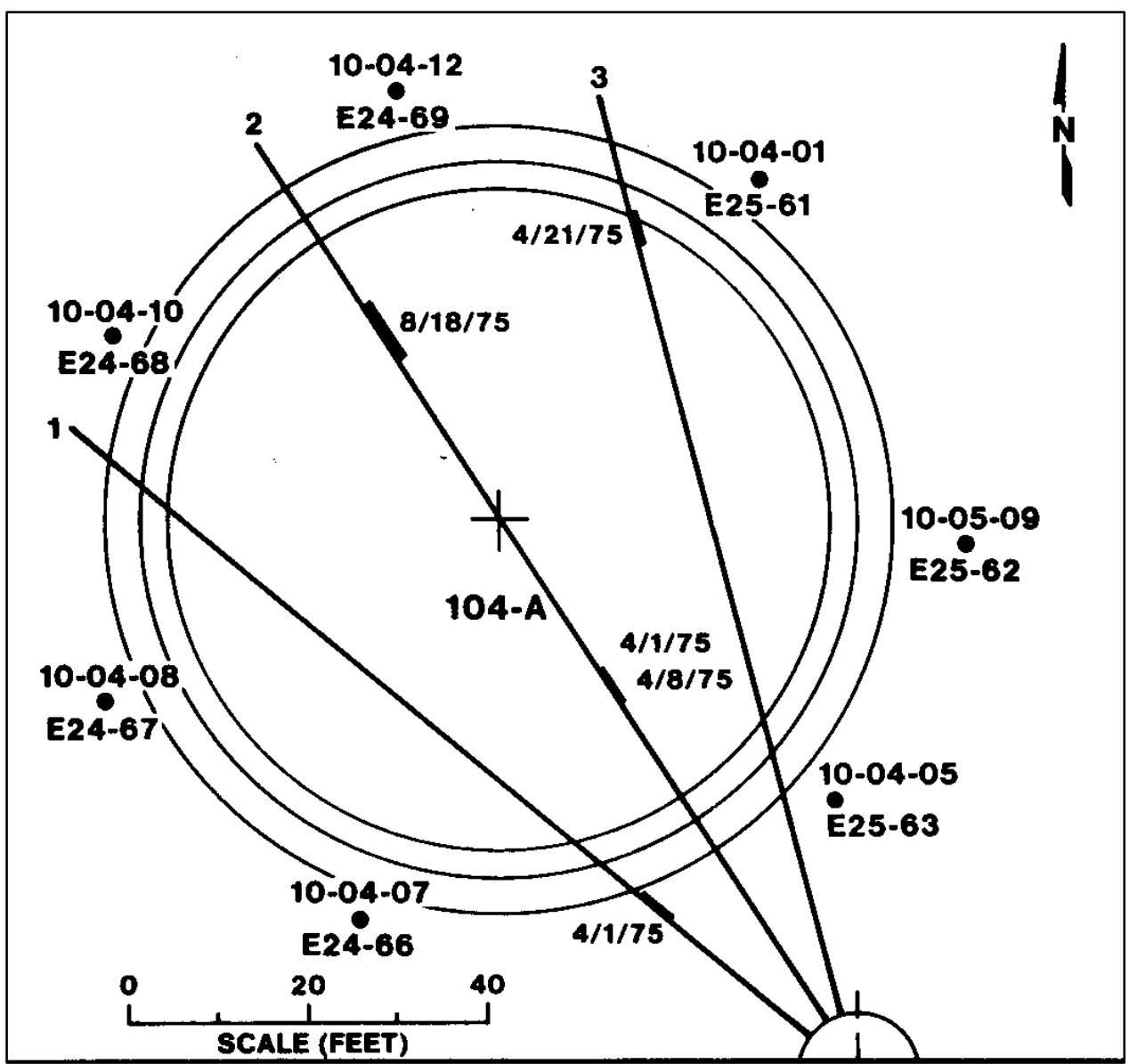

Note: There appears to be conflicts with the dates reported on this figure compared to the lateral data recovered in Appendix C1 
RPP-RPT-54912, Rev. 0

Figure 4-9. Tank A-104 Historical Lateral Surveys (counts per second) (RPP-RPT-27605, Rev. 0)

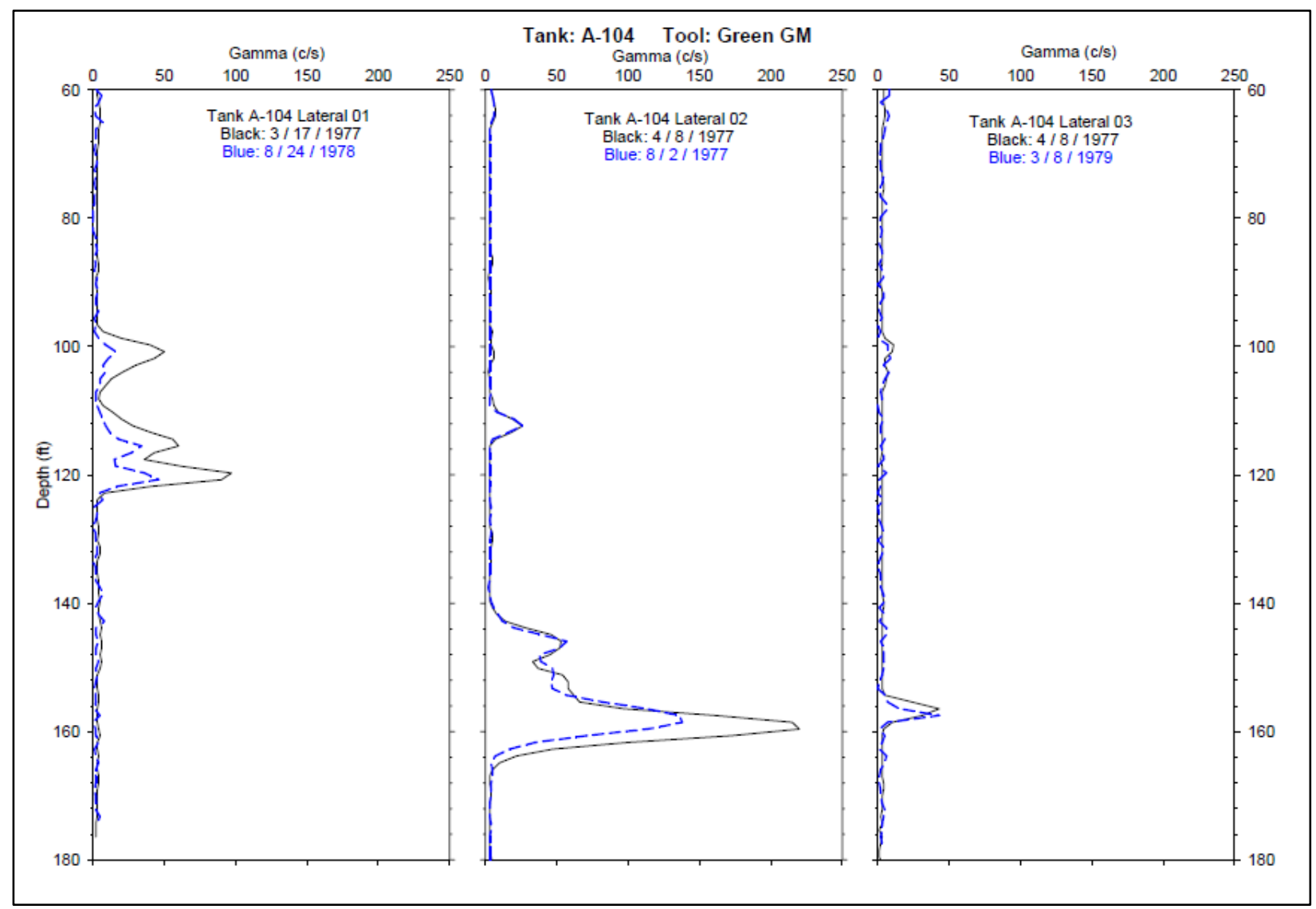

The historical gross gamma profiles shown in Figure 4-9 for laterals 14-04-01, 14-04-02, and 1404-03 (RPP-35484, Field Investigation Report for Waste Management Areas C and A-AX, page 3-91) indicate that the contaminant or contaminants emitting this radiation were relatively shortlived (e.g., ruthenium-106, cerium-144). The April 2005 gamma surveys (see Figure 4-10 and Figure 4-11) under tank A-104 did not identify any gamma activity above background levels (RPP-RPT-27605). Lateral 14-04-03 was not surveyed during this time. 
RPP-RPT-54912, Rev. 0

Figure 4-10. Summary Gamma Survey for Lateral 14-04-01 on Logarithmic Scale April 20, 2005

(RPP-RPT-27605, Rev. 0)

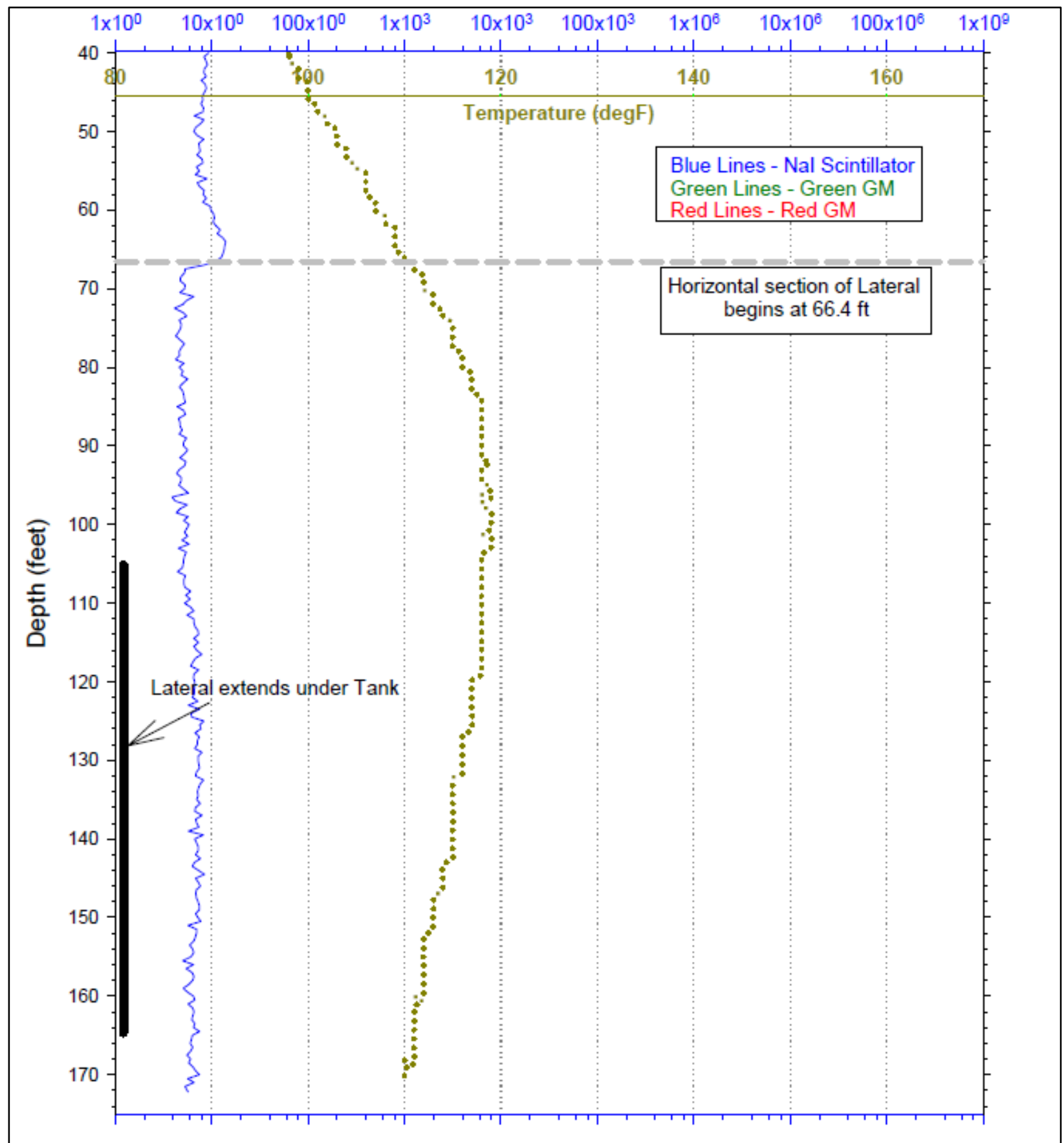

Note: The lateral was not scanned with the Green and Red GM probes due to sensitivity and the level of radioactivity measured with the NaI Scintillator probe. 
RPP-RPT-54912, Rev. 0

Figure 4-11. Summary Gamma Survey for Lateral 14-04-02 on Logarithmic Scale

April 21, 2005

(RPP-RPT-27605, Rev. 0)

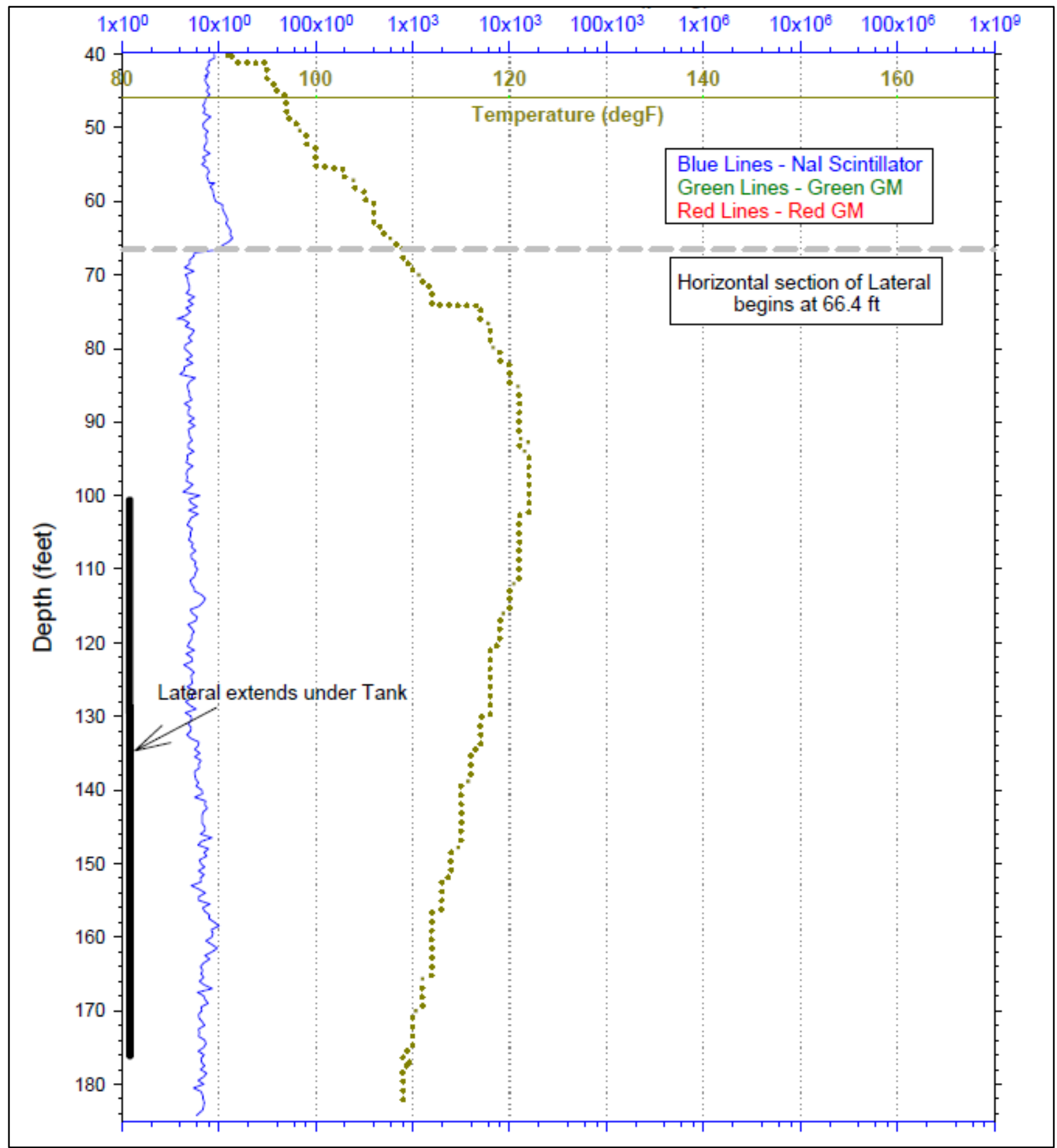

Note: The lateral was not scanned with the Green and Red GM probes due to sensitivity and the level of radioactivity measured with the NaI Scintillator probe. 


\subsubsection{Drywells}

There are eight drywells located around tank A-104: 10-04-04 installed in May 1955 and 10-0401, 10-05-09, 10-04-05, 10-04-07, 10-04-08, 10-04-10, and 10-04-12 installed in April/May 1962. All of the radiation readings in drywells are assumed to be maximum or peak readings unless otherwise noted (see Section 3.3.2). The following subsections report the available drywell information and the drywell summary section provides the analyses of the associated drywells with tank A-104.

\subsubsection{Drywell 10-04-01}

Drywell 10-04-01 was drilled in May 1962 with the first recoverable reading on January 7, 1965 with three peaks of $7 \mathrm{cpm}, 6 \mathrm{cpm}$, and $15 \mathrm{cpm}$ at $50-\mathrm{ft}, 70-\mathrm{ft}$, and $75-\mathrm{ft} \mathrm{BGS}$, respectively (see Appendix D1). These low-level radioactivity peaks remained relatively stable through November 1965. The next recoverable reading was on September 13, 1972 and reported as less than values at this time through June 1986 probably due to short-lived radioisotopes.

In August 1998, Cs-137 was the only man-made radionuclide detected in drywell 10-04-01 with the maximum concentration of $8 \mathrm{pCi} / \mathrm{g}$ detected at $1-\mathrm{ft}$ BGS (GJ-HAN-109). At 51-ft BGS, Cs137 concentration was reported just above the minimum detectable limit at $\sim 0.2 \mathrm{pCi} / \mathrm{g}$. Document GJ-HAN-109 reports, "The near-surface anomalous activity was evident on the earliest available log (January 1975), which implies that the radionuclide contamination was in place before that time. There is no indication of anomalous activity in the borehole below the operating level of the tank." Therefore, drywell 10-04-01 is not included as part of the leak location for tank A-104. Figure 4-12 shows the depths of radioactivity from 1975 to 1995 (RPP8820, Analysis and Summary Report of Historical Dry Well Gamma Logs for the 241-A Tank Farm- 200 East). 
RPP-RPT-54912, Rev. 0

Figure 4-12. Tank A-104 Drywell 10-04-01 (RPP-8820)

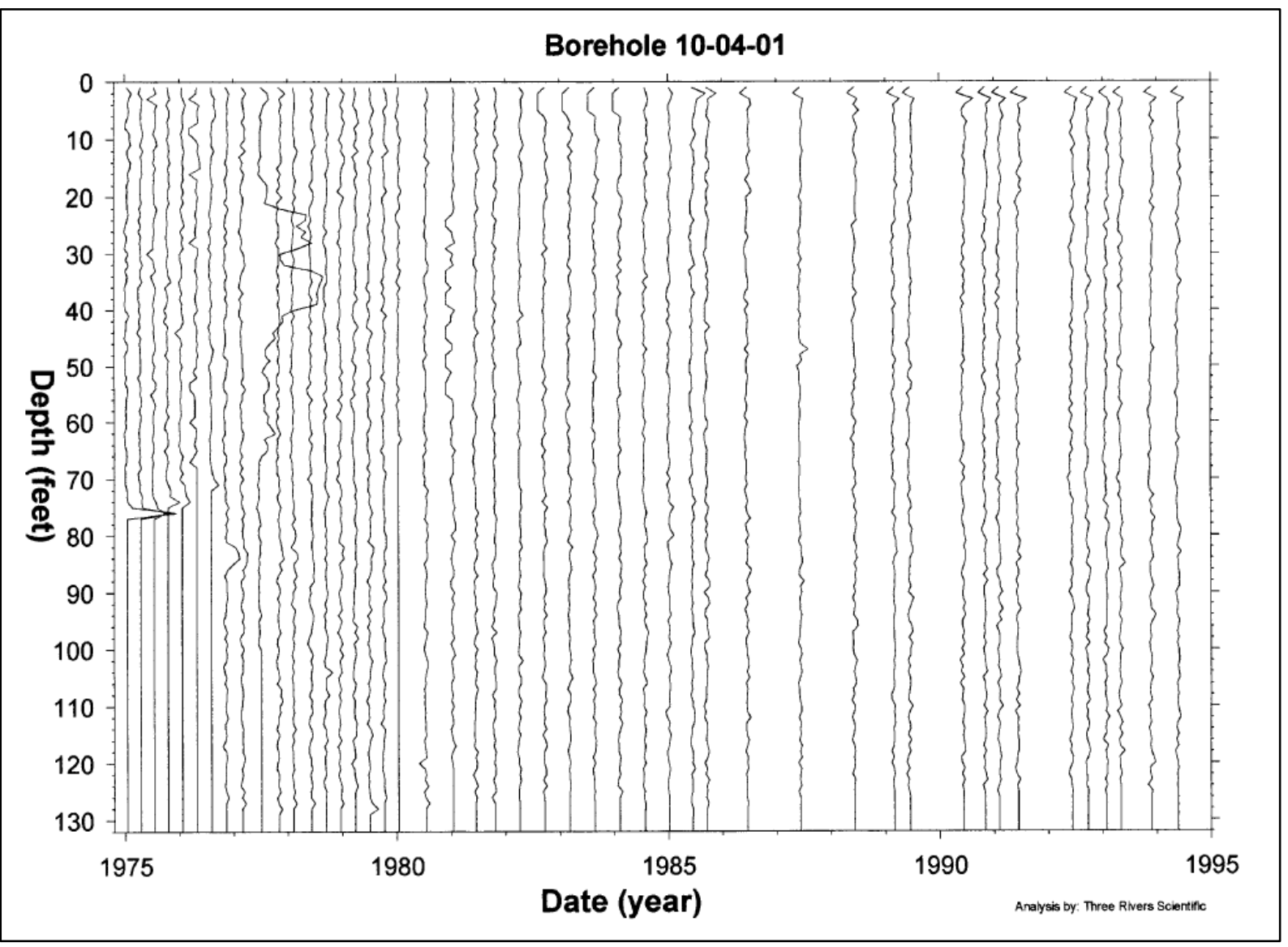

Note: Bottom of the tank footing is 47 -ft 10-in BGS

\subsubsection{Drywell 10-05-09}

Drywell 10-05-09 was drilled in April 1962 with the first recoverable reading on January 7, 1965 with a peak reading of $15 \mathrm{~K} \mathrm{cpm}$ at 15 -ft BGS (see Appendix D1). Radioactivity at this BGS level appeared to have been short-lived as radioactivity was relatively stable through January 1966. However, the two readings taken in May and August 1966 did not report radioactivity at the higher BGS level. The next recoverable reading was on September 13, 1972 and reported as less than values at this time through November 1986.

In August 1998, Cs-137 was the only man-made radionuclide detected in drywell 10-05-09 (GJHAN-110). From the ground surface to $15-\mathrm{ft}$ BGS, Cs-137 contamination was detected nearly continuously at concentrations ranging from $0.3 \mathrm{pCi} / \mathrm{g}$ to about $90 \mathrm{pCi} / \mathrm{g}$ at a depth of $1-\mathrm{ft}$ BGS. From 27.5 to $47-\mathrm{ft}$ BGS, Cs-137 was also detected intermittently at concentrations just above the minimum detection limit and from 51 to 76.5 -ft BGS at concentrations less than $1 \mathrm{pCi} / \mathrm{g}$. Document GJ-HAN-110 reports, "The Cs-137 contamination detected from the ground surface to a depth of $10 \mathrm{ft}$ probably resulted from a surface spill that migrated into the backfill sediment around the borehole. The contamination from 10 to $50 \mathrm{ft}$ was probably carried downward from the ground surface during the drilling operation. The Cs-137 concentrations below $50 \mathrm{ft}$ were too low to support shape factor analysis. Attempts to link this contamination to a source are 
speculative, but the contamination may be correlatable with contamination at this depth interval in borehole 10-05-10."

Therefore, drywell 10-05-09 is not included as part of the leak location for tank A-104. Figure 4-13 shows the depths of radioactivity from 1975 to 1995 (RPP-8820).

Figure 4-13. Tank A-104 Drywell 10-05-09 (RPP-8820)

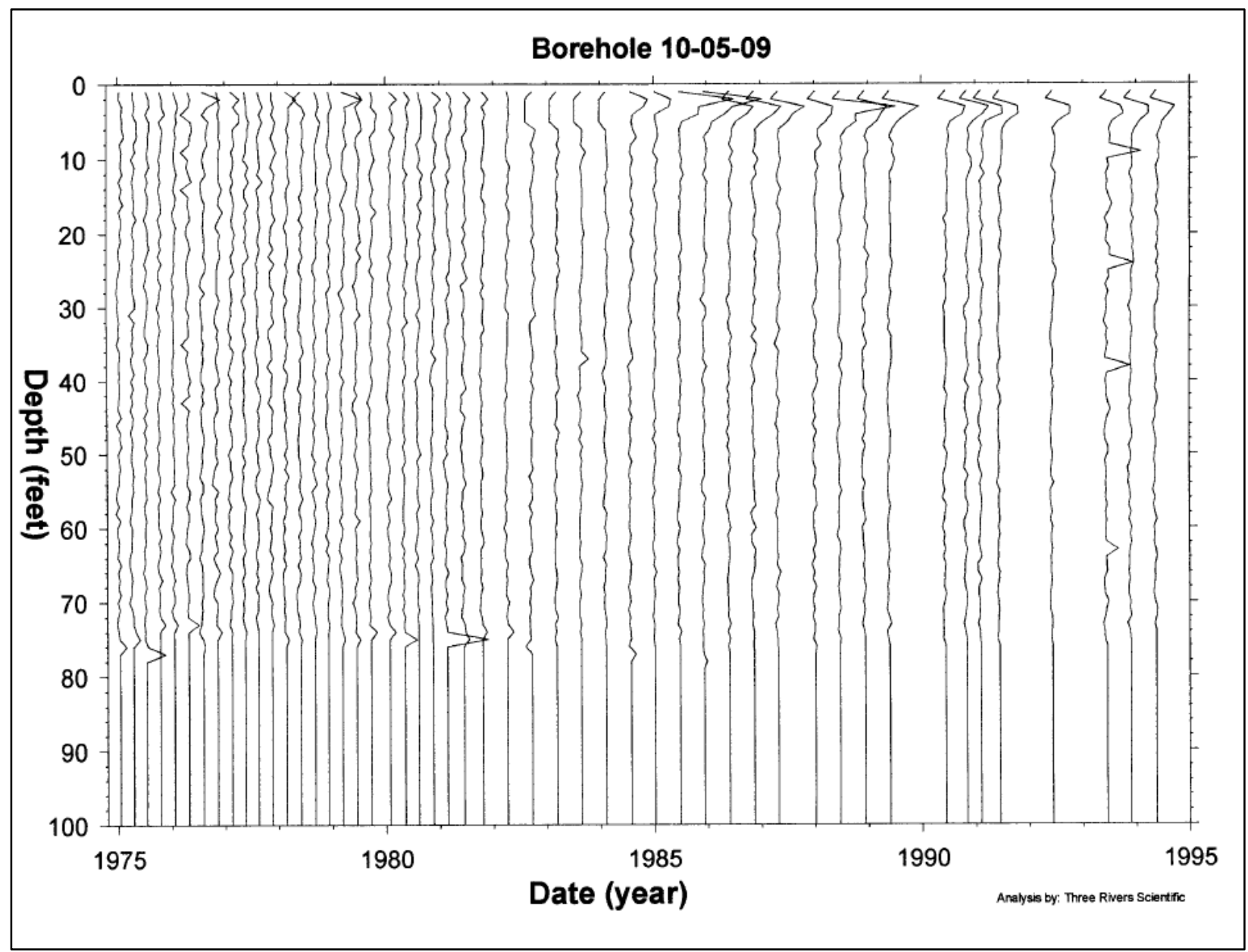

Note: Bottom of the tank footing is $\sim 47$-ft 10 -in BGS 


\subsubsection{Drywell 10-04-04}

Drywell 10-04-04 was drilled in May 1955 with the first recoverable readings on September 13, 1972 and reported as less than values at this time through November 1986 (see Appendix D1).

In August 1998, Cs-137 and Eu-154 were the only man-made radionuclides detected in drywell 10-04-04 (GJ-HAN-109). From the ground surface to 6.5-ft BGS, Cs-137 was detected continuously at concentrations ranging from 0.5 to $20 \mathrm{pCi} / \mathrm{g}$ and was detected at the bottom of the drywell at approximately $0.6 \mathrm{pCi} / \mathrm{g}$. From 4.5 to $6.5-\mathrm{ft} \mathrm{BGS}, \mathrm{Eu}-154$ was detected continuously at concentrations ranging from 0.5 to $0.8 \mathrm{pCi} / \mathrm{g}$. Document GJ-HAN-109 reports "Shape factor results support the interpretation that the man-made contaminants detected from the ground surface to $6.5 \mathrm{ft}$ resulted from a surface spill, a nearby pipeline, or a combination of these. The contamination at the bottom of the borehole is most likely particulate matter that has fallen into the borehole from the ground surface." Therefore, drywell 10-04-04 is not included as part of the leak location for tank A-104. Figure 4-14 shows the depths of radioactivity from 1975 to 1995 (RPP-8820).

Figure 4-14. Tank A-104 Drywell 10-04-04 (RPP-8820)

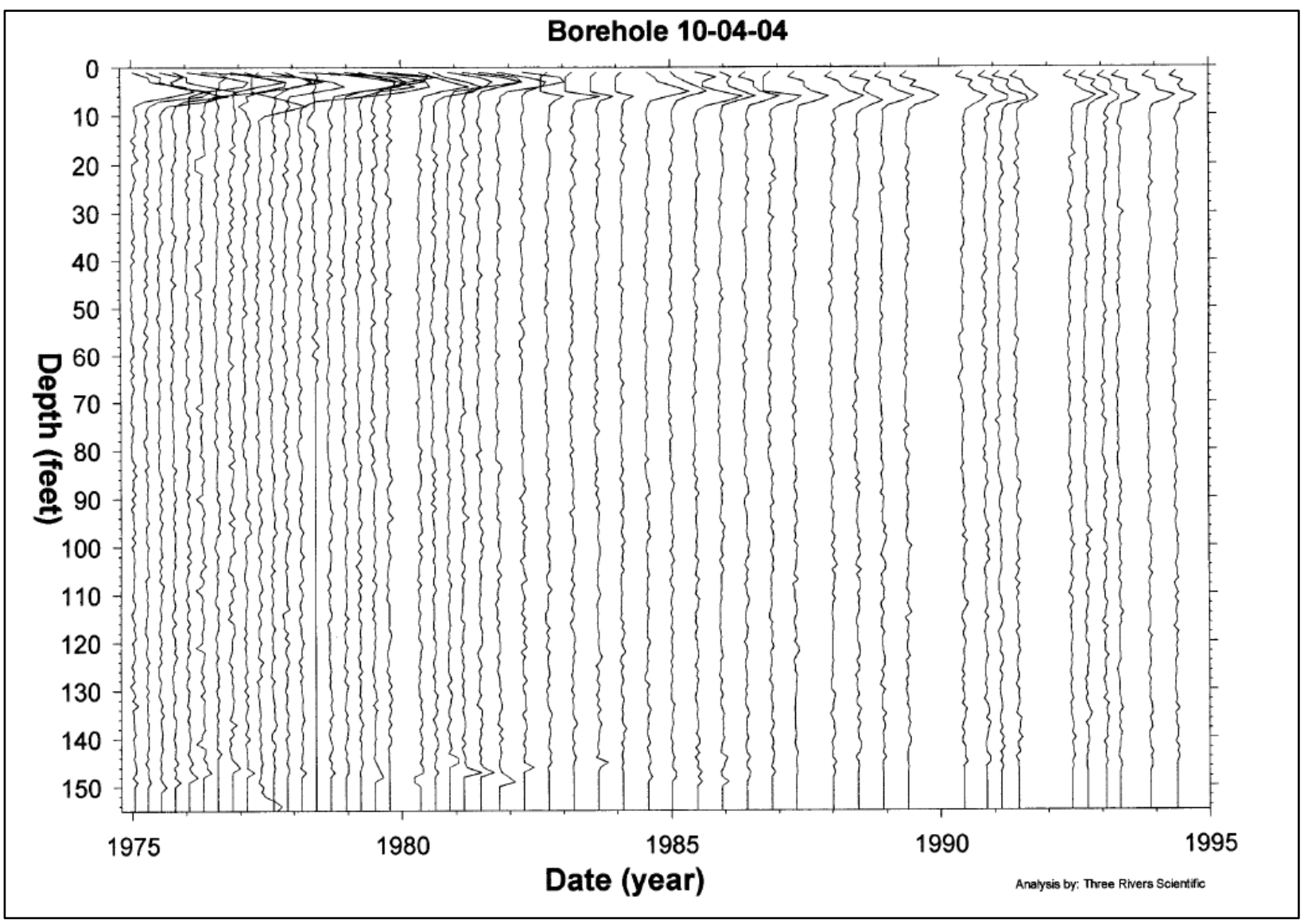

Note: Bottom of the tank footing is $\sim 47-\mathrm{ft} 10$-in BGS 


\subsubsection{Drywell 10-04-05}

Drywell 10-04-05 was drilled in April 1962 with the first recoverable reading on January 7, 1965 with three peak readings of 7, 8, and $18 \mathrm{cpm}$ at 50, 70, and 75-ft BGS, respectively (see Appendix D1). Radiation levels remained relatively stable through November 1965. The next recoverable reading was on September 13, 1972 and reported as less than values at this time through June 1986.

In August 1998, Cs-137 was the only man-made radionuclide detected in drywell 10-04-05 and was detected continuously from the ground surface to 15-ft BGS at concentrations ranging from 0.2 to $5 \mathrm{pCi} / \mathrm{g}$ (GJ-HAN-109). Low-level Cs-137 contamination was also detected from 24 to 28-ft BGS, from 49 to 75-ft BGS, and at the bottom of the drywell from 121.5-ft to 123-ft BGS. The maximum Cs-137 concentration was 5 pCi/g at 1-ft BGS. Document GJ-HAN-109 reports, "Shape factor results support the interpretation that the Cs-137 contamination detected between the ground surface and $5 \mathrm{ft}$ probably resulted from a surface spill that migrated down into the shallow backfill surrounding the borehole. The contamination from 5 to $15 \mathrm{ft}$ and 41 to $75 \mathrm{ft}$ was probably dragged down during the borehole extension activities." Therefore, drywell 10-04-05 is not included as part of the leak location for tank A-104. Figure 4-15 shows the depths of radioactivity from 1975 to 1995 (RPP-8820).

Figure 4-15. Tank A-104 Drywell 10-04-05 (RPP-8820)

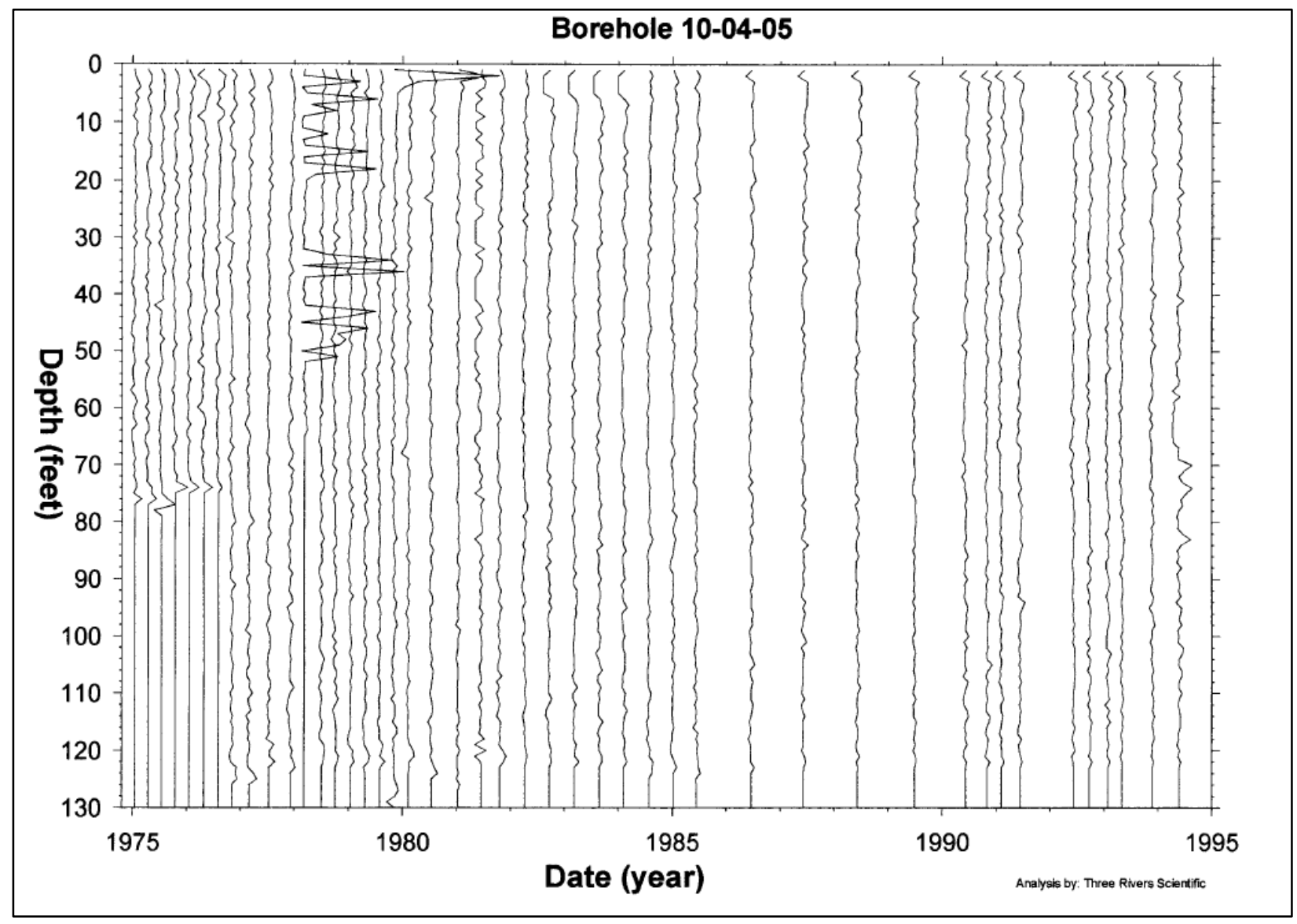

Note: Bottom of the tank footing is $\sim 47$-ft 10-in BGS 


\subsubsection{Drywell 10-04-07}

Drywell 10-04-07 was drilled in May 1962 with the first recoverable reading on October 28, 1965 with three peak readings of 5, 5, and $8 \mathrm{cpm}$ at 50, 73, and 75-ft BGS, respectively (see Appendix D1). Radiation levels remained relatively stable through January 1966. The next recoverable reading was on September 13, 1972 and reported as less than values at this time through June 1986.

In August 1998, Cs-137 was the only man-made radionuclide detected in drywell 10-04-07 (GJHAN-109). From the ground surface to 6-ft BGS, Cs-137 concentrations were recorded continuously at concentrations between 0.3 to $10.5 \mathrm{pCi} / \mathrm{g}$, intermittently from 14 to $19-\mathrm{ft} \mathrm{BGS}$ at concentrations just above the minimum detection limit (MDL), at an isolated occurrence at 34-ft BGS at MDL, and intermittently from 120 to $125-\mathrm{ft}$ BGS at concentrations below $1 \mathrm{pCi} / \mathrm{g}$. Document GJ-HAN-109 reports, "The Cs-137 concentration detected between the ground surface and 5-ft probably resulted from a surface spill that migrated down into the shallow backfill surround the borehole. The majority of the contamination detected below this zone was probably dragged down during the borehole extension activity." Therefore, drywell 10-04-07 is not included as part of the leak location for tank A-104. Figure 4-16 shows the depths of radioactivity from 1975 to 1995 (RPP-8820).

Figure 4-16. Tank A-104 Drywell 10-04-07 (RPP-8820)

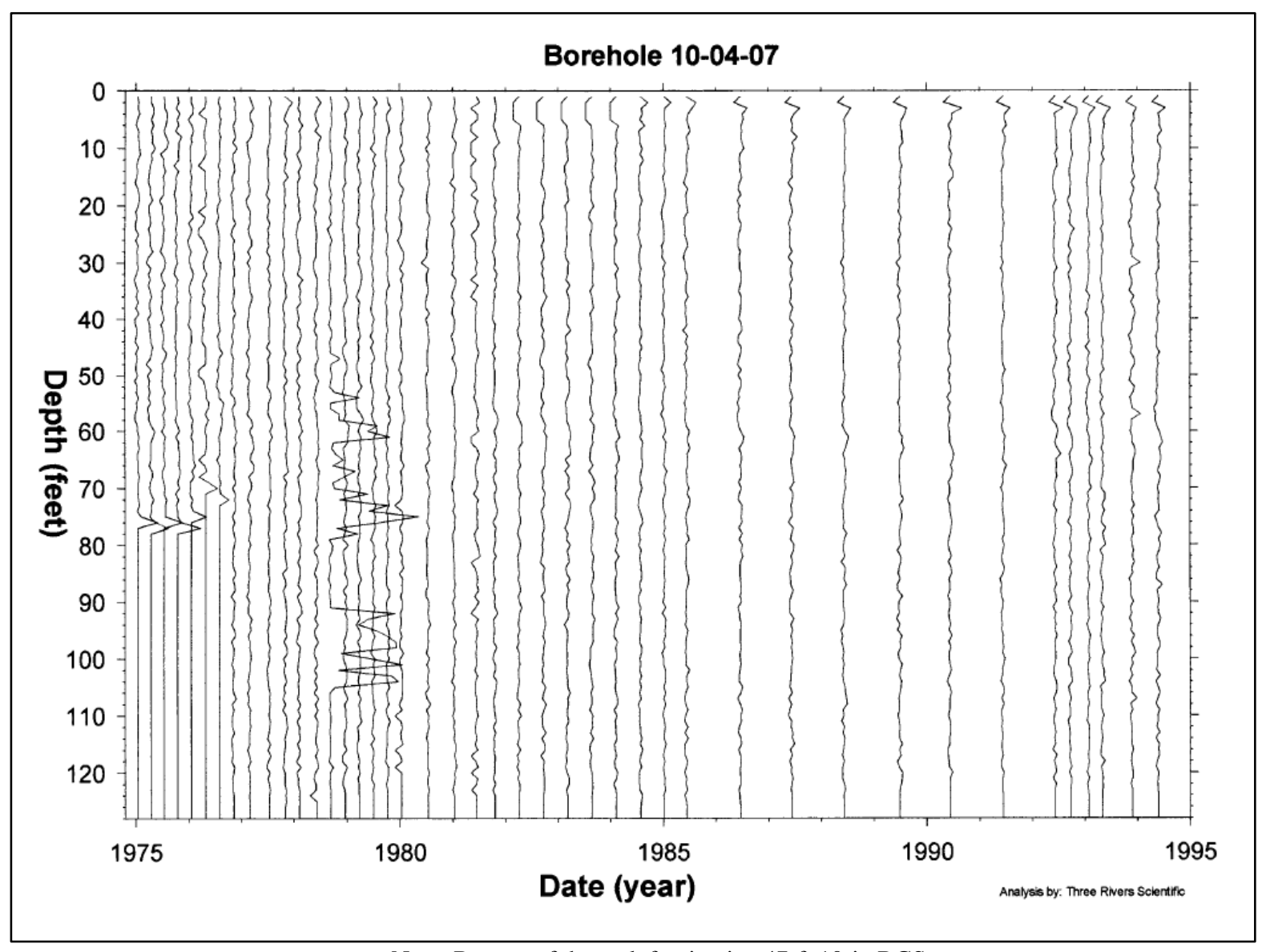

Note: Bottom of the tank footing is 47 -ft 10-in BGS 


\subsubsection{Drywell 10-04-08}

Drywell 10-04-08 was drilled in May 1962 with the first recoverable reading on November 3, 1965 with two peak readings of 6 and $8 \mathrm{cpm}$ at 60 and 75-ft BGS, respectively (see Appendix D1). Radiation levels remained relatively stable through January 1966. The next recoverable reading was on September 13, 1972 and reported as less than values at this time through June 1986.

In August 1998, Cs-137 was the only man-made radionuclide detected in drywell 10-04-08 (GJHAN-109). From the ground surface to $19-\mathrm{ft}$ BGS and from 20 to 30.5-ft BGS, Cs-137 concentrations were detected. From 1 to 4 -ft BGS, Cs-137 concentrations ranged from 1 to 20 pCi/g, approximately $1 \mathrm{pCi} / \mathrm{g}$ from 4 to $19-\mathrm{ft} \mathrm{BGS}, 0.3$ to $5 \mathrm{pCi} / \mathrm{g}$ from 26 to 28 -ft BGS, and 0.2 pCi/g from 55 to 70.5 -ft BGS and 81 to 81.5-ft BGS. Document GJ-HAN-109 reports, "the Cs137 contamination detected between the ground surface and $10 \mathrm{ft}$ probably resulted from a surface spill that migrated down into the backfill material surrounding the borehole. The majority of the contamination detected below this zone was probably dragged down during the borehole extension activity"....and, "The Cs-137 contamination detected from 55 to $70 \mathrm{ft}$ occurs at the base of the tank; this contamination may be the result of a tank leak, but the Cs-137 concentration is too low to interpret this with confidence." Therefore, drywell 10-04-08 is not included as part of the leak location for tank A-104. Figure 4-17 shows the depths of radioactivity from 1975 to 1995 (RPP-8820).

Figure 4-17. Tank A-104 Drywell 10-04-08 (RPP-8820)

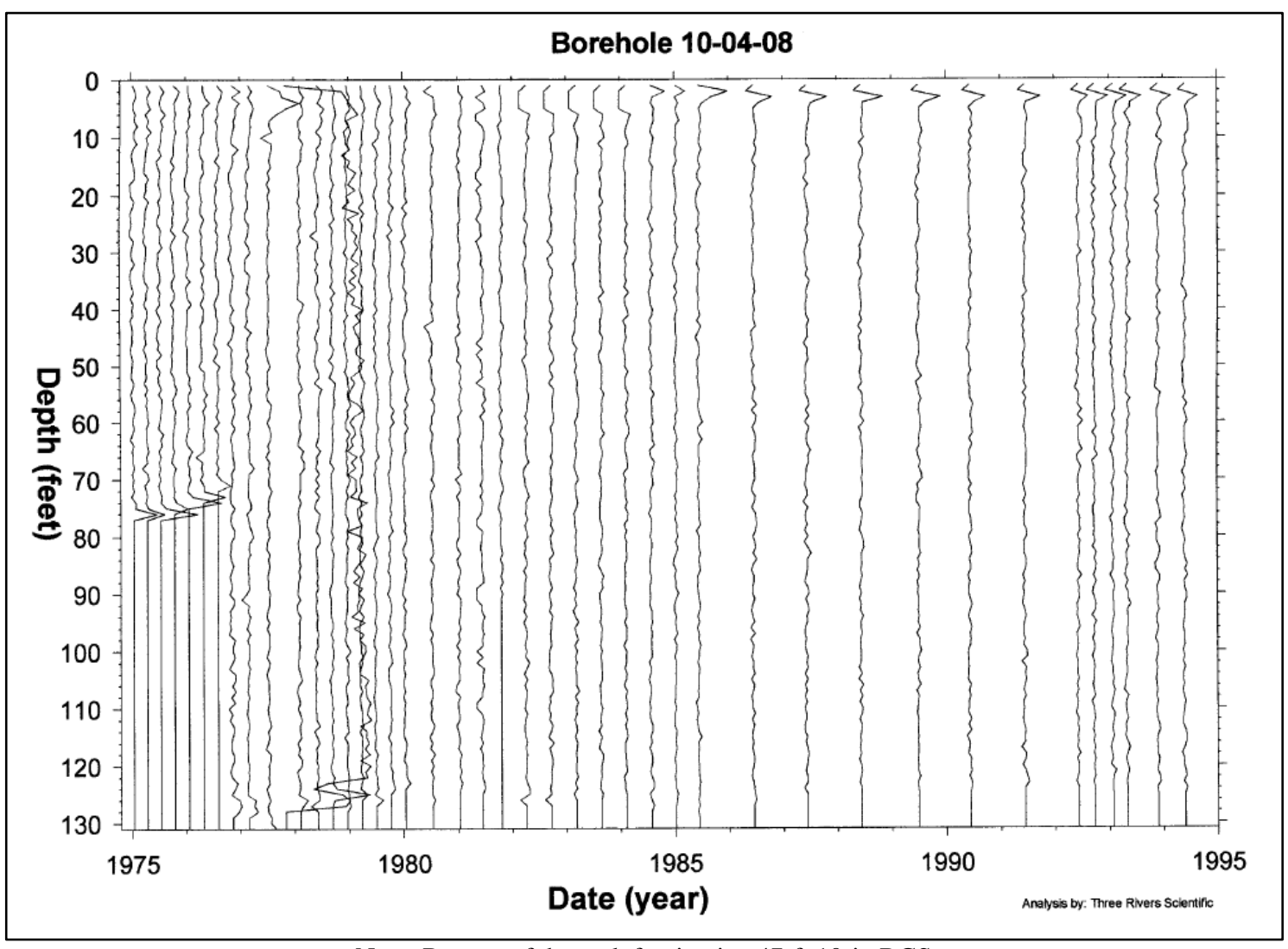

Note: Bottom of the tank footing is $\sim 47$-ft 10-in BGS 


\subsubsection{Drywell 10-04-10}

Drywell 10-04-10 was drilled in May 1962 with the first recoverable reading on November 3, 1965 with two peak readings of 6 and $8 \mathrm{cpm}$ at 50 and $75-\mathrm{ft}$ BGS, respectively (see Appendix D1). Radiation levels remained relatively stable through January 1966. The next recoverable reading was on September 13, 1972 and reported as less than values at this time through June 1986.

In August 1998, Cs-137 was the only man-made radionuclide detected in drywell 10-04-10 (GJHAN-109). From the ground surface to 6-ft BGS, Cs- 137 concentrations were detected continuously at concentrations ranging from 0.3 to $1.5 \mathrm{pCi} / \mathrm{g}$ and intermittently from 6 to $9.5-\mathrm{ft}$ BGS at approximately $0.2 \mathrm{pCi} / \mathrm{g}$. Isolated detections occurred at $50.5-\mathrm{ft}$ BGS and at the bottom of the drywell at $0.3 \mathrm{pCi} / \mathrm{g}$. Document GJ-HAN-109 reports, "The Cs-137 contamination detected between the ground surface and $6 \mathrm{ft}$ probably resulted from a surface spill that migrated down into the shallow backfill surrounding the borehole, and at least some of the contamination was dragged down during the borehole extension activity." Therefore, drywell 10-04-10 is not included as part of the leak location for tank A-104. Figure 4-18 shows the depths of radioactivity from 1975 to 1995 (RPP-8820).

Figure 4-18. Tank A-104 Drywell 10-04-10 (RPP-8820)

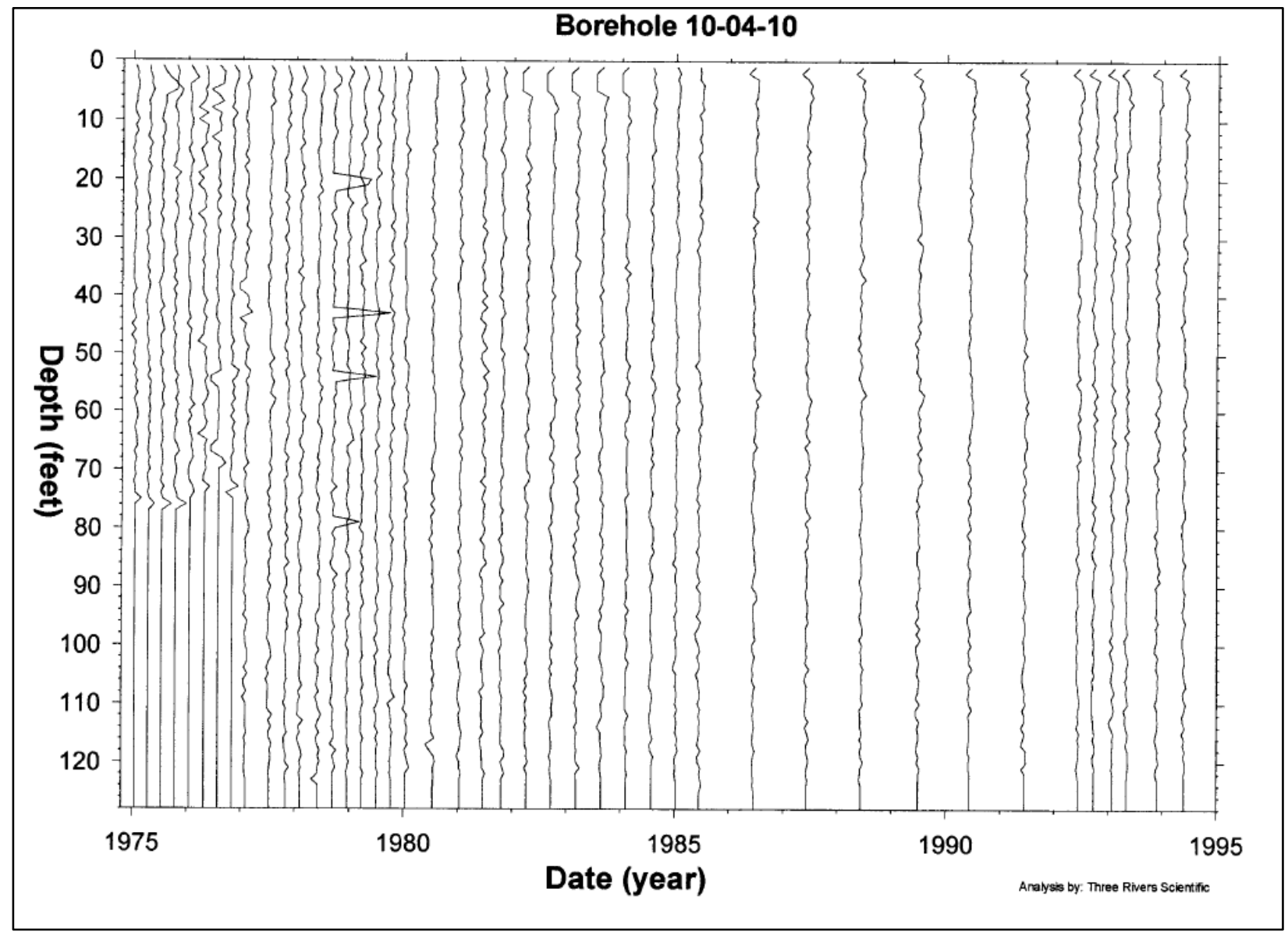

Note: Bottom of the tank footing is $\sim 47$-ft 10 -in BGS 


\subsubsection{Drywell 10-04-12}

Drywell 10-04-12 was drilled in May 1962 with the first recoverable reading on January 3, 1965 with three peak readings of 600, 7 and $12 \mathrm{cpm}$ at 6, 50 and 75-ft BGS, respectively (see Appendix D1). Radiation levels remained relatively stable through January 1966. The next recoverable reading was on September 13, 1972 and reported as less than values at this time through June 1986.

In August 1998, Cs-137, Co-60, and Eu-154 were the only man-made radionuclides detected in drywell 10-04-12 (GJ-HAN-109). From the ground surface to 9-ft BGS, Cs-137 contamination was detected continuously at concentrations ranging from $0.3 \mathrm{pCi} / \mathrm{g}$ to $16 \mathrm{pCi} / \mathrm{g}$. From 9 to $15.5-$ $\mathrm{ft}$ BGS, Cs-137 was also detected intermittently at concentrations just above the minimum detection limit and from 70.5 to 72.5 -ft BGS at concentrations less than $0.3 \mathrm{pCi} / \mathrm{g}$. From 7.5 to 8.5-ft BGS, Co-60 was detected continuously at concentrations ranging from 0.1 to $0.3 \mathrm{pCi} / \mathrm{g}$. From 7 to 8.5 -ft BGS, Eu-154 was detected continuously at concentrations ranging from 0.5 to $1.5 \mathrm{pCi} / \mathrm{g}$. Document GJ-HAN-109 reports, "There is no indication of elevated gamma readings in data collected from this borehole that could be attributed to subsurface contamination." Therefore, drywell 10-04-12 is not included as part of the leak location for tank A-104. Figure 4-19 shows the depths of radioactivity from 1975 to 1995 (RPP-8820).

Figure 4-19. Tank A-104 Drywell 10-04-12 (RPP-8820)

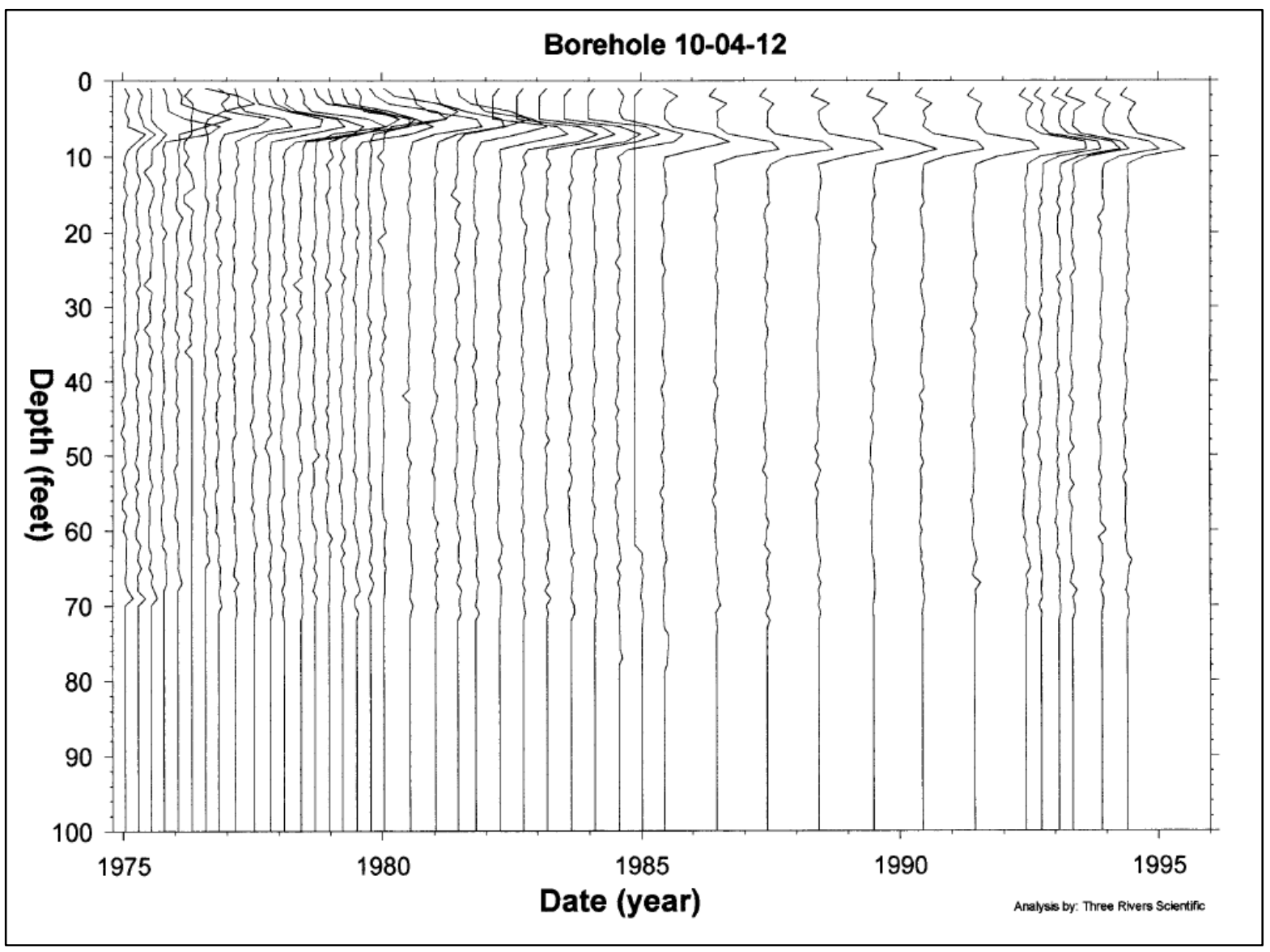

Note: Bottom of the tank footing is $~ 47-\mathrm{ft} 10$-in BGS 


\subsubsection{Drywell Summary}

Tank A-104 was first suspected of leaking in March 1975 due to radioactivity being detected in lateral 14-04-02 in the northern portion of tank A-104 (see Section 4.5.1). During this time, no drywells were reported to have increased radioactivity levels.

Tank A-104 drywells 10-04-01, 10-05-09, 10-04-04, 10-04-05, 10-04-07, 10-04-08, 10-04-10, and 10-04-12 do not indicate any radioactivity associated with a tank A-104 leak. Therefore, these drywells are not included in the leak location analysis for tank A-104.

\subsection{POSSIBLE TANK A-104 LINER LEAK LOCATION(S)}

The lateral radioactivity when first detected could be an indication of the location of a liner leak. However, the liner leak may have penetrated the waterproof membrane at any location or pooled on the waterproof membrane and followed concrete cracks or breaks to a different location including the top of the tank footing.

It is likely that the majority of the tank A-104 leak occurred at the tank footing because all of the indicators, three laterals, were located at or near the tank footing. The liquid level was reported at 31-in at the end of February 1975, shortly before tank A-104 was first suspected of leaking. Therefore, it is likely the leak site or sites are located below the 31-in waste level. 


\subsubsection{Leak Detected in March 1975}

Tank A-104 was first suspected of leaking on March 18, 1975 shortly after the start of sluicing the tank in September 1974 due to radioactivity being detected in lateral 14-04-02 in the northern portion of the tank (see site A in Figure 4-20). The peak radioactivity was reported at $100 \mathrm{cpm}$ in lateral 14-04-02 at approximately $94-\mathrm{ft}$ from the caisson. No radioactivity indicative of a tank A-104 leak was detected in the drywells or other laterals during this time. Tank A-104 liquid level was reported at 31-in at the end of February 1975; therefore, it is likely the leak location was below this waste level.

Figure 4-20. Tank A-104 Possible Leak Location (March 1975)

Tank inner ring is steel liner; outer ring is outer edge of tank footing

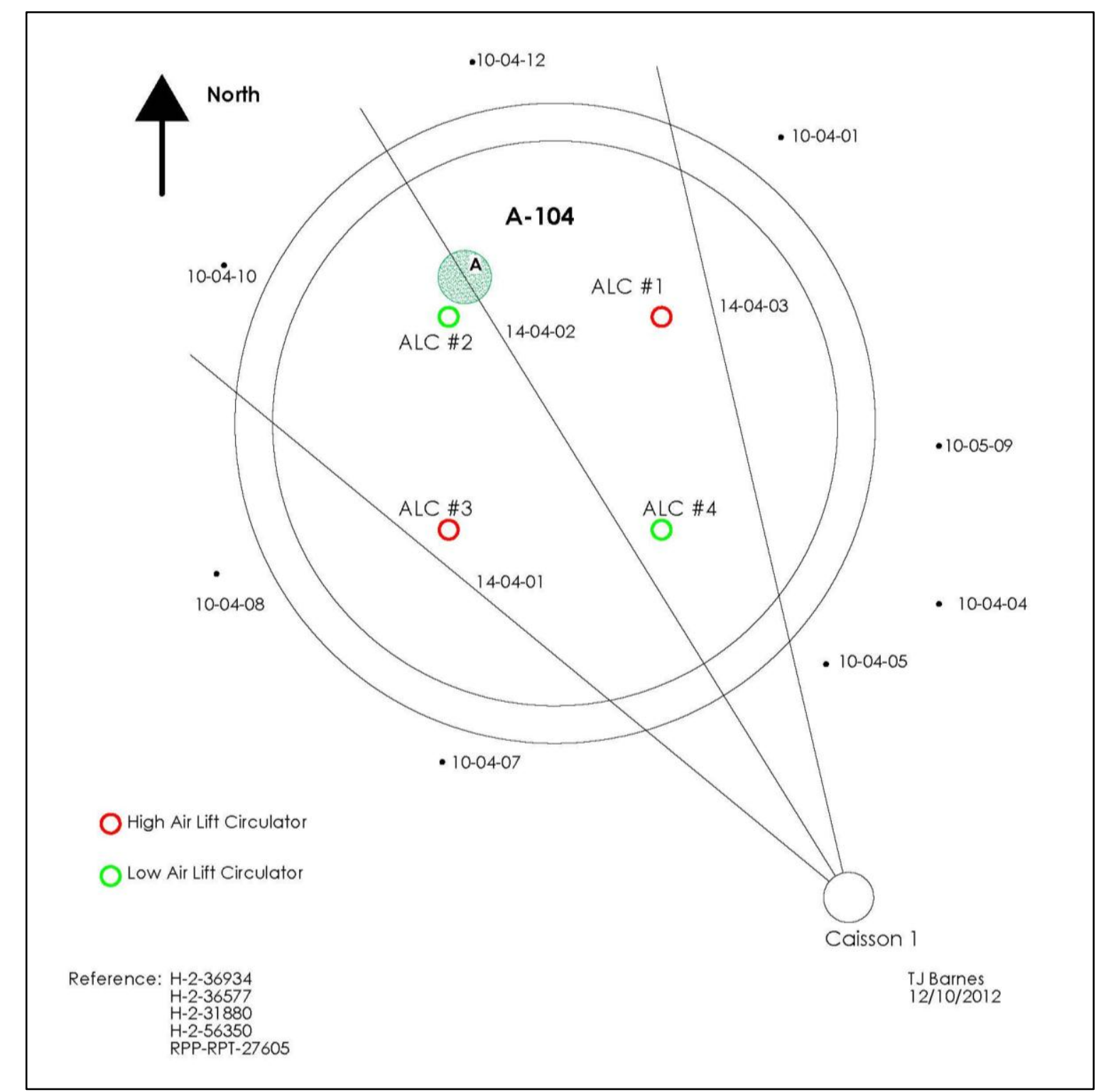

Tank A-104 was first suspected of leaking in March 1975 due to radioactivity being detected in lateral 14-04-02 in the northern portion of the tank. 


\subsubsection{Leak Detected in April 1975}

A week after the initial radioactivity was detected in lateral 14-04-02, counts continued to increase at site A (see Figure 4-20) and sluicing was halted on April 7, 1975. The following day on April 8, 1975, radioactivity was first detected in lateral 14-04-01 and an additional peak was recorded in lateral 14-04-02, both in the southern portion of the tank (see site B in Figure 4-21). Laterals were then monitored daily throughout April 1975 and radioactivity continued to increase in laterals 14-04-01 and 14-04-02 during the month. On April 21, 1975, radioactivity was first reported in lateral 14-04-03 along the northeast edge of the tank. Tank A-104 was declared a confirmed leaker in April 1975 and supernatant was pumped out of the tank from April 9 through April 19, 1975.

Figure 4-21. Tank A-104 Leak Indication (April 1975)

Tank inner ring is steel liner; outer ring is outer edge of tank footing

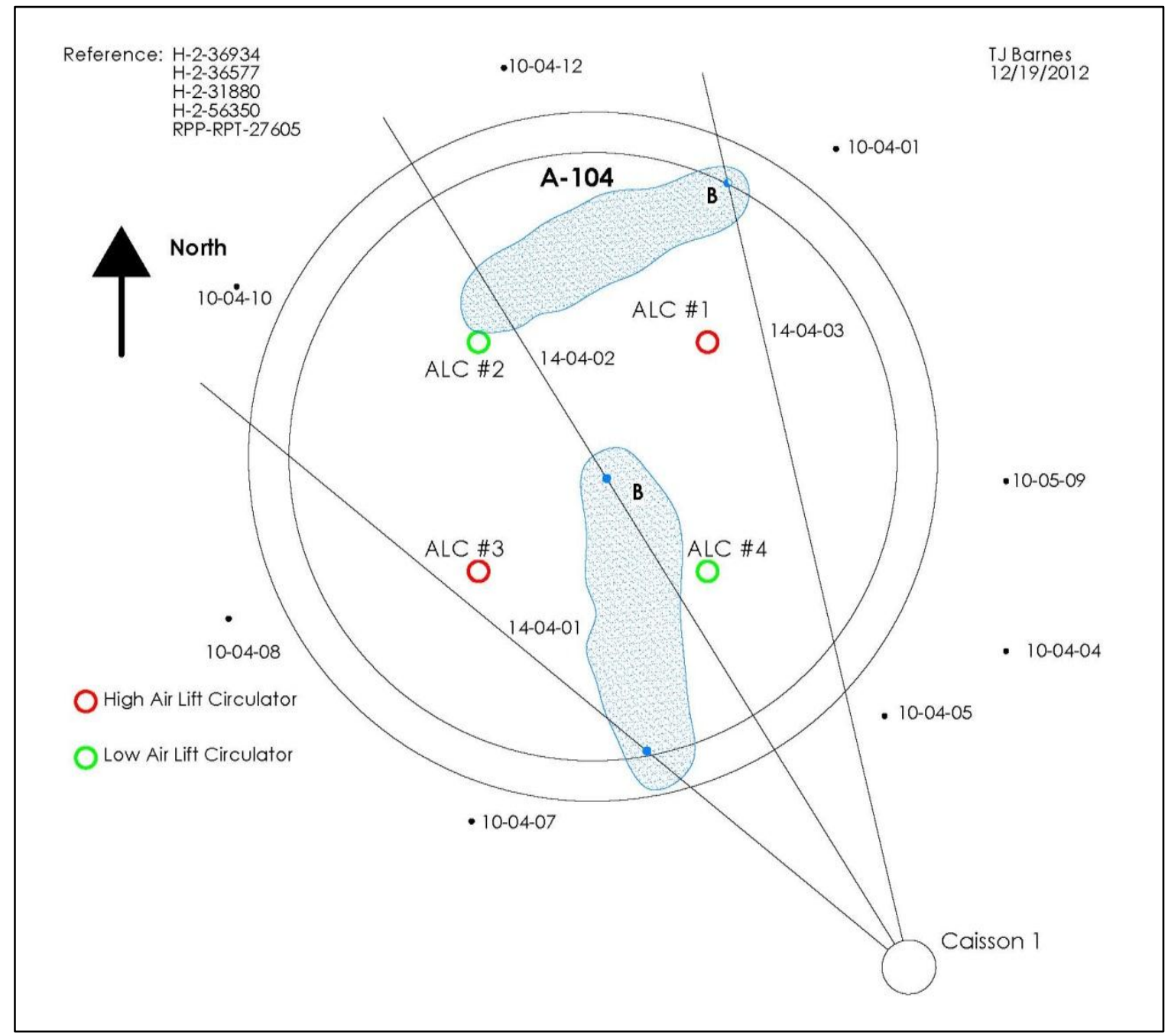

Tank A-104 was first suspected of leaking in March 1975 due to radioactivity being detected in lateral 14-04-02 in the northern portion of the tank. 


\subsubsection{Leak Detected in May 1975}

In May 1975, additional peaks were detected in lateral 14-04-02 at 47-ft from the caisson and in lateral 14-04-01 at 45-ft from the caisson (see site $\mathrm{C}$ in Figure 4-22). Radioactivity in lateral 1404-01 at site B in Figure 4-21 continued to slowly increase through June 1975. Radioactivity in lateral 14-04-02 at site B in Figure 4-21 continued to slowly increase through October 1975. Radioactivity in lateral 14-04-03 slowly increased in May 1975 at site B in Figure 4-21, and then slowly declined through October 1975. No additional peaks were reported for lateral 14-04-03 in 1975. The tank A-104 liquid level was reported at 6.5-in at the end of April 1975 and radioactivity in the laterals appeared to stabilize by the end of 1975 . No radioactivity that could be indicative of a tank A-104 leak was detected in the drywells during this time.

Figure 4-22. Tank A-104 Leak Indicators (May 1975)

Tank inner ring is steel liner; outer ring is outer edge of tank footing

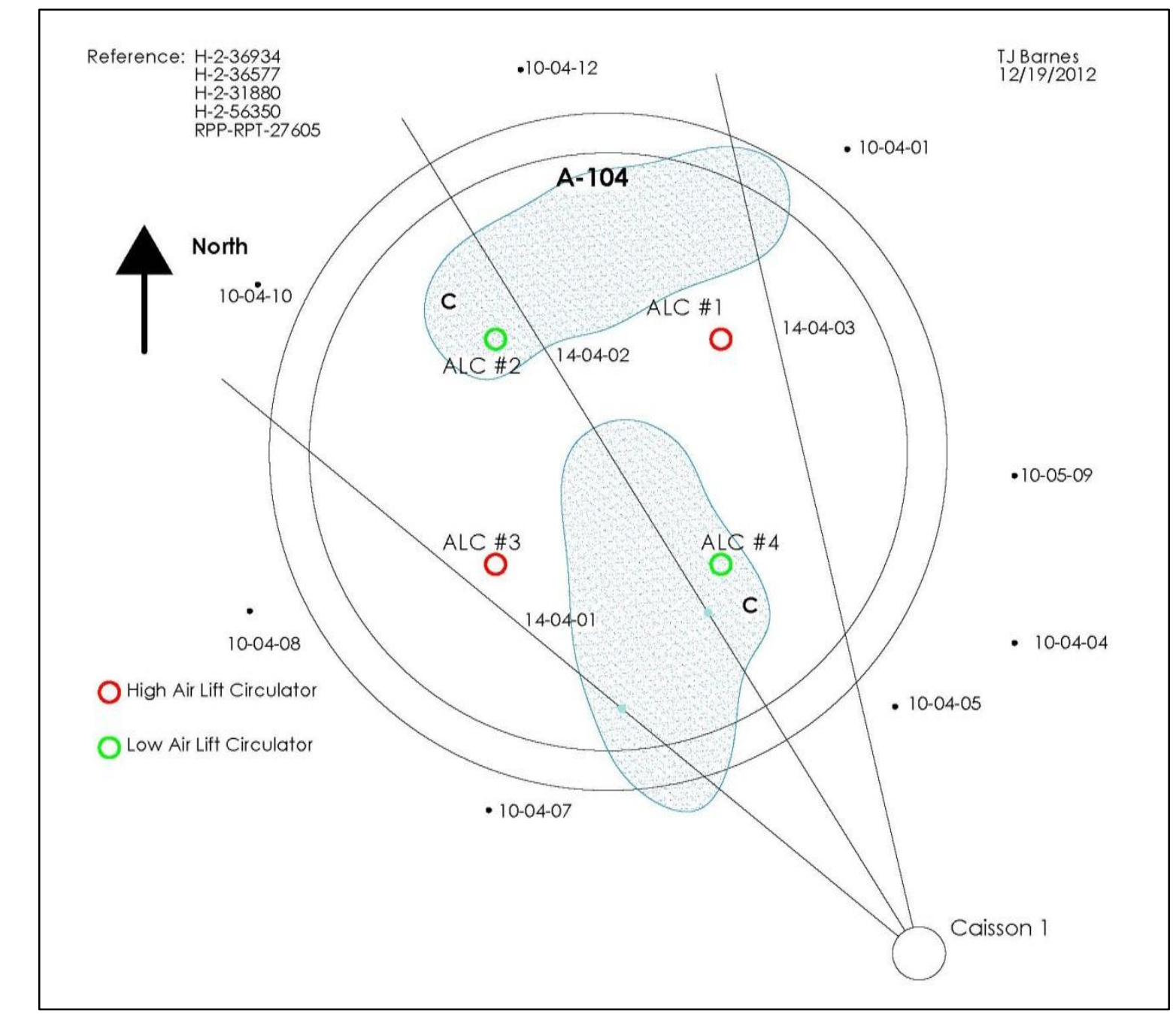

Tank A-104 was first suspected of leaking in March 1975 due to radioactivity being detected in lateral 14-04-02 in the northern portion of the tank. 
RPP-RPT-54912, Rev. 0

\subsubsection{Leak Location Summary}

Tank A-104 was first suspected of leaking on March 18, 1975 due to radioactivity being detected in lateral 14-04-02 in the northern portion of the tank shortly after the start of sluicing in September 1974 (see site A in Figure 4-20). Radioactivity continued to increase in lateral 14-0402 at site A; therefore, sluicing was halted on April 7, 1975.

The following day on April 8, 1975, additional radiation peaks were recorded, one in lateral 1404-01 and one in lateral 14-04-02, both along the southeast edge of the tank (see site B in Figure 4-21). Laterals were then monitored daily throughout April 1975 and radioactivity continued to increase in laterals 14-04-01 and 14-04-02 during the month. Tank A-104 was declared a confirmed leaker in April 1975 and supernatant was pumped out of the tank from April 9 through April 19, 1975. On April 21, 1975, radioactivity was first reported in lateral 14-04-03 along the northeast edge of the tank.

In May 1975, additional peaks were detected in laterals 14-04-01 and 14-04-02 along the southeastern edge of the tank (see site $\mathrm{C}$ in Figure 4-22). Radioactivity peaks located at site B in Figure 4-21 for laterals 14-04-01 and 14-04-02 continued to slowly increase through 1975. However, no additional radioactivity peaks were reported in lateral 14-04-03 and radioactivity reported at site B (see Figure 4-21) began to slowly decline in May 1975.

Leak locations in Figure 4-23 are based on peak readings and are a representation of possible initial and subsequent boundaries of radioactivity. It is likely the leak site or sites are located below the 31-in waste level as the tank A-104 liquid level was reported at 31-in at the end of February 1975, shortly before the tank was first suspected of leaking.

No records were found in available documents for a liner bulge occurring in tank A-104, and it remains unclear if a liner bulge once existed in the tank during its operation. After reviewing available in-tank photographs, there is a possibility of a liner bulge as indicated by ALCs \#1 through \#4 (see Section 4.4.5). However, a liner bulge remains inconclusive for tank A-104. 
Figure 4-23. Tank A-104 Possible Radial Leak Locations and Indicators Tank inner ring is steel liner; outer ring is outer edge of tank footing

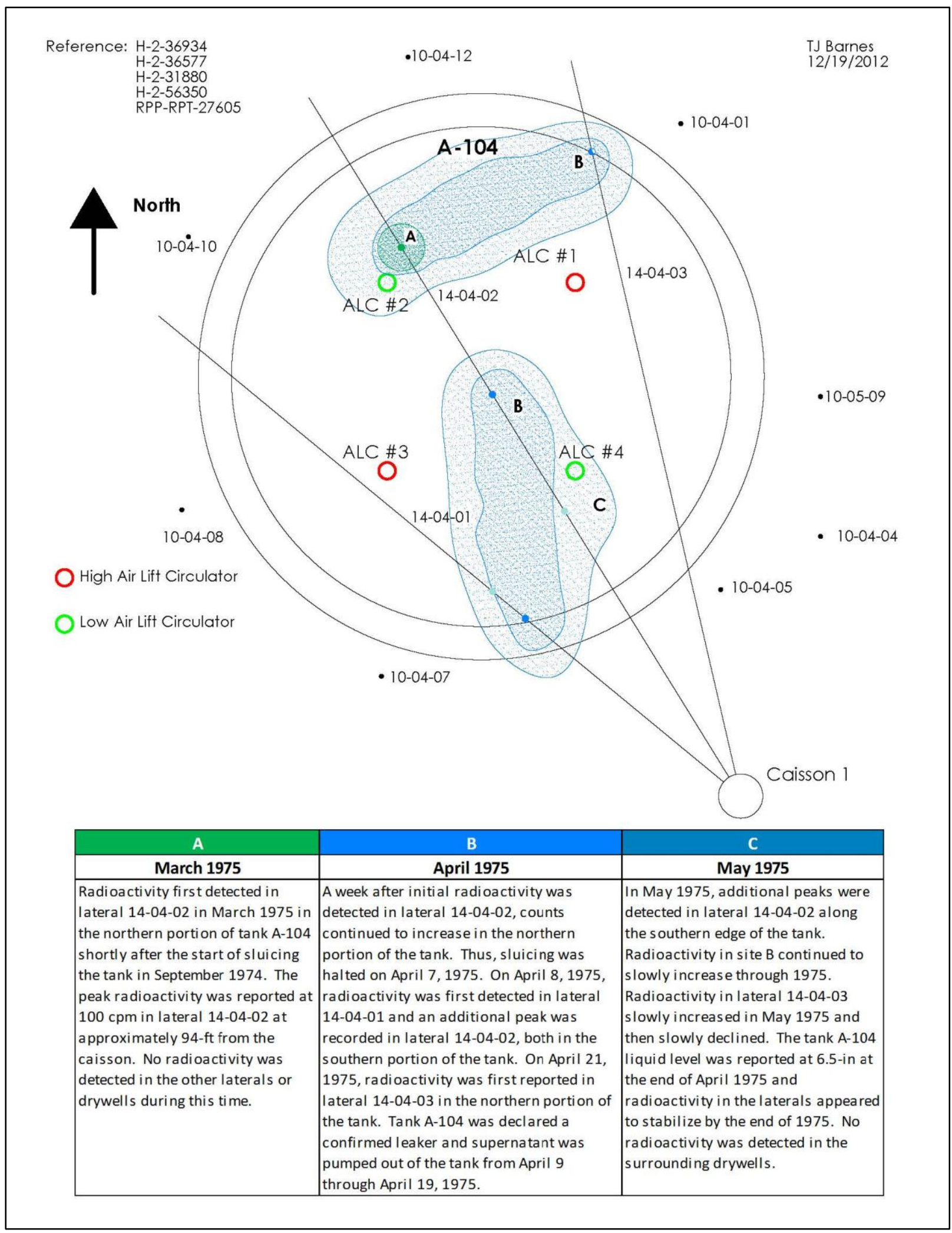


RPP-RPT-54912, Rev. 0

\subsection{POSSIBLE TANK A-104 LINER LEAK CAUSE(S)}

Tank A-104 was evaluated for five conditions known to contribute to a failed liner.

\subsubsection{Tank Design}

The design of the A Farm tanks was the second, after 241-SX Farm, that diverged from the round bottom knuckle design used in the earlier waste tanks. The flat tank bottom liner intersects the sidewall liner orthogonally. A fillet weld was used to close the seam where the sidewall and tank bottom liners meet. Several other SSTs with fillet welds failed during service (RPP-RPT-45921, Single Shell Tank Integrity Expert Panel Report). Weld inspections were less rigorous. Additionally, the design discontinued the use of the three ply asphaltic membrane waterproofing between the liner and the concrete shell. These features were inferior compared to earlier tank designs and could possibly increase the likelihood of failure of the tank liner from induced stresses (see Section 3.1.1).

\subsubsection{Thermal Conditions}

Temperature requirements in HW-59919 issued October 22, 1959 indicated that the self-boiling waste operating temperature should be maintained between $220^{\circ} \mathrm{F}$ and $250^{\circ} \mathrm{F}$. The maximum sludge temperature should not exceed $300^{\circ} \mathrm{F}$.

The tank A-104 bulb (sludge) temperatures are shown in Appendix B1. The maximum temperature of tank A-104 reached approximately $437^{\circ} \mathrm{F}$ on February 16, 1963 which exceeded the maximum sludge temperature of $300^{\circ} \mathrm{F}$ and for approximately 17 months waste temperatures were recorded greater than $300^{\circ} \mathrm{F}$.

The HW-59919 document recommended a uniform rate of temperature increase of $2^{\circ} \mathrm{F}$ per day. Temperatures were recorded as approximately $257^{\circ} \mathrm{F}$ on January 2,1963 and gradually rose to $428^{\circ} \mathrm{F}$ by February 6,1963 ; the temperature rate of rise was therefore approximately $4.9^{\circ} \mathrm{F} / \mathrm{day}$. The highest temperature rate of rise as well as the maximum recorded temperature occurred in January/February 1963. During this time, tank A-104 contained PUREX HLW and OWW from PUREX was being periodically transferred into the tank. There were no other increases in temperatures that exceeded the average rate of rise of $4.9^{\circ} \mathrm{F} /$ day during the operation of tank A104. Exceeding the operating temperature requirements would create liner stress when thermally hot high level waste was received and stored in the tank especially without pre-heating. Tank A104 was pre-heated prior to receiving waste but the initial heat up rate of rise is not available therefore it is unknown if the initial temperature rate of rise exceeded the recommended temperature increase of $2^{\circ} \mathrm{F}$ per day.

Thermal shock creates stress both from rapid temperature rise as well as high temperatures.

\subsubsection{Chemistry-Corrosion}

Tank A-104 stored initial test water for approximately one year in 1957 prior to receiving waste. Subsequently at the end of calendar year 1969 after sluicing the tank A-104 solids leaving a solids heel of 8-in, $957 \mathrm{kgal}$ of water was transferred on top of this heel and was stored for 
approximately three years. It is possible some corrosion occurred during these periods as there is no mention of chemical adjustment to inhibit corrosion. However, it is assumed that water added to the tank during these two periods was raw water at a $\mathrm{pH}$ of approximately 7.8 (ERDA-1538) as this was common tank farm practice.

Waste type PSS is outside the chemistry limits for preventing SCC since the addition of the concentrations of nitrite and hydroxide are not greater than 1.2 M (see Section 4.4.4). Tank A-104 received PSS waste from 1972 to 1974, storing for approximately three years before the tank was first suspected of leaking in March 1975. The PSS waste could have created an environment conducive to SCC.

No additional conditions have been identified that could accelerate corrosion of the tank steel liner.

\subsubsection{Liner Observations}

The table in RHO-R-39 (see Appendix A1) indicated there was no bulge present when tank A104 was inspected for a bulge. The evidence of a liner bulge is possible in tank A-104 from all photographs, but not conclusive. Liner bulging coupled with other tank conditions could affect tank liner integrity; however, by itself bulging induces stresses that can cause breaching of the tank liner.

\subsubsection{Tank Construction Temperature}

The lowest average temperatures during construction of the A Farm tank liners occurred in December 1954 at $34^{\circ} \mathrm{F}$ and January 1955 at $30^{\circ} \mathrm{F}$ with four months having at least one minimum temperature between $14^{\circ} \mathrm{F}$ and $18^{\circ} \mathrm{F}$ (see Section 4.3.2). The low temperatures experienced during construction were less than the $18^{\circ} \mathrm{F}$ allowable temperature where impact loading had the potential for creating micro-fissures. Impact occurrences may have triggered fissures in the steel liner.

\subsection{TANK A-104 CONCLUSIONS}

Evidence indicates that the tank A-104 liner leaked at or near the tank footing. Based on engineering judgment and available information the following conditions contributed to the tank A-104 failed liner:

1. Thermal conditions - rate of temperature rise

2. Tank design - expansion limiting design

3. Water and PSS waste storage chemistry - corrosion - stress corrosion cracking

4. Construction conditions - ductile-to-brittle transition temperature

There are several liner leak cause conditions that were examined, but the primary cause is the tank A-104 thermal conditions. The design did not allow for expansion of the bottom liner as the tank heated which created stresses. Initial heat up rate of tank A-104 is not available but available data infer heat-up rates in excess of the allowable $2^{\circ} \mathrm{F} /$ day for periods of time; if the rate of rise was too high, grout moisture could have resulted in the vapor pressure under the liner 
increasing enough to cause a bulge in the tank bottom liner. The highest rate of rise during waste storage occurred in February 1963 at approximately $4.9^{\circ} \mathrm{F} /$ day. Temperature rate of rise could have set up stresses that may have weakened the tank bottom liner where other factors such as unmeasured bulging fluctuations and corrosion may have further compromised the liner. Tank A-104 experienced the third highest temperature of all tanks, however, tanks A-103 and A-106 were even higher and those tanks are categorized as sound.

Construction conditions could have also contributed to the tank bottom liner failure but to a lesser degree. 
RPP-RPT-54912, Rev. 0

\section{APPENDIX A1}

\section{TANK A-104 BOILING WASTE OPERATIONAL HISTORY}

A1-1 
Table A1-1. RHO-R-39 Boiling Waste Tank Operating Data Table

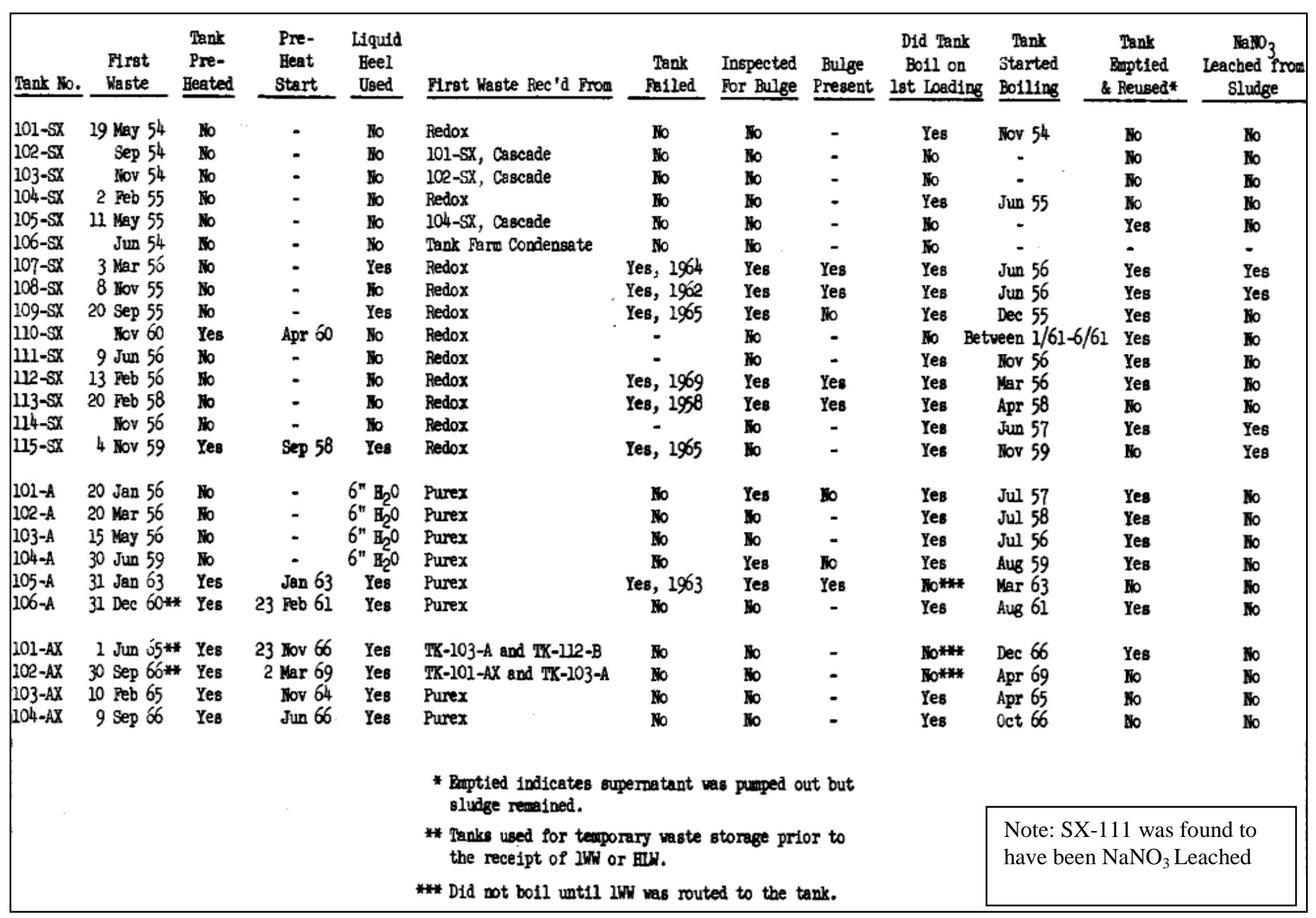


RPP-RPT-54912, Rev. 0

APPENDIX B1

TANK A-104 TEMPERATURES DECEMBER 1962-MARCH 1970

B1-1 
Figure B1-1. RHO-CD-1172 Tank A-104 Temperature December 1962 through April 1963

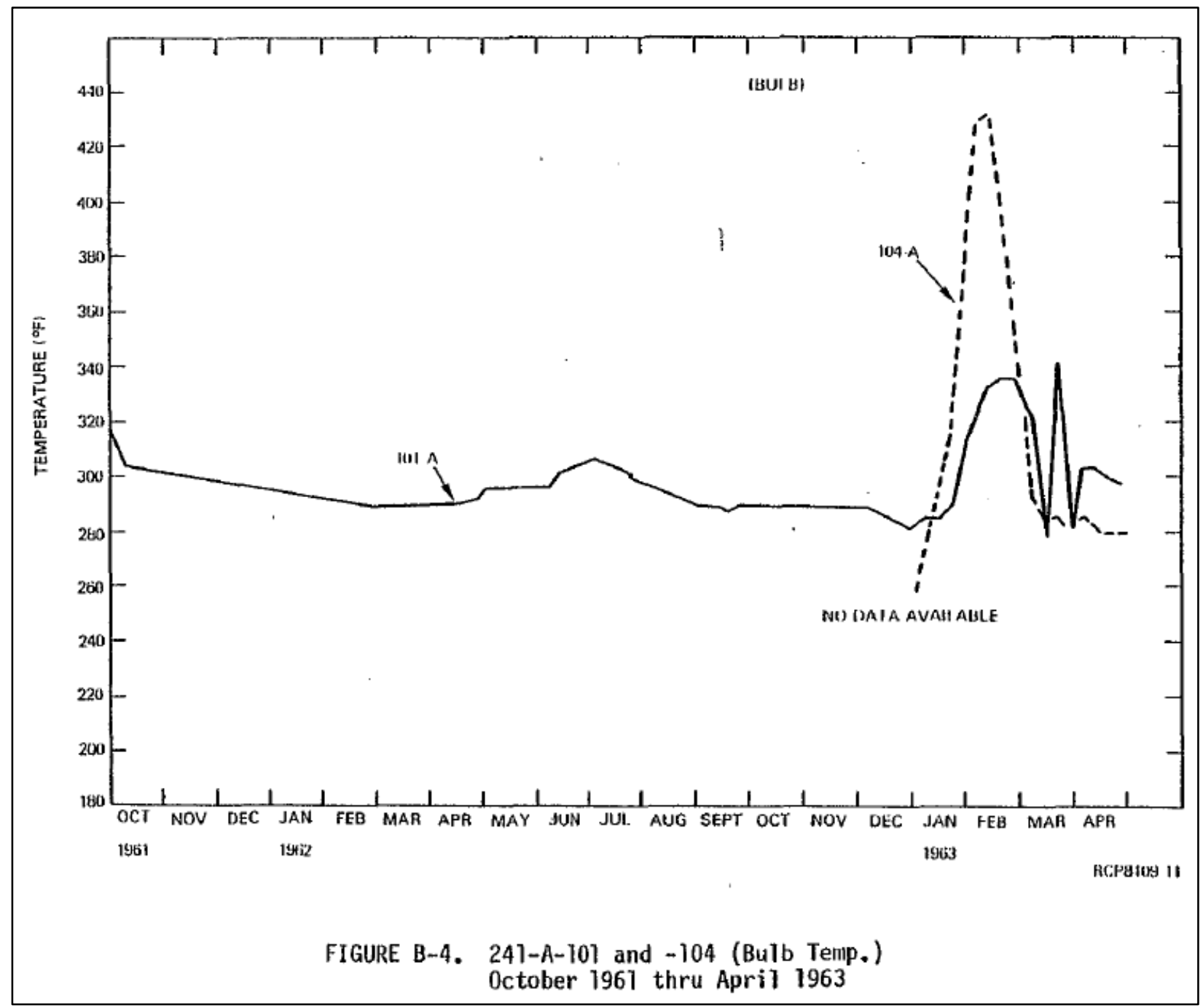

Note: Bulb (sludge) temperature 2-in to 3-in off the tank bottom (see Section 3.2.2) 
RPP-RPT-54912, Rev. 0

Figure B1-2. RHO-CD-1172 Tank A-104 Temperature May 1963 through November 1964

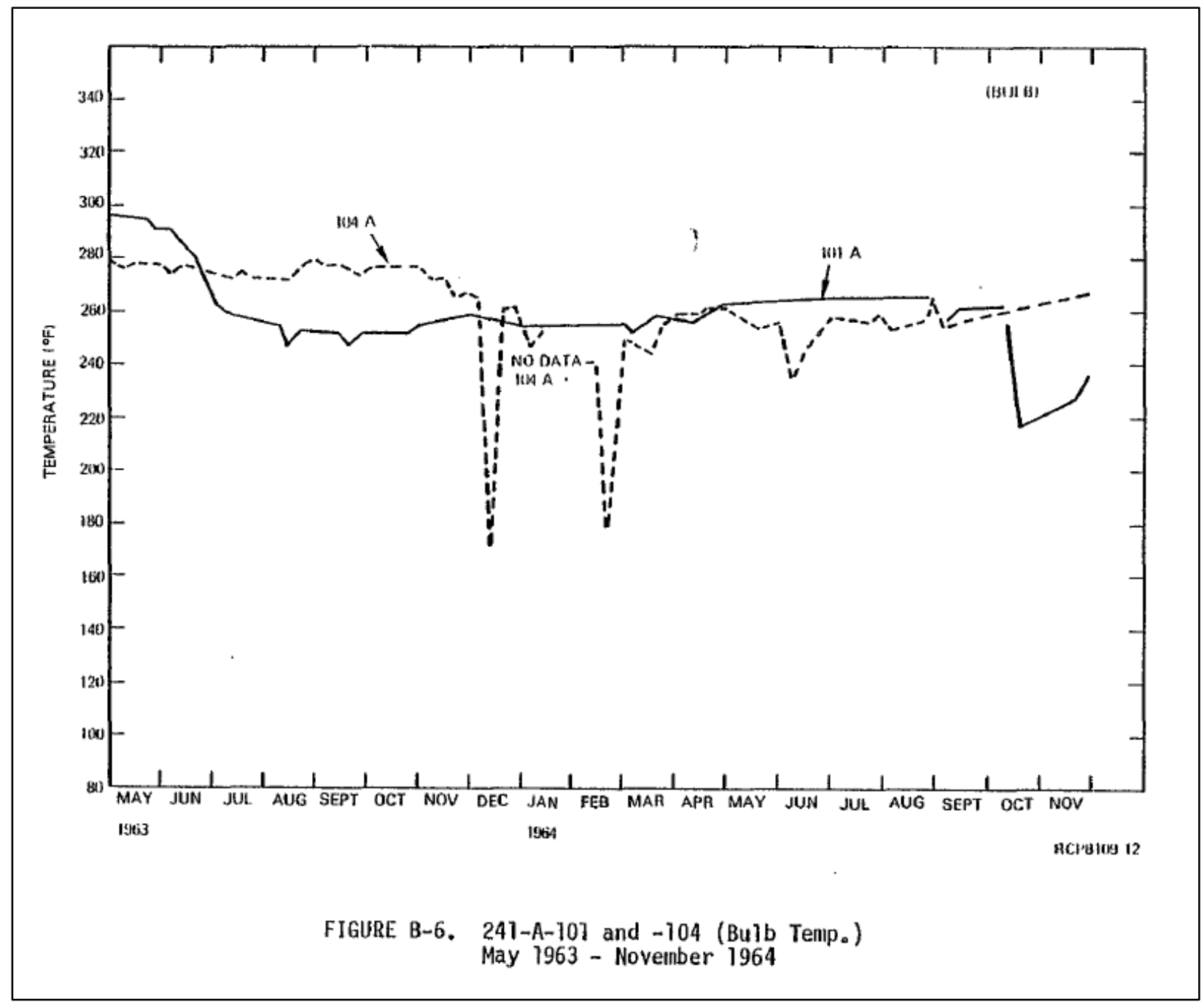

Note: Bulb (sludge) temperature 2-in to 3-in off the tank bottom (see Section 3.2.2) 
RPP-RPT-54912, Rev. 0

Figure B1-3. RHO-CD-1172 Tank A-104 Temperature December 1964 through June 1966

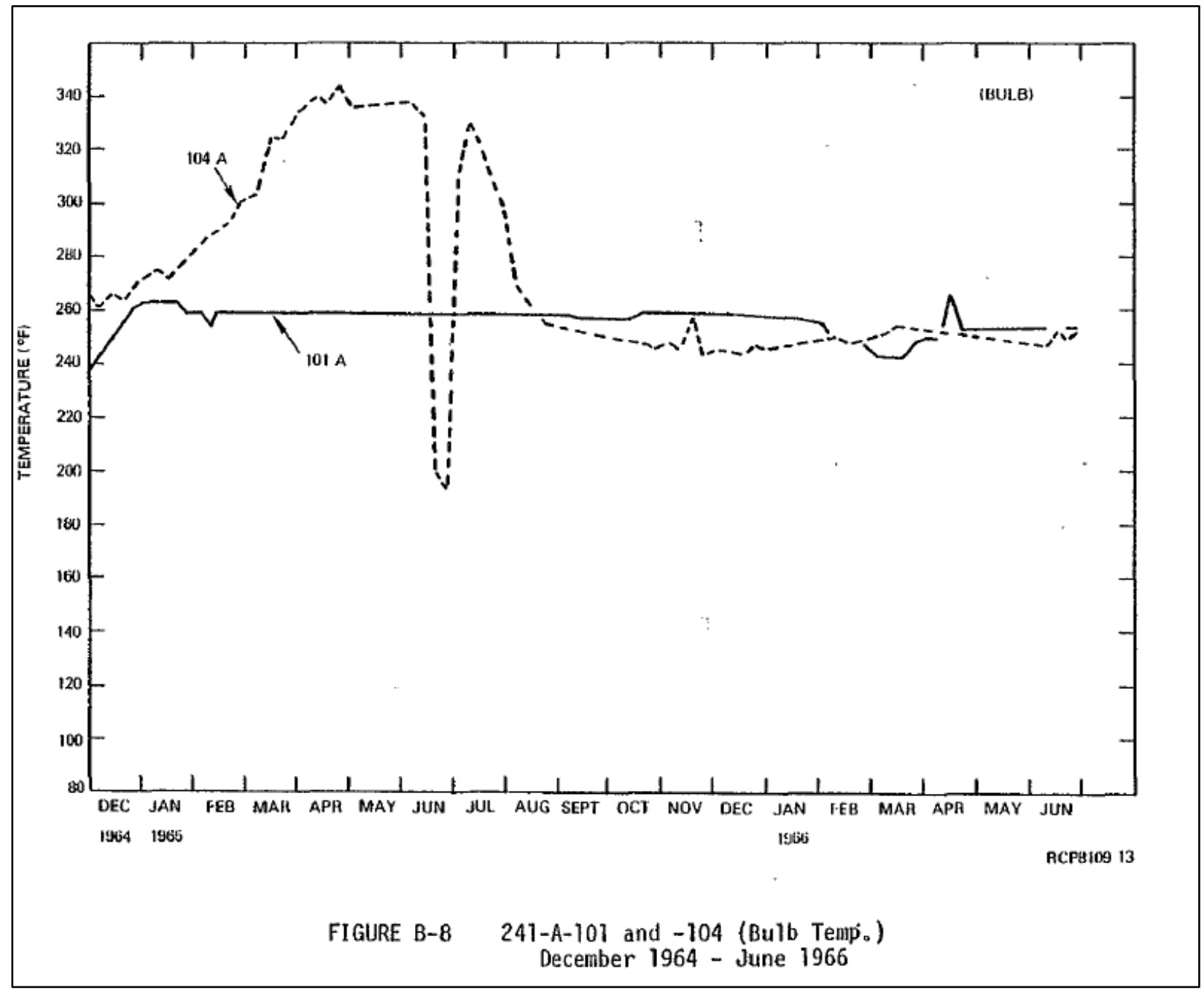

Note: Bulb (sludge) temperature 2-in to 3-in off the tank bottom (see Section 3.2.2) 
RPP-RPT-54912, Rev. 0

Figure B1-4. RHO-CD-1172 Tank A-104 Temperature July 1966 through January 1968

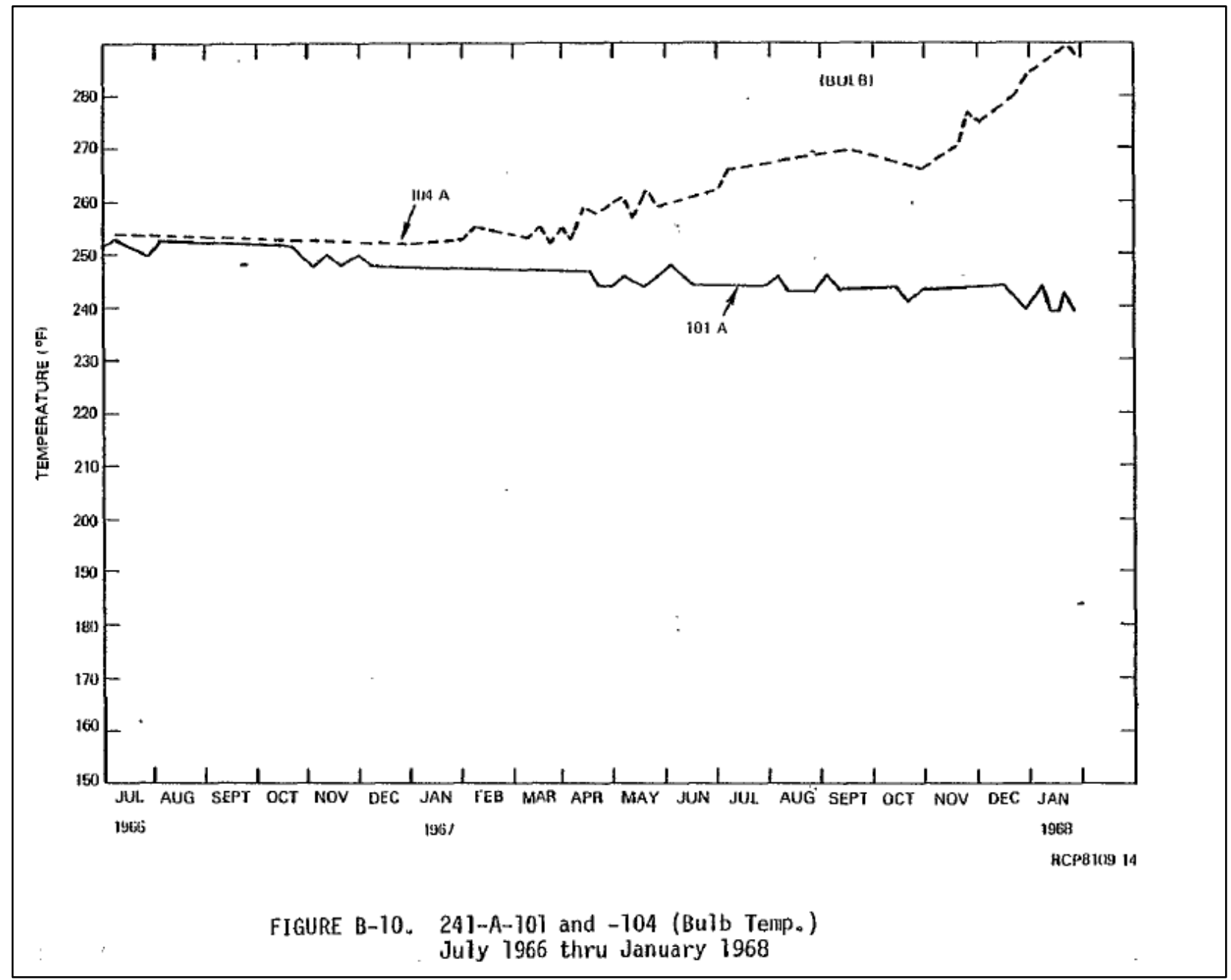

Note: Bulb (sludge) temperature 2-in to 3-in off the tank bottom (see Section 3.2.2) 
RPP-RPT-54912, Rev. 0

Figure B1-5. RHO-CD-1172 Tank A-104 Waste Temperature February 1968 through August 1969

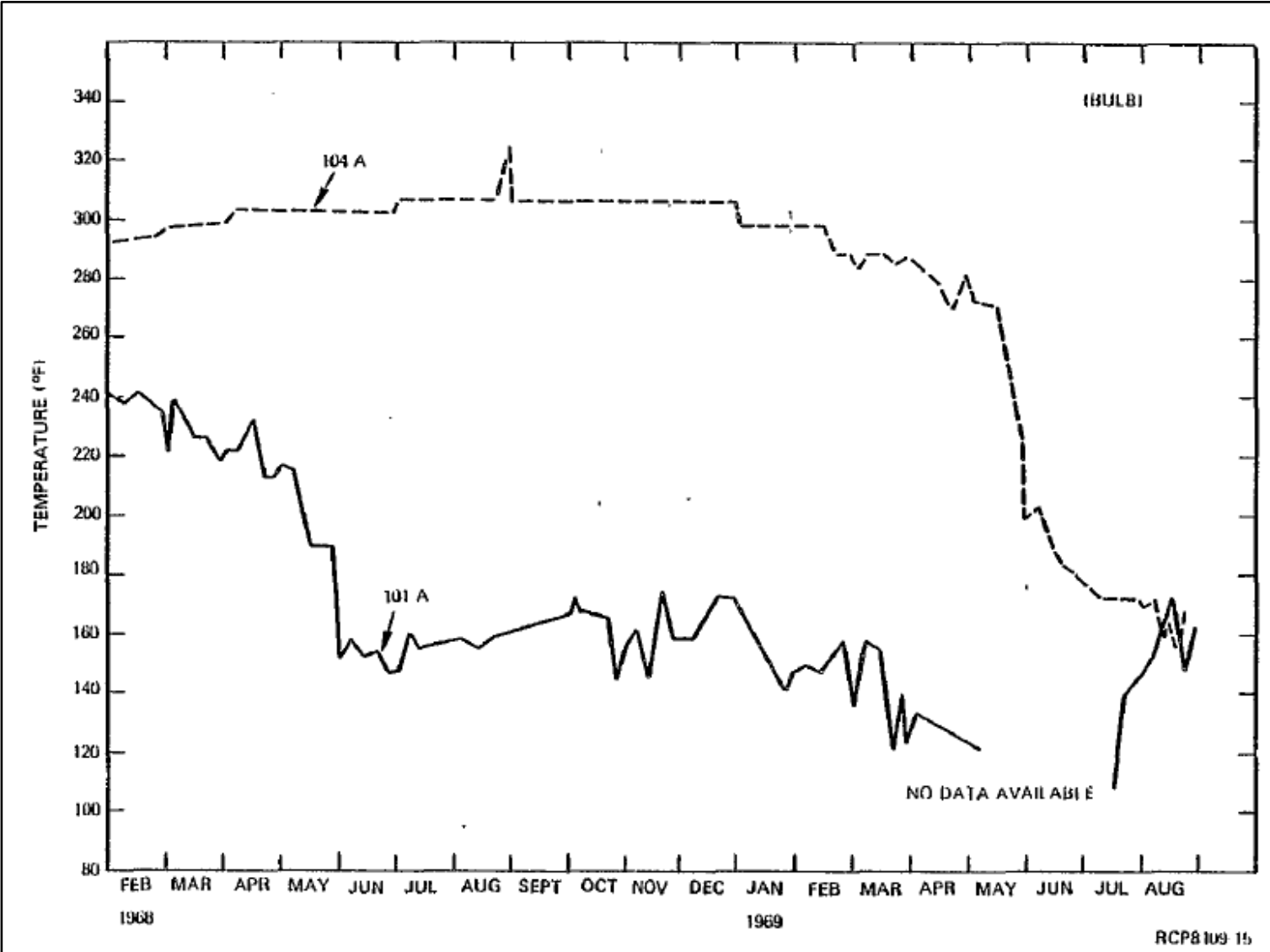

FIGURE B-13. 241-A-101 and -104 (Buib Temp.)

Feb. 1968 - Aug. 1969

Note: Bulb (sludge) temperature 2-in to 3-in off the tank bottom (see Section 3.2.2) 
RPP-RPT-54912, Rev. 0

Figure B1-6. RHO-CD-1172 Tank A-104 Temperature September 1969 through March 1970

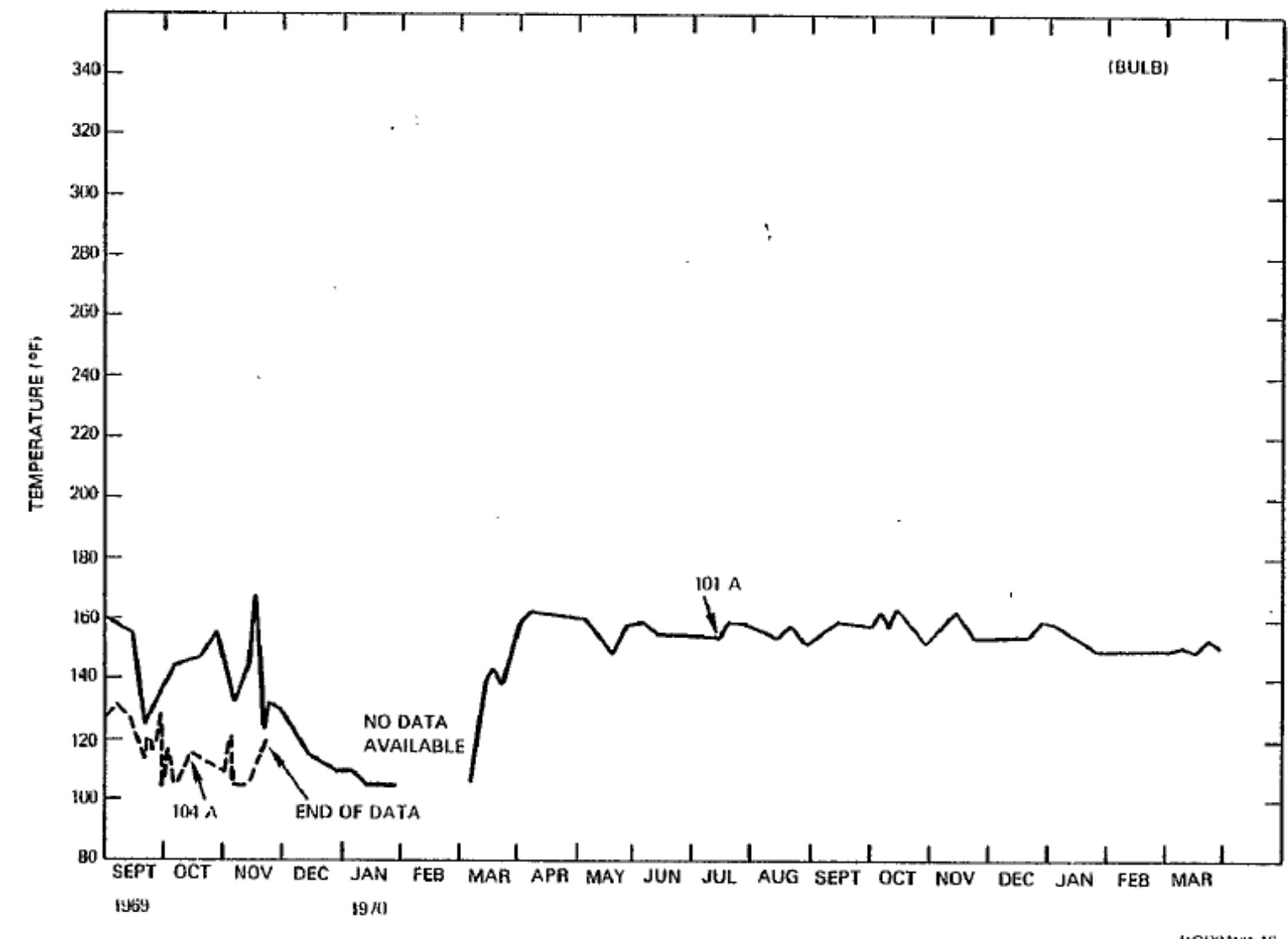

FIGURE B-14. 241-A-101 and -104 (Bulb Temp.)

Sept. 1969 thru Mar. 1970

Note: Bulb (sludge) temperature 2-in to 3-in off the tank bottom (see Section 3.2.2) 
RPP-RPT-54912, Rev. 0

\section{APPENDIX C1}

TANK A-104 LATERAL ACTIVITY

C1-1 
RPP-RPT-54912, Rev. 0

\section{Table C1-1. Tank 241-A-104 Lateral Radioactivity (K counts per minute) (July 1974 through June 1986) (Occurrence Report 75-39) (1 of 4 sheets)}

\begin{tabular}{|c|c|c|c|c|c|c|c|c|}
\hline \multicolumn{3}{|c|}{ 14-04-01 } & \multicolumn{3}{|c|}{ 14-04-02 } & \multicolumn{3}{|c|}{ 14-04-03 } \\
\hline Date & Peak (cpm) & Distance $(\mathrm{ft})^{3}$ & Date & Peak (cpm) & Distance $(\mathbf{f t})^{3}$ & Date & Peak (cpm) & Distance $(\mathbf{f t})^{3}$ \\
\hline $7 / 25 / 1974$ & $<25$ & $\mathrm{~N} / \mathrm{A}^{1}$ & $7 / 25 / 1974$ & $<25$ & N/A ${ }^{1}$ & $7 / 25 / 1974$ & $<25$ & $\mathrm{~N}^{\prime} \mathrm{A}^{1}$ \\
\hline 9/25/1974 & $<60$ & $\mathrm{~N} / \mathrm{A}^{1}$ & $9 / 25 / 1974$ & $<60$ & N/A ${ }^{1}$ & $9 / 28 / 1974$ & $<55$ & N/A ${ }^{1}$ \\
\hline $10 / 4 / 1974$ & $<90$ & N/A ${ }^{1}$ & $10 / 4 / 1974$ & $<90$ & $\mathrm{~N}^{\prime} \mathrm{A}^{1}$ & $10 / 4 / 1974$ & $<55$ & $\mathrm{~N} / \mathrm{A}^{1}$ \\
\hline $11 / 5 / 1974$ & $<50$ & $\mathrm{~N} / \mathrm{A}^{1}$ & $11 / 5 / 1974$ & $<90$ & N/A ${ }^{1}$ & $11 / 4 / 1974$ & $<50$ & $\mathrm{~N}^{\prime} \mathrm{A}^{1}$ \\
\hline $12 / 10 / 1974$ & $<30$ & $\mathrm{~N} / \mathrm{A}^{1}$ & $12 / 10 / 1974$ & $<30$ & $\mathrm{~N}^{\prime} \mathrm{A}^{1}$ & $12 / 10 / 1974$ & $<30$ & $\mathrm{~N}^{\prime} \mathrm{A}^{1}$ \\
\hline $12 / 31 / 1974$ & $<30$ & N/A ${ }^{1}$ & $12 / 31 / 1974$ & $<30$ & N/A ${ }^{1}$ & $12 / 31 / 1974$ & $<50$ & $\mathrm{~N}^{\prime} \mathrm{A}^{1}$ \\
\hline $1 / 7 / 1975$ & $<50$ & $\mathrm{~N} / \mathrm{A}^{1}$ & $1 / 7 / 1975$ & $<50$ & N/A ${ }^{1}$ & $1 / 7 / 1975$ & $<75$ & $\mathrm{~N}^{\prime} \mathrm{A}^{1}$ \\
\hline $1 / 16 / 1975$ & $<50$ & N/A ${ }^{1}$ & $1 / 16 / 1975$ & $<50$ & N/A ${ }^{1}$ & $1 / 16 / 1975$ & $<60$ & $\mathrm{~N}^{\prime} \mathrm{A}^{1}$ \\
\hline $1 / 20 / 1975$ & $<60$ & N/A ${ }^{1}$ & $1 / 20 / 1975$ & $<50$ & $\mathrm{~N}^{\prime} \mathrm{A}^{1}$ & $1 / 20 / 1975$ & $<55$ & $\mathrm{~N} / \mathrm{A}^{1}$ \\
\hline $1 / 30 / 1975$ & $<30$ & N/A ${ }^{1}$ & $1 / 30 / 1975$ & $<35$ & N/A ${ }^{1}$ & $1 / 30 / 1975$ & $<50$ & N/A ${ }^{1}$ \\
\hline $2 / 5 / 1975$ & $<30$ & N/A ${ }^{1}$ & $2 / 5 / 1975$ & $<35$ & $\mathrm{~N} / \mathrm{A}^{1}$ & $2 / 5 / 1975$ & $<50$ & N/A ${ }^{1}$ \\
\hline \multicolumn{3}{|c|}{$\mathrm{N} / \mathrm{A}^{1}$} & $2 / 11 / 1975$ & $<30$ & N/A ${ }^{1}$ & $2 / 11 / 1975$ & $<50$ & $\mathrm{~N} / \mathrm{A}^{1}$ \\
\hline \multicolumn{3}{|c|}{$\mathrm{N} / \mathrm{A}^{1}$} & $2 / 12 / 1975$ & $<50$ & $\mathrm{~N}^{\prime} \mathrm{A}^{1}$ & $2 / 12 / 1975$ & $<55$ & N/A ${ }^{1}$ \\
\hline $2 / 18 / 1975$ & $<55$ & $\mathrm{~N}^{\prime} \mathrm{A}^{1}$ & $2 / 18 / 1975$ & $<60$ & $\mathrm{~N}^{\prime} \mathrm{A}^{1}$ & $2 / 18 / 1975$ & $<50$ & $\mathrm{~N}^{\prime} \mathrm{A}^{1}$ \\
\hline \multicolumn{3}{|c|}{$\mathrm{N} / \mathrm{A}^{1}$} & $2 / 25 / 1975$ & $<50$ & N/A ${ }^{1}$ & $2 / 25 / 1975$ & $<50$ & $\mathrm{~N}^{\prime} \mathrm{A}^{1}$ \\
\hline $3 / 4 / 1975$ & $<55$ & $\mathrm{~N}^{\prime} \mathrm{A}^{1}$ & $3 / 4 / 1975$ & $<50$ & N/A ${ }^{1}$ & $3 / 4 / 1975$ & $<50$ & $\mathrm{~N}^{\prime} \mathrm{A}^{1}$ \\
\hline \multicolumn{3}{|c|}{$\mathrm{N}^{\prime} \mathrm{A}^{1}$} & $3 / 11 / 1975$ & $<60$ & N/A ${ }^{1}$ & $3 / 11 / 1975$ & $<50$ & $\mathrm{~N} / \mathrm{A}^{1}$ \\
\hline \multicolumn{3}{|c|}{ N/A ${ }^{1}$} & $3 / 18 / 1975$ & 100 & 93.6 & $3 / 18 / 1975$ & $<60$ & $\mathrm{~N} / \mathrm{A}^{1}$ \\
\hline $3 / 25 / 1975$ & $<65$ & $\mathrm{~N} / \mathrm{A}^{1}$ & $3 / 25 / 1975$ & 305 & 93.6 & $3 / 25 / 1975$ & $<60$ & $\mathrm{~N}^{\prime} \mathrm{A}^{1}$ \\
\hline \multirow{2}{*}{$4 / 8 / 1975$} & \multirow{2}{*}{105} & \multirow{2}{*}{38.6} & \multirow{2}{*}{ 4/8/1975 } & 220 & 67.6 & \multirow{2}{*}{ 4/8/1975 } & \multirow{2}{*}{$<50$} & \multirow{2}{*}{ N/A ${ }^{1}$} \\
\hline & & & & 700 & 95.6 & & & \\
\hline \multirow{2}{*}{$4 / 8 / 1975$} & \multirow{2}{*}{105} & \multirow{2}{*}{38.6} & \multirow{2}{*}{$4 / 8 / 1975$} & 200 & 67.6 & \multirow{2}{*}{$4 / 8 / 1975$} & \multirow{2}{*}{$<50$} & \multirow{2}{*}{$\mathrm{N} / \mathrm{A}^{1}$} \\
\hline & & & & 1170 & 95.6 & & & \\
\hline \multirow{2}{*}{$4 / 8 / 1975$} & \multirow{2}{*}{155} & \multirow{2}{*}{38.6} & \multirow{2}{*}{$4 / 8 / 1975$} & 495 & 67.6 & $4 / 8 / 1975$ & $<60$ & $N / A^{1}$ \\
\hline & & & & 1305 & 95.6 & & & \\
\hline & $\mathrm{N} / \mathrm{A}^{1}$ & & $4 / 8 / 1975$ & 420 & 67.6 & & $\mathrm{~N} / \mathrm{A}^{1}$ & \\
\hline & & & & 1860 & 95.6 & & & \\
\hline & $\mathrm{N} / \mathrm{A}^{1}$ & & 4/8/1975 & 390 & 67.6 & & $\mathrm{~N} / \mathrm{A}^{1}$ & \\
\hline & & & & 1665 & 95.6 & & & \\
\hline & $\mathrm{N} / \mathrm{A}^{1}$ & & $4 / 8 / 1975$ & 375 & 67.6 & & $\mathrm{~N} / \mathrm{A}^{1}$ & \\
\hline & & & & 1725 & 95.6 & & & \\
\hline $4 / 9 / 1975$ & 210 & 38.6 & 4/9/1975 & 600 & 67.6 & $4 / 9 / 1975$ & $<50$ & $\mathrm{~N} / \mathrm{A}^{1}$ \\
\hline & & & & 1965 & 95.6 & & & \\
\hline & $\mathrm{N} / \mathrm{A}^{1}$ & & $4 / 9 / 1975$ & 855 & 67.6 & $4 / 9 / 1975$ & $<50$ & $\mathrm{~N} / \mathrm{A}^{1}$ \\
\hline & & & & 1980 & 95.6 & & & \\
\hline
\end{tabular}


RPP-RPT-54912, Rev. 0

Table C1-1. Tank 241-A-104 Lateral Radioactivity (K counts per minute) (July 1974 through June 1986)

(Occurrence Report 75-39) ( 2 of 4 sheets)

\begin{tabular}{|c|c|c|c|c|c|c|c|c|}
\hline \multicolumn{3}{|c|}{ 14-04-01 } & \multicolumn{3}{|c|}{ 14-04-02 } & \multicolumn{3}{|c|}{ 14-04-03 } \\
\hline Date & Peak (cpm) & Distance $(\mathrm{ft})^{3}$ & Date & Peak (cpm) & $\begin{array}{c}\begin{array}{c}\text { Distance } \\
(\mathbf{f t})^{3}\end{array} \\
\end{array}$ & Date & Peak (cpm) & Distance $(\mathbf{f t})^{3}$ \\
\hline \multirow{2}{*}{\multicolumn{3}{|c|}{ N/A ${ }^{1}$}} & \multirow{2}{*}{ 4/9/1975 } & 615 & 67.6 & \multirow{2}{*}{\multicolumn{3}{|c|}{ N/A ${ }^{1}$}} \\
\hline & & & & 2055 & 95.6 & & & \\
\hline \multirow{2}{*}{$4 / 10 / 1975$} & \multirow{2}{*}{205} & \multirow{2}{*}{38.6} & \multirow{2}{*}{$4 / 10 / 1975$} & 800 & 67.6 & \multirow{2}{*}{$4 / 10 / 1975$} & \multirow{2}{*}{$<50$} & \multirow{2}{*}{$\mathrm{N} / \mathrm{A}^{1}$} \\
\hline & & & & 2850 & 95.6 & & & \\
\hline \multirow{2}{*}{$4 / 11 / 1975$} & \multirow{2}{*}{185} & \multirow{2}{*}{38.6} & \multirow{2}{*}{$4 / 11 / 1975$} & 750 & 67.6 & \multirow{2}{*}{\multicolumn{3}{|c|}{ N/A ${ }^{1}$}} \\
\hline & & & & 3100 & 95.6 & & & \\
\hline \multirow{2}{*}{$4 / 12 / 1975$} & \multirow{2}{*}{205} & \multirow{2}{*}{38.6} & \multirow{2}{*}{$4 / 12 / 1975$} & 850 & 67.6 & \multirow{2}{*}{\multicolumn{3}{|c|}{ N/A ${ }^{1}$}} \\
\hline & & & & 3200 & 95.6 & & & \\
\hline \multirow{2}{*}{ 4/13/1975 } & \multirow{2}{*}{245} & 386 & $4 / 13 / 1975$ & 1050 & 67.6 & & $\mathrm{~N} / \mathrm{A}^{1}$ & \\
\hline & & & & 2850 & 95.6 & & & \\
\hline $4 / 14 / 1975$ & 345 & 38.6 & $4 / 14 / 1975$ & 1000 & 67.6 & & N/A ${ }^{1}$ & \\
\hline & & & & 3200 & 95.6 & & & \\
\hline $4 / 15 / 1975$ & 420 & 386 & $4 / 15 / 1975$ & 950 & 67.6 & & $N / A^{1}$ & \\
\hline & & & & 3350 & 95.6 & & & \\
\hline & $\mathrm{N} / \mathrm{A}^{1}$ & & $4 / 16 / 1975$ & 1150 & 67.6 & & $\mathrm{~N} / \mathrm{A}^{1}$ & \\
\hline & & & & 3800 & 95.6 & & & \\
\hline $4 / 17 / 1975$ & 465 & 386 & $4 / 17 / 1975$ & 900 & 67.6 & & $N / A^{1}$ & \\
\hline $4 / 17 / 197 / 5$ & $40 J$ & 30.0 & $4 / 171815$ & 3750 & 95.6 & & & \\
\hline & $\mathrm{N} / \mathrm{A}^{1}$ & & $4 / 18 / 1975$ & 1100 & 67.6 & & $\mathrm{~N} / \mathrm{A}^{1}$ & \\
\hline & & & & 4150 & 95.6 & & & \\
\hline $4 / 19 / 1975$ & 445 & 386 & $4 / 19 / 1975$ & 750 & 67.6 & & N/A ${ }^{1}$ & \\
\hline & & & & 3750 & 95.6 & & & \\
\hline $4 / 20 / 1975$ & 475 & 386 & $4 / 20 / 1975$ & 1100 & 67.6 & $4 / 20 / 1975$ & $<50$ & $N / A^{1}$ \\
\hline & & & & 4850 & 95.6 & & & \\
\hline $4 / 21 / 1975$ & 680 & 38.6 & & N/A ${ }^{1}$ & & $4 / 21 / 1975$ & 95 & 96 \\
\hline 122/1075 & 1705 & 286 & 19211075 & 700 & 67.6 & 1/2075 & 205 & 06 \\
\hline $4 / 2271975$ & $1 / 0 J$ & 30.0 & $4 / 22 / 1915$ & 4350 & 95.6 & 4/2211915 & 205 & 90 \\
\hline & $\mathrm{N} / \mathrm{A}^{1}$ & & $4 / 23 / 1975$ & 1100 & 67.6 & & $\mathrm{~N} / \mathrm{A}^{1}$ & \\
\hline & & & & 3900 & 95.6 & & & \\
\hline & $\mathrm{N} / \mathrm{A}^{1}$ & & $4 / 24 / 1975$ & 900 & 67.6 & $4 / 24 / 1975$ & 390 & 96 \\
\hline & & & & 5250 & 95.6 & & & \\
\hline & N/A ${ }^{1}$ & & $4 / 25 / 1975$ & 1150 & 67.6 & & $\mathrm{~N} / \mathrm{A}^{1}$ & \\
\hline & & & & 4450 & 95.6 & & & \\
\hline $4 / 26 / 1975$ & 1665 & 386 & $4 / 26 / 1975$ & 900 & 67.6 & $4 / 26 / 1975$ & 400 & 96 \\
\hline & & & & 4000 & 95.6 & & & \\
\hline $4 / 27 / 1975$ & 3400 & 38.6 & $4 / 27 / 1975$ & 1750 & 67.6 & & $\mathrm{~N} / \mathrm{A}^{1}$ & \\
\hline & & & & 4750 & 95.6 & & & \\
\hline
\end{tabular}

C1-3 
RPP-RPT-54912, Rev. 0

Table C1-1. Tank 241-A-104 Lateral Radioactivity ( $K$ counts per minute) (July 1974 through June 1986)

(Occurrence Report 75-39) (3 of 4 sheets)

\begin{tabular}{|c|c|c|c|c|c|c|c|c|}
\hline \multicolumn{3}{|c|}{ 14-04-01 } & \multicolumn{3}{|c|}{ 14-04-02 } & \multicolumn{3}{|c|}{ 14-04-03 } \\
\hline Date & Peak (cpm) & Distance $(\mathrm{ft})^{3}$ & Date & Peak (cpm) & Distance (ft) ${ }^{3}$ & Date & Peak (cpm) & Distance $(\mathrm{ft})^{3}$ \\
\hline \multirow{2}{*}{$4 / 28 / 1975$} & \multirow{2}{*}{3650} & \multirow{2}{*}{38.6} & \multirow{2}{*}{$4 / 28 / 1975$} & 1050 & 67.6 & \multirow{2}{*}{$4 / 28 / 1975$} & \multirow{2}{*}{320} & \multirow{2}{*}{96} \\
\hline & & & & 5000 & 95.6 & & & \\
\hline $4 / 29 / 1975$ & 2450 & 38.6 & \multicolumn{3}{|c|}{$\mathrm{N} / \mathrm{A}^{1}$} & \multicolumn{3}{|c|}{$\mathrm{N}^{\prime} \mathrm{A}^{1}$} \\
\hline \multirow{2}{*}{$5 / 1 / 1975$} & \multirow{2}{*}{2745} & \multirow{2}{*}{38.6} & \multirow{2}{*}{$5 / 1 / 1975$} & 1200 & 47 & \multirow{2}{*}{\multicolumn{3}{|c|}{$\mathrm{N} / \mathrm{A}^{1}$}} \\
\hline & & & & 4900 & 93 & & & \\
\hline $5 / 2 / 1975$ & 4350 & 38.6 & \multicolumn{3}{|c|}{ N/A ${ }^{1}$} & $5 / 2 / 1975$ & 480 & 96 \\
\hline $5 / 5 / 1975$ & 4520 & 38.6 & \multicolumn{3}{|c|}{$\mathrm{N} / \mathrm{A}^{1}$} & \multicolumn{3}{|c|}{$\mathrm{N}^{\prime} \mathrm{A}^{1}$} \\
\hline \multirow{2}{*}{$5 / 7 / 1975$} & \multirow{2}{*}{4450} & \multirow{2}{*}{38.6} & \multirow{2}{*}{$5 / 7 / 1975$} & 1150 & 67.6 & \multirow{2}{*}{$5 / 7 / 1975$} & \multirow{2}{*}{325} & 06 \\
\hline & & & & 4550 & 95.6 & & & 30 \\
\hline $5 / 19 / 1975$ & 650 & 45 & & $N / A^{1}$ & & $5 / 16 / 1975$ & 365 & 96 \\
\hline & 5800 & 35 & & & & 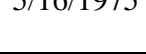 & 305 & 90 \\
\hline & N/A ${ }^{1}$ & & & $\mathrm{~N} / \mathrm{A}^{1}$ & & $6 / 6 / 1975$ & 280 & 96 \\
\hline $6 / 0 / 1075$ & 1350 & 45 & $6 / 0 / 1075$ & 1000 & 47 & $6 / 0 / 1075$ & 275 & 06 \\
\hline & 6450 & 35 & & 5300 & 93 & & & \\
\hline & N/A ${ }^{1}$ & & & N/A ${ }^{1}$ & & $6 / 16 / 1975$ & 235 & 98 \\
\hline & N/A ${ }^{1}$ & & & $\mathrm{~N}^{\prime} \mathrm{A}^{1}$ & & $6 / 23 / 1975$ & 385 & 98 \\
\hline & N/A ${ }^{1}$ & & & $\mathrm{~N} / \mathrm{A}^{1}$ & & $6 / 30 / 1975$ & 365 & 98 \\
\hline & $N / A^{1}$ & & $10 / 6 / 1975$ & 997 & 48 & $10 / 6 / 1975$ & 258 & 93 \\
\hline & & & & 7550 & 97 & & & \\
\hline & 325 & 53 & & 720 & 48 & & & \\
\hline 1/7/1976 & 450 & 46 & 1/6/1976 & 5850 & 97 & $1 / 6 / 1976$ & 330 & 93 \\
\hline & 3380 & 34 & & & & & & \\
\hline & & & & 600 & 48 & & & \\
\hline & $\mathrm{N} / \mathrm{A}^{1}$ & & $2 / 24 / 1976$ & 300 & 84 & & $\mathrm{~N} / \mathrm{A}^{1}$ & \\
\hline & & & & 5600 & 97 & & & \\
\hline & 700 & 55 & & 1000 & 48 & & & \\
\hline 4/6/1976 & 500 & 47 & 4/6/1976 & 300 & 84 & 4/6/1976 & 220 & 93 \\
\hline & 2100 & 35 & & 5680 & 97 & & & \\
\hline & N/A ${ }^{1}$ & & $6 / 2 / 1976$ & 5400 & 97 & & N/A ${ }^{1}$ & \\
\hline & & & & 600 & 48 & & & \\
\hline & 750 & 38 & & 750 & 48 & & & \\
\hline 7/12/1976 & 640 & 74 & $7 / 12 / 1976$ & 640 & 84 & $7 / 12 / 1976$ & 273 & 94 \\
\hline & 5580 & 87 & & 5580 & 97 & & & \\
\hline & 1100 & 55 & & & & & & \\
\hline $10 / 4 / 1976$ & 650 & 48 & & $\mathrm{~N} / \mathrm{A}^{1}$ & & $11 / 5 / 1976$ & 180 & 93 \\
\hline & 1100 & 37 & & & & & & \\
\hline
\end{tabular}


RPP-RPT-54912, Rev. 0

Table C1-1. Tank 241-A-104 Lateral Radioactivity (K counts per minute) (July 1974 through June 1986)

(Occurrence Report 75-39) (4 of 4 sheets)

\begin{tabular}{|c|c|c|c|c|c|c|c|c|}
\hline \multicolumn{3}{|c|}{ 14-04-01 } & \multicolumn{3}{|c|}{ 14-04-02 } & \multicolumn{3}{|c|}{ 14-04-03 } \\
\hline Date & Peak (cpm) & $\begin{array}{c}\text { Distance } \\
(\mathbf{f t})^{3}\end{array}$ & Date & Peak (cpm) & $\begin{array}{c}\text { Distance } \\
(\mathbf{f t})^{3}\end{array}$ & Date & Peak (cpm) & Distance $(\mathbf{f t})^{3}$ \\
\hline \multirow{3}{*}{$3 / 3 / 1977$} & 1260 & 55 & \multirow{3}{*}{$3 / 3 / 1977$} & 2310 & 97 & \multirow{3}{*}{$3 / 1 / 1977$} & \multirow{3}{*}{178} & \multirow{3}{*}{93} \\
\hline & 575 & 48 & & 400 & 48 & & & \\
\hline & 780 & 37 & & & & & & \\
\hline \multirow{3}{*}{$4 / 1 / 1977^{2}$} & 120 & 58.6 & \multirow{3}{*}{$3 / 22 / 1977^{2}$} & 15000 & 125.5 & \multirow{3}{*}{$3 / 22 / 1977^{2}$} & 60 & 76.6 \\
\hline & 74 & 51.6 & & 3600 & 115.5 & & 17 & 21.6 \\
\hline & 57 & 40.6 & & 2400 & 71.5 & & & \\
\hline \multirow{3}{*}{$11 / 1 / 1977$} & 88 & 59.6 & \multirow{3}{*}{\multicolumn{3}{|c|}{$\mathrm{N} / \mathrm{A}^{1}$}} & \multirow{3}{*}{\multicolumn{3}{|c|}{ N/A ${ }^{1}$}} \\
\hline & 67 & 53.6 & & & & & & \\
\hline & 28 & 42.6 & & & & & & \\
\hline \multirow{3}{*}{\multicolumn{3}{|c|}{$\mathrm{N} / \mathrm{A}^{1}$}} & \multirow{3}{*}{$2 / 10 / 1978$} & 8100 & 125.5 & \multirow{3}{*}{$1 / 4 / 1978$} & 56 & 76.6 \\
\hline & & & & 5280 & 115.5 & & 7.7 & 18.6 \\
\hline & & & & 2400 & 71.5 & & & \\
\hline \multirow{3}{*}{$6 / 8 / 1978$} & 80 & 59.6 & \multirow{3}{*}{\multicolumn{3}{|c|}{$\mathrm{N} / \mathrm{A}^{1}$}} & \multirow{3}{*}{\multicolumn{3}{|c|}{$\mathrm{N} / \mathrm{A}^{1}$}} \\
\hline & 54 & 53.6 & & & & & & \\
\hline & 28 & 38.6 & & & & & & \\
\hline \multirow{3}{*}{$12 / 5 / 1978$} & 53 & 60.6 & \multirow{3}{*}{$12 / 5 / 1978$} & 2580 & 125.5 & \multirow{3}{*}{$12 / 5 / 1978$} & 36 & 76.6 \\
\hline & 36 & 54.6 & & 2400 & 115.5 & & 23 & 75.6 \\
\hline & 16 & 39.6 & & 720 & 71.5 & & 10.8 & 18.6 \\
\hline \multirow{3}{*}{ 10/10/1979 } & 30 & 59.6 & \multirow{3}{*}{$10 / 10 / 1979$} & 2160 & 126.5 & \multirow{3}{*}{\multicolumn{3}{|c|}{ N/A ${ }^{1}$}} \\
\hline & 31 & 55.6 & & 2760 & 115.5 & & & \\
\hline & 14 & 40.6 & & 900 & 78.5 & & & \\
\hline $10 / 16 / 1980$ & 12 & 49.6 & $10 / 16 / 1980$ & 1320 & 121.5 & $10 / 16 / 1980$ & 22 & 90.6 \\
\hline 10/23/1981 & 11 & 54.6 & $10 / 23 / 1981$ & 1320 & 122.5 & $10 / 23 / 1981$ & 12 & 90.6 \\
\hline \multicolumn{3}{|c|}{$\mathrm{N}^{\prime} \mathrm{A}^{1}$} & \multicolumn{3}{|c|}{$\mathrm{N}^{\prime} \mathrm{A}^{1}$} & $1 / 13 / 1982$ & 9 & 89.6 \\
\hline $12 / 15 / 1982$ & $<10$ & $\mathrm{~N} / \mathrm{A}^{1}$ & $12 / 15 / 1982$ & 960 & 124.5 & $12 / 15 / 1982$ & $<10$ & $\mathrm{~N}^{\prime} \mathrm{A}^{1}$ \\
\hline $8 / 26 / 1983$ & $<10$ & N/A ${ }^{1}$ & $8 / 26 / 1983$ & 960 & 122.5 & $8 / 26 / 1983$ & $<10$ & $\mathrm{~N}^{\prime} \mathrm{A}^{1}$ \\
\hline $9 / 15 / 1983$ & $<10$ & N/A ${ }^{1}$ & $9 / 15 / 1983$ & 780 & 124.5 & & $\mathrm{~N}^{\prime} \mathrm{A}^{1}$ & \\
\hline $11 / 18 / 1983$ & $<10$ & $\mathrm{~N} / \mathrm{A}^{1}$ & $11 / 18 / 1983$ & 840 & 124.5 & & $\mathrm{~N}^{\prime} \mathrm{A}^{1}$ & \\
\hline $10 / 15 / 1984$ & $<10$ & $\mathrm{~N}^{\prime} \mathrm{A}^{1}$ & $10 / 15 / 1984$ & 840 & 127.5 & & $\mathrm{~N}^{\prime} \mathrm{A}^{1}$ & \\
\hline 9/16/1985 & $<10$ & $\mathrm{~N}^{\prime} \mathrm{A}^{1}$ & $9 / 16 / 1985$ & 720 & 126.5 & & $\mathrm{~N}^{\prime} \mathrm{A}^{1}$ & \\
\hline $6 / 20 / 1986$ & $<10$ & $\mathrm{~N}^{\prime} \mathrm{A}^{1}$ & $6 / 20 / 1986$ & 660 & 125.5 & & N/A ${ }^{1}$ & \\
\hline
\end{tabular}


RPP-RPT-54912, Rev. 0

\section{APPENDIX D1}

TANK A-104 GROSS GAMMA DRYWELL DATA

D1-1 
Table D1-1. Tank 241-A-104 Drywell Radioactivity (K counts per minute) (January 1965 to November 1986)

(Drywell Data Sheets Retrieved on December 6, 2012 and SD-WM-TI-356) (1 of 2 sheets)

\begin{tabular}{|c|c|c|c|c|c|c|c|c|c|c|c|c|c|c|c|c|c|c|c|c|c|c|c|}
\hline \multicolumn{3}{|c|}{ 10-04-01 } & \multicolumn{2}{|c|}{$10-04-04$} & \multicolumn{4}{|c|}{$10-04-05$} & \multicolumn{3}{|c|}{$10-04-07$} & \multicolumn{3}{|c|}{$10-04-08$} & \multicolumn{3}{|c|}{$10-04-10$} & \multicolumn{3}{|c|}{$10-04-12$} & \multicolumn{3}{|c|}{$10-05-09$} \\
\hline Date & $\begin{array}{c}\text { Peak } \\
(\text { K cpm })\end{array}$ & $\begin{array}{c}\text { Depth } \\
\text { (ft) }\end{array}$ & Date & $\begin{array}{c}\text { Peak } \\
\text { (K cpm) }\end{array}$ & \begin{tabular}{|c|c|} 
Depth \\
(ft)
\end{tabular} & Date & $\begin{array}{c}\text { Peak } \\
\text { (K cpm) }\end{array}$ & $\begin{array}{c}\text { Depth } \\
\text { (ft) }\end{array}$ & Date & $\begin{array}{c}\text { Peak (K } \\
\text { cpm) }\end{array}$ & $\begin{array}{c}\text { Depth } \\
\text { (ft) }\end{array}$ & Date & $\begin{array}{c}\text { Peak } \\
\text { (K cpm) }\end{array}$ & $\begin{array}{c}\text { Depth } \\
\text { (ft) }\end{array}$ & Date & $\begin{array}{c}\text { Peak } \\
\text { (K cpm) }\end{array}$ & $\begin{array}{c}\text { Depth } \\
\text { (ft) }\end{array}$ & Date & $\begin{array}{c}\text { Peak } \\
\text { (K cpm) }\end{array}$ & $\begin{array}{c}\text { Depth } \\
\text { (ft) }\end{array}$ & Date & $\begin{array}{c}\text { Peak } \\
\text { (K cpm) }\end{array}$ & $\begin{array}{c}\text { Depth } \\
\text { (ft) }\end{array}$ \\
\hline \multirow{4}{*}{$1 / 7 / 1965$} & 7 & 50 & \multirow{4}{*}{\multicolumn{3}{|c|}{$\mathrm{N} / \mathrm{A}^{1}$}} & \multirow{4}{*}{$1 / 7 / 1965$} & 7 & 50 & \multirow{4}{*}{\multicolumn{3}{|c|}{ (pin) I (it) }} & \multirow{4}{*}{\multicolumn{3}{|c|}{$\mathrm{N} / \mathrm{A}^{1}$}} & \multirow{4}{*}{\multicolumn{3}{|c|}{$N / A^{1}$}} & \multirow{4}{*}{ 1/3/1965 } & 600 & 6 & & 15 & 15 \\
\hline & 6 & 70 & & & & & 8 & 70 & & & & & & & & & & & 7 & 50 & $1 / 7 / 65$ & 6 & 50 \\
\hline & 15 & 75 & & & & & 18 & 75 & & & & & & & & & & & 12 & 75 & 1/7/65 & 6 & 70 \\
\hline & & & & & & & & & & & & & & & & & & & & & & 7 & 73 \\
\hline & 5 & 60 & & & & & 6 & 70 & & 5 & 50 & & 6 & 60 & & 6 & 50 & & 500 & 6 & & 6 & 16 \\
\hline $11 / 3 / 1965$ & & & & $N / A^{1}$ & & $11 / 3 / 1965$ & & & 10/28/1965 & 5 & 73 & $11 / 3 / 1965$ & & & $11 / 3 / 1965$ & & & $11 / 3 / 1965$ & 6 & $\begin{array}{l}60 \\
75 \\
75\end{array}$ & $11 / 3 / 65$ & $\frac{25}{5}$ & 19 \\
\hline & 9 & 75 & & & & & 15 & 75 & & & & & 8 & 75 & & 8 & 75 & & 10 & 75 & & $\frac{5}{9}$ & 74 \\
\hline & $N / A^{1}$ & & & $\mathrm{~N} / \mathrm{A}^{1}$ & & & $N / A^{1}$ & & & $\mathrm{~N} / \mathrm{A}^{1}$ & & & $N / A^{1}$ & & & $N / A^{1}$ & & $11 / 12 / 1965$ & $\frac{160}{5}$ & $\frac{6}{50}$ & & $N / A^{1}$ & \\
\hline & & & & & & & & & & & & & & & & & & & 12 & 73 & & & \\
\hline & $N / A^{1}$ & & & $N / A^{1}$ & & & $N / A^{1}$ & & & $N / A^{1}$ & & & $N / A^{1}$ & & & $N / A^{1}$ & & $11 / 18 / 1965$ & $\begin{array}{c}380 \\
6\end{array}$ & 6 & & $N / A^{1}$ & \\
\hline & & & & & & & & & & & & & & & & & & & 11 & 75 & & & \\
\hline & 5.8 & 25 & & & & & 6 & 25 & & 5 & 25 & & 5.7 & 25 & & 5 & 25 & & 500 & 6 & & 6 & 25 \\
\hline & 5.5 & 50 & & & & & 8 & 50 & & 5.2 & 50 & & 4.4 & 50 & & 5.4 & 50 & & 6.2 & 25 & & 7 & 50 \\
\hline $11 / 22 / 1965$ & 7 & 73 & & $N / A^{1}$ & & 11/22/1965 & 5 & 70 & 11/22/1965 & 5.9 & 70 & 11/22/1965 & 5.5 & 70 & $11 / 22 / 1965$ & 5.8 & 70 & 11/22/1965 & 5 & 50 & $11 / 22 / 65$ & 5 & 70 \\
\hline & 11 & 75 & & & & & 18 & 75 & & 9.8 & 75 & & 8.5 & 75 & & 8.2 & 75 & & 7.8 & 74 & & & \\
\hline & & & & & & & & & & & & & & & & & & & 11 & 76 & & & \\
\hline & & & & & & & & & & 7 & 50 & & 7 & 50 & & 7 & 50 & & 450 & 6 & & 15 & 15 \\
\hline & $N / A^{1}$ & & & $N / A^{1}$ & & & $\mathrm{~N} / \mathrm{A}^{1}$ & & $1 / 7 / 1966$ & 12 & 58 & $1 / 7 / 1966$ & 7 & 70 & $1 / 7 / 1966$ & 6 & 70 & & 8 & 50 & & 6 & 50 \\
\hline & & & & & & & & & $1 / / 1 / 1966$ & 7 & 70 & 1/7/1966 & 8 & 74 & 1/7/1966 & 11 & 74 & 1/21/1966 & 10 & 70 & 1/27/66 & 6 & 70 \\
\hline & & & & & & & & & & 8 & 75 & & & & & & & & 15 & 75 & & 7 & 73 \\
\hline & (1) & & & $N / 1$ & & & Wh & & & Not & & & ret & & & (1) & & & Nout & & 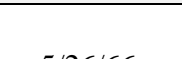 & 8 & \\
\hline & N/A & & & N/A $/ A^{2}$ & & & N/A & & & $\mathrm{N} / \mathrm{A}^{\mathrm{T}}$ & & & N/A & & & N/A & & & $\mathrm{N} / \mathrm{A}^{\mathrm{*}}$ & & 5/26/66 & $\frac{8}{60}$ & $\frac{70}{75}$ \\
\hline & & & & & & & & & & & & & & & & & & & & & & 8 & 50 \\
\hline & $\mathrm{N} / \mathrm{A}^{1}$ & & & $N / A^{1}$ & & & $\mathrm{~N} / \mathrm{A}^{1}$ & & & $\mathrm{~N} / \mathrm{A}^{1}$ & & & $\mathrm{~N} / \mathrm{A}^{1}$ & & & $\mathrm{~N} / \mathrm{A}^{1}$ & & & $N / A^{1}$ & & $8 / 26 / 66$ & 8 & 70 \\
\hline & & & 01121072 & & & & & & & & & & & & & & & & & & & 15 & 74 \\
\hline $\begin{array}{l}9 / 13 / 1972 \\
21 / 1973\end{array}$ & $<6$ & $\frac{N / A^{A}}{N / I^{1}}$ & $\begin{array}{r}9 / 13 / 1972 \\
21 / 1073\end{array}$ & $\begin{array}{l}<6 \\
6\end{array}$ & $\frac{N / A^{1}}{N}$ & $\begin{array}{r}9 / 13 / 1972 \\
2 / 1073 \\
\end{array}$ & $\begin{array}{l}<6 \\
6\end{array}$ & $N / A^{1}$ & $\begin{array}{l}9 / 13 / 1972 \\
2 / 1073 \\
\end{array}$ & $\frac{12}{66}$ & N/A & $\begin{array}{r}9 / 13 / 1972 \\
21 / 1072 \\
\end{array}$ & $<12$ & N/A & $9 / 13 / 1972$ & $<12$ & $\frac{N / A^{A}}{N / I^{1}}$ & $\begin{array}{r}9 / 13 / 1972 \\
2 / 1072\end{array}$ & $<12$ & $\frac{N / A^{1}}{N}$ & $9 / 13 / 72$ & $<6$ & $\mathrm{~N} / \mathrm{A}^{1}$ \\
\hline 4/9/1973 & $<6$ & $N / A^{1}$ & 4/19/1973 & $<6$ & \begin{tabular}{|l|l|}
$N / A^{1}$ \\
\end{tabular} & $4 / 9 / 1973$ & $<6$ & $\mathrm{~N} / \mathrm{A}^{1}$ & $4 / 4 / 1973$ & $\begin{array}{l}0 \\
<6\end{array}$ & $\mathrm{~N} / \mathrm{A}^{1}$ & $4 / 4 / 1973$ & $\begin{array}{l}<6 \\
<6\end{array}$ & $\mathrm{~N} / \mathrm{A}^{1}$ & $4 / 4 / 1973$ & $<6$ & $N / A^{1}$ & $4 / 9 / 1973$ & $\begin{array}{l}<6 \\
<6\end{array}$ & $\frac{N / A}{N / A^{1}}$ & $\begin{array}{r}2 / 1 / 73 \\
49 / 1973\end{array}$ & $<6$ & $\frac{N / A^{1}}{N A^{1}}$ \\
\hline $6 / 26 / 1973$ & $<6$ & $\mathrm{~N} / \mathrm{A}^{1}$ & $6 / 26 / 1973$ & $<6$ & $\mathrm{~N} / \mathrm{A}^{1}$ & $6 / 26 / 1973$ & $<6$ & $\mathrm{~N} / \mathrm{A}^{1}$ & $6 / 26 / 1973$ & $<6$ & $\mathrm{~N} / \mathrm{A}^{1}$ & $6 / 26 / 1973$ & $<6$ & $\mathrm{~N} / \mathrm{A}^{1}$ & 6/27/1973 & $<6$ & $\mathrm{~N} / \mathrm{A}^{1}$ & $6 / 26 / 1973$ & $<6$ & $\mathrm{~N} / \mathrm{A}^{1}$ & $6 / 26 / 73$ & $<6$ & $\mathrm{~N} / \mathrm{A}^{1}$ \\
\hline $7 / 5 / 1973$ & $<6$ & $\mathrm{~N} / \mathrm{A}^{1}$ & $7 / 5 / 1973$ & $<6$ & $\mathrm{~N} / \mathrm{A}^{1}$ & $7 / 5 / 1973$ & $<6$ & $\mathrm{~N} / \mathrm{A}^{1}$ & $7 / 5 / 1973$ & $<6$ & $\mathrm{~N} / \mathrm{A}^{1}$ & $7 / 5 / 1973$ & $<6$ & $\mathrm{~N} / \mathrm{A}^{1}$ & $7 / 5 / 1973$ & $<6$ & $\mathrm{~N} / \mathrm{A}^{1}$ & $7 / 5 / 1973$ & $<6$ & $\mathrm{~N} / \mathrm{A}^{1}$ & $7 / 5 / 73$ & $<6$ & $\mathrm{~N} / \mathrm{A}^{1}$ \\
\hline $8 / 10 / 1973$ & $<6$ & $\mathrm{~N} / \mathrm{A}^{1}$ & & $N / A^{1}$ & & $8 / 10 / 1973$ & $<6$ & $\mathrm{~N} / \mathrm{A}^{1}$ & $8 / 10 / 1973$ & $<6$ & $\mathrm{~N} / \mathrm{A}^{1}$ & $8 / 10 / 1973$ & $<6$ & $\mathrm{~N} / \mathrm{A}^{1}$ & $8 / 10 / 1973$ & $<6$ & $\mathrm{~N} / \mathrm{A}^{1}$ & $8 / 10 / 1973$ & $<6$ & $\mathrm{~N} / \mathrm{A}^{1}$ & $8 / 10 / 73$ & $<6$ & $N / A^{1}$ \\
\hline 9/6/1973 & $<6$ & $\mathrm{~N} / \mathrm{A}^{1}$ & 9/6/1973 & $<6$ & $\mathrm{~N} / \mathrm{A}^{1}$ & 9/6/1973 & $<6$ & $\mathrm{~N} / \mathrm{A}^{1}$ & 9/6/1973 & $<6$ & $\mathrm{~N} / \mathrm{A}^{1}$ & 9/6/1973 & $<6$ & $\mathrm{~N} / \mathrm{A}^{1}$ & 9/6/1973 & $<6$ & $\mathrm{~N} / \mathrm{A}^{1}$ & 9/6/1973 & $<6$ & $\mathrm{~N} / \mathrm{A}^{1}$ & 9/6/73 & $<6$ & $\mathrm{~N} / \mathrm{A}^{1}$ \\
\hline $10 / 4 / 1973$ & 6.1 & 12 & 10/4/1973 & $<6$ & $\mathrm{~N} / \mathrm{A}^{1}$ & $10 / 4 / 1973$ & 6.8 & 20 & $10 / 4 / 1973$ & $<6$ & $\mathrm{~N} / \mathrm{A}^{1}$ & 10/4/1973 & 6.1 & 20 & $10 / 4 / 1973$ & 6.5 & 11 & 10/4/1973 & 6.2 & 12 & $10 / 4 / 1973$ & 6.2 & 36 \\
\hline $11 / 8 / 1973$ & 9.5 & 17 & $11 / 9 / 1973$ & $<6$ & $\mathrm{~N} / \mathrm{A}^{1}$ & 11/9/1973 & 9.7 & 18 & 11/8/1973 & 9.5 & 17 & $11 / 8 / 1973$ & 9.1 & 18 & $11 / 8 / 1973$ & 9.6 & 11 & $11 / 8 / 1973$ & 9.2 & 18 & 11/9/1973 & 8.5 & 17 \\
\hline $2 / 1 / 1974$ & $<6$ & $\mathrm{~N} / \mathrm{A}^{1}$ & $1 / 5 / 1974$ & $<6$ & $\mathrm{~N} / \mathrm{A}^{1}$ & $2 / 7 / 1974$ & $<6$ & $\mathrm{~N} / \mathrm{A}^{1}$ & $2 / 7 / 1974$ & $<6$ & $\mathrm{~N} / \mathrm{A}^{1}$ & $2 / 7 / 1974$ & $<6$ & $\mathrm{~N} / \mathrm{A}^{1}$ & $2 / 7 / 1974$ & $<6$ & $\mathrm{~N} / \mathrm{A}^{1}$ & $2 / 7 / 1974$ & $<6$ & $\mathrm{~N} / \mathrm{A}^{1}$ & $2 / 7 / 1974$ & $<6$ & $\mathrm{~N} / \mathrm{A}^{1}$ \\
\hline 4/6/1974 & $<6$ & $\mathrm{~N} / \mathrm{A}^{1}$ & $4 / 6 / 1974$ & $<6$ & $\mathrm{~N} / \mathrm{A}^{1}$ & $4 / 6 / 1974$ & $<6$ & $\mathrm{~N} / \mathrm{A}^{1}$ & $4 / 6 / 1974$ & $<3$ & $\mathrm{~N} / \mathrm{A}^{1}$ & $4 / 6 / 1974$ & $<12$ & $\mathrm{~N} / \mathrm{A}^{1}$ & $4 / 6 / 1974$ & $<12$ & $\mathrm{~N} / \mathrm{A}^{1}$ & $4 / 6 / 1974$ & $<12$ & $\mathrm{~N} / \mathrm{A}^{1}$ & $4 / 6 / 74$ & $<6$ & $\mathrm{~N} / \mathrm{A}^{1}$ \\
\hline $5 / 4 / 1974$ & $<6$ & $\mathrm{~N} / \mathrm{A}^{1}$ & $5 / 4 / 1974$ & $<6$ & $\mathrm{~N} / \mathrm{A}^{1}$ & $5 / 4 / 1974$ & $<6$ & $\mathrm{~N} / \mathrm{A}^{1}$ & $5 / 4 / 1974$ & $<6$ & $\mathrm{~N} / \mathrm{A}^{1}$ & $5 / 4 / 1974$ & $<6$ & $\mathrm{~N} / \mathrm{A}^{1}$ & $5 / 4 / 1974$ & $<6$ & $\mathrm{~N} / \mathrm{A}^{1}$ & $5 / 4 / 1974$ & $<6$ & $\mathrm{~N} / \mathrm{A}^{1}$ & $5 / 4 / 1974$ & $<6$ & $\mathrm{~N} / \mathrm{A}^{1}$ \\
\hline $6 / 6 / 1974$ & $<6$ & $N / A^{1}$ & $6 / 6 / 1974$ & $<6$ & $\mathrm{~N} / \mathrm{A}^{1}$ & $6 / 6 / 1974$ & $<6$ & $N / A^{1}$ & $6 / 6 / 1974$ & $<6$ & $\mathrm{~N} / \mathrm{A}^{1}$ & $6 / 6 / 1974$ & $<6$ & $\mathrm{~N} / \mathrm{A}^{1}$ & $6 / 6 / 1974$ & $<6$ & $\mathrm{~N} / \mathrm{A}^{1}$ & $6 / 6 / 1974$ & $<6$ & $\mathrm{~N} / \mathrm{A}^{1}$ & $6 / 6 / 1974$ & $<6$ & $N / A^{1}$ \\
\hline $7 / 8 / 1974$ & $<3$ & $\mathrm{~N} / \mathrm{A}^{1}$ & $7 / 8 / 1974$ & $<6$ & $\mathrm{~N} / \mathrm{A}^{1}$ & $7 / 8 / 1974$ & $<6$ & $\mathrm{~N} / \mathrm{A}^{1}$ & $7 / 8 / 1974$ & $<6$ & $\mathrm{~N} / \mathrm{A}^{1}$ & $7 / 8 / 1974$ & $<6$ & $\mathrm{~N} / \mathrm{A}^{1}$ & $7 / 1 / 1974$ & $<6$ & $\mathrm{~N} / \mathrm{A}^{1}$ & $7 / 1 / 1974$ & $<6$ & $\mathrm{~N} / \mathrm{A}^{1}$ & $7 / 1 / 1974$ & $<6$ & $\mathrm{~N} / \mathrm{A}^{1}$ \\
\hline $8 / 5 / 1974$ & $<6$ & $\mathrm{~N} / \mathrm{A}^{1}$ & $8 / 5 / 1974$ & $<6$ & $\mathrm{~N} / \mathrm{A}^{1}$ & $8 / 5 / 1974$ & $<6$ & $\mathrm{~N} / \mathrm{A}^{1}$ & $8 / 5 / 1974$ & $<6$ & $\mathrm{~N} / \mathrm{A}^{1}$ & $8 / 5 / 1974$ & $<6$ & $\mathrm{~N} / \mathrm{A}^{1}$ & $8 / 5 / 1974$ & $<6$ & $\mathrm{~N} / \mathrm{A}^{1}$ & $8 / 5 / 1974$ & $<6$ & $\mathrm{~N} / \mathrm{A}^{1}$ & $8 / 5 / 1974$ & $<6$ & $\mathrm{~N} / \mathrm{A}^{1}$ \\
\hline 9/2/1974 & $<6$ & $\mathrm{~N} / \mathrm{A}^{1}$ & $9 / 2 / 1974$ & $<6$ & $\mathrm{~N} / \mathrm{A}^{1}$ & $9 / 2 / 1974$ & $<6$ & $\mathrm{~N} / \mathrm{A}^{1}$ & 9/2/1974 & $<6$ & $\mathrm{~N} / \mathrm{A}^{1}$ & $9 / 9 / 1974$ & $<6$ & $\mathrm{~N} / \mathrm{A}^{1}$ & $9 / 2 / 1974$ & $<6$ & $\mathrm{~N} / \mathrm{A}^{1}$ & 9/2/1974 & $<6$ & $\mathrm{~N} / \mathrm{A}^{1}$ & $9 / 2 / 1974$ & $<6$ & $\mathrm{~N} / \mathrm{A}^{1}$ \\
\hline $10 / 14 / 1974$ & $<3$ & $N / A^{1}$ & $10 / 14 / 1974$ & $<6$ & $\mathrm{~N} / \mathrm{A}^{1}$ & $10 / 14 / 1974$ & $<6$ & $N / A^{1}$ & $10 / 14 / 1974$ & $<6$ & $\mathrm{~N} / \mathrm{A}^{1}$ & $10 / 14 / 1974$ & $<6$ & $\mathrm{~N} / \mathrm{A}^{1}$ & $10 / 14 / 1974$ & $<6$ & $\mathrm{~N} / \mathrm{A}^{1}$ & $10 / 14 / 1974$ & $<6$ & $\mathrm{~N} / \mathrm{A}^{1}$ & $10 / 14 / 1974$ & $<6$ & $\mathrm{~N} / \mathrm{A}^{1}$ \\
\hline 11/4/1974 & $<6$ & $N / A^{1}$ & $11 / 14 / 1974$ & $<6$ & $\mathrm{~N} / \mathrm{A}^{1}$ & $11 / 4 / 1974$ & $<6$ & $N / A^{1}$ & $11 / 4 / 1974$ & $<6$ & $\mathrm{~N} / \mathrm{A}^{1}$ & $11 / 4 / 1974$ & $<6$ & $\mathrm{~N} / \mathrm{A}^{1}$ & $11 / 4 / 1974$ & $<6$ & $N / A^{1}$ & $11 / 4 / 1974$ & $<6$ & $\mathrm{~N} / \mathrm{A}^{1}$ & $11 / 4 / 74$ & $<6$ & $\mathrm{~N} / \mathrm{A}^{1}$ \\
\hline $12 / 17 / 1974$ & $<6$ & $\mathrm{~N} / \mathrm{A}^{1}$ & 12/10/1974 & $<6$ & $\mathrm{~N} / \mathrm{A}^{1}$ & $12 / 10 / 1974$ & $<6$ & $\mathrm{~N} / \mathrm{A}^{1}$ & 12/9/1974 & $<6$ & $\mathrm{~N} / \mathrm{A}^{1}$ & 12/9/1974 & $<6$ & $\mathrm{~N} / \mathrm{A}^{1}$ & $12 / 9 / 1974$ & $<6$ & $\mathrm{~N} / \mathrm{A}^{1}$ & $12 / 16 / 1974$ & $<6$ & $\mathrm{~N} / \mathrm{A}^{1}$ & $12 / 2 / 1974$ & $<6$ & $\mathrm{~N} / \mathrm{A}^{1}$ \\
\hline
\end{tabular}


Table D1-1. Tank 241-A-104 Drywell Radioactivity (K counts per minute) (January 1965 to November 1986) (Drywell Data Sheets Retrieved on December 6, 2012 and SD-WM-TI-356) (2 of 2 sheets)

\begin{tabular}{|c|c|c|c|c|c|c|c|c|c|c|c|c|c|c|c|c|c|c|c|c|c|c|c|}
\hline \multicolumn{3}{|c|}{ 10-04-01 } & \multicolumn{3}{|c|}{ 10-04-04 } & \multicolumn{3}{|c|}{$10-04-05$} & \multicolumn{3}{|c|}{ 10-04-07 } & \multicolumn{3}{|c|}{$10-04-08$} & \multicolumn{3}{|c|}{ 10-04-10 } & \multicolumn{3}{|c|}{ 10-04-12 } & \multicolumn{3}{|c|}{$10-05-09$} \\
\hline Date & $\begin{array}{c}\text { Peak } \\
\text { (K cpm) }\end{array}$ & $\begin{array}{c}\text { Depth } \\
\text { (ft) }\end{array}$ & Date & $\begin{array}{c}\text { Peak } \\
\text { (K cpm) }\end{array}$ & $\begin{array}{c}\text { Depth } \\
\text { (ft) }\end{array}$ & Date & $\begin{array}{c}\begin{array}{c}\text { Peak } \\
(\mathbf{K} \text { cpm })\end{array} \\
\end{array}$ & $\begin{array}{c}\text { Depth } \\
\text { (ft) }\end{array}$ & Date & $\begin{array}{c}\text { Peak } \\
\text { (K } \mathbf{~ c p m ~}) \\
\end{array}$ & $\begin{array}{c}\text { Depth } \\
\text { (ft) }\end{array}$ & Date & $\begin{array}{c}\text { Peak } \\
\text { (K cpm) }\end{array}$ & $\begin{array}{c}\text { Depth } \\
\text { (ft) }\end{array}$ & Date & $\begin{array}{c}\text { Peak } \\
\text { (K cpm) } \\
\end{array}$ & $\begin{array}{c}\text { Depth } \\
\text { (ft) }\end{array}$ & Date & $\begin{array}{c}\text { Peak } \\
\text { (K cpm) }\end{array}$ & $\begin{array}{c}\text { Depth } \\
\text { (ft) }\end{array}$ & Date & $\begin{array}{c}\text { Peak } \\
\text { (K cpm) }\end{array}$ & $\begin{array}{c}\text { Depth } \\
\text { (ft) }\end{array}$ \\
\hline 1/13/1975 & $<3$ & $\mathrm{~N} / \mathrm{A}^{1}$ & 1/13/1975 & $<6$ & $\mathrm{~N} / \mathrm{A}^{1}$ & $1 / 13 / 1975$ & $<6$ & $\mathrm{~N} / \mathrm{A}^{1}$ & 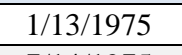 & $<6$ & $\mathrm{~N} / \mathrm{A}^{1}$ & \begin{tabular}{|l|}
$1 / 13 / 1975$ \\
\end{tabular} & $<6$ & $\mathrm{~N} / \mathrm{A}^{1}$ & $\begin{array}{l}1 / 13 / 1975 \\
\end{array}$ & $<6$ & $\mathrm{~N} / \mathrm{A}^{1}$ & 1/13/1975 & $<6$ & $\mathrm{~N} / \mathrm{A}^{1}$ & $1 / 13 / 75$ & $<6$ & $\mathrm{~N} / \mathrm{A}^{1}$ \\
\hline $7 / 14 / 1975$ & $<3$ & $\mathrm{~N} / \mathrm{A}^{1}$ & $7 / 14 / 1975$ & $<3$ & $N / A^{1}$ & 7/14/1975 & $<3$ & $N / A^{1}$ & $7 / 14 / 1975$ & $<3$ & $N / \mathrm{A}^{1}$ & $7 / 14 / 1975$ & $<3$ & $\mathrm{~N} / \mathrm{A}^{1}$ & $7 / 14 / 1975$ & $<3$ & $\mathrm{~N} / \mathrm{A}^{1}$ & 7/14/1975 & $<3$ & $N / A^{1}$ & $7 / 14 / 75$ & $<3$ & $\mathrm{~N} / \mathrm{A}^{1}$ \\
\hline $1 / 5 / 1976$ & $<3$ & $N / \mathrm{A}^{1}$ & 1510 & $<3$ & $N / A^{1}$ & $1 / 5 / 1976$ & $<3$ & $\mathrm{~N} / \mathrm{A}^{1}$ & & $<3$ & $N / A^{1}$ & $1 / 5 / 1976$ & $<3$ & $\mathrm{~N} / \mathrm{A}^{1}$ & $1 / 5 / 1976$ & $<3$ & $\mathrm{~N} / \mathrm{A}^{1}$ & $1 / 5 / 1976$ & $<3$ & $N / A^{1}$ & $1 / 5 / 76$ & $<3$ & $N / A^{1}$ \\
\hline $11 / 15 / 1976$ & $<3$ & $\mathrm{~N} / \mathrm{A}^{1}$ & $11 / 22 / 1976$ & $<3$ & $N / \mathrm{A}^{1}$ & $11 / 22 / 1976$ & $<3$ & $N / A^{1}$ & $11 / 22 / 1976$ & $<3$ & $N / \mathrm{A}^{1}$ & $11 / 22 / 1976$ & $<3$ & $\mathrm{~N} / \mathrm{A}^{1}$ & $11 / 22 / 1976$ & $<3$ & $\mathrm{~N} / \mathrm{A}^{1}$ & $11 / 22 / 1976$ & $<3$ & $\mathrm{~N} / \mathrm{A}^{1}$ & $12 / 6 / 76$ & $<3$ & $\mathrm{~N} / \mathrm{A}^{1}$ \\
\hline $6 / 21 / 1977$ & $<3$ & $\mathrm{~N} / \mathrm{A}^{1}$ & $6 / 13 / 1977$ & $<3$ & $\mathrm{~N} / \mathrm{A}^{1}$ & 6/20/1977 & $<3$ & $\mathrm{~N} / \mathrm{A}^{1}$ & $6 / 6 / 1977$ & $<3$ & $\mathrm{~N} / \mathrm{A}^{1}$ & $6 / 6 / 1977$ & $<3$ & $\mathrm{~N} / \mathrm{A}^{1}$ & $6 / 6 / 1977$ & $<3$ & $\mathrm{~N} / \mathrm{A}^{1}$ & $6 / 6 / 1977$ & $<3$ & $N / A^{1}$ & $6 / 15 / 77$ & $<3$ & $\mathrm{~N} / \mathrm{A}^{1}$ \\
\hline 10/31/1977 & $<3$ & $\mathrm{~N} / \mathrm{A}^{1}$ & $28 / 1977$ & $<3$ & $\mathrm{~N} / \mathrm{A}^{1}$ & $31 / 1977$ & $<3$ & $N / A^{1}$ & $10 / 31 / 1977$ & $<3$ & $\mathrm{~N} / \mathrm{A}^{1}$ & \begin{tabular}{|c|}
$10 / 31 / 1977$ \\
\end{tabular} & $<3$ & $\mathrm{~N} / \mathrm{A}^{1}$ & $10 / 31 / 1977$ & $<3$ & $\mathrm{~N} / \mathrm{A}^{1}$ & $10 / 31 / 1977$ & $<3$ & $\mathrm{~N} / \mathrm{A}^{1}$ & $11 / 28 / 77$ & $<3$ & $\mathrm{~N} / \mathrm{A}^{1}$ \\
\hline 12/19/1978 & $<3$ & $\mathrm{~N} / \mathrm{A}^{1}$ & $12 / 19 / 19$ & $<3$ & $\mathrm{~N} / \mathrm{A}^{1}$ & $119 / 1$ & $<3$ & $N / A^{1}$ & $12 / 19 / 1978$ & $<3$ & $\mathrm{~N} / \mathrm{A}^{1}$ & $12 / 19 / 1978$ & $<3$ & $\mathrm{~N} / \mathrm{A}^{1}$ & $12 / 19 / 1978$ & $<3$ & $\mathrm{~N} / 2$ & 12/19/1978 & $<3$ & $\mathrm{~N} / \mathrm{A}^{1}$ & $12 / 19 / 78$ & $<3$ & N/A 1 \\
\hline $12 / 17 / 1979$ & $<3$ & $\mathrm{~N} / \mathrm{A}^{1}$ & $12 / 19 / 1979$ & $<3$ & $N / \mathrm{A}^{1}$ & 12/17/1979 & $<3$ & $N / A^{1}$ & $12 / 17 / 1979$ & $<3$ & $\mathrm{~N} / \mathrm{A}^{1}$ & $12 / 19 / 1979$ & $<3$ & $\mathrm{~N} / \mathrm{A}^{1}$ & $12 / 3 / 1979$ & $<3$ & $\mathrm{~N} / \mathrm{A}^{1}$ & 12/17/1979 & $<3$ & $N / A^{1}$ & $12 / 19 / 79$ & $<3$ & $\mathrm{~N} / \mathrm{A}^{1}$ \\
\hline $10 / 7 / 1980$ & $<3$ & $\mathrm{~N} / \mathrm{A}^{1}$ & /1980 & 3 & $N / A^{1}$ & $10 / 7 / 1$ & 3 & $N / A^{1}$ & $10 / 7 / 1980$ & $<3$ & $N / A^{1}$ & $10 / 7 / 1980$ & $<3$ & $\mathrm{~N} / \mathrm{A}^{1}$ & $10 / 7 / 1980$ & $<$ & $\mathrm{N} / \mathrm{A}^{1}$ & $10 / 7 / 1980$ & $<3$ & $\mathrm{~N} / \mathrm{A}^{1}$ & $12 / 15 / 80$ & $<3$ & $\mathrm{~N} / \mathrm{A}^{1}$ \\
\hline 10/19/1981 & $<3$ & $\mathrm{~N} / \mathrm{A}^{1}$ & $10 / 19 / 1981$ & $<3$ & $N / \mathrm{A}^{1}$ & 10/19/1981 & $<3$ & $N / A^{1}$ & $10 / 19 / 1981$ & $<3$ & $\mathrm{~N} / \mathrm{A}^{1}$ & \begin{tabular}{|l|}
$10 / 19 / 1981$ \\
\end{tabular} & $<3$ & $\mathrm{~N} / \mathrm{A}^{1}$ & $10 / 19 / 1981$ & $<3$ & $\mathrm{~N} / t$ & 10/19/1981 & $<3$ & $\mathrm{~N} / \mathrm{A}^{1}$ & 10/19/81 & $<3$ & $\mathrm{~N} / \mathrm{A}^{1}$ \\
\hline $12 / 13 / 1982$ & $<3$ & $\mathrm{~N} / \mathrm{A}^{1}$ & $12 / 13 / 1982$ & $<3$ & $\mathrm{~N} / \mathrm{A}^{1}$ & $12 / 13 / 1982$ & $<3$ & $\mathrm{~N} / \mathrm{A}^{1}$ & $12 / 13 / 1982$ & $<3$ & $\mathrm{~N} / \mathrm{A}^{1}$ & $12 / 13 / 1982$ & $<3$ & $\mathrm{~N} / \mathrm{A}^{1}$ & $12 / 13 / 1982$ & $<3$ & $\mathrm{~N} / 2$ & $12 / 13 / 1982$ & $<3$ & $\mathrm{~N} / \mathrm{A}^{1}$ & $12 / 13 / 82$ & $<3$ & $\mathrm{~N} / \mathrm{A}^{1}$ \\
\hline $11 / 15 / 1983$ & $<3$ & $\mathrm{~N} / \mathrm{A}^{1}$ & $11 / 1$ & $<3$ & $\mathrm{~N} / \mathrm{A}^{1}$ & 11 & 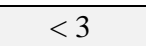 & $\mathrm{N} / \mathrm{A}^{1}$ & $11 / 15 / 1$ & $<3$ & $\mathrm{~N} / \mathrm{A}^{1}$ & $11 / 15 / 1$ & $<3$ & $\mathrm{~N} / \mathrm{A}^{1}$ & $11 / 15 / 1983$ & $<3$ & $\mathrm{~N} / t$ & 11/21/1983 & $<3$ & $\mathrm{~N} / \mathrm{A}^{1}$ & $11 / 15 / 83$ & $<3$ & $\mathrm{~N} / \mathrm{A}^{1}$ \\
\hline $11 / 15 / 1984$ & $<3$ & $\mathrm{~N} / \mathrm{A}^{1}$ & $10 / 15 / 1984$ & $<3$ & $\mathrm{~N} / \mathrm{A}^{1}$ & $11 / 15 / 1984$ & $<3$ & $\mathrm{~N} / \mathrm{A}^{1}$ & $10 / 15 / 1984$ & $<3$ & $\mathrm{~N} / \mathrm{A}^{1}$ & \begin{tabular}{|l|}
$10 / 15 / 1984$ \\
\end{tabular} & $<3$ & $\mathrm{~N} / \mathrm{A}^{1}$ & $10 / 15 / 1984$ & $<3$ & $\mathrm{~N} / \mathrm{A}^{1}$ & 10/15/1984 & $<3$ & $\mathrm{~N} / \mathrm{A}^{1}$ & $10 / 17 / 84$ & $<3$ & $\mathrm{~N} / \mathrm{A}^{1}$ \\
\hline 9/16/1985 & $<3$ & $N / \mathrm{A}^{1}$ & 9/20/1985 & $<3$ & $N / A^{1}$ & $6 / 11 /$ & $<3$ & $N / A^{1}$ & & $<3$ & $N / A^{1}$ & $6 / 11$ & $<3$ & $\mathrm{~N} / \mathrm{A}^{1}$ & $6 / 11$ & $<3$ & $\mathrm{~N} / \mathrm{A}^{1}$ & $6 / 11$ & $<3$ & $N / A^{1}$ & $9 / 16 / 85$ & $<3$ & $\mathrm{~N} / \mathrm{A}^{1}$ \\
\hline $6 / 16 / 1986$ & $<3$ & $\mathrm{~N} / \mathrm{A}^{1}$ & $11 / 13 / 1986$ & $<3$ & $\mathrm{~N} / \mathrm{A}^{1}$ & $6 / 19 / 1986$ & $<3$ & $\mathrm{~N} / \mathrm{A}^{1}$ & $6 / 19 / 1986$ & $<3$ & $\mathrm{~N} / \mathrm{A}^{1}$ & $6 / 16 / 1986$ & $<3$ & $\mathrm{~N} / \mathrm{A}^{1}$ & $6 / 16 / 1986$ & $<3$ & $\mathrm{~N} / \mathrm{A}^{1}$ & $6 / 16 / 1986$ & $<3$ & $\mathrm{~N} / \mathrm{A}^{1}$ & $11 / 13 / 86$ & $<3$ & $\mathrm{~N} / \mathrm{A}^{1}$ \\
\hline
\end{tabular}

Note: $\quad$ N/A: Data not available 


\subsection{TANK A-105 SEGMENT}

\section{TABLE OF CONTENTS}

5.1 Tank A-105 Background History .......................................................................... 5-5

5.2 Tank A-105 Operations Summary ………………............................................. 5-6

5.3 Tank Design/Construction......................................................................................

5.3.1 Tank Design ................................................................................... 5-11

5.3.2 Tank Construction Conditions ..................................................................... 5-11

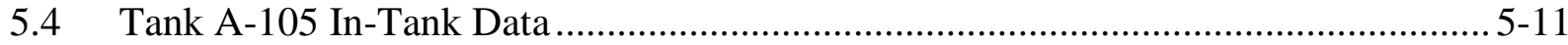

5.4.1 Liquid Level.................................................................................

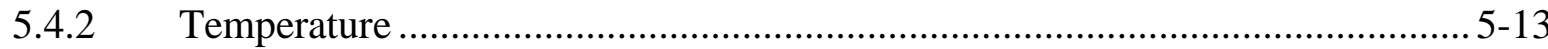

5.4.2.1. Lateral Temperatures .............................................................................. 5-14

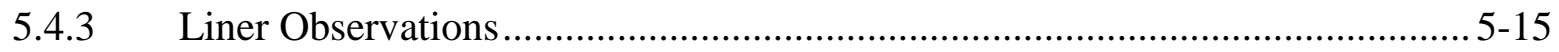

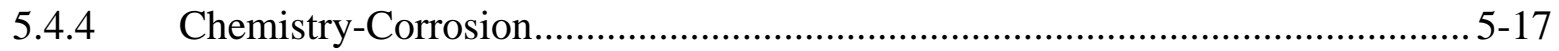

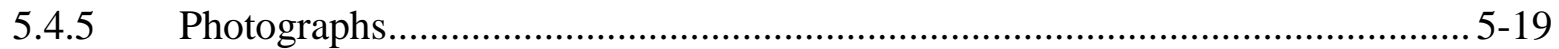

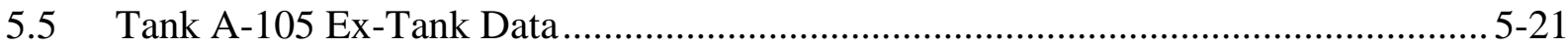

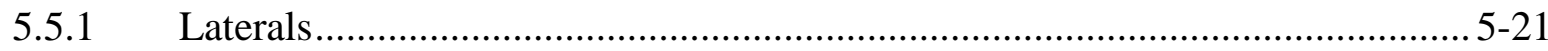

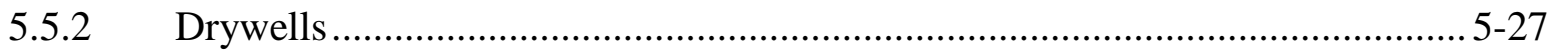

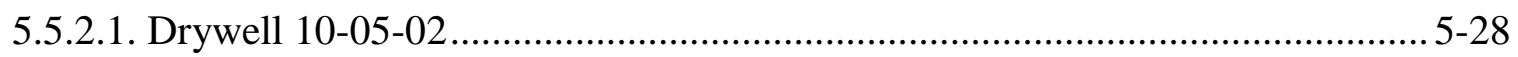

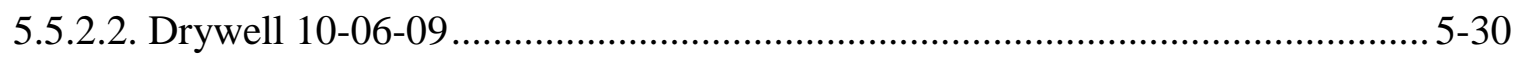

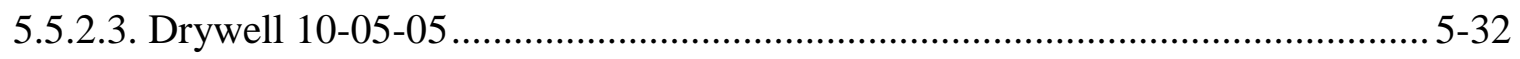

5.5.2.4. Drywell 10-05-07 .............................................................................. 5-33

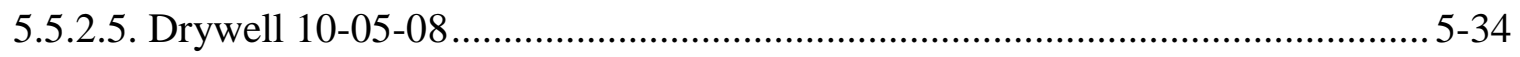

5.5.2.6. Drywell 10-04-04 .............................................................................. 5-35

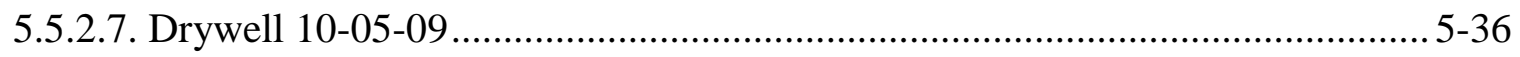

5.5.2.8. Drywell 10-05-10 ................................................................................. 5-37

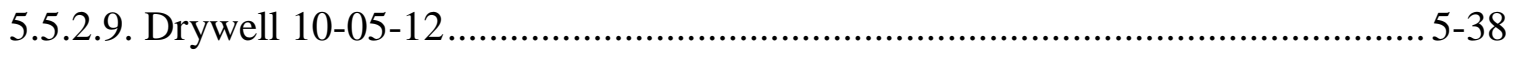

5.5.2.10. Drywell Summary ………………..................................................... 5-39

5.6 Possible Tank A-105 Liner Leak Location(s) ...................................................... 5-39

5.6.1 Leak Detected in November 1963 ............................................................ 5-40

5.6.2 Leak Detected in 1965 .......................................................................... 5-41

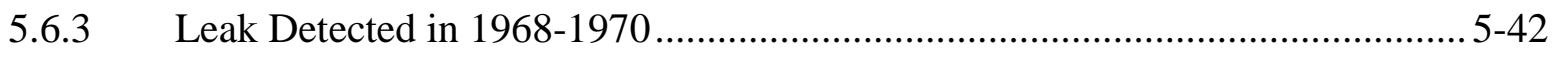

5.6.4 Leak Location Summary .......................................................................... 5-43 
5.7 Possible Tank A-105 Liner Leak Cause(s) ....................................................... 5-45

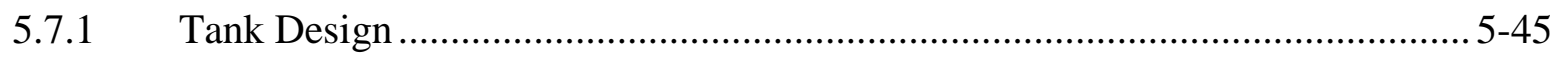

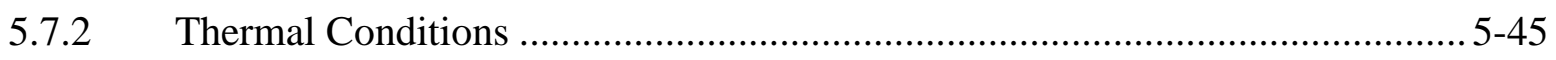

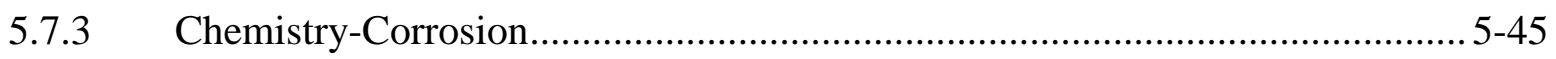

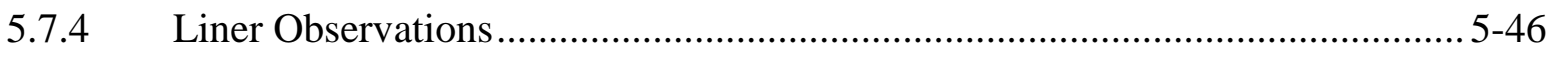

5.7.5 Tank Construction Temperature ……………........................................... 5-46

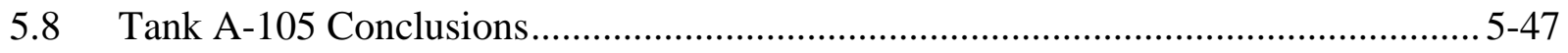

\begin{abstract}
Appendices
Appendix A2 Tank A-105 Boiling Waste Operational History............................ A2-1

Appendix B2 Tank A-105 Temperatures April 1958-June 1970_......................... B2-1

Appendix C2 Tank A-105 Lateral Activity ........................................... C2-1

Appendix D2 Tank A-105 Gross Gamma Drywell Data..................................D2-1
\end{abstract}

\title{
LIST OF FIGURES
}

Figure 5-1. Tank A-105 Associated Drywells and Laterals ..................................................... 5-5

Figure 5-2. Operational Leak History of Tank A-105 ……………................................. 5-10

Figure 5-3. Tank A-105 End of Quarter Surface Level ...................................................... 5-13

Figure 5-4. Tank A-105 Caisson \#3 Temperature Laterals (RHO-CD-255) ............................ 5-15

Figure 5-5. Tank A-105 Contour Lines on the Bulged Steel Floor Liner March 24, 1978

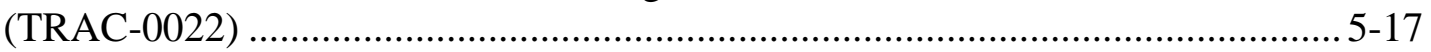

Figure 5-6. Tank A-105 ALC \#3 Photograph 0691646-21 April 16, 1969 ................................ 5-20

Figure 5-7. Tank A-105 ALC \#2 Photograph 769357-19CN October 7, 1976 ....................... 5-21

Figure 5-8. Tank A-105 Historical Lateral Radioactivity Location (WHC-EP-0412) .............. 5-22

Figure 5-9. Tank A-105 Historical Lateral Surveys (counts per second) (RPP-RPT-27605,

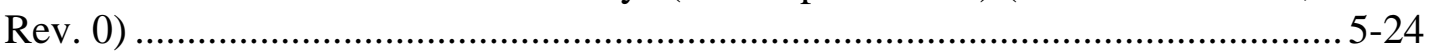

Figure 5-10. Summary Gamma Survey for Lateral 14-05-01 on Logarithmic Scale ............... 5-25

Figure 5-11. Summary Gamma Survey for Lateral 14-05-02 on Logarithmic Scale ............... 5-26

Figure 5-12. Summary Gamma Survey for Lateral 14-05-03 on Logarithmic Scale ............... 5-27

Figure 5-13. Tank A-105 Drywell 10-05-02 (RPP-8820) ……………………………….... 5-29

Figure 5-14. Drywell 10-05-02 Ruthenium Decay (RPP-8820) ............................................ 5-30 
Figure 5-15. Tank A-105 Drywell 10-06-09 (RPP-8820) ................................................... 5-31

Figure 5-16. Tank A-105 Drywell 10-05-05 (RPP-8820) ………………………………....5-32

Figure 5-17. Tank A-105 Drywell 10-05-07 (RPP-8820) ………………………………...... 5-33

Figure 5-18. Tank A-105 Drywell 10-05-08 (RPP-8820) …………………………………... 5-34

Figure 5-19. Tank A-105 Drywell 10-04-04 (RPP-8820) ……………………………....... 5-35

Figure 5-20. Tank A-105 Drywell 10-05-09 (RPP-8820) …………………………........... 5-36

Figure 5-21. Tank A-105 Drywell 10-05-10 (RPP-8820) ……………………………….... 5-37

Figure 5-22. Tank A-105 Drywell 10-05-12 (RPP-8820) ………………………………... 5-38

Figure 5-23. Tank A-105 Possible Leak Location (November 1963) ...................................... 5-40

Figure 5-24. Tank A-105 Leak Indication (1965) ................................................................. 5-41

Figure 5-25. Tank A-105 Leak Indicators (1968-1970) ...................................................... 5-42

Figure 5-26. Tank A-105 Possible Radial Leak Locations and Indicators ............................... 5-44

Figure B2-1. RHO-CD-1172 Tank A-105 Temperature April 1958 through July 1958 ......... B2-2

Figure B2-2. RHO-CD-1172 Tank A-105 Temperature August 1958 through

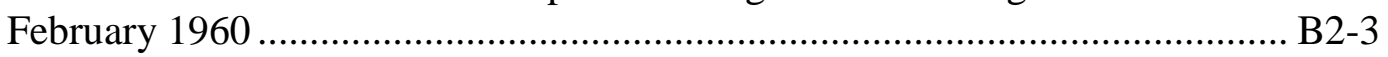

Figure B2-3. RHO-CD-1172 Tank A-105 Temperature March 1960

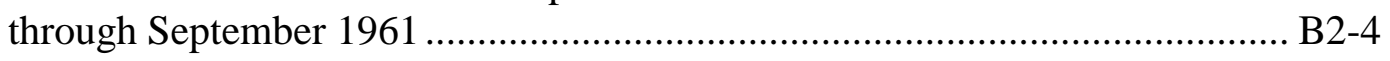

Figure B2-4. RHO-CD-1172 Tank A-105 Temperature October 1961 through April 1963 ... B2-5

Figure B2-5. RHO-CD-1172 Tank A-105 Temperature May 1963 through

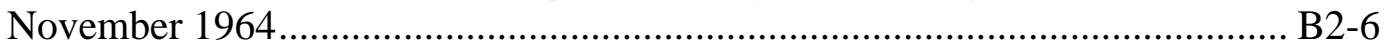

Figure B2-6. RHO-CD-1172 Tank A-105 Temperature December 1964 through

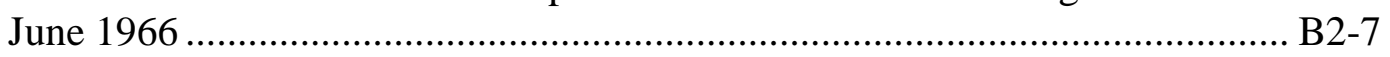

Figure B2-7. RHO-CD-1172 Tank A-105 Temperature July 1966 through January 1968 ..... B2-8

Figure B2-8. RHO-CD-1172 Tank A-105 Temperature February 1968 through August 1969

Figure B2-9. RHO-CD-1172 Tank A-105 Temperature September 1969 through June 1970 B2-9 
RPP-RPT-54912, Rev. 0

\section{LIST OF TABLES}

Table 5-1. Tank A-105 Waste Storage Chronology ….................................................... 5-18

Table 5-2. Waste Chemistries for Waste Types Stored in Tank A-105............................... 5-18

Table A2-1. RHO-R-39 Boiling Waste Tank Operating Data Table................................... A2-2

Table A2-2. ARH-R-43 Waste Tank Leak Experience Table .......................................... A2-3

Table C2-1. Tank 241-A-105 Lateral Radioactivity (K counts per minute)

(September 1972 through June 1986) ....................................................... C2-2

Table D2-1. Tank 241-A-105 Drywell Radioactivity (K counts per minute) (March 1969 to November 1986) ................................................................. D2-2 


\subsection{TANK A-105 BACKGROUND HISTORY}

This section provides information on the historical waste loss event associated with single-shell tank (SST) 241-A-105 (A-105). Tank A-105 has three laterals installed in 1962-1963 about 10-ft under the tank (see Figure 5-1). There are nine drywells located around tank A-105 with specified distances from the drywell to the tank footing shown in Figure 5-1: 10-06-09, 10-0505, 10-05-07, 10-05-08, 10-04-04, 10-05-09, 10-05-10, and 10-05-12 installed in April 1962 and 10-05-02 installed in May 1962. Three additional wells were drilled in 1965 near the north end of lateral 14-05-03 (see Section 5.5.1).

The bottom of the tank footing is $\sim 47$-ft 10-in Below Grade Surface (BGS) with 7.5-ft soil cover over the dome (WHC-SD-WM-TI-665, Soil Load above Hanford Waste Storage Tanks; H2-55911, Waste Storage Tanks Composite Section). Inside tank A-105 are four air lift circulators (ALCs) terminating 18-in above the tank bottom and equally spaced on a $40-\mathrm{ft}$ diameter circle as shown in Figure 5-1 (H-2-56350, Arrangement Air-Lift Circulators). Two ALCs are designated low ALCs (8-ft 6-in tall) and two are high ALCs (17-ft 6-in tall) (H-2-56342, Details Air-Lift Circulator).

Figure 5-1. Tank A-105 Associated Drywells and Laterals

Tank inner ring is steel liner; outer ring is outer edge of tank footing

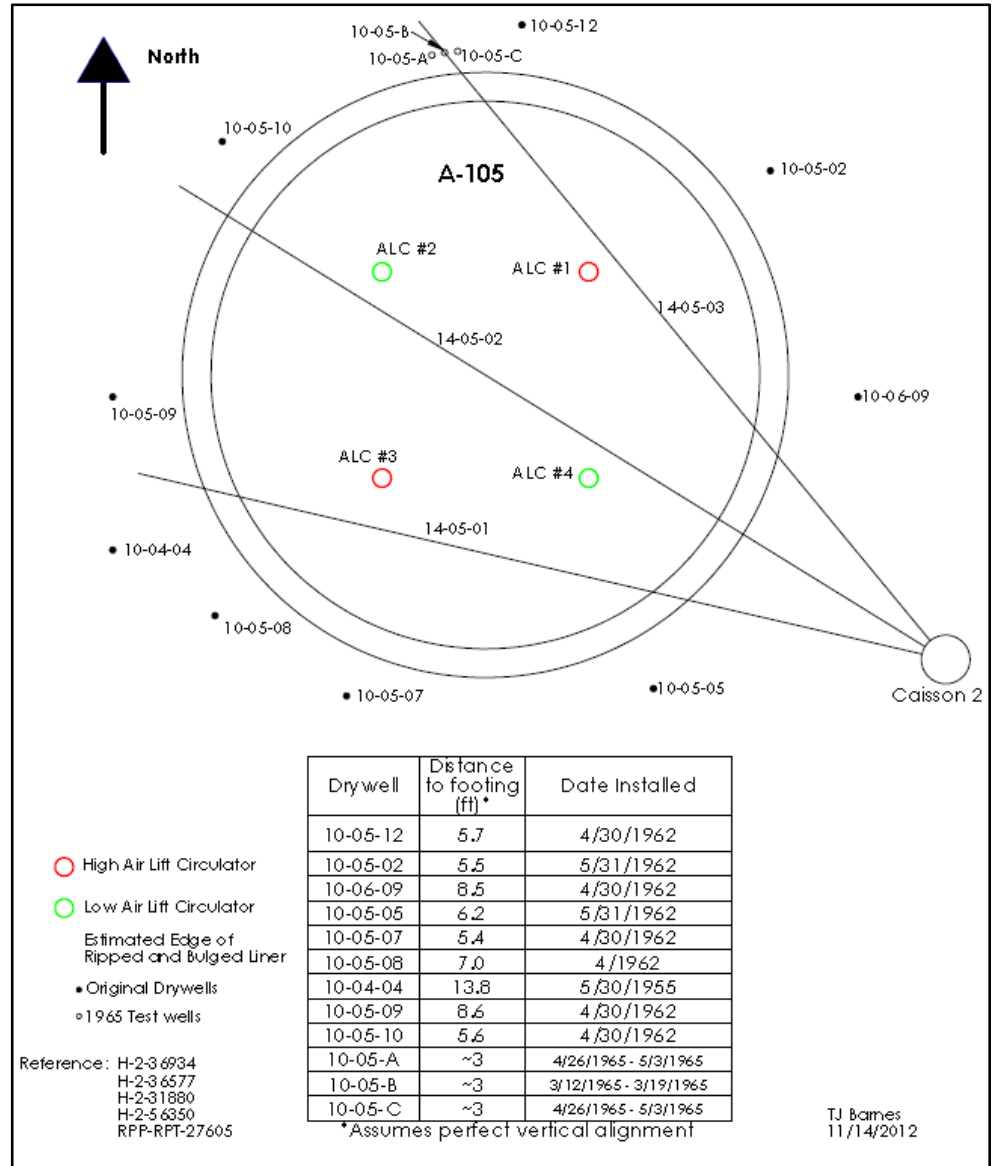


RPP-RPT-54912, Rev. 0

\subsection{TANK A-105 OPERATIONS SUMMARY}

Tank A-105 was constructed from February 1954 to January 1955 and sat unused until May 1962. After A Farm startup in 1955, each tank received 6-in of water as protection against possible bottom liner lifting from vacuum generated by the ventilation exhaust blower during equipment testing (ARH-78, PUREX TK-105-A Waste Storage Tank Liner Instability and its Implications on Waste Containment and Control). Tank A-105 liquid level gradually increased from 6-in of water in 1955 to 18-in of water in May 1962 from accumulation of water additions to various vapor seals over the seven year period.

Tank A-105 started receiving aged Plutonium Uranium Extraction (PUREX) (fuels reprocessing) Plant high level waste (HLW) supernatant from tank A-103 in May 1962. Tank A-105 received $330 \mathrm{kgal}$ of PUREX HLW supernatant over the period of 20 days during this first addition. After initially receiving waste, waste temperatures rose from approximately $115^{\circ} \mathrm{F}$ to $133^{\circ} \mathrm{F}$ over the 20 day period which may not have resulted in the complete removal of grout moisture (see Section 5.4.2). Additional aged PUREX HLW supernatant was added to tank A-105 from tanks A-103 and A-102 in December 1962 and the temperature increased to $150^{\circ} \mathrm{F}$. In January 1963 the contents of tank A-105 were pumped to tanks C-103 and A-101 leaving a 10-in heel of waste in A-105. Thermally hot condensate was added to tank A-105 to heat the tank in preparation to receive HLW directly from the PUREX Plant.

Beginning in February 1963, tank A-105 began receiving HLW directly from the PUREX Plant. Temperatures rose from approximately $110^{\circ} \mathrm{F}$ at the end of January 1963 to $210^{\circ} \mathrm{F}$ over 28 days during this time and the temperature rate of rise was $\sim 3.3^{\circ} \mathrm{F}$ per day. PUREX HLW contained significant concentrations of fission products that resulted in the waste self-boiling. Tank A-105 was brought up to boiling temperatures at a nearly uniform rate with HLW and reached boiling on March 5, 1963. Waste temperatures for tank A-105 were generally maintained between $180^{\circ} \mathrm{F}$ and $285^{\circ} \mathrm{F}$ from February 1963 through March 1965 (RHO-CD-1172, Survey of the Single-Shell Tank Thermal Histories, pages B-39 to B-45). It was reported in RPP-ENV-37956 that the maximum waste temperature was approximately $320^{\circ} \mathrm{F}$ in March 1963 for tank A- 105 . However, it appears this was an anomaly as temperatures were below $275^{\circ} \mathrm{F}$ (RHO-CD-1172) during this period and waste temperatures never reached above $300^{\circ} \mathrm{F}$ (see Figure 5-2).

In September 1963 unexplained liquid level fluctuations were noted, some as large as $33 \mathrm{kgal}$ (or 12-in) (WHC-MR-0264, Tank 241-A-105 Leak Assessment). It was assumed that these liquid level fluctuations were the result of steam forming under the tank liner and deforming it upward. As temperature levels dropped, the liquid levels dropped further supporting the steam theory (WHC-MR-0264).

On November 19, 1963, there were indications that tank A-105 developed a small leak because of radioactivity detected in lateral 14-05-03. Tank A-105 was about half filled at this time (ARH-78). Radioactivity in lateral 14-05-03 was reported to be 17,000 counts per minute (cpm) and increased to $150,000 \mathrm{cpm}$ seven days later. The tank level had been raised from 260 -in to 280-in four months earlier. It was reported in WHC-MR-0264, "This led to the assumption that 
the radiation reading in the lateral was due to a side wall leak, so the level was reduced to 260 inches. This action resulted in a slow reduction in radioactivity in the lateral, which led the operators to the conclusion that the leak was indeed in the side wall or was minor and had selfhealed." The liquid level was reduced to 260-in in December 1963 (WHC-MR-0264). From $150,000 \mathrm{cpm}$ reported in November 1963, the radioactivity in lateral 14-05-03 decreased by a factor of three to approximately 50,000 cpm by March 1965 (ARH-78).

Since radioactivity in the lateral 14-05-03 decreased, it was assumed the tank was no longer leaking. Tank A-105 was then gradually filled and by October 1964, the liquid level had reached the suspected leak zone with no indication of further leakage. The tank was considered operational and was filled to capacity in December 1964 (WHC-MR-0264). In January 1965, tank A-105 contained $866 \mathrm{kgal}$ of waste. Periodic transfers of PUREX cell drainage and flush solutions were added to the tank through June 1965 when space became available in tank A-105 as a result of waste evaporation (RL-SEP-659, Chemical Processing Department Waste Status Summary January 1, 1965 through June 30, 1965).

On January 28, 1965, tank A-105 experienced a rapid pressurization event that resulted in the tank liner bulging upward as much as $81 / 2$-ft (see Section 5.4.3). Later visual inspection would show that the floor liner had separated from the wall liner around $75 \%$ of the tank's perimeter (TRAC-0022, An Estimate of Bottom Topography, Volume, and Other Conditions in Tank 105A, Hanford, Washington [Woodward-Clyde]). The maximum recorded temperature of $\sim 285^{\circ} \mathrm{F}$ was in January/February 1965 (see Figure 5-2). Radioactivity was detected in March 1965 in a small area of lateral 14-05-03 in the north portion underneath the edge of the tank. However, there was no change in the waste surface level, and the tank continued to actively store waste until February 1968. The tank liquid level was maintained between 850 to 887 kgal through January 1968 by addition of water. In October 1967, radioactivity was also detected in lateral 14-05-02 beneath tank A-105 in the northwestern portion of the tank (WHC-MR-0264). Shortly before the pressurization event, a letter written November 17, 1964 reports, "Tank 105-A now contains more waste, in terms of equivalent tons of uranium production, than any other tank" (RL-SEP87, PUREX Waste Tank 241-A-105 Fill Limit). Also stated in RL-SEP-87 was the recommendation that HLW additions to tank A-105 should be stopped when the tank contains waste representing 11,000 tons of uranium production, which was $22 \%$ higher than the amount added to any prior filled waste tank. The basis for filling tank A-105 used an 8M sodium ion limit to indirectly control the waste temperature during the fill period (HW-74914, PUREX Tank Farm Fill Program).

In April 1967, a cyclic liquid level variation began to occur in tank A-105 (ARH-78). A typical cycle consisted of a 9 to 10-in drop in liquid level in a matter of minutes followed by a relatively stable period lasting about 20 hours. The liquid level then gradually returned to its original level in about a day. No significant movement of the steel liner could be detected during this time. It was assumed the explanation for this cyclic liquid level variation was due to the area between the bulged tank liner and concrete pad alternating between a vapor and liquid phase (ARH-78). 
In February 1968, the supernatant in tank A-105 was transferred out of the tank to tank A-103 (leaving approximately 1-ft of supernatant cover over the sludge at the bulged area) and eventually to the 221-B Plant for cesium recovery processing (Interoffice Memorandum 7G42006-004, "Estimation of Tank 241-A-105 Supernatant Cesium-137 Concentration during Sluicing in August 1968"). The residual PUREX HLW supernatant in tank A-105 was subsequently diluted using dilute waste from tank A-101 from February 25, 1968 through March 24, 1968. From April 20, 1968 through June 1968, cesium denuded supernatant from 221-B Plant operations was used to further dilute seven times the supernatant heel in tank A-105 in preparation for sluicing the sludge. The Cs-137 concentration in the cesium denuded supernatant from 221-B Plant used to dilute the HLW supernatant in tank A-105 was an average of 1.38 $\mathrm{Ci} /$ gal (0.58 Ci/gal decay corrected to January 2006) (Interoffice Memo 7G420-06-004). The flushes of the supernatant heel in tank A-105 were transferred to tank A-103, then to tank AX102 , and finally to 221-B Plant for cesium recovery processing.

Following the dilution and flushing of tank A-105 supernatant heel, two sluicing campaigns were conducted to remove the sludge from tank A-105. The first sluicing campaign began August 14, 1968, using the dilute supernatant in tank A-102 that was transferred to tank A-103 (Interoffice Memo 7G420-06-004). The Cs-137 concentration of the sluicing fluid was estimated to be 0.53 $\mathrm{Ci} /$ gal to $0.58 \mathrm{Ci} /$ gal (decay corrected to January 2006). The sludge sluiced from tank A-105 was transferred into tank A-103. After starting tank A-105 sluicing on August 14, 1968, radioactivity in laterals 14-05-01 and 14-05-02 initially increased. After three weeks, radiation levels in laterals 14-05-01 and 14-05-02 were reported to be relatively stable and sluicing continued (see Section 5.5.1). Sluicing of tank A-105 was halted in November 1968 when little of the remaining sludge could be removed. Approximately half of the sludge was removed during this first sluicing campaign.

Samples of the remaining sludge in tank A-105 were obtained and tested to evaluate methods to expedite further sludge removal from this tank. Inhibited $1 \mathrm{M} \mathrm{H}_{2} \mathrm{SO}_{4}$ was demonstrated to effectively soften the tank A-105 sludge samples (Internal Letter from W. C. Schmidt and P. W. Smith to R. E. Smith, "Dissolution of TK-105-A Sludge with Inhibited Sulfuric Acid," December 23, 1968).

As stated in ARH-1515, Atlantic Richfield Hanford Company Semiannual Report Process Development May 1, 1969 through October 31, 1969, page 130,

"Approximately 750 gallons of $1 M$ sulfuric acid, containing 1,500 ppm of the inhibitor, Rhodine A, were sprayed onto the top two-inch layer of hard cake in Tank 105-A. The acid was sprayed at $2.5 \mathrm{gpm}$ in a semi-circular pattern in the center of the tank. Following addition of the acid, this area of the tank was sluiced for 35 hours. A comparison of photographs taken before adding acid and after sluicing indicated that the sludge in the test area was successfully removed."

Cesium denuded supernatant, generated in the 221-B Plant and contained in tank A-103, was again used as the sluicing fluid. The sludge sluiced from tank A-105 was transferred into tank 
RPP-RPT-54912, Rev. 0

A-103 (Interoffice Memo 7G420-06-005, "Estimation of Tank 241-A-105 Supernatant Cesium137 Concentration during Second Sluicing Campaign Conducted July 1969 through November 1970"). No additional sludge removal activities in tank A-105 were conducted until August 25, 1970.

Inhibited sulfuric acid was again used on August 25, 1970 to soften the sludge in tank A-105. The softened sludge was then sluiced using cesium denuded supernatant contained in tank A103. The sludge slurry was transferred from tank A-105 to A-103. Following the completion of this phase of the sludge removal from tank A-105, approximately $33 \mathrm{kgal}$ of supernatant and 33 kgal of sludge were reported to remain within the tank. The supernatant contained in tank A-105 was described as being a mixture of 221-B Plant cesium ion exchange waste (i.e. cesium denuded ion exchange waste) and PUREX HLW. The estimated concentration of the cesium denuded supernatant used to conduct sluicing of tank A-105 sludge to tank A-103 from August to November 1970 was $0.51 \mathrm{Ci} /$ gal, decayed to January 2006 (Interoffice Memo 7G420-06-005). In November 1970, significant increases in radioactivity were reported for all the laterals under tank A-105 indicating that leaks were active. Therefore, sluicing operation was aborted on November 17, 1970.

In 1977 stereoscopic photographs were taken along with sludge levels and other measurements to determine the amount of sludge remaining in the tank as well as develop a topographical map of the tank bottom (TRAC-0022). The topographical map of the tank bottom produced in 1977 clearly shows the bottom of the steel liner is ripped and separated from the sidewall along approximately $3 / 4$ of the tank bottom (see Section 5.4.3 for additional details).

Following the sluicing of the waste, water was periodically added to tank A-105 from November 1970 through December 1978 for evaporative cooling of the remaining sludge. An estimated $610 \mathrm{kgal}$ of water was added to tank A-105 for cooling and flushing of the ALCs (WHC-MR0264, page 22). The estimated amount of water evaporated from tank A-105 from November 1970 through December 1978 is 378 to $410 \mathrm{kgal}$ (WHC-EP-0410, Tank 241-A-105 Evaporation Estimate 1970 through 1978). Therefore, an estimated 200 to $232 \mathrm{kgal}$ of water are unaccounted for and may have leaked from tank A-105. The estimated overall leak volume for tank A-105 is between $10 \mathrm{kgal}$ to $277 \mathrm{kgal}$, updated as of 1991 (WHC-EP-0182, Rev. 42). The estimated leak volume for the initial leak prior to August 1968 was $5 \mathrm{kgal}$ to $15 \mathrm{kgal}$, and the estimated leak volume while the tank was being sluiced August 1968 to November 1970 was between $5 \mathrm{kgal}$ and $30 \mathrm{kgal}$ (WHC-MR-0264). Tank A-105 was declared interim stabilized in March 1979.

The operational history of tank A-105 leak related details including temperature and liquid level is charted in Figure 5-2. 
Figure 5-2. Operational Leak History of Tank A-105

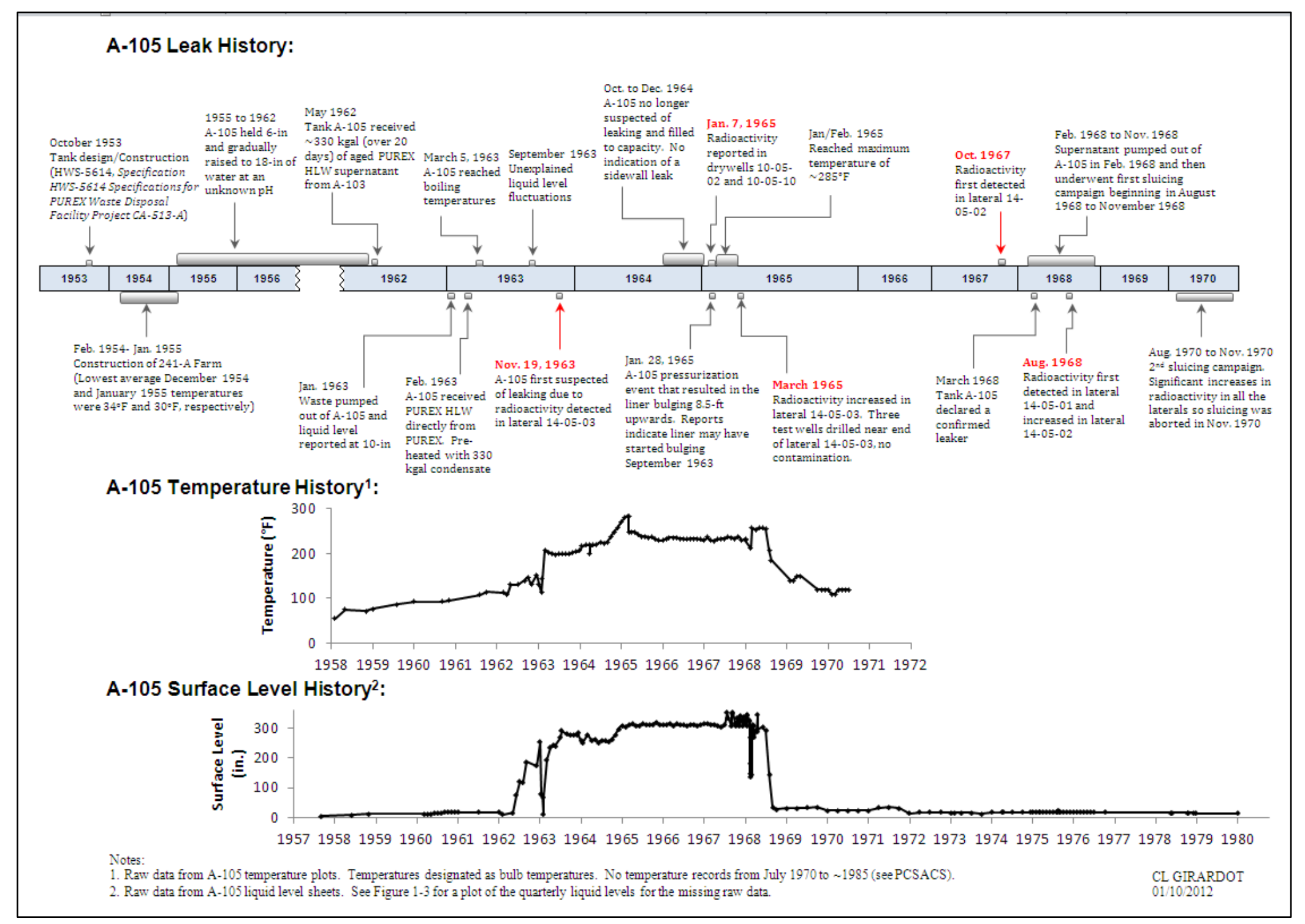


RPP-RPT-54912, Rev. 0

\subsection{TANK DESIGN/CONSTRUCTION}

\subsubsection{Tank Design}

The A Farm tanks had multiple design features that could contribute to stresses or possible leak paths when the tank was being operated including:

- Orthogonal intersection between the flat steel bottom and the sidewall

- Fillet weld used between the bottom and sidewall intersection

- Less rigorous weld inspection testing

- Partial asphaltic membrane waterproofing

These features are common to all A Farm tanks (see Section 3.1.1).

\subsubsection{Tank Construction Conditions}

A Farm was constructed from February 1954 to January 1955. Minimum temperatures of $32^{\circ} \mathrm{F}$ and below were experienced on 108 days during construction; however, no minimum temperatures below $0^{\circ} \mathrm{F}$ were experienced. The lowest average temperatures occurred in December 1954 at $34^{\circ} \mathrm{F}$ and January 1955 at $30^{\circ} \mathrm{F}$ with four months having at least one minimum temperature between $14^{\circ} \mathrm{F}$ and $18^{\circ} \mathrm{F}$ (PNNL-15160, Hanford Site Climatological Summary 2004 with Historical Data).

As described in Section 3.1.2, cold weather affects the ductile-to-brittle steel transition temperature, with $18^{\circ} \mathrm{F}$ being the assumed unrestricted low temperature construction limitation for the carbon steel liner, which could result in a fracture upon impact. Temperatures during the A Farm construction time frame were milder than those experienced during 241-SX Farm construction where ductile-to-brittle steel transition temperatures were exceeded.

Weather precautions for welding and concrete were specified in HW-4926-S, Standard Specification for Welding Carbon Steels (see Section 3.1.2).

\subsection{TANK A-105 IN-TANK DATA}

\subsubsection{Liquid Level}

Radioactivity was first detected in lateral 14-05-03 in November 1963, when the tank was half filled. Four months earlier, the liquid level in tank A-105 was raised from 260-in to 280-in. This led to the assumption that the radioactivity detected in lateral 14-05-03 was due to a sidewall leak, so the liquid level was reduced to 260-in in December 1963 (WHC-MR-0264). This action resulted in a slow reduction in radioactivity in lateral 14-05-03. It was concluded that the leak was indeed a sidewall leak or was minor and had self-healed. This conclusion and the fact that no storage capacity was available to receive the tank contents resulted in a decision to maintain the tank at this level. The tank remained in standby condition until enough water had boiled off to reach the maximum allowable salt concentration limit. 
Prior to radioactivity being detected in lateral 14-05-03, unexplained liquid level fluctuations were noted in September 1963, some increases as large as 12-in (33 kgal). Document WHCMR-0264 reports, "This indicates that steam was probably forming under the tank liner and deforming it upward at this early date. In one case, following an unexplained rise in the tank level, the data indicated that a drop in level was associated with a temperature drop, further supporting the steam theory."

With the conclusion that the possible sidewall leak in tank A-105 had self-healed, tank A-105 was kept in service and by December 1964, the tank was filled to its calculated metric tons of uranium equivalent capacity of approximately 315-in (RL-SEP-87).

The tank was gradually refilled with no indication of leakage and the tank was considered operational. On January 28, 1965 when the steam release occurred in tank A-105, liquid levels were reported to be between 305-in and 320-in. Liquid levels were apparently not a focus during this time and no reports of unexplained liquid level changes were found. The tank continued to actively store waste until February 1968 with the liquid level maintained between 850 to 887 kgal by addition of water. In April 1967, a cyclic liquid level variation began to occur in tank A105 (ARH-78). A typical cycle consisted of a 9 to 10-in drop in liquid level in a matter of minutes followed by a relatively stable period lasting about 20 hours. The liquid level then gradually increased to its original level in about a day. No significant movement of the steel liner could be detected during this time. It was assumed the explanation for this cyclic liquid level variation was due to the area between the bulged tank liner and its concrete pad alternates between a vapor and liquid phase (ARH-78).

From February to August 1968, the supernatant was pumped out of tank A-105 in preparation for the first sluicing campaign leaving the liquid level at approximately 35 -in.

The liquid level plot in Figure 5-3 indicates the transfers into and out of the tank. The liquid levels are end of quarter levels so this figure may not reflect all significant transfers into and out of tank A-105 that occurred during the operational history of the tank. See Figure 5-2 for historical monthly liquid level readings. 
RPP-RPT-54912, Rev. 0

Figure 5-3. Tank A-105 End of Quarter Surface Level

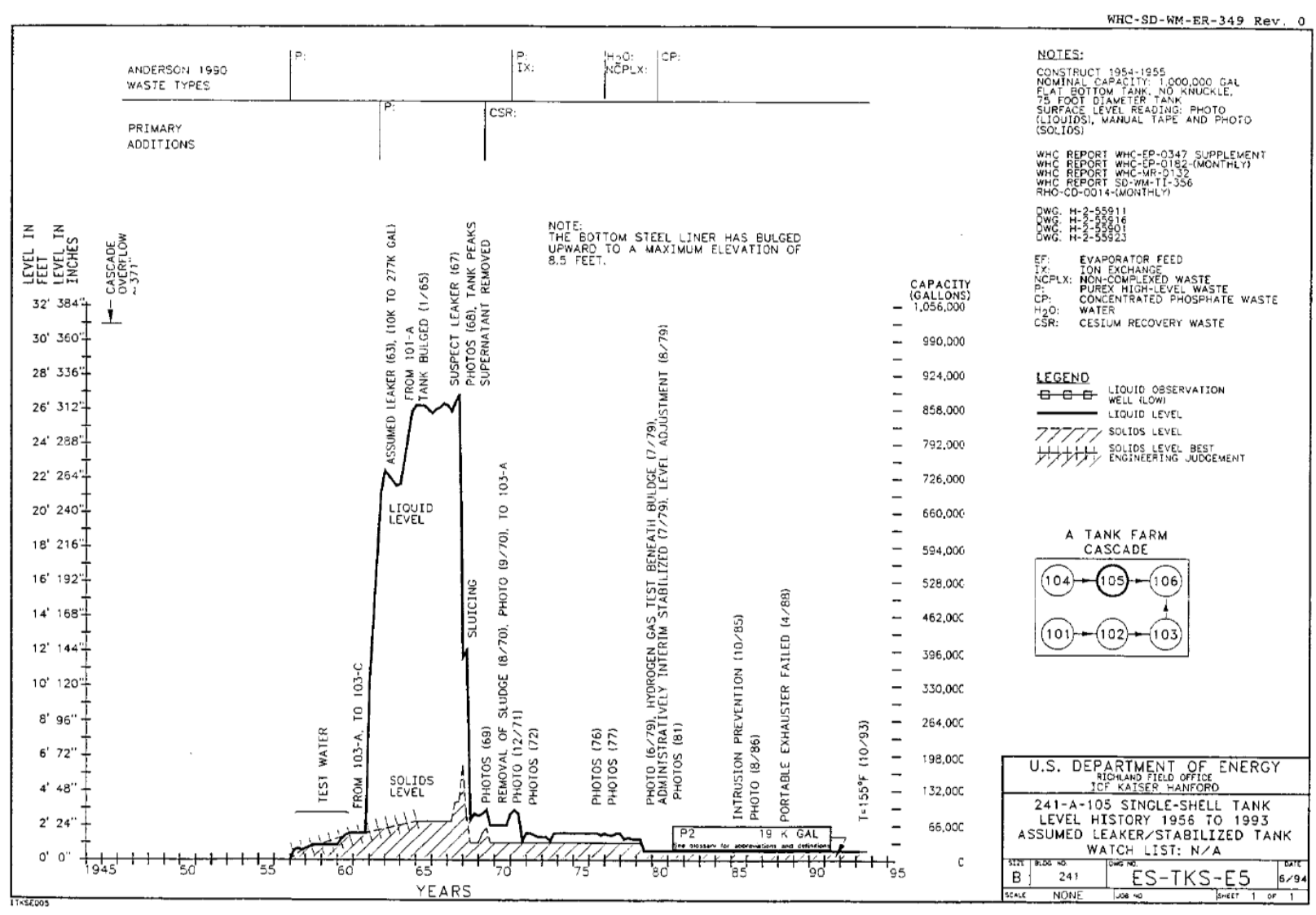

WHC-SD-WM-ER-349, Rev 0, June 1994, Historical Tank Content Estimate for the Northeast Quadrant of the Hanford 200 East Area

\subsubsection{Temperature}

Document HW-59919 issued October 22, 1959 (Limitations for Existing Storage Tanks for Radioactive Wastes from Separations Plants) states that tank contents should be heated slowly to not exceed the recommended rate of $2^{\circ} \mathrm{F}$ per day along with other temperature requirements for filling boiling waste tanks. The temperature requirements for filling boiling waste tanks are designed to provide enough time at controlled temperature and other waste parameters (specific gravity and liquid depth) to remove grout moisture gradually so that the grout moisture vapor pressure does not exceed the hydrostatic pressure. Bulging of the tank bottom liner can be caused by grout vapor pressure exceeding the hydrostatic pressure.

Tank A-105 was initially filled with water and sat unused until May 1962. Temperatures during this time ranged from $60^{\circ} \mathrm{F}$ to $115^{\circ} \mathrm{F}$ (see Appendix B2). Beginning in May 1962, tank A-105 was initially filled with aged PUREX HLW supernatant and temperatures rose to approximately $150^{\circ} \mathrm{F}$. The tank A-105 HLW supernatant was transferred out leaving a 10-in heel in January 1963. Beginning in January 1963, heating of tank A-105 was initiated by the addition of thermally hot condensate in preparation for receipt of PUREX self-boiling waste (WHC-MR0264). After addition of PUREX self-boiling waste, tank A-105 reached boiling temperatures on March 5, 1963. Waste temperatures for tank A-105 were generally maintained between $180^{\circ} \mathrm{F}$ to $285^{\circ} \mathrm{F}$ from February 1963 through January 1965 (RHO-CD-1172, Survey of the Single-Shell 
Tank Thermal Histories, pages B-39 to B-45). It was reported in RPP-ENV-37956 that the maximum waste temperature was approximately $320^{\circ} \mathrm{F}$ in March 1963 for tank A-105. However, it appears this was a reporting anomaly as temperatures were below $275^{\circ} \mathrm{F}$ during this period and waste temperatures never reached above $300^{\circ} \mathrm{F}$ during operation (see Figure 5-2).

On January 28, 1965, tank A-105 experienced a rapid pressurization event that resulted in the tank liner bulging. During this time, waste temperatures increased from $270^{\circ} \mathrm{F}$ to the maximum temperature of approximately $285^{\circ} \mathrm{F}$ in January and February 1965 (see Figure 5-2). On March 11,1965 , when the bulb thermocouple was replaced, temperatures were reported to be approximately $250^{\circ} \mathrm{F}$ and remained relatively stable through June 1968 . Temperatures then started to decline after removal of the tank A-105 supernatant in preparation for the sluicing with a temperature of $120^{\circ} \mathrm{F}$ recorded in June 1970. Waste temperatures for tank A-105 were recovered from May 1958 through June 1970 (see Appendix B2); however, no temperature data were recovered after June 1970 until 1985 (see Figure 5-2).

Document HW-59919 indicated that the self-boiling waste operating temperature should be maintained between $220^{\circ} \mathrm{F}$ and $250^{\circ} \mathrm{F}$ (see Section 3.2.2). The maximum sludge temperature should not exceed $300^{\circ} \mathrm{F}$. As noted, the temperature did not exceed this level during operation.

\subsubsection{Lateral Temperatures}

A special probe was built to map the temperatures in the leak detection laterals (ARH-78) to better understand the accumulation of heat producing sludge under the bulged failed liner. The maximum temperature $\left(310^{\circ} \mathrm{F}\right)$ was found in lateral $14-05-03$ in the north portion of the tank. Periodic measurements were made in all three laterals after the steam eruption in January 1965 in 1965 and 1966 and by October 1966 all three lateral maximum temperatures ranged between $205^{\circ} \mathrm{F}$ and $220^{\circ} \mathrm{F}$.

Four temperature laterals were later drilled 2-ft under tank A-105 with fixed thermocouples from caisson \#3 located southwest of the tank (see Figure 5-4). Readings began in 1968 two years after the lateral temperatures mentioned above with the highest temperature of $332^{\circ} \mathrm{F}$ observed in both the number 8 and 9 thermocouples of lateral $N 36^{\circ} 0^{\prime} \mathrm{E}$. This indicates that the temperatures two feet under the tank were probably much higher in 1965 and 1966 which would have far exceeded the concrete temperature limit of $325^{\circ} \mathrm{F}$ (RHO-CD-255, Tank 105-A

Stabilization Progress Report). 


\section{Figure 5-4. Tank A-105 Caisson \#3 Temperature Laterals} (RHO-CD-255)

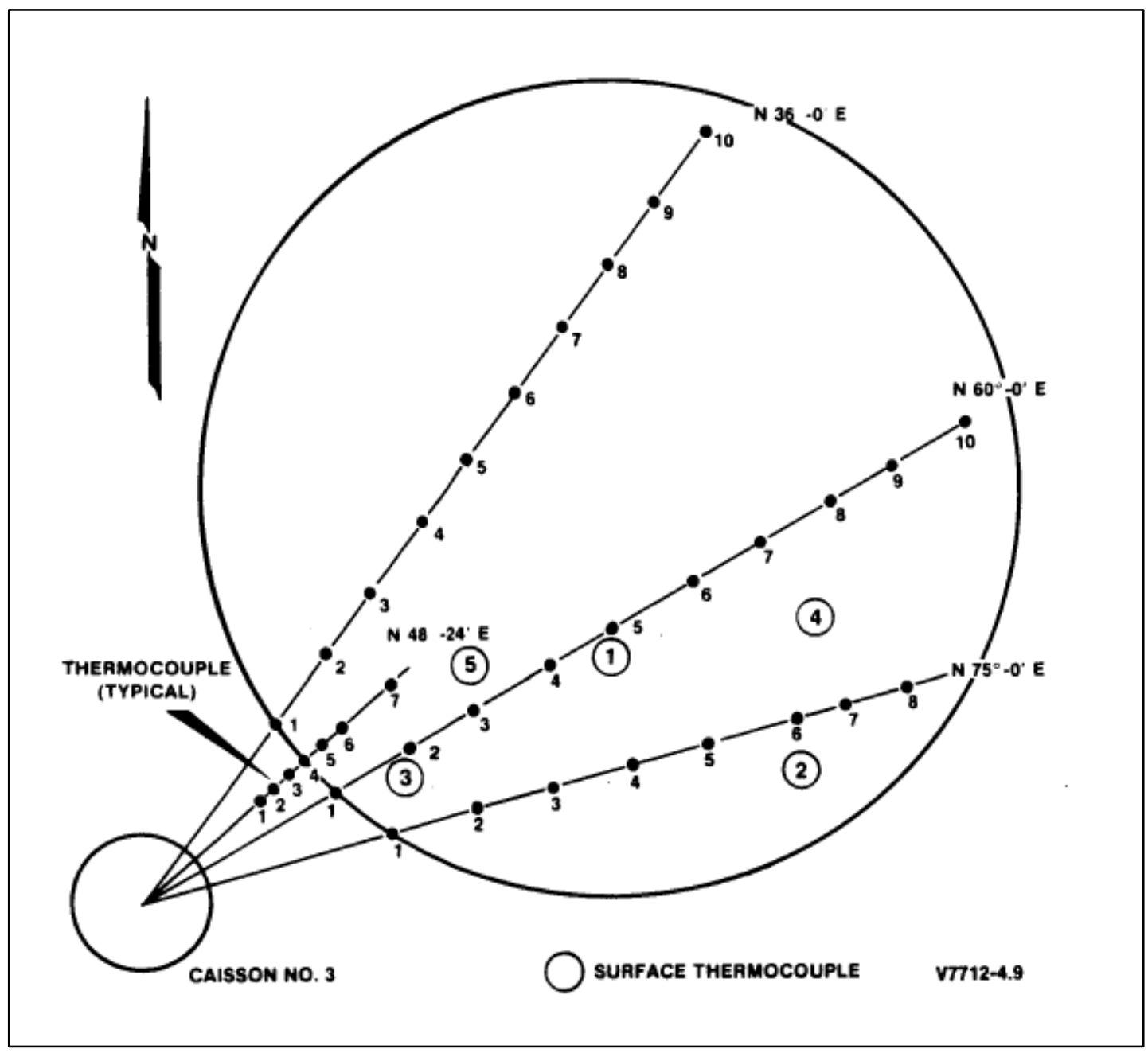

These thermocouples were no longer the hottest when the report was written in 1978 when the highest reading in lateral $\mathrm{N} 36^{\circ} 0$ ' $\mathrm{E}$ was reported at thermocouple number 3 at $215^{\circ} \mathrm{F}$. Temperatures were later found to be higher beneath the bulged area of the tank and highest beneath the sludge pile above the liner.

\subsubsection{Liner Observations}

A bulge in a tank liner may result in the direct failure of the liner or cause enough stress or thinning on the steel liner plates and welds that they become more susceptible to the effects of corrosion. Experience indicates that bulging tends to be a dynamic phenomenon, and it is possible that a tank with no measured bulge at one point in time may actually have had a displaced liner that was not detected at another time. A thinning or weakened location may be more susceptible to corrosion (see Section 3.2.3).

Aged HLW supernatant was transferred into tank A-105 in 1962 and was pumped to tanks C-103 and A-101 in January 1963 leaving a 10-in heel of waste in A-105. Tank temperatures prior to 
the transfer of supernatant may not have been high enough to drive all of the moisture out of the grout. If there was any remaining grout moisture near an estimated grout temperature of $\sim 130^{\circ} \mathrm{F}$ the vapor pressure under the tank bottom liner would be 2.2 psi. The hydrostatic pressure of 10in of waste at a 1.36 specific gravity is $\sim 0.5 \mathrm{psi}$. This results in the vapor pressure under the tank bottom liner to be greater than the hydrostatic pressure which could result in bulging of the liner. September 1963 indications of unexplained liquid level fluctuations coupled with the radioactivity detected in lateral 14-05-03 would tend to confirm bulging along with an indication of bottom liner failure that may have re-introduced moisture into the grout.

On January 28, 1965, a sudden steam release occurred in tank A-105. Report, ARH-78, PUREX TK-105-A Waste Storage Tank Liner Instability and its Implications on Waste Containment and Control, reports, "The earth in the immediate vicinity of the tank was reported to have trembled, and a temporary lead cover on a riser on TK-103-A was dislodged allowing steam to vent from this opening for about 30 minutes. A water seal in the vent system designed to relieve tank pressure at 60 inches of water was not blown." This steam event was different from previous incidents in other tanks in that the event occurred while the ALCs were reported to be in operation. The 1963 indication of bottom liner bulging and possible liner failure may have set up the conditions for trapping condensate/HLW under the liner. The trapped liquid may have ultimately become superheated under the pressure of the concentration of 11,000 tons uranium equivalent $\mathrm{HLW}$ and temperature of $285^{\circ} \mathrm{F}$ to the point of a sudden steam release under the tanks bottom liner.

While preparing to add an air sparger after the steam release event to tank A-105 to enable mixing the tank contents, an obstruction approximately eight feet above the tank floor was encountered. This obstruction had been reported several months earlier, when difficulty was encountered during the use of a sludge probe (ARH-78). This indicated that the tank floor may have bulged upward prior to the steam release (WHC-MR-0264). This indication is further supported by the unexplained increases in liquid level observed in September 1963 when the tank was first brought up to boiling temperatures.

Subsequent inspection of the inside of tank A-105 revealed deformation of part of the lower sidewall, an $81 / 2$-ft bulge in the tank liner floor near the center of the tank, and separation between the liner floor and wall as shown in Figure 5-5 (TRAC-0022). The cavity volume between the liner and the concrete shell created by this event was estimated at approximately 80 kgal (ARH-78). Following the steam event, tank A-105 continued to actively store waste. Monitoring of the tank increased significantly. In October 1967, low level radioactivity was first detected in lateral 14-05-02 underneath tank A-105. A small leak was thought to have occurred during water additions to the 350-in waste level (ARH-78). 
RPP-RPT-54912, Rev. 0

Figure 5-5. Tank A-105 Contour Lines on the Bulged Steel Floor Liner March 24, 1978 (TRAC-0022)

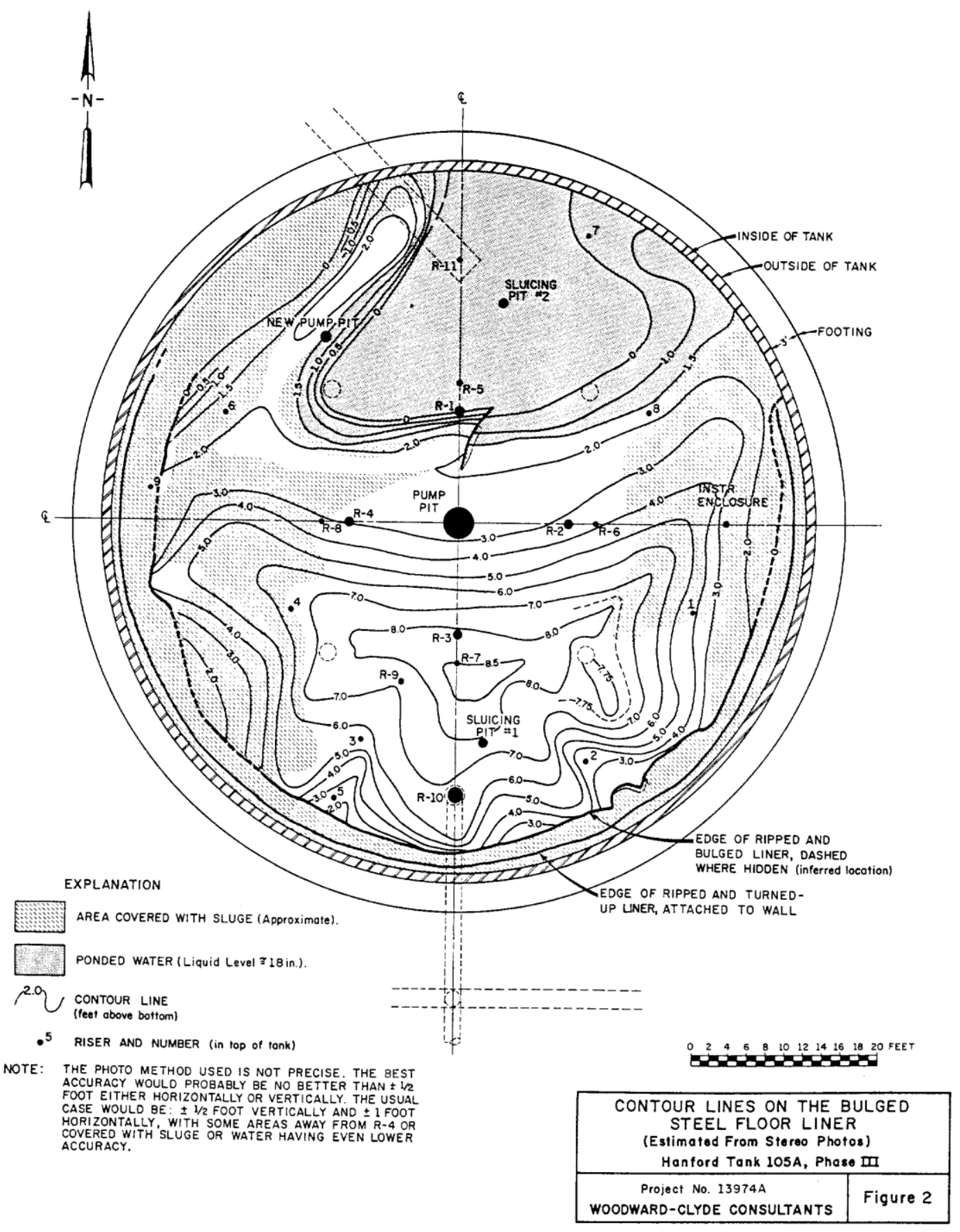

\subsubsection{Chemistry-Corrosion}

Tank A-105 first received water in 1955 and initially received PUREX HLW in 1962. Tank A105 only stored PUREX HLW throughout operation as shown in Table 5-1. The typical 
concentrations for nitrite, nitrate, and hydroxide for these waste types are shown in Table 5-2. Nitrite and hydroxide are known as nitrate-induced SCC inhibitors. One key characteristic for inhibiting SCC is to maintain a high nitrite concentration to nitrate concentration ratio (see Section 3.2.4).

Table 5-1. Tank A-105 Waste Storage Chronology

\begin{tabular}{|c|c|c|}
\hline Date & Waste Type & Length of Storage \\
\hline 1955 to 1962 & Water & $\sim 7$ years \\
\hline May 1962 to February 1968 & PUREX HLW & $\begin{array}{l}\sim 15 \text { months before leak } \\
\text { detected }(\sim 5 \text { years total })\end{array}$ \\
\hline
\end{tabular}

Table 5-2. Waste Chemistries for Waste Types Stored in Tank A-105

\begin{tabular}{|c|c|c|c|c|}
\hline Waste Types & {$\left[\mathrm{NO}_{3}{ }^{-}\right]$} & {$\left[\mathrm{NO}_{2}{ }^{-}\right]$} & {$\left[\mathrm{OH}^{-}\right]$} & $\begin{array}{c}\text { Meets Current } \\
\text { DST Specification }^{3}\end{array}$ \\
\hline PUREX HLW $^{1}$ & 1.3 & $3.37^{2}$ & Not Reported & Yes \\
\hline
\end{tabular}

1. $\quad$ Reference WHC-EP-0449, 1991, The Sort on Radioactive Waste Type Model: A Method to Sort Single-Shell Tanks into Characteristic Groups.

2. Average of three A Farm PUREX waste samples, RL-SEP-183 RD, PUREX Tank Farm Supernatant Solution Composition.

3. Reference OSD-T-151-00007, Rev. 12, 2013, Operating Specifications for the Double-Shell Storage Tanks.

Water was added to tank A-105 in 1955 to counteract the vacuum on the tank. No mention of the water source or chemical adjustment has been found in any of the documents reviewed. Some corrosion may have occurred during the seven years when only water was in the tank. The temperatures during the seven years ranged from $60^{\circ} \mathrm{F}$ to $115^{\circ} \mathrm{F}$ (see Section 5.4.2). In 1962 PUREX HLW was added to the water which provided corrosion protection.

Tank A-105 started receiving aged PUREX HLW in May 1962. In January 1963, tank A-105 HLW supernatant from tanks A-101 and A-103 was pumped out of the tank leaving the liquid level reported at 10-in (see Section 5.2). At the end of January 1963, condensate was added to tank A-105 in order to pre-heat the tank prior to receiving PUREX HLW directly from PUREX. The condensate was reported in 1960 to be normally at approximately pH 9 (HW-67698, Preliminary Report on the Characterization of PUREX Tank Farm Radioactive Condensate Waste). Caustic was to be added to the condensate tank when off standard operating conditions occurred to maintain the condensate $\mathrm{pH}$ above seven in 1965 (RL-SEP-239, page 5.2-1). Earlier specifications could not be found that addressed the $\mathrm{pH}$ of condensate.

Tank A-105 stored aged PUREX HLW supernatant for approximately eight months and PUREX HLW for seven months prior to November 1963, when radioactivity was initially detected in one of the laterals. Under flowsheet conditions PUREX HLW would not be considered to have a high propensity for corrosion of the tank steel liner. One incidence of tank farm condensate recycle to tank A-105 of approximately $330 \mathrm{kgal}$ on a supernatant heel of $8 \mathrm{kgal}$ may have resulted in lower $\mathrm{pH}$ and nitrate concentrations for a period of time. 


\subsubsection{Photographs}

Earliest available photographs of tank A-105 taken on August 28 and 29, 1968 were reviewed. The steam eruption and resulting liner bulge of $81 / 2$-ft occurred in January 1965 and no photographs were taken during this time. One photograph of a bent ALC with the bottom liner raised beneath the ALC is shown in Figure 5-6 that was taken in April 1969. As a result of the steam eruption, it appears two of the ALCs were tilted off vertical significantly questioning their efficiencies after 1965. However, the ALCs may have been affected during the 1963 liquid level fluctuations which may have indicated periodic bulging of the bottom liner. Air flow to the ALCs was increased to the maximum and waste temperatures were apparently controlled as they remained below $300^{\circ} \mathrm{F}$ (see Figure 5-2).

A photograph taken October 7, 1976 (see Figure 5-7) shows ALC \#2 that remains relatively intact after the steam eruption with all the turnbuckle guy rods attached. In Figure 5-7, it appears the torn liner can be seen in front of the ALC and the existing gap between the two torn steel pieces as noted in TRAC-0022.

A review of the available photographs confirms the liner bulge of tank A-105; however, it remains unclear from the available photographs the entire extent of the ripped liner. 
RPP-RPT-54912, Rev. 0

Figure 5-6. Tank A-105 ALC \#3 Photograph 0691646-21

April 16, 1969

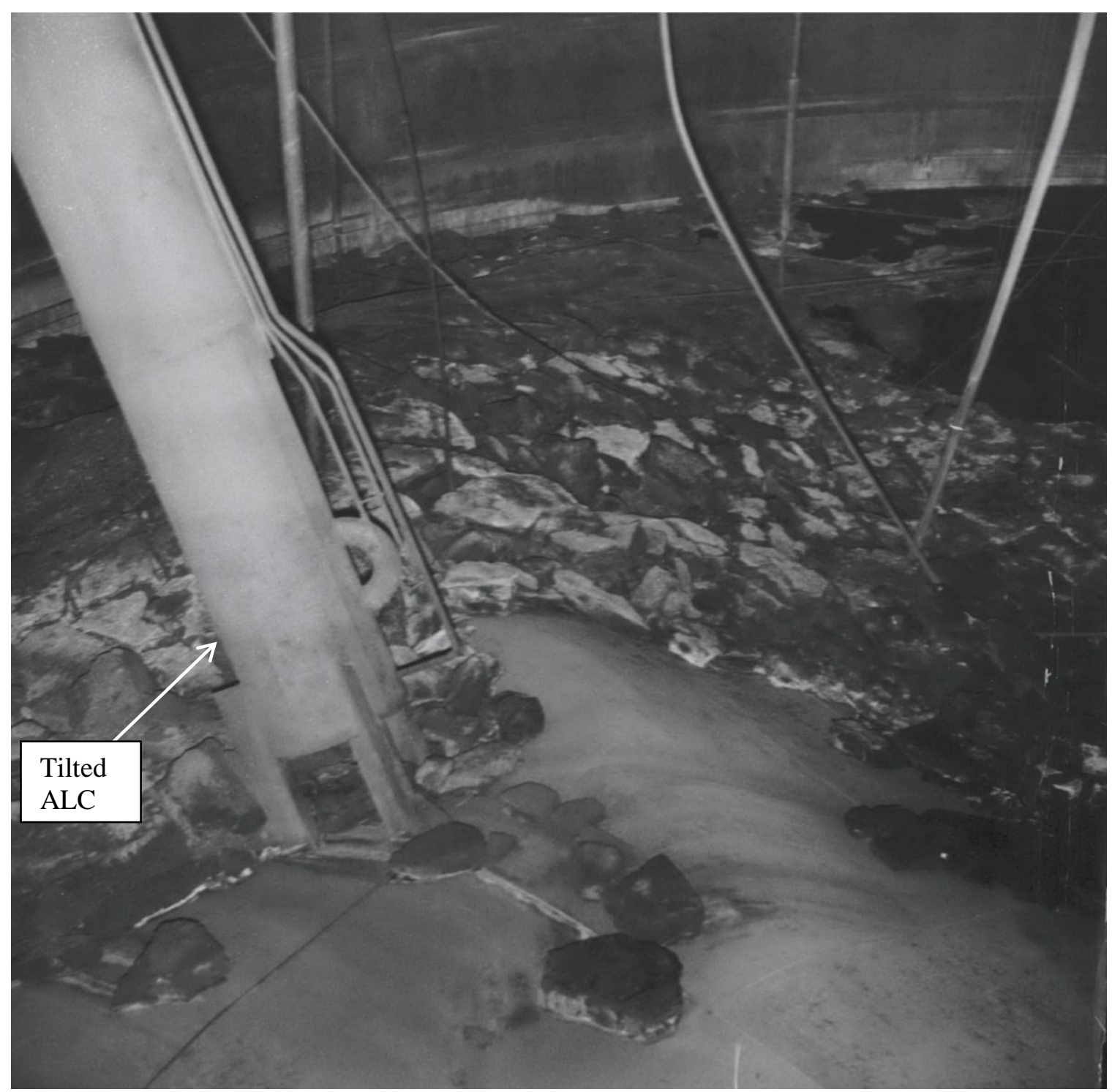




\section{Figure 5-7. Tank A-105 ALC \#2 Photograph 769357-19CN}

October 7, 1976

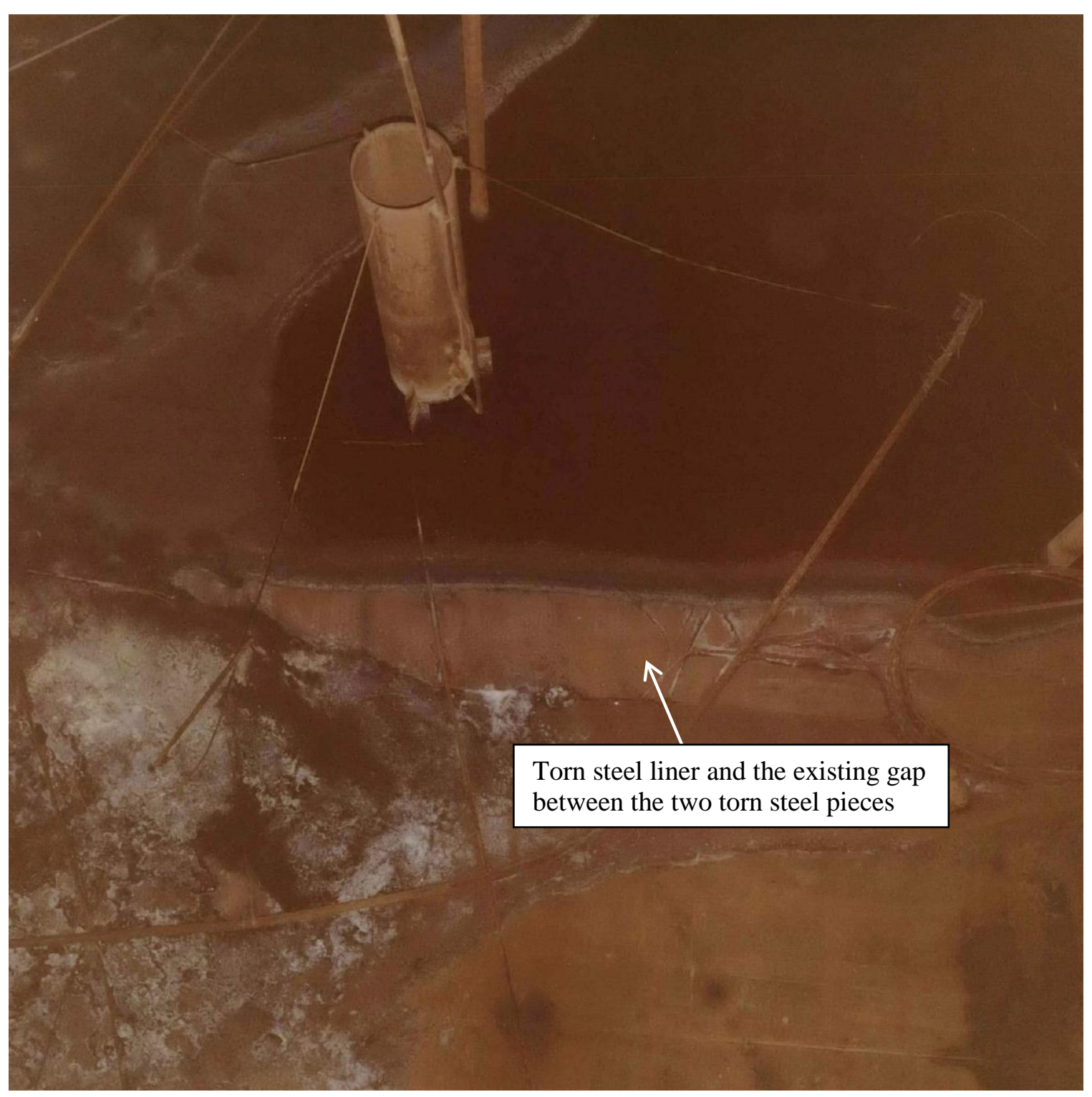

\subsection{TANK A-105 EX-TANK DATA}

\subsubsection{Laterals}

The first indication of a tank A-105 leak occurred in November 1963 when elevated gross gamma levels were measured over a small segment in lateral 14-05-03 (see Appendix C2) on the southeast side of the tank as shown in Figure 5-8. Initial readings were $17 \mathrm{~K} \mathrm{cpm}$ and continued to increase to $150 \mathrm{~K} \mathrm{cpm}$ a week later. Subsequently, radiation readings decreased to approximately $50 \mathrm{~K}$ cpm by March 1965 indicating that the predominant gamma-emitting radionuclides were short-lived (ARH-78). During this time it was assumed radioactivity detected in lateral 14-05-03 was due to a sidewall leak between 260-in and 280-in (see Section 
5.4.1). However, after additional waste was added in 1964 bringing the waste level above 280in, no recurrence of contamination was detected in lateral 14-05-03. If a sidewall leak had occurred, it apparently self-healed. No radioactivity was detected in the other laterals or drywells during this time.

Figure 5-8. Tank A-105 Historical Lateral Radioactivity Location (WHC-EP-0412)

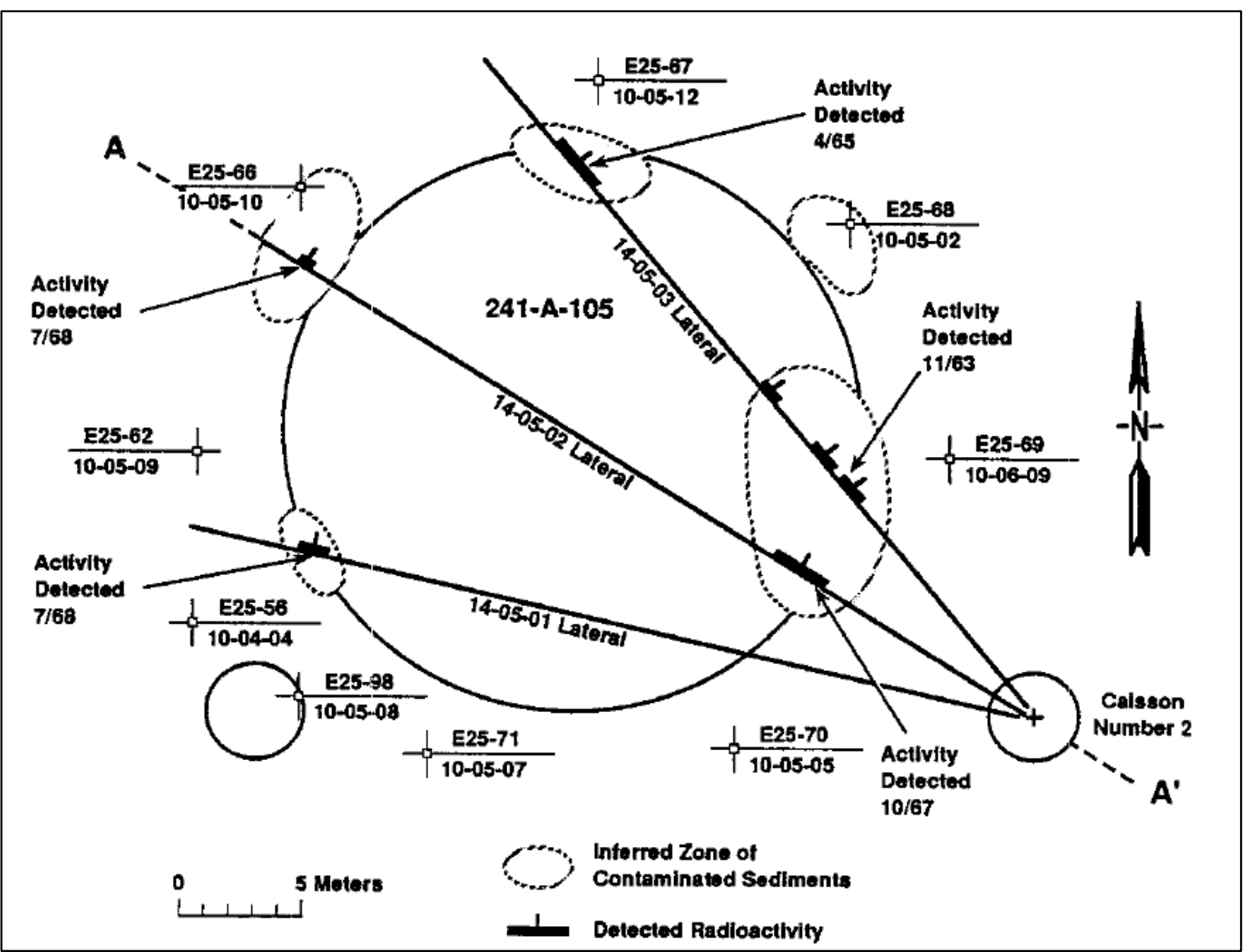

Note: The dates of lateral radioactivity increases and stabilization during August 1968 conflict between document WHC-MR-0264 and WHC-EP-0412 and Interoffice Memorandum 7G420-06-004.

The next reported waste loss occurred on January 28, 1965 when a sudden steam release occurred in tank A-105 (see Section 5.4.3). As a result of this event, it was reported the tank bottom liner bulged upwards $81 / 2$-ft near the center of the tank with separation of the steel bottom and wall. Subsurface contamination was detected March 8, 1965 at $195 \mathrm{~K} \mathrm{cpm}$ in lateral 14-0503 in the north portion of the tank (see Figure 5-8). Three test wells were drilled near the end of lateral 14-05-03 to a depth of about 65-ft, or 10-ft below the tank bottom (see Figure 5-23). Soil samples taken from the test wells showed no radioactivity (RL-SEP-509, page G-2) indicating contamination was likely localized. 
On October 2, 1967, low level radioactivity (approximately $2 \mathrm{~K} \mathrm{cpm}$ ) was first detected in lateral 14-05-02 underneath the southeastern portion of the tank as shown in Figure 5-8. A small leak was thought to have occurred during water additions to the 350-in waste level (ARH-78). The dates of lateral radioactivity increases and stabilization during August 1968 conflict between documents WHC-MR-0264 and WHC-EP-0412 and Interoffice Memorandum 7G420-06-004. Document WHC-MR-0264 reported an initial increase in radiation levels in laterals 14-05-01 and 14-05-02 in August 1968 immediately after initial sluicing operations began (August 14, 1968) for purposes of removing sludge still present in the tank above the liner. However, document WHC-EP-0412 indicated the occurrence of elevated radiation readings in July 1968 in two tank perimeter locations near the ends of laterals 14-05-01 and 14-05-02 (see Figure 5-8). Radioactivity increases in these laterals on August 19, 1968 were confirmed by Interoffice Memo 7G420-06-004. After 3 weeks, radiation levels at laterals 14-05-01 and 14-05-02 were holding steady at $20 \mathrm{~K}$ and $190 \mathrm{~K}$ cpm, respectively (WHC-MR-0264). However, it was reported in Interoffice Memo 7G420-06-004 that radioactivity in lateral 14-05-02 continued to increase and leveled off at $410 \mathrm{~K}$ cpm three weeks after sluicing had begun in tank A-105. Sluicing operations likely caused increased leakage from the tank, probably by loosening and removing solid build-ups at the leak site(s). Sluicing of tank A-105 was halted when little of the remaining sludge could be removed. On October 29, 1968, the activity-measuring instrument was repaired leaving the radioactivity reported in laterals $14-05-01,14-05-02$, and $14-05-03$ as $20 \mathrm{~K}, 190 \mathrm{~K}$, and $120 \mathrm{~K}$ cpm, respectively (WHC-MR-0264).

The second sluicing campaign for tank A-105 began August 25, 1970 and ran until November 1970. In August 1970, all laterals showed increased readings compared with the October 1968 readings. Radioactivity increased to $40 \mathrm{~K}$ cpm in lateral $14-05-01,375 \mathrm{~K} \mathrm{cpm}$ in lateral $14-05-02$, and $960 \mathrm{~K} \mathrm{cpm}$ in lateral 14-05-03. These fluctuations indicated that leaks were active and since readings remained high, the sluicing operation was aborted on November 17, 1970 (WHC-MR0264). In May 1978, a radiation spike from $516 \mathrm{~K}$ cpm to $1,080 \mathrm{~K}$ cpm occurred in lateral 14-0503 (see Appendix C2). A large nearby water line spill in February 1978 of $60 \mathrm{kgal}$ that redistributed mobile gamma-emitting contaminants already present in the vadose zone appears to have been the most likely cause of this contamination increase. See Figure 5-10 through Figure 5-12 for the most recent lateral scans, which the locations correlate well with the historical data. 
RPP-RPT-54912, Rev. 0

Figure 5-9. Tank A-105 Historical Lateral Surveys (counts per second) (RPP-RPT-27605, Rev. 0)

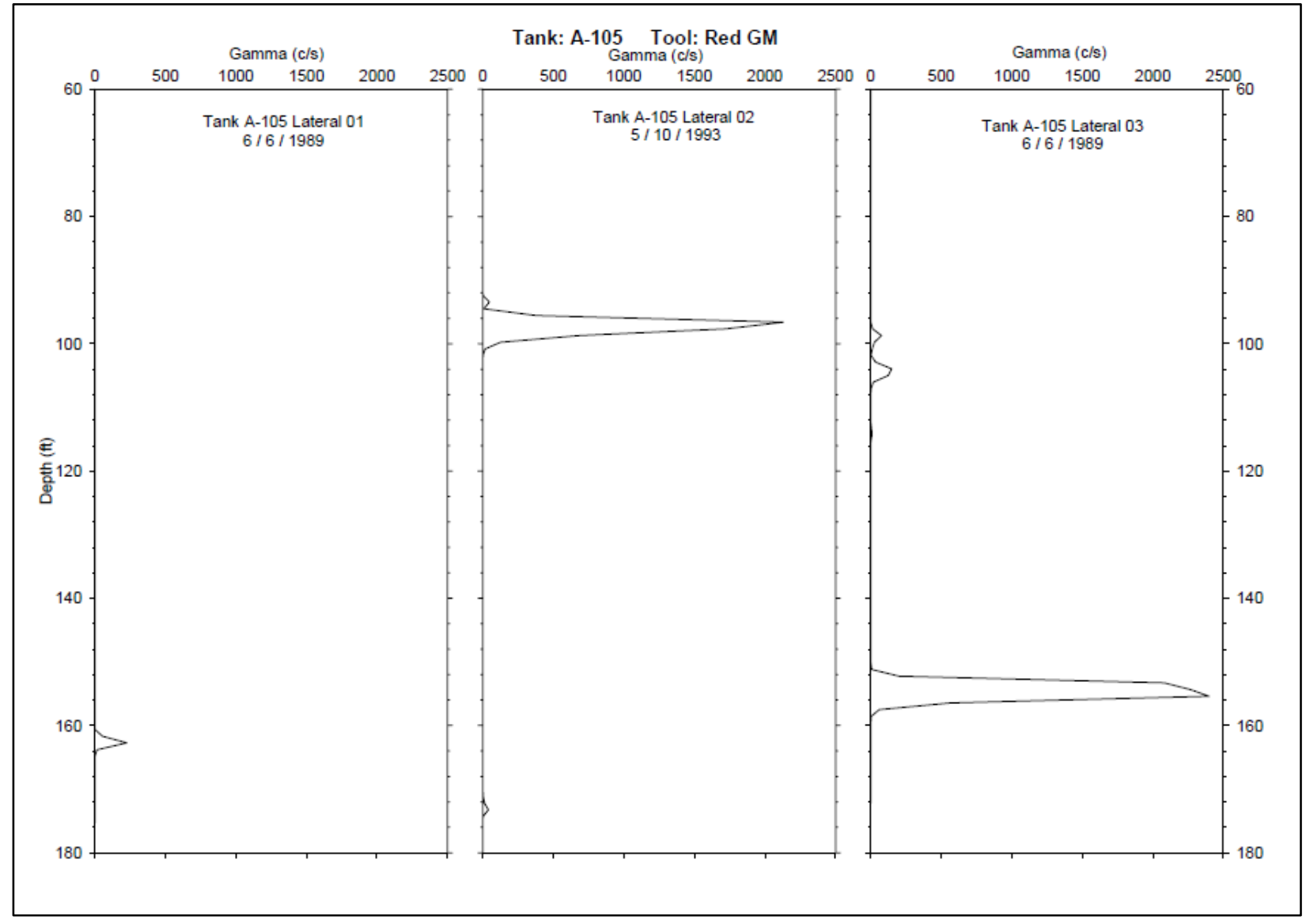


RPP-RPT-54912, Rev. 0

Figure 5-10. Summary Gamma Survey for Lateral 14-05-01 on Logarithmic Scale April 19, 2005

(RPP-RPT-27605, Rev. 0)

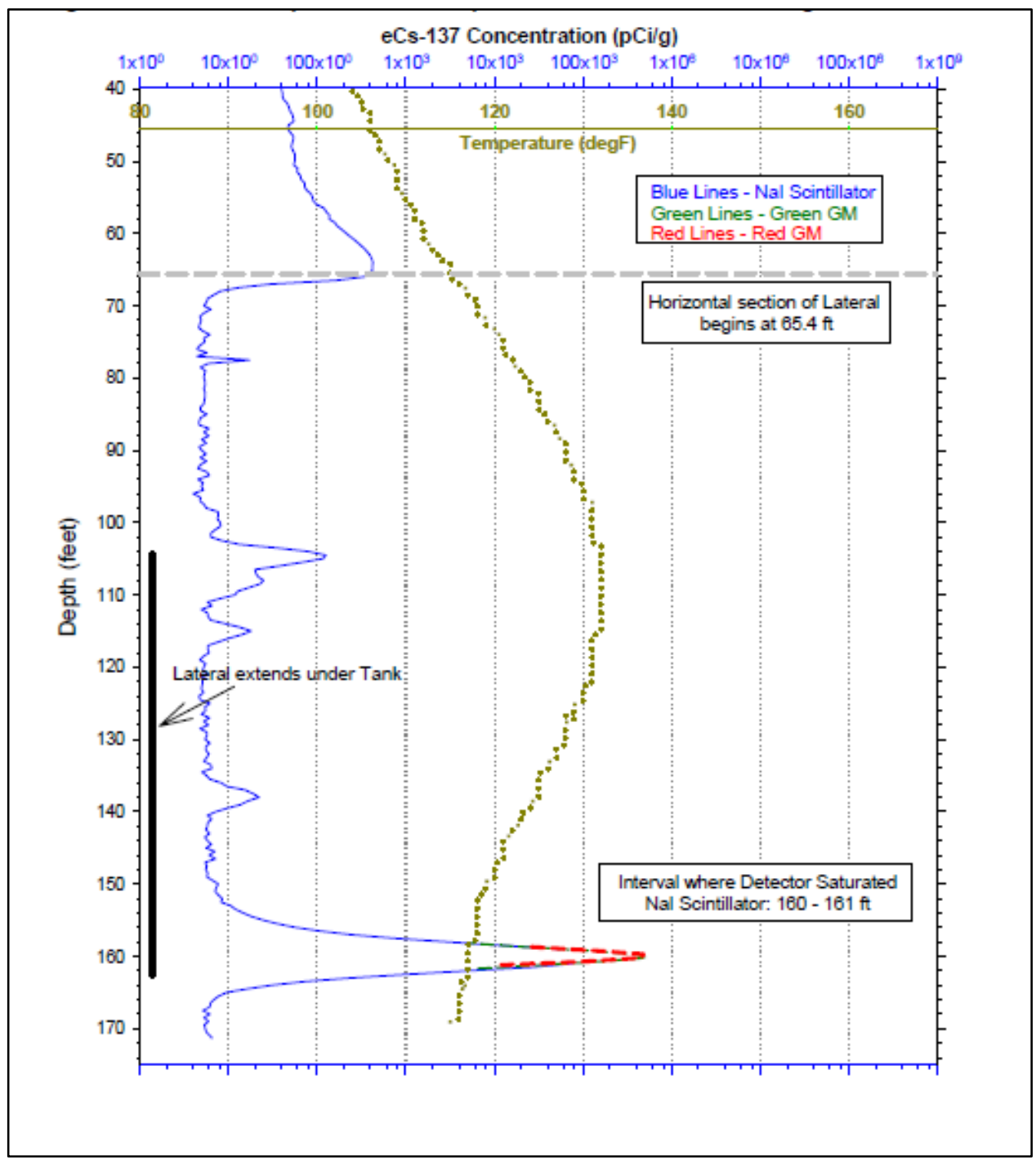


RPP-RPT-54912, Rev. 0

Figure 5-11. Summary Gamma Survey for Lateral 14-05-02 on Logarithmic Scale April 19, 2005

(RPP-RPT-27605, Rev. 0)

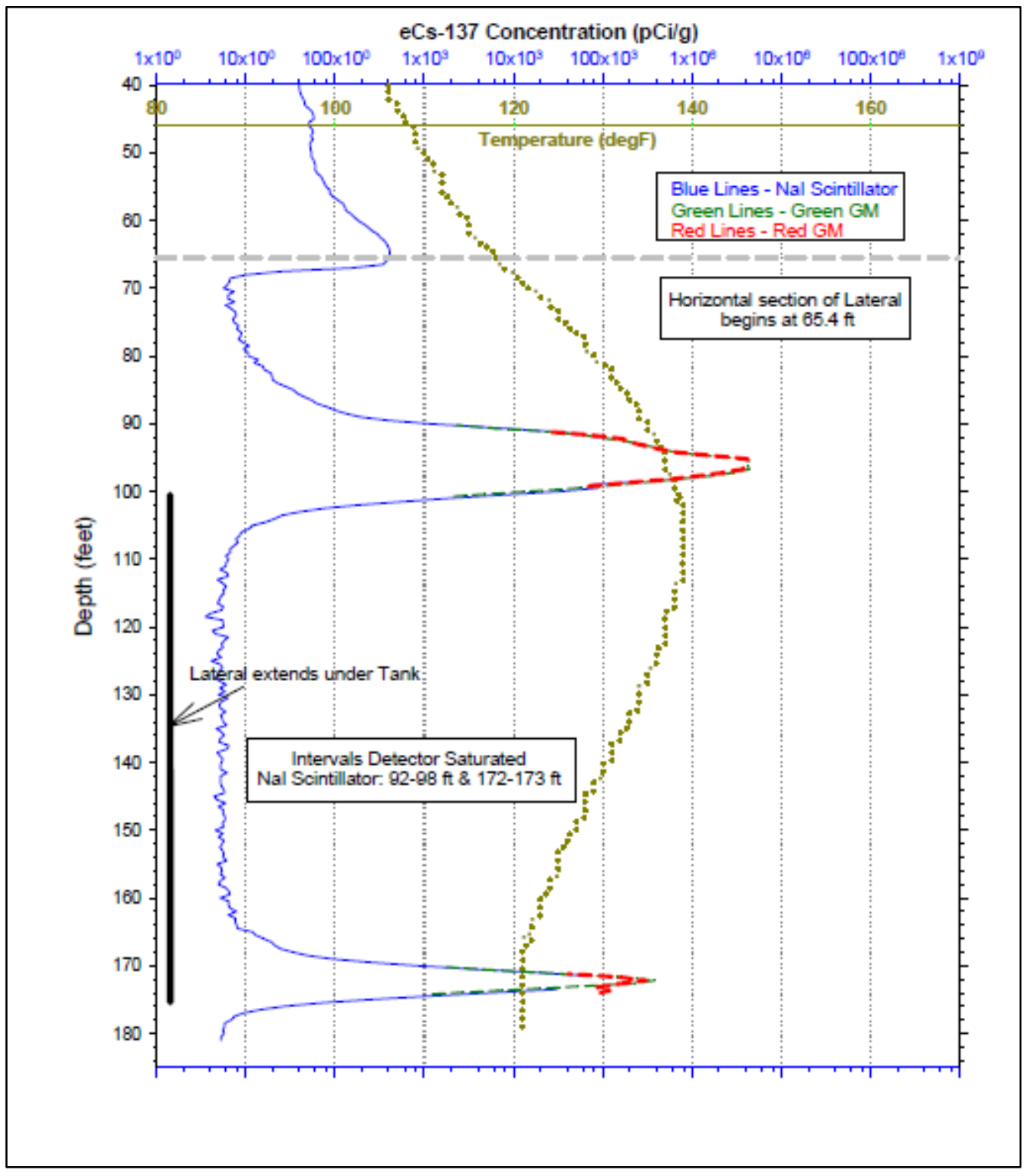


Figure 5-12. Summary Gamma Survey for Lateral 14-05-03 on Logarithmic Scale April 13, 2005

(RPP-RPT-27605, Rev. 0)

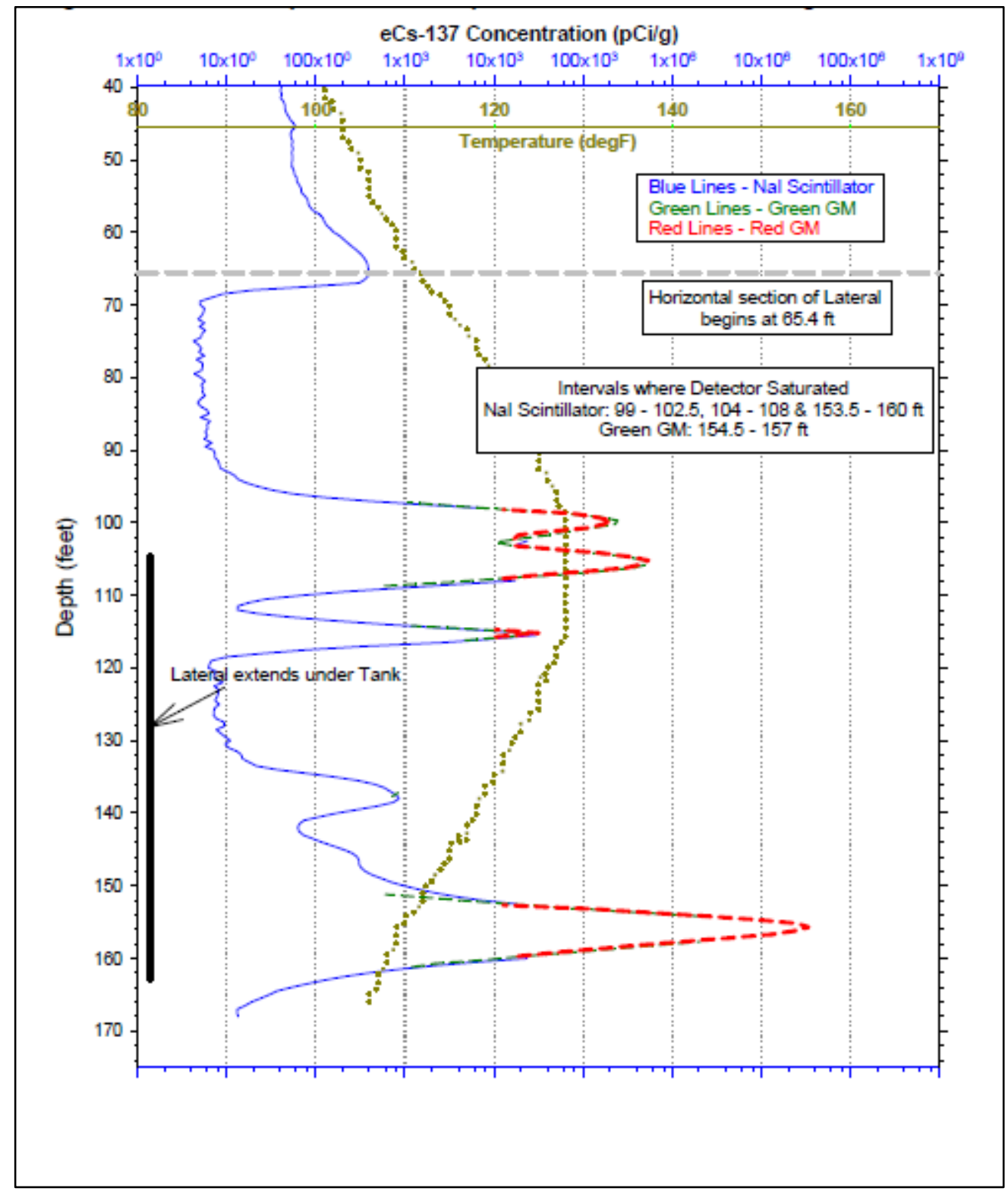

\subsubsection{Drywells}

There are nine drywells located around tank A-105: 10-06-09, 10-05-05, 10-05-07, 10-05-08, 10-04-04, 10-05-09, 10-05-10, and 10-05-12 installed in April 1962 and 10-05-02 installed in May 1962. Three additional test wells were drilled near the end of lateral 14-05-03 in 1965 . No raw data were recovered for these test wells; however, it was reported that no radioactivity or moisture was detected in these test wells (RL-SEP-509). All of the radiation readings in drywells are assumed to be maximum or peak readings unless otherwise noted (see Section 
3.3.2). The following subsections report the available drywell information and the drywell summary section provides the analyses of the associated drywells with tank A-105. The bottom of the tank footing for tank A-105 is approximately 47-ft 10-in BGS.

\subsubsection{Drywell 10-05-02}

Drywell 10-05-02 was drilled in May 1962 with the first recoverable readings on January 7, 1965 with a peak of $40 \mathrm{~K}$ cpm at $74-\mathrm{ft}$ BGS. Radioactivity levels at this depth remained relatively stable from 1965 to 1978 . Radioactivity levels then slowly declined and were reported at $2 \mathrm{~K}$ cpm at 71-ft BGS in November 1986 (see Appendix D2).

By October 1998, Cs-137 was the only man-made radionuclide detected in drywell 10-05-02 with the maximum concentration of $10 \mathrm{pCi} / \mathrm{g}$ detected at 4-ft BGS (GJ-HAN-110). Deeper down in the drywell, Cs-137 concentration was reported as less than $1 \mathrm{pCi} / \mathrm{g}$. Document GJ-HAN-110 reports, "The source of anomalous activity in the historical gross gamma-ray logs from 1975 to 1978 is questionable. The contaminants in this depth range may have accumulated and concentrated on the outside or inside of the casing near the original bottom of the borehole. It is possible that this concentrated material was detected by the gross gamma-ray device, but the residual contaminants in the formation were at too low a concentration to be detectable." Since Cs-137 levels were reported to be small in drywell 10-05-02, it is likely the historical radioactivity detected was short-lived, such as RuRh-106 (see Figure 5-14). The source of radioactivity detected in this drywell may have been migration of mobile RuRh-106 from a tank A-105 leak. Figure 5-13 shows the depths of radioactivity from 1975 to 1995 (RPP-8820). 
RPP-RPT-54912, Rev. 0

Figure 5-13. Tank A-105 Drywell 10-05-02 (RPP-8820)

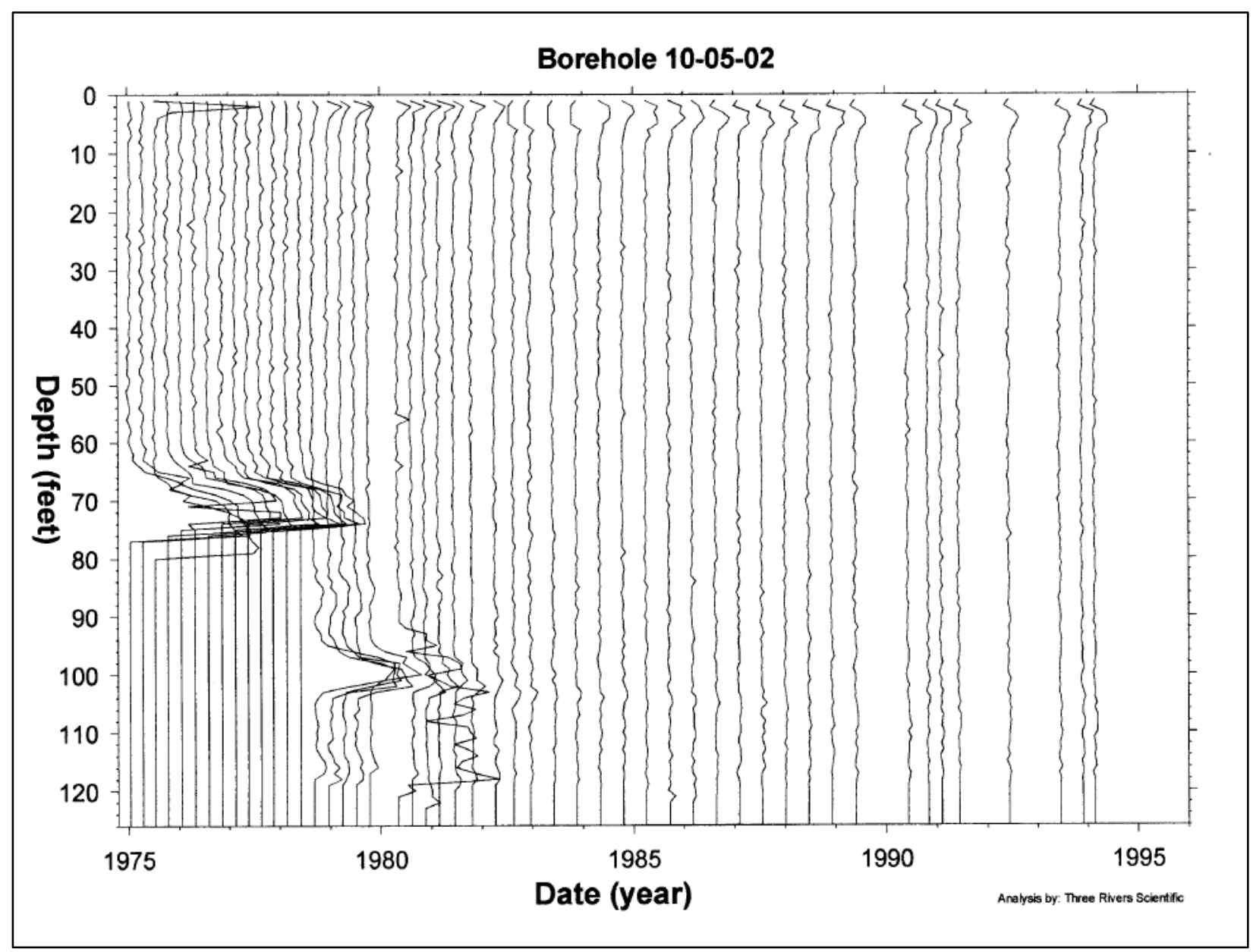

Note: Bottom of the tank footing is $~ 47-\mathrm{ft} 10$-in BGS 
RPP-RPT-54912, Rev. 0

Figure 5-14. Drywell 10-05-02 Ruthenium Decay (RPP-8820)

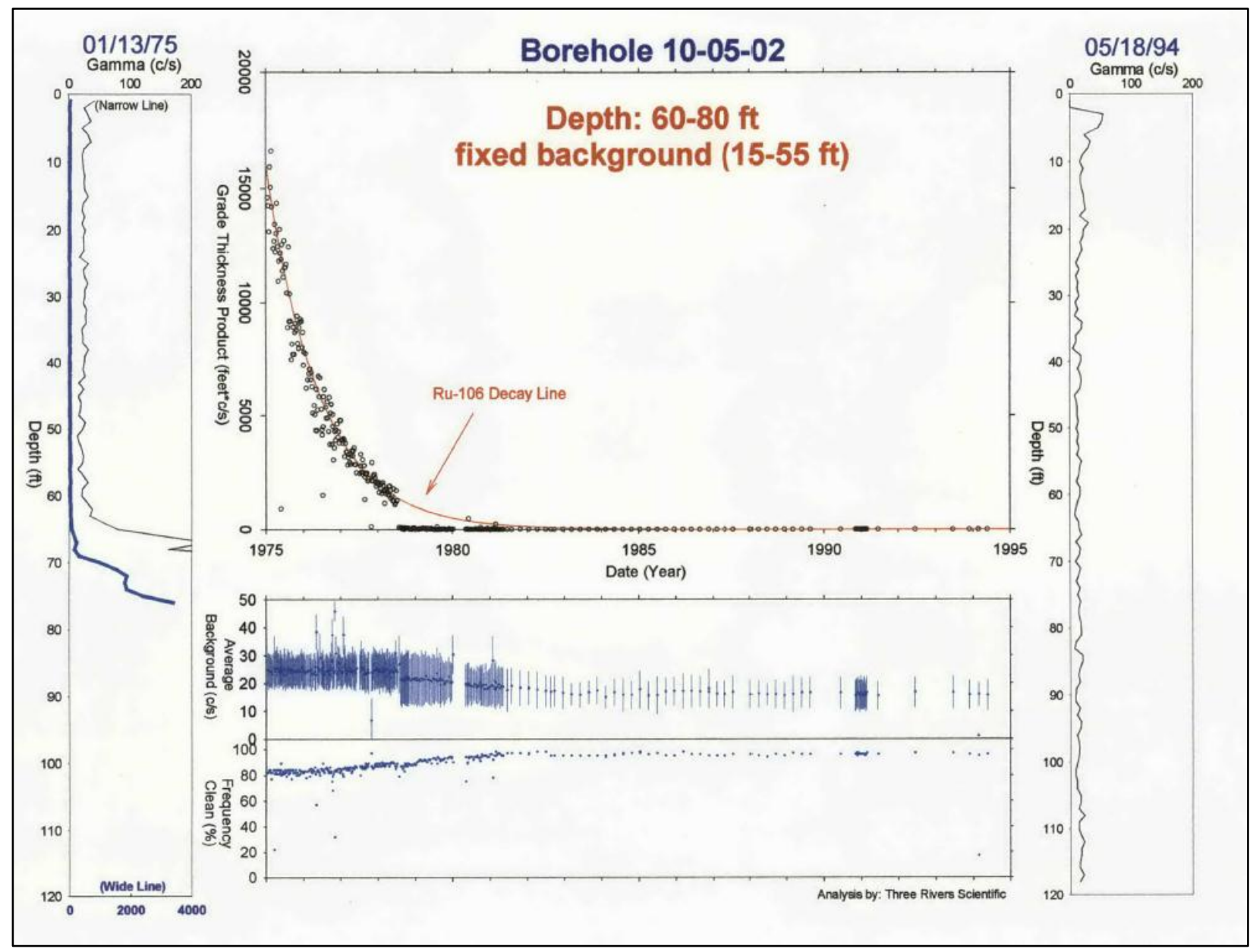

\subsubsection{Drywell 10-06-09}

Drywell 10-06-09 was drilled in April 1962 with the first recoverable readings on January 3, 1965 with two peaks of $45 \mathrm{~K}$ cpm reported at $18-\mathrm{ft}$ and $83-\mathrm{ft}$ BGS. Radioactivity levels remained relatively stable at these two depths through August 1966. The next recoverable reading was on September 13, 1972 and reported as less than values at this time through 1986 (see Appendix D2).

In October 1998, Cs-137 was the only man-made radionuclide detected in drywell 10-06-09 (GJHAN-110). From the ground surface to $15-\mathrm{ft}$ BGS, Cs-137 was detected continuously at concentrations ranging from 5 to $20 \mathrm{pCi} / \mathrm{g}$. Document GJ-HAN-110 reports, "The Cs-137 contamination detected between the ground surface and $20 \mathrm{ft}$ probably resulted from the borehole extension activities. The contamination in this interval was first recognized after completion of the borehole extension and was most likely placed around the borehole when the temporary 8-in starter casing was installed." Therefore, drywell 10-06-09 is not included as part of the leak location for tank A-105. Figure 5-15 shows the depths of radioactivity from 1975 to 1995 (RPP-8820). 
RPP-RPT-54912, Rev. 0

Figure 5-15. Tank A-105 Drywell 10-06-09 (RPP-8820)

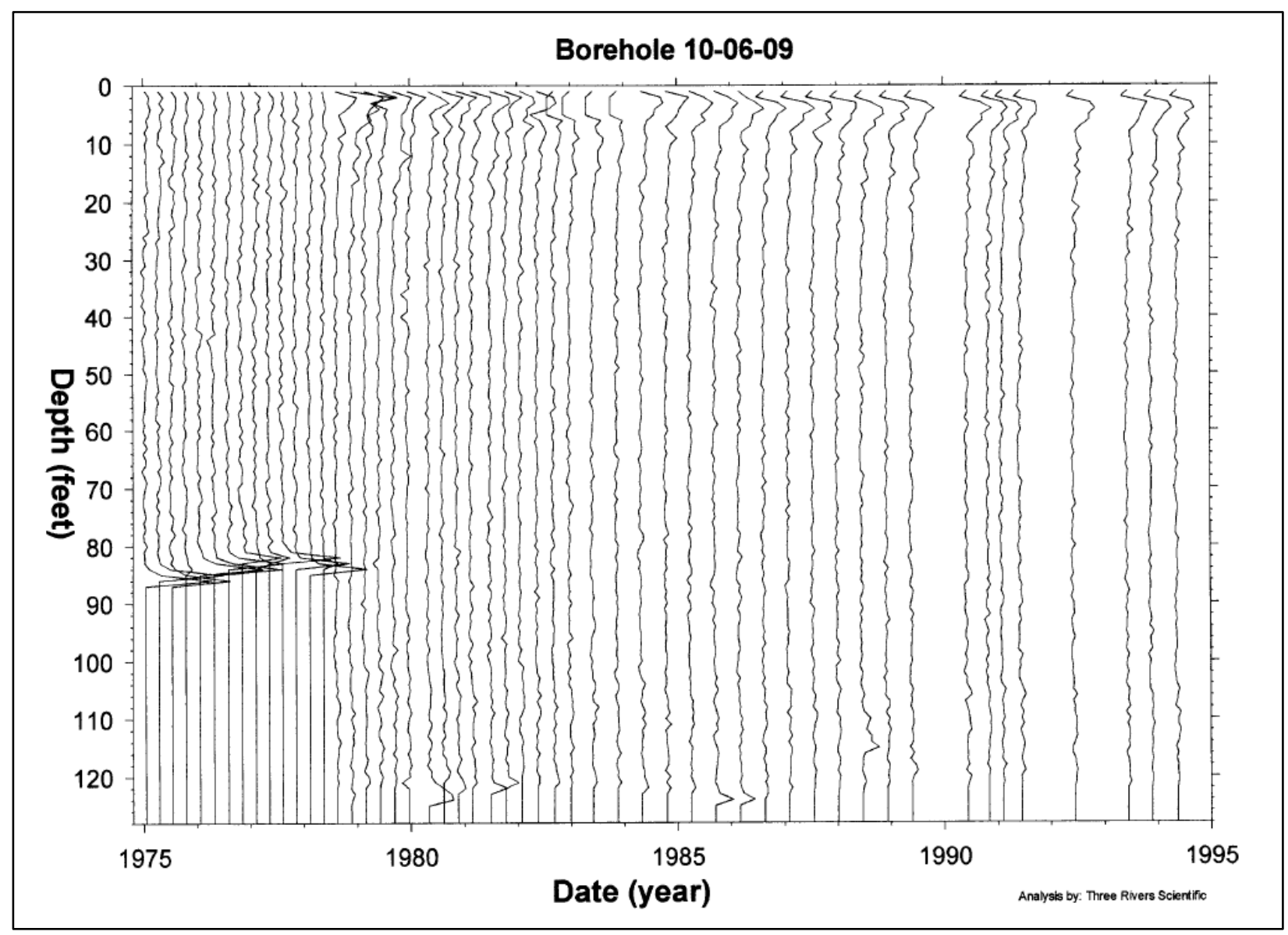

Note: Bottom of the tank footing is $~ 47-\mathrm{ft} 10$-in BGS 


\subsubsection{Drywell 10-05-05}

Drywell 10-05-05 was drilled in April 1962 with the first recoverable reading on January 3, 1965 with a peak reading of $56 \mathrm{~K} \mathrm{cpm}$ at $75-\mathrm{ft}$ BGS (see Appendix D2). Radiation levels remained relatively stable at this depth through August 1966. The next recoverable reading was on September 13, 1972 and reported as less than values at this time through 1986.

In October 1998, Cs-137 was detected nearly continuously from the ground surface to 74.5 -ft BGS (GJ-HAN-110). From 6-ft to 55-ft BGS, Cs-137 concentrations were about $1 \mathrm{pCi} / \mathrm{g}$ or less and between 1 and $3 \mathrm{pCi} / \mathrm{g}$ at depths below 55-ft BGS. Document GJ-HAN-110 reports, "Shape factor results for the rest of the borehole have been interpreted to indicate a contaminant distribution that is local to the borehole casing, indicating that the contamination was probably carried down from the contaminated interval near the top of the borehole during the drilling operation." Therefore, drywell 10-05-05 is not included as part of the leak location for tank A105. Figure 5-16 shows the depths of radioactivity from 1975 to 1995 (RPP-8820).

Figure 5-16. Tank A-105 Drywell 10-05-05 (RPP-8820)

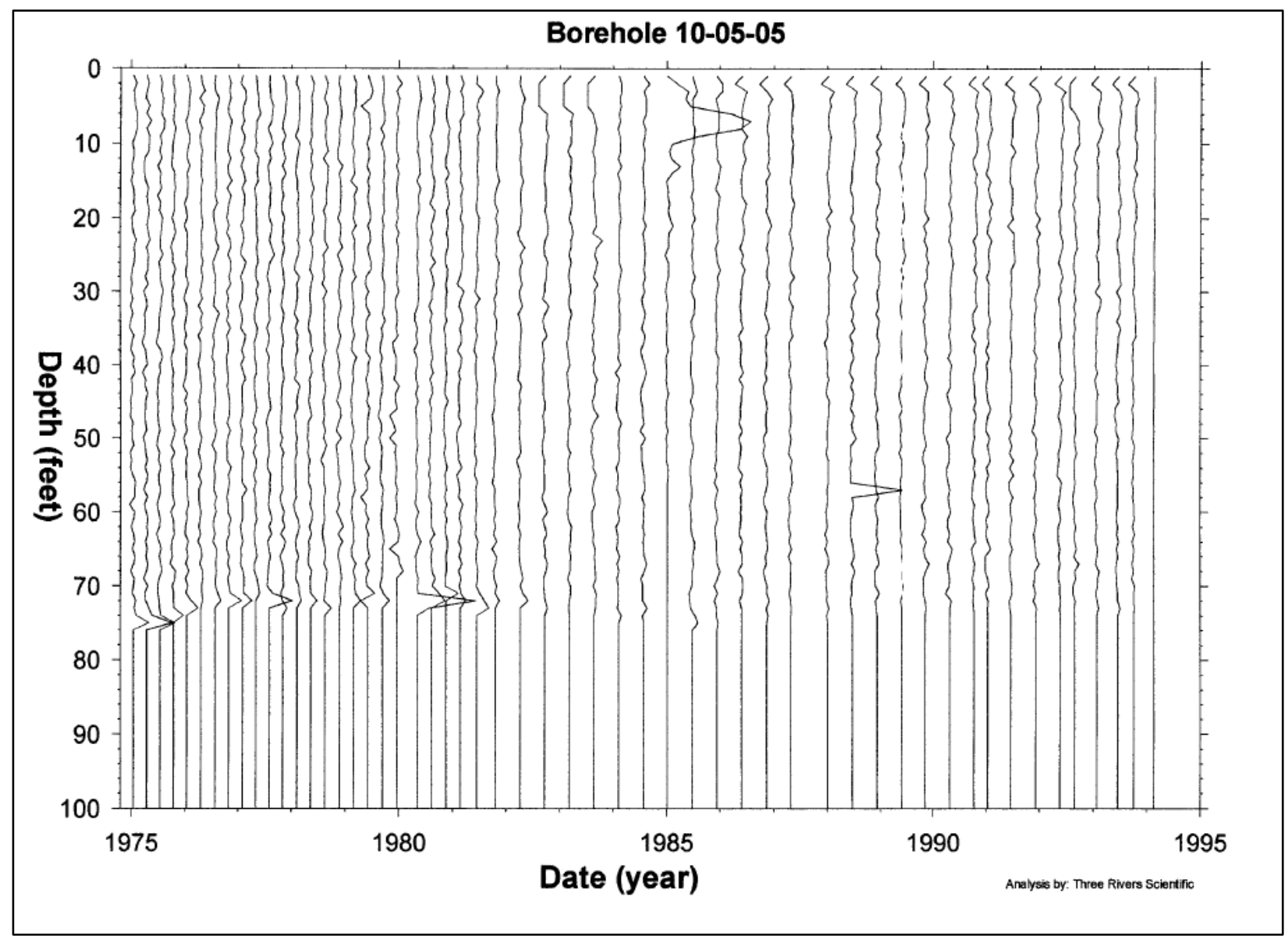

Note: Bottom of the tank footing is $~ 47-\mathrm{ft} 10$-in BGS 


\subsubsection{Drywell 10-05-07}

Drywell 10-05-07 was drilled in April 1962 with the first recoverable reading on January 7, 1965 with a peak reading of $21 \mathrm{~K} \mathrm{cpm}$ at $74-\mathrm{ft}$ BGS (see Appendix D2). Radiation levels were roughly the same through August 1966. The next recoverable reading was on September 13, 1972 and reported as less than values at this time through 1986.

In October 1998, Cs-137 was the only man-made radionuclide detected in drywell 10-05-07 (GJHAN-110). From 6-ft to 32-ft BGS, Cs-137 concentrations were recorded intermittently at concentrations between $0.15 \mathrm{pCi} / \mathrm{g}$ (just above the minimum detection limit) to about $1 \mathrm{pCi} / \mathrm{g}$. From 32-ft to 57-ft BGS, Cs-137 was also noted sporadically at concentrations just above the minimum detection limit and from 57 to 75.5 -ft BGS at concentrations between $0.3 \mathrm{pCi} / \mathrm{g}$ to about $1 \mathrm{pCi} / \mathrm{g}$. Document GJ-HAN-110 reports that the Cs-137 concentration detected in this drywell was likely caused by dragdown from a surface spill. Therefore, drywell 10-05-07 is not included as part of the leak location for tank A-105. Figure 5-17 shows the depths of radioactivity from 1975 to 1995 (RPP-8820).

Figure 5-17. Tank A-105 Drywell 10-05-07 (RPP-8820)

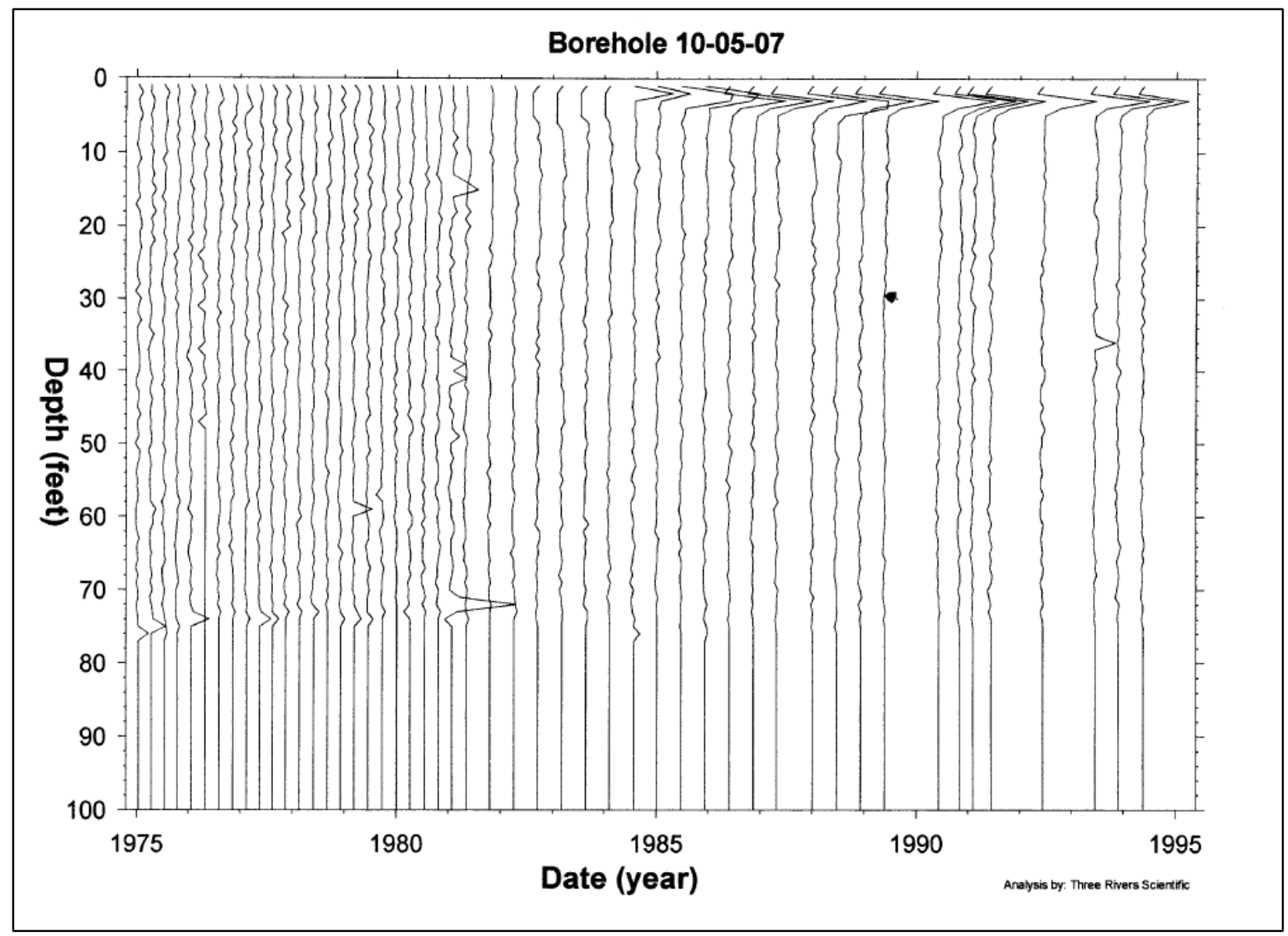

Note: Bottom of the tank footing is $\sim 47-\mathrm{ft} 10$-in BGS 


\subsubsection{Drywell 10-05-08}

Drywell 10-05-08 was drilled in April 1962 with the first recoverable reading on September 13, 1972. Radiation levels were reported as less than values from 1972 through 1986 (see Appendix D2).

In October 1998, Cs-137 was the only man-made radionuclide detected in drywell 10-05-08 (GJHAN-110). From the ground surface to $21-\mathrm{ft}$ BGS, Cs-137 concentrations were detected at concentrations less than $1 \mathrm{pCi} / \mathrm{g}$ below a depth of $15-\mathrm{ft}$. At 3.5-ft BGS, a Cs-137 peak was recorded at approximately $25 \mathrm{pCi} / \mathrm{g}$, at 7.5 -ft BGS at about $130 \mathrm{pCi} / \mathrm{g}$, and at 13.5-ft BGS at 6 $\mathrm{pCi} / \mathrm{g}$. Document GJ-HAN-110 reports, "The Cs-137 contamination detected between the ground surface and $15 \mathrm{ft}$ probably resulted from a surface spill or a leak from a near-surface pipeline that migrated down into the shallow backfill surrounding the borehole." Therefore, drywell 10-05-08 is not included as part of the leak location for tank A-105. Figure 5-18 shows the depths of radioactivity from 1975 to 1995 (RPP-8820).

Figure 5-18. Tank A-105 Drywell 10-05-08 (RPP-8820)

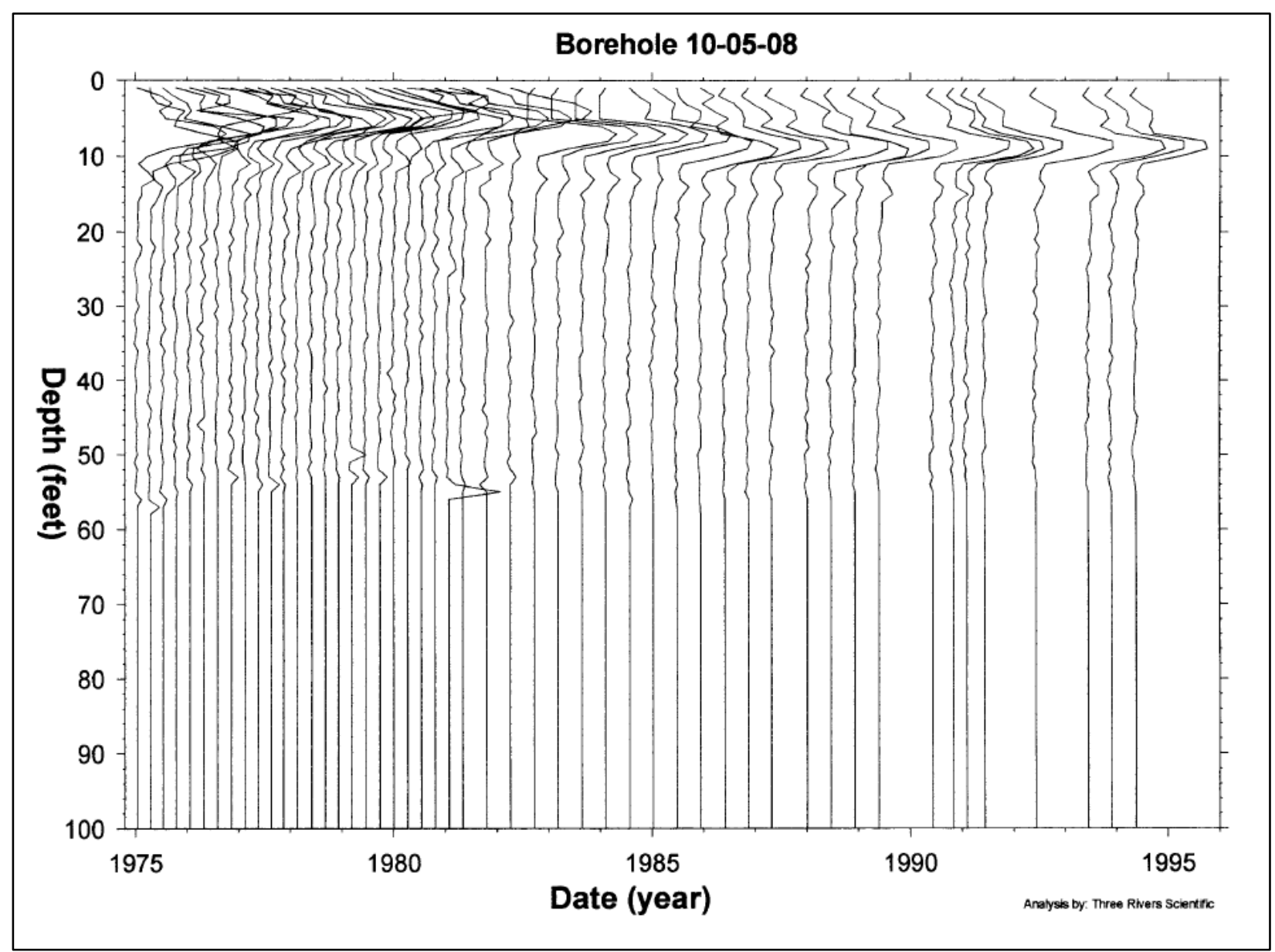

Note: Bottom of the tank footing is $\sim 47-\mathrm{ft} 10$-in BGS 


\subsubsection{Drywell 10-04-04}

Drywell 10-04-04 was drilled in May 1955 with the first recoverable reading on September 13, 1972. Radiation levels were reported as less than values from 1972 through 1986 (see Appendix D2).

In October 1998, Cs-137 and Eu-154 were the only man-made radionuclides detected in drywell 10-04-04 (GJ-HAN-110). From the ground surface to 6.5-ft BGS and at the bottom of the drywell, Cs-137 was detected continuously. The maximum Cs-137 concentration was $20 \mathrm{pCi} / \mathrm{g}$ at about 1-ft BGS and concentrations decreased to $2 \mathrm{pCi} / \mathrm{g}$ or less below this depth. Eu-154 contamination was detected from 4.5 to $6.5-\mathrm{ft} \mathrm{BGS}$ at concentrations less than $1 \mathrm{pCi} / \mathrm{g}$. Document GJ-HAN-110 reports, "The man-made contaminants detected from the ground surface to $6.5 \mathrm{ft}$ probably resulted from a surface spill that migrated into the backfill surrounding the borehole. The shape factor analysis suggests that some of the contamination occurs as a linear source, such as a pipeline." Therefore, drywell 10-04-04 is not included as part of the leak location for tank A-105. Figure 5-19 shows the depths of radioactivity from 1975 to 1995 (RPP8820).

Figure 5-19. Tank A-105 Drywell 10-04-04 (RPP-8820)

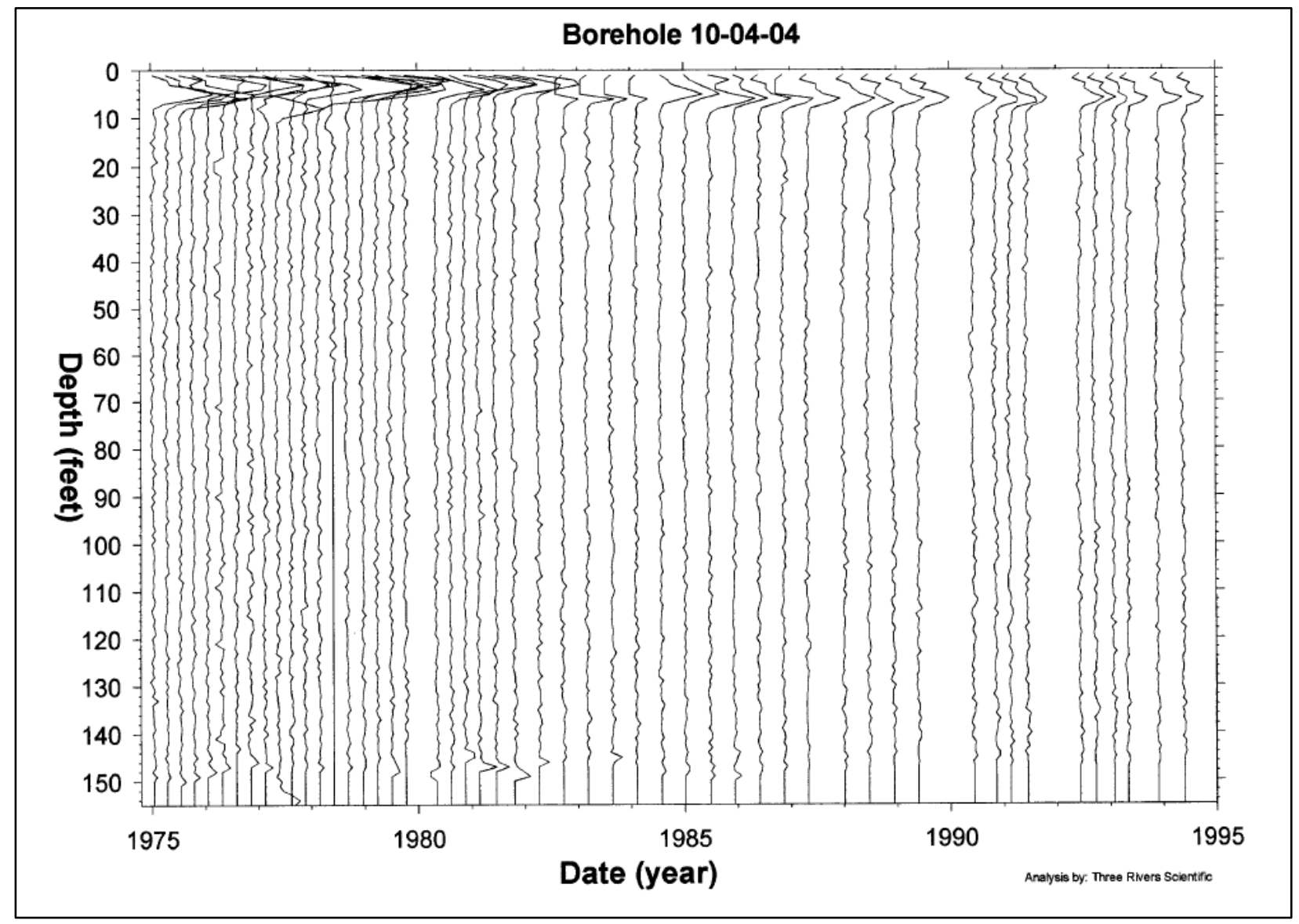

Note: Bottom of the tank footing is $\sim 47$-ft 10-in BGS 


\subsubsection{Drywell 10-05-09}

Drywell 10-05-09 was drilled in April 1962 with the first recoverable reading on January 7, 1965 with a peak reading of $15 \mathrm{~K} \mathrm{cpm}$ at $15-\mathrm{ft}$ BGS (see Appendix D2). Radioactivity at this BGS level appeared to have been short-lived as these readings in 1966 decayed to less than values in 1972. The next recoverable reading was on September 13, 1972 and reported as less than values at this time through 1986.

In October 1998, Cs-137 was the only man-made radionuclide detected in drywell 10-05-09 (GJHAN-110). From the ground surface to $15-\mathrm{ft}$ BGS, Cs-137 contamination was detected nearly continuously at concentrations ranging from $0.3 \mathrm{pCi} / \mathrm{g}$ to about $90 \mathrm{pCi} / \mathrm{g}$ at a depth of $1-\mathrm{ft} \mathrm{BGS}$. From 27.5-ft to 47-ft BGS, Cs-137 was also detected intermittently at concentrations just above the minimum detection limit and from 51 to $76.5-\mathrm{ft}$ BGS at concentrations less than $1 \mathrm{pCi} / \mathrm{g}$. Document GJ-HAN-110 reports, "The Cs-137 contamination detected from the ground surface to a depth of $10 \mathrm{ft}$ probably resulted from a surface spill that migrated into the backfill sediment around the borehole. The contamination from 10 to $50 \mathrm{ft}$ was probably carried downward from the ground surface during the drilling operation. The Cs-137 concentrations below $50 \mathrm{ft}$ were too low to support shape factor analysis. Attempts to link this contamination to a source are speculative, but the contamination may be correlatable with contamination at this depth interval in borehole 10-05-10."

Therefore, drywell 10-05-09 is not included as part of the leak location for tank A-105. Figure 5-20 shows the depths of radioactivity from 1975 to 1995 (RPP-8820).

Figure 5-20. Tank A-105 Drywell 10-05-09 (RPP-8820)

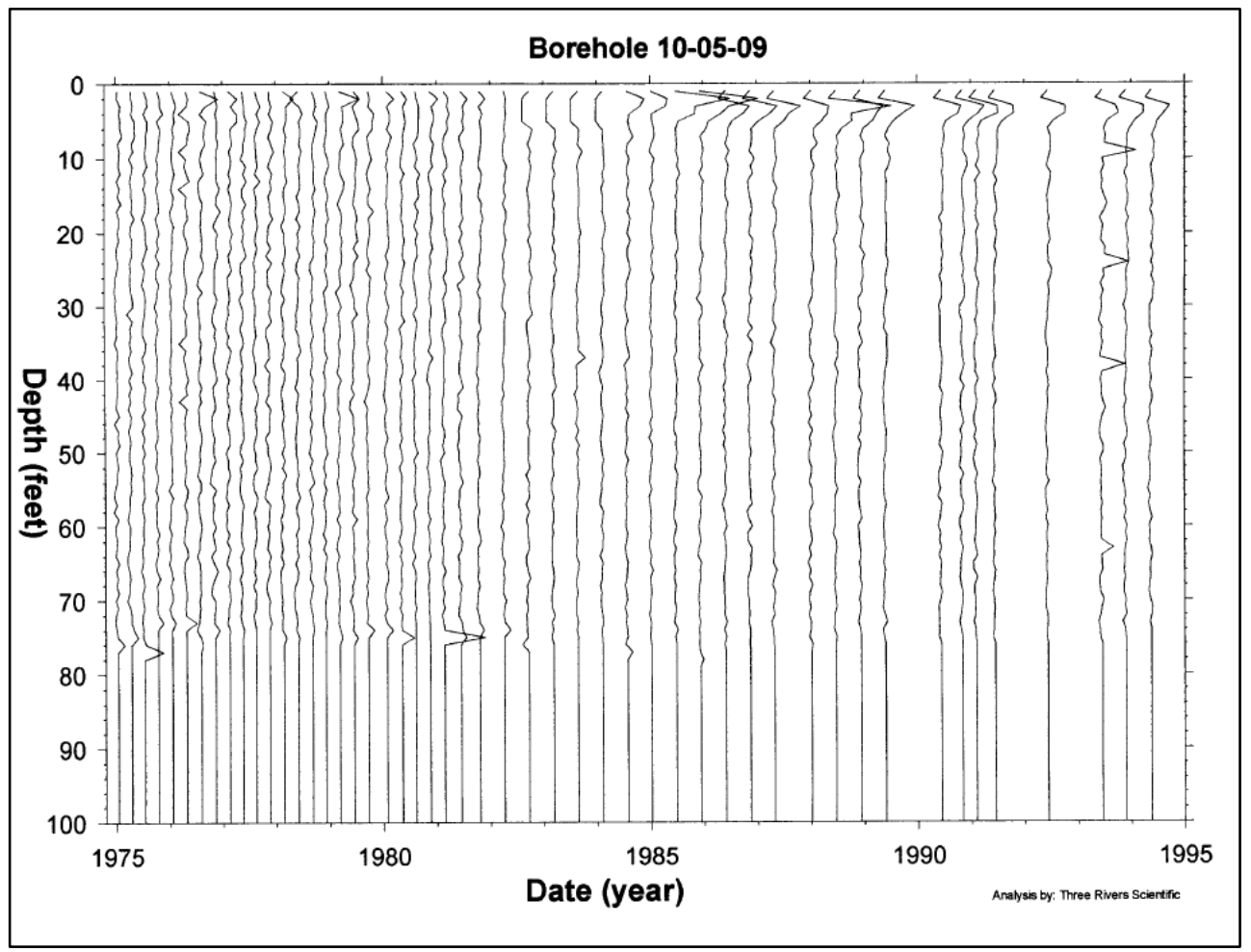

Note: Bottom of the tank footing is $\sim 47$-ft 10 -in BGS 


\subsubsection{Drywell 10-05-10}

Drywell 10-05-10 was drilled in April 1962 with the first recoverable reading on January 7, 1965 with three peak readings recorded at 50-ft, 70-ft, and 74-ft BGS with the maximum reading of 8K cpm at 74-ft BGS (see Appendix D2). Radiation levels were relatively stable through August 1966. The next recoverable reading was on September 13, 1972 with a peak reading of $28 \mathrm{~K} \mathrm{cpm}$ at 60-ft BGS. Radiation levels gradually declined at this BGS depth and were reported as less than values in November 1977. The next data point taken August 18, 1978 reports a peak of 8K cpm at 74-ft BGS and this peak remained stable through November 1986 at this lower depth.

In October 1998, Cs-137 concentrations were detected continuously in three distinct zones from the ground surface to 89.5 -ft BGS at concentrations ranging from 20 to $30 \mathrm{pCi} / \mathrm{g}$ or higher (GJHAN-110). The zones extend from the ground surface to about 17-ft BGS, from 25 to $55-\mathrm{ft}$ BGS, and about 78 to $85-\mathrm{ft}$ BGS.

Document GJ-HAN-110 reports, "The zones of anomalous gamma-ray activity indicated on the historical gross gamma logs and the Cs-137 contamination detected by the SGLS from 58 to 64 $\mathrm{ft}$ and 76 to $86 \mathrm{ft}$ appear to correlate with activity detected in lateral 14-05-02 at $170 \mathrm{ft}$. The lateral logs for this borehole indicate the presence of a fairly long-lived contaminant at this location. It appears that a plume from a leak near the northwest side of tank A-105 intercepted borehole 10-05-10 from 58 to $64 \mathrm{ft}$ and 76 to $86 \mathrm{ft}$ and lateral 14-05-02 at $170 \mathrm{ft}$. However, the mechanism by which the contamination arrived at these locations is not clearly understood." However, with the quantity of water and supernatant used for cooling and leaching tank A-105 waste that some leakage occurred that provided a transport mechanism for some of the radionuclides. Figure 5-21 shows the depths of radioactivity from 1975 to 1995 (RPP-8820).

Figure 5-21. Tank A-105 Drywell 10-05-10 (RPP-8820)

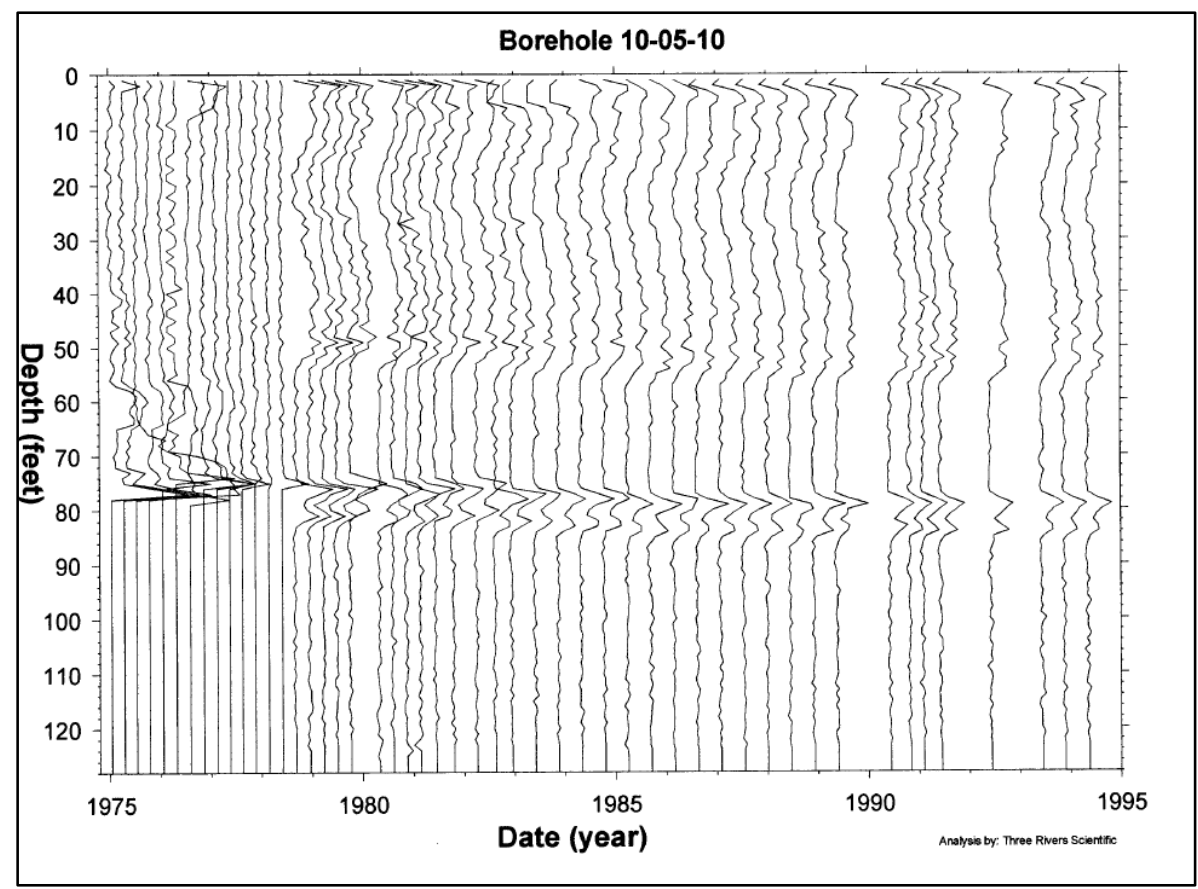

Note: Bottom of the tank footing is $~ 47$-ft 10 -in BGS 


\subsubsection{Drywell 10-05-12}

Drywell 10-05-12 was drilled in April 1962 with the first recoverable reading on January 3, 1965 with four peak readings recorded at $5-\mathrm{ft}, 50-\mathrm{ft}, 70-\mathrm{ft}$, and $75-\mathrm{ft}$ BGS with the maximum value of $110 \mathrm{~K}$ cpm recorded at 75-ft BGS (see Appendix D2). Radiation levels remained relatively stable at these four peaks through August 1966. The next recoverable reading was on September 13, 1972 with a peak reading of $9 \mathrm{~K}$ cpm reported at 76-ft BGS. The next data was recorded April 10, 1974 and radioactivity was reported as less than values at this time through November 1986.

In October 1998, Cs-137 concentrations were detected nearly continuously from the ground surface to 75.5-ft BGS (GJ-HAN-110). The measured Cs-137 concentrations ranged from 0.5 to $30 \mathrm{pCi} / \mathrm{g}$ at 7-ft BGS to approximately $300 \mathrm{pCi} / \mathrm{g}$ at 1.5-ft BGS. At depths between 10 and 50-ft BGS, Cs-137 concentrations were about $1 \mathrm{pCi} / \mathrm{g}$ or less. Between depths of 50 and $60-\mathrm{ft} \mathrm{BGS}$, Cs-137 concentrations increase to between 1 and 2 pCi/g. At depths below 60-ft BGS, Cs-137 concentrations increase to about 3 to $5 \mathrm{pCi} / \mathrm{g}$.

Document GJ-HAN-110 reports, "It is most likely that the contamination in the entire interval from $13 \mathrm{ft}$ to the bottom of the borehole is restricted to the borehole casing, and was probably carried downward from the near-surface contaminated zone during the drilling operation." Document GJ-HAN-110 also stated that radioactivity reported from the ground surface to 13-ft BGS likely resulted from surface spills that have migrated into the backfill sediments. Therefore, drywell 10-05-12 is not included as part of the leak location for tank A-105. Figure 5-22 shows the depths of radioactivity from 1975 to 1995 (RPP-8820).

Figure 5-22. Tank A-105 Drywell 10-05-12 (RPP-8820)

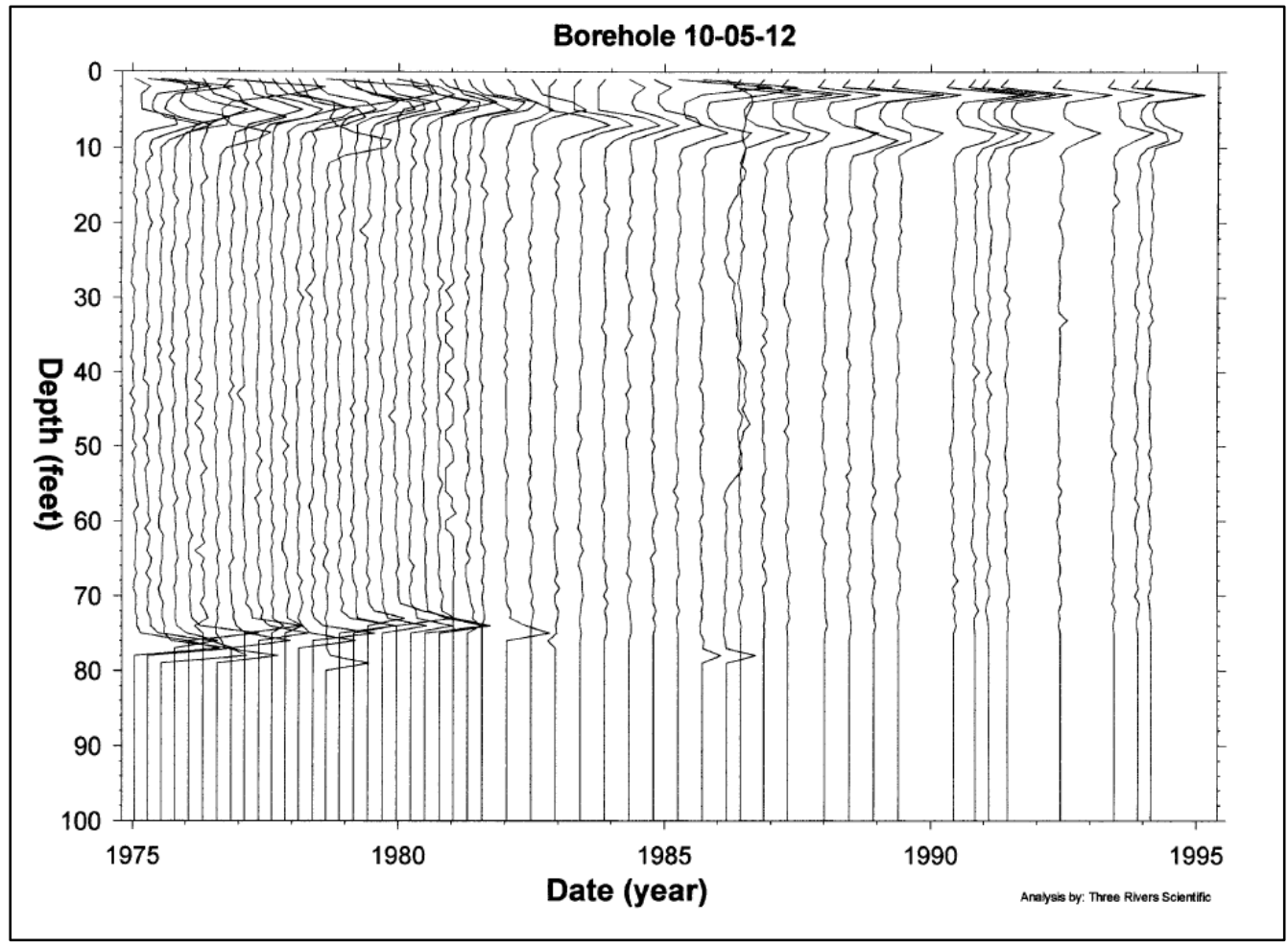

Note: Bottom of the tank footing is $\sim 47$-ft 10-in BGS 


\subsubsection{Drywell Summary}

Tank A-105 was first suspected of leaking in November 1963 due to radioactivity being detected in lateral 14-05-03 in the southeast portion of tank A-105 (see Section 5.5.1). During this time, no drywells were reported to have increased radioactivity levels.

Tank A-105 drywells 10-06-09, 10-05-05, 10-05-07, 10-05-08, 10-04-04, 10-05-09, and 10-0512 do not indicate any radioactivity associated with a tank A-105 leak. Therefore, these drywells are not included in the leak location for tank A-105.

Radioactivity in drywell 10-05-02 first appeared before January 7, 1965 at 74-ft BGS which was before the steam eruption on January 28, 1965 in tank A-105. It appears the source of radioactivity detected in drywell 10-05-02 was mobile RuRh-106 that may have migrated from tank A-105, possibly from the leak detected in lateral 14-05-03 in November 1963 in the southeastern portion of the tank. However, there was no indication of radioactivity in nearby drywell 10-06-09 and the radioactivity could have been from another source.

Drywell 10-05-10 first reported low-level radioactivity before January 7, 1965 with three peak readings recorded at 50-ft, 70-ft, and 74-ft BGS and remained relatively stable through August 1966. The next recoverable reading was in September 1972 with a peak reading at $60-\mathrm{ft}$ BGS at higher radiation readings. It is likely radioactivity detected in drywell 10-05-10 is associated with radioactivity detected in lateral 14-05-02 in 1968 (see Section 5.5.1).

Three test wells were drilled near the end of lateral 14-05-03 to a depth of about $65-\mathrm{ft}$, or 10-ft below the tank bottom (see Figure 5-23) which did not indicate any localized contamination.

\subsection{POSSIBLE TANK A-105 LINER LEAK LOCATION(S)}

The lateral radioactivity when first detected is an indication of waste leakage from the concrete shell of the tank and could be an indication of the location of liner leak. However, the liner leak may have penetrated the waterproof membrane at a different location or pooled on the waterproof membrane and followed concrete cracks or breaks to a different location including the top of the tank footing.

It is likely that the majority of the tank A-105 leak occurred at the tank footing because all of the indicators, three laterals and one drywell, were located under or adjacent to the tank footing. A sidewall leak was initially suspected in November 1963 when radioactivity was detected in lateral 14-05-03, however subsequent liquid levels at the suspected leak zone did not indicate further leakage. 


\subsubsection{Leak Detected in November 1963}

Tank A-105 was first suspected of leaking in November 1963 due to radioactivity being detected in lateral 14-05-03 in the southeast portion of the tank (see site A in Figure 5-23). It was postulated that a sidewall leak occurred during this time as the waste liquid level increased from 260-in to 280-in four months earlier. After the liquid level was reduced to 260 -in, radiation readings in the lateral slowly decreased leading to the conclusion that a sidewall leak was minor and had self-healed. However, a sidewall leak was never confirmed. No radioactivity was detected in the other laterals or drywells, and tank A-105 remained in service.

Figure 5-23. Tank A-105 Possible Leak Location (November 1963)

Tank inner ring is steel liner; outer ring is outer edge of tank footing

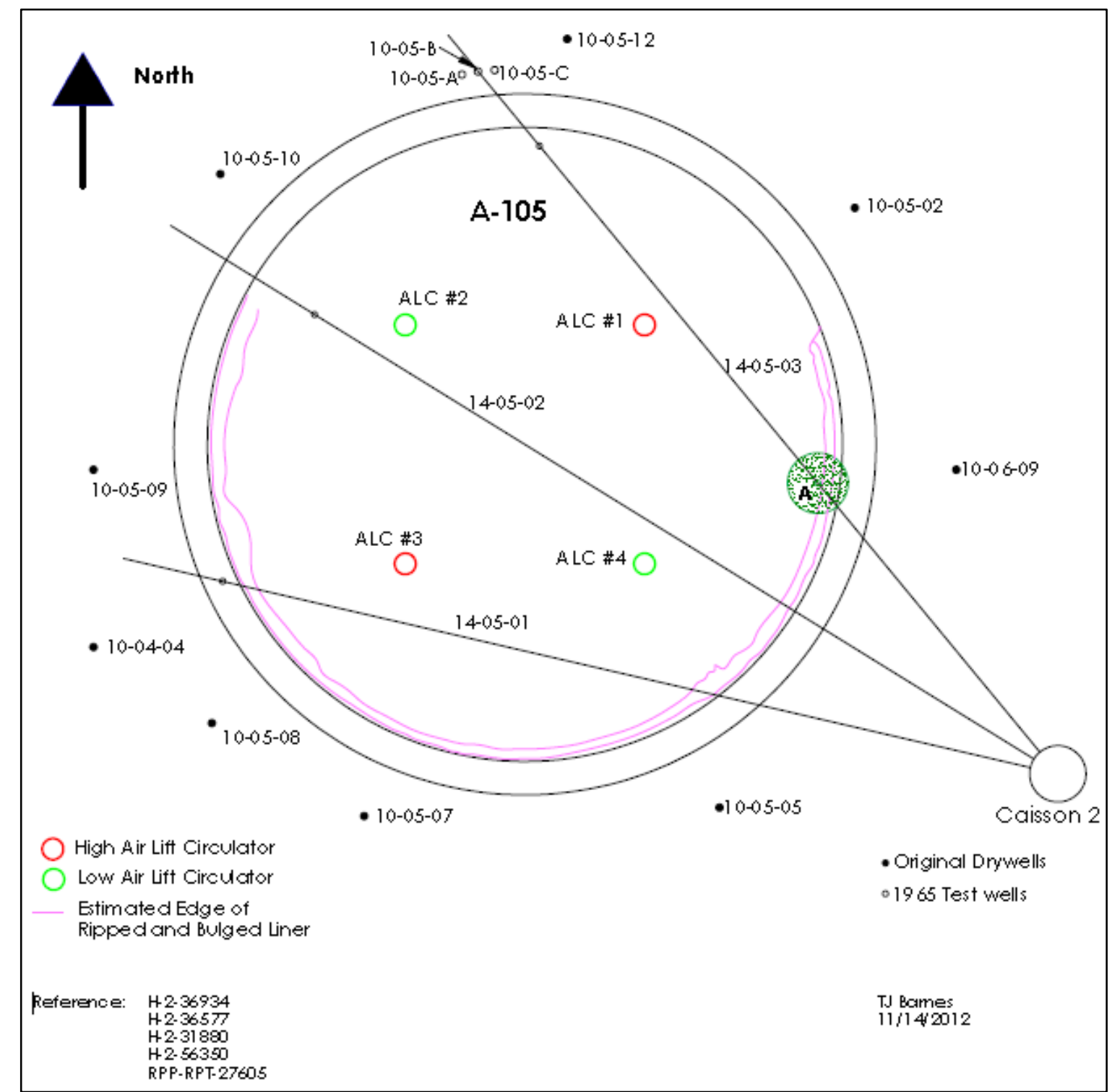

Tank A-105 was first suspected of leaking in November 1963 due to radioactivity being detected in lateral 14-05-03 near the southeast portion of the tank. 


\subsubsection{Leak Detected in 1965}

On January 28, 1965, a steam eruption occurred in tank A-105 causing the bottom liner to tear approximately $3 / 4$ around the perimeter of the tank. One month later, radioactivity was detected in lateral 14-05-03 in the north portion of the tank (see Figure 5-24). Three test wells were drilled near this lateral; however, no radioactivity or moisture was detected in these test wells.

In January 1965, radioactivity was reported in drywell 10-05-02 at 74-ft BGS. The source of this radioactivity may have been migration of mobile RuRh-106 from a tank A-105 leak, possibly related to the November 1963 event (see Figure 5-23).

Figure 5-24. Tank A-105 Leak Indication (1965)

Tank inner ring is steel liner; outer ring is outer edge of tank footing

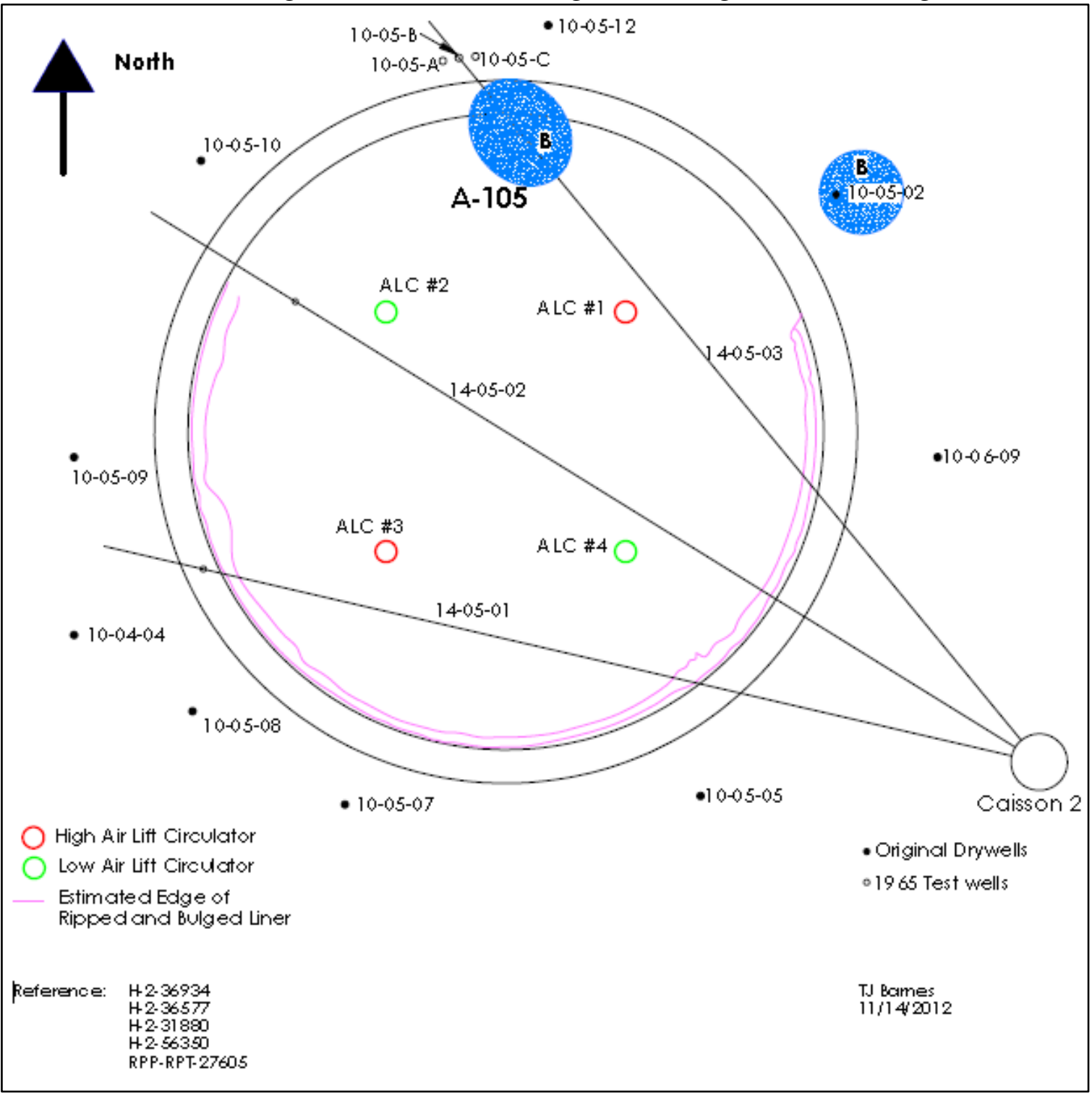

Tank A-105 was first suspected of leaking in November 1963 due to radioactivity being detected in lateral 14-05-03 near the southeast portion of the tank. 


\subsubsection{Leak Detected in 1968-1970}

In March 1968, three years after the steam eruption, tank A-105 was declared a confirmed leaker. Two sluicing campaigns were conducted for tank A-105 in 1968 and 1970. During the first sluicing campaign from August to November 1968, radioactivity began to increase in laterals 1405-01 and 14-05-02 (see Figure 5-25). As sluicing became ineffective, sluicing was shut down in November 1968. In January 1965, low-level radioactivity was reported in drywell 10-05-10 with three peak readings recorded at 50-ft, 70-ft, and 74-ft BGS and remained relatively stable through August 1966. The next recoverable reading was in September 1972 with a peak reading at $60-\mathrm{ft} \mathrm{BGS}$ at higher radiation readings. It is likely radioactivity detected in drywell 10-05-10 is associated with the radioactivity reported in 1968 for lateral 14-05-02, which is the earliest available data for this lateral (see Section 5.5.1).

A second, more aggressive, sluicing campaign began August 1970 and was halted November 1970 after significant increases were detected in all the laterals underneath tank A-105 (see Figure 5-25).

Prior to the first sluicing campaign, the supernatant was removed from the tank and the liquid level was reported at 35-in at the end of August 1968. The liquid level in tank A-105 was then reported at 24 -in prior to the second sluicing campaign. It is likely the leak site or sites are below the 24-in waste level since radioactivity was detected in the laterals during the first sluicing campaign and increased during the second sluicing campaign.

Figure 5-25. Tank A-105 Leak Indicators (1968-1970)

Tank inner ring is steel liner; outer ring is outer edge of tank footing

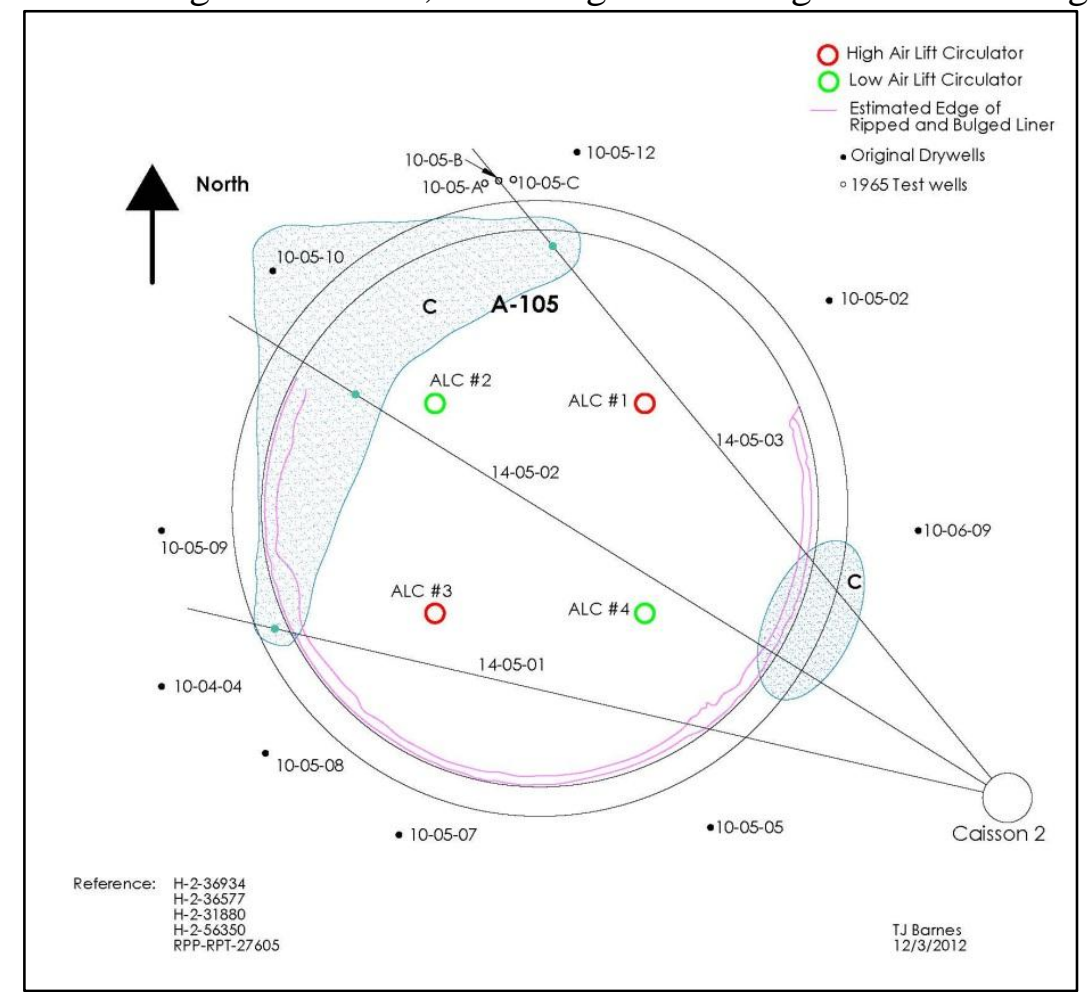

Tank A-105 was first suspected of leaking in November 1963 due to radioactivity being detected in lateral 14-05-03 near the southeast portion of the tank. 
RPP-RPT-54912, Rev. 0

\subsubsection{Leak Location Summary}

Tank A-105 was first suspected of leaking in November 1963 due to radioactivity being detected in lateral 14-05-03 in the southeast portion of the tank (see site A in Figure 5-26). It was postulated that a sidewall leak occurred during this time as the waste liquid level was raised from 260 -in to 280-in four months earlier. After the liquid level was reduced to 260-in, radiation readings in the lateral slowly decreased leading to the observation that a sidewall leak was minor and had self-healed. However, a sidewall leak remains inconclusive. No radioactivity was detected in the other laterals or drywells, and tank A-105 remained in service. Radioactivity remained relatively stable through March 1965 in lateral 14-05-03.

On January 28, 1965, a steam eruption occurred in tank A-105 causing the bottom liner to tear approximately $3 / 4$ around the perimeter of the tank. One month later, radioactivity was reported in lateral 14-05-03 in the north portion of the tank (see site B in Figure 5-26). Three test wells were drilled near the end of this lateral; however, no radioactivity or moisture was detected in these test wells indicating the leak was likely small and localized. Radioactivity was detected in drywell 10-05-02 at 74-ft BGS. The source of radioactivity may have been migration of mobile RuRh-106 from a tank A-105 leak, possibly related to the November 1963 event (see site A in Figure 5-26). However, there was no indication of radioactivity in nearby drywell 10-06-09 and the radioactivity detected in drywell 10-05-02 could have been from another source. No other drywells or laterals showed indications of radioactivity during this time.

Approximately three years after the steam eruption, tank A-105 was declared a confirmed leaker in March 1968. Two sluicing campaigns were conducted on tank A-105 in 1968 and 1970. During the first sluicing campaign in August to November 1968, radioactivity began to increase in laterals 14-05-01 and 14-05-02 near the end of these laterals along the northwestern edge of tank A-105 (see site C in Figure 5-26). Sluicing became ineffective and the first sluicing campaign was shut down in November 1968. A second, more aggressive, sluicing campaign began August 1970 and was halted in November 1970 after significant increases in radioactivity were detected in all the laterals underneath tank A-105.

A liner bulge of approximately $81 / 2$-ft was detected after the January 1965 steam eruption near the center of the tank. The liner tore approximately $3 / 4$ along the tank perimeter as a result of the steam eruption as shown below in Figure 5-26. The location of the ripped liner is superimposed on Figure 5-26 in relationship to the tank leak locations and leak indicators. It is likely that the potential liner bulge indicated in 1963 started in the south east portion of the tank as the first detection of radioactivity was at the location in lateral 14-05-03 and the most severe portion of the January 1965 liner bulging was near that portion of the tank.

Leak locations in Figure 5-26 are based on peak readings and are a representation of possible boundaries of radioactivity under the tank. The radioactivity detected in drywell 10-05-02 stands alone as there is not enough information to depict the likely specific path to the source. It should be noted that the estimated edge of the ripped and bulged liner indicates that there were various leak paths through the grout, asphaltic membrane, concrete base and soil to the actual points of detection. 
Figure 5-26. Tank A-105 Possible Radial Leak Locations and Indicators Tank inner ring is steel liner; outer ring is outer edge of tank footing

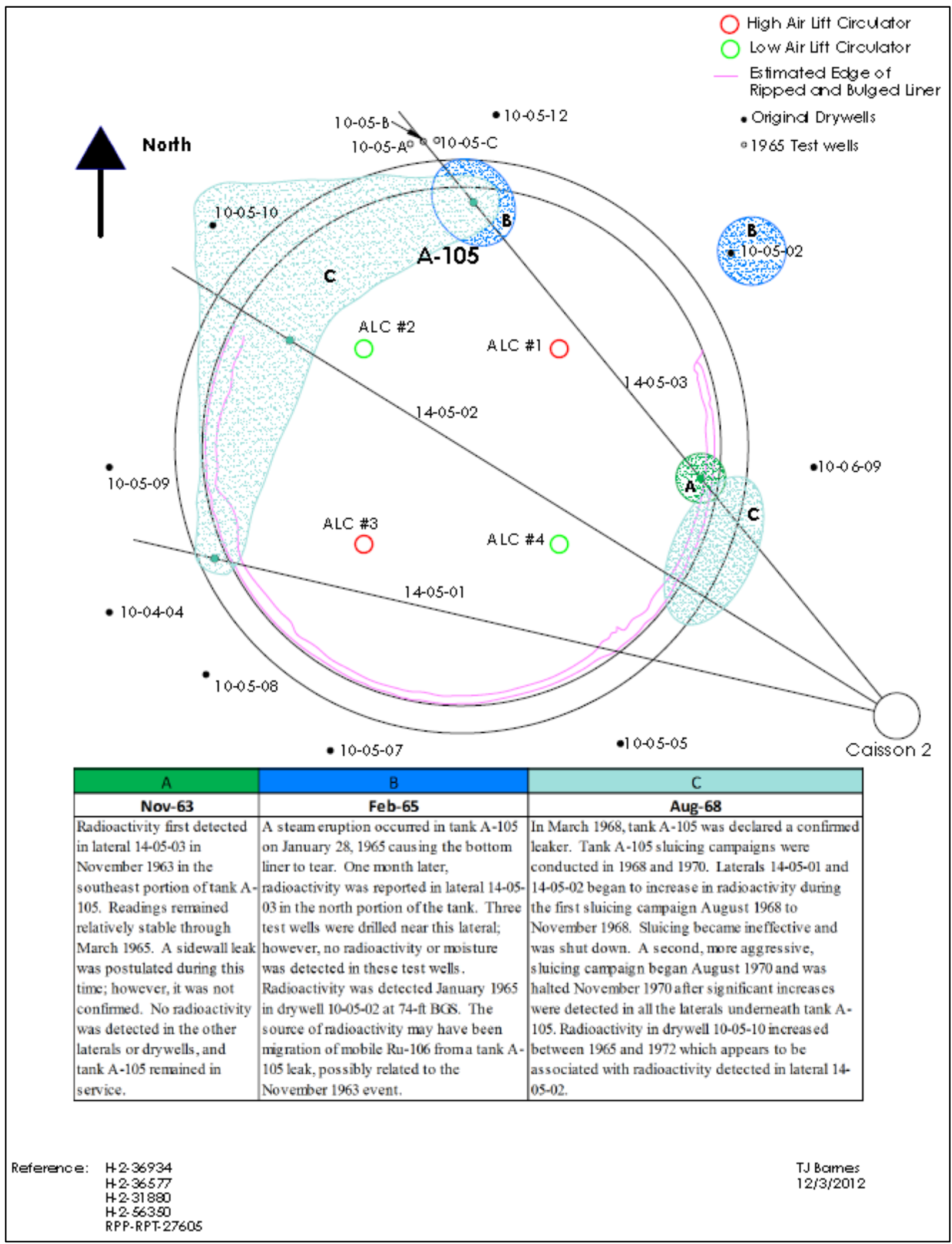


RPP-RPT-54912, Rev. 0

\subsection{POSSIBLE TANK A-105 LINER LEAK CAUSE(S)}

Tank A-105 was evaluated for five conditions known to contribute to a failed liner.

\subsubsection{Tank Design}

The design of the A Farm tanks was the second, after 241-SX Farm, that diverged from the round bottom knuckle design used in the earlier waste tanks. The flat tank bottom liner intersects the sidewall liner orthogonally. A fillet weld was used to close the seam where the sidewall and tank bottom liners meet. Several other SSTs with fillet welds failed during service (RPP-RPT-45921, Single Shell Tank Integrity Expert Panel Report). Weld inspections were less rigorous. Additionally, the design discontinued the use of the three ply asphaltic membrane waterproofing between the liner and the concrete shell. These features were inferior compared to earlier tank designs and could possibly increase the likelihood of failure of the tank liner from induced stresses (see Section 3.1.1).

\subsubsection{Thermal Conditions}

Temperature requirements in HW-59919 issued October 22, 1959 indicated that the self-boiling waste operating temperature should be maintained between $220^{\circ} \mathrm{F}$ and $250^{\circ} \mathrm{F}$. The maximum sludge temperature should not exceed $300^{\circ} \mathrm{F}$.

The tank A-105 bulb (sludge) temperatures are shown in Appendix B2. The maximum temperature of $285^{\circ} \mathrm{F}$ in January and February 1965 did not exceed the maximum sludge temperature of $300^{\circ} \mathrm{F}$.

The HW-59919 document recommended a uniform rate of temperature increase of $2^{\circ} \mathrm{F}$ per day. Temperatures were recorded as approximately $110^{\circ} \mathrm{F}$ in mid-April 1962 and gradually rose to $135^{\circ} \mathrm{F}$ by the beginning of May 1962; the temperature rate of rise was therefore approximately $1.6^{\circ} \mathrm{F} /$ day and may not have resulted in the complete removal of grout moisture. The highest temperature rate of rise occurred in February 1963 after receiving PUREX HLW directly from PUREX. During this time, temperatures rose from approximately $110^{\circ} \mathrm{F}$ on January 29,1963 to approximately $210^{\circ} \mathrm{F}$ by March 1,1963 . The temperature rate of rise was approximately $3.3^{\circ} \mathrm{F} /$ day during this time. There were no other increases in temperatures that exceeded the average rate of rise of $3.3^{\circ} \mathrm{F} /$ day during the operation of tank A-105. Exceeding the operating temperature requirements would create liner stress when thermally hot high level waste was received and stored in the tank especially without pre-heating. The most severe temperatures published occurred during addition of PUREX HLW directly from PUREX in February 1963.

Thermal shock creates stress both from rapid temperature rise as well as high temperatures.

\subsubsection{Chemistry-Corrosion}

Water was added to tank A-105 in 1955 to counteract the vacuum on the tank. Some corrosion may have occurred during the seven years when only water was in the tank. The temperatures 
during the seven years ranged from $60^{\circ} \mathrm{F}$ to $115^{\circ} \mathrm{F}$ (see Section 5.4.4). In 1962, PUREX HLW supernatant was added to the water which provided corrosion protection.

Tank A-105 stored only PUREX HLW for approximately six years and was present in the tank in November 1963, when radioactivity was initially detected in one of the laterals. According to flowsheet conditions, PUREX HLW should not result in unexpected corrosion of the tank steel liner (see Section 3.2.4).

At the end of January 1963, condensate additions were made into tank A-105 to pre-heat the tank prior to receiving PUREX HLW directly from PUREX in February 1963. The pH of the condensate additions was reported to be approximately nine, and specifications indicated additions into the A Farm tanks should be greater than a $\mathrm{pH}$ of eight (see Section 5.4.4). Therefore, the condensate additions should not result in unexpected corrosion of the tank steel liner.

No additional conditions have been identified that could accelerate corrosion of the tank steel liner.

\subsubsection{Liner Observations}

The liner bulge documented in TRAC-0022 indicated a bulge of approximately $81 / 2$ - $\mathrm{ft}$ in the central portion of tank A-105. The liner bulge was studied in-depth for tank A-105, as the pressurization event in January 1965 was the greatest one experienced at Hanford as well as the size of the bulge resulting from this event.

A review of available photographs taken August 28 and 29, 1968 confirm the bulge of the tank bottom liner; however, the extent of the torn steel liner reported in TRAC-0022 could not be located in the available photographs.

The liner bulge was reported to have been caused by vaporization of water below the tank liner and/or thermal expansion of the steel resulting in the steel liner buckling due to the orthogonal fillet weld between the tank sidewall and tank bottom.

Liner bulging coupled with other tank conditions could affect tank liner integrity; however, by itself bulging induces stresses that can cause breaching of the tank liner.

\subsubsection{Tank Construction Temperature}

The lowest average temperatures during construction of the A Farm tank liners occurred in December 1954 at $34^{\circ} \mathrm{F}$ and January 1955 at $30^{\circ} \mathrm{F}$ with four months having at least one minimum temperature between $14^{\circ} \mathrm{F}$ and $18^{\circ} \mathrm{F}$ (see Section 5.3.2). The low temperatures experienced during construction were less than the $18^{\circ} \mathrm{F}$ allowable temperature where impact loading had the potential for creating micro-fissures. Impact occurrences may have triggered fissures in the steel liner. 
RPP-RPT-54912, Rev. 0

\subsection{TANK A-105 CONCLUSIONS}

Evidence indicates that the tank A-105 liner leaked at or near the tank footing. Based on engineering judgment and available information the following conditions contributed to the tank A-105 failed liner:

- Thermal conditions - initial grout moisture pressurization caused bulging and partial failure of the tank bottom liner which could allow re-introduction of moisture into the grout coupled with high temperatures causing ultimate bottom liner failure

- Liquid level control - transfer of waste to 10-in liquid level

- Tank design - expansion limiting design

- Superheated waste trapped under the tank bottom liner - complete failure of tank bottom liner

- Secondary contributing causes

- Chemistry - corrosion from long term storage of inhibited water

- Construction conditions - ductile-to-brittle transition temperature

There are several liner leak cause conditions that were examined but the most likely cause of the initial tank A-105 leak indication in November 1963 was the previous transfer of supernatant down to 10-in of liquid without adequate grout moisture removal and subsequent heating to boiling conditions. This could have set up a transient differential pressure condition between any residual grout vapor pressure below the tank bottom liner and hydrostatic pressure above the tank bottom liner. The differential coupled with the tank vacuum could have resulted in a bulged tank bottom liner possibly causing fissures in the tank bottom liner.

The tank design also contributed by not allowing expansion of the bottom liner as the tank heated which could have creating additional stresses. Fissures in the tank bottom liner would have allowed the introduction of condensate/HLW into the bulged area as the tank was refilled. The bulge trapped liquid could have resulted in the liquid level cycling in September 1963 as the area beneath the bulge first pressurized with vapor, expelling the remaining liquid, and then allowing liquid to refill the bulge beginning a new expulsion oscillation resulting in further compromising the integrity of the tank bottom liner. The hydrostatic head eventually increased to the equivalent HLW concentration of 11,000 tons of PUREX feed until the vapor pressure of the liquid under the bulge created a superheated steam event January 28, 1965 ripping the bottom liner resulting in further leakage.

Chemistry-corrosion and construction conditions could have also contributed to the tank bottom liner failure but to a lesser degree. 
RPP-RPT-54912, Rev. 0

APPENDIX A2

TANK A-105 BOILING WASTE OPERATIONAL HISTORY 
Table A2-1. RHO-R-39 Boiling Waste Tank Operating Data Table

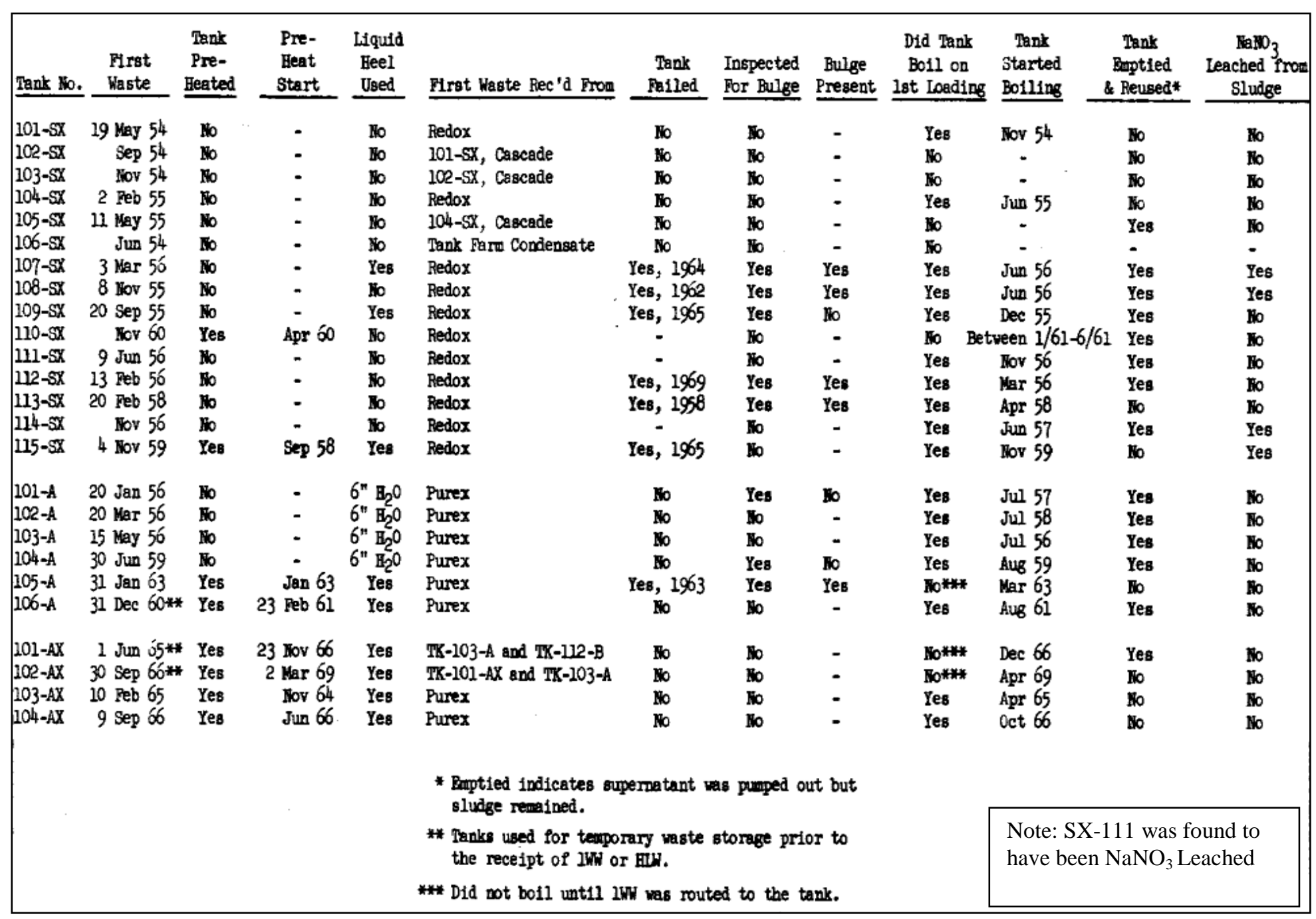


RPP-RPT-54912, Rev. 0

Table A2-2. ARH-R-43 Waste Tank Leak Experience Table

\begin{tabular}{|c|c|c|c|c|c|c|c|c|c|c|}
\hline $\begin{array}{l}\text { TADEE } 3 \\
\text { Tank } \\
\end{array}$ & $\begin{array}{l}\text { Wnderg } \\
\text { Built }\end{array}$ & $\begin{array}{l}\text { rourd: } \\
\text { First } \\
\text { Used }\end{array}$ & $\begin{array}{l}\text { azte Storago Fank Lea? Ex } \\
\text { Type of kaste Stored }\end{array}$ & $x p e r i \in n \in e$ & $\begin{array}{l}\text { Leak First } \\
\text { Suspected } \\
\end{array}$ & $\begin{array}{l}\text { Reason for } \\
\text { Suspicion }\end{array}$ & $\begin{array}{cc}\text { Leak Confirmed } \\
\text { by }\end{array}$ & $\begin{array}{l}\text { Bulge } \\
\text { Found } \\
\end{array}$ & $\begin{array}{l}\text { Estimated } \\
\text { Volune of } \\
\text { Leak, ga I } \\
\end{array}$ & $\begin{array}{l}\text { Associated } \\
\mathrm{Cs} .137, \mathrm{kCi}\end{array}$ \\
\hline $104-U$ & 1943.44 & 1947 & $\begin{array}{l}\text { Bismuth phosphate waste } \\
\text { Uranium recovery waste }\end{array}$ & Nonboiling & 1956 & Bulged 1 iner & $\begin{array}{l}\text { Refill with } \\
\text { water (1961) }\end{array}$ & Yes & $55,000^{*}$ & 0.09 \\
\hline $11.5-5 x$ & $1953-54$ & 1958 & Redox waste & Rotitug & 1958 & Bulged 1 iner & $\begin{array}{l}\text { Refill with salt } \\
\text { solution }(1962)\end{array}$ & Yes & $15,000 * *$ & 8 \\
\hline $106-\mathrm{Tr}$ & 1951.52 & 1953 & THP waste & Nonboiling & 1959 & $\begin{array}{l}\text { Liquid leve } 1 \\
\text { measurettents }\end{array}$ & $\begin{array}{l}\text { Soil radiation } \\
\text { readings (1959) }\end{array}$ & & 20,000 & 2 \\
\hline $101 \cdot U$ & $1943 \cdot 44$ & 1946 & $\begin{array}{l}\text { Bismuth phosphate waste } \\
\text { Uranium recovery waste } \\
\text { Redox kaste }\end{array}$ & Nonboiling & 1959 & $\begin{array}{l}\text { Liquid leve } 1 \\
\text { measurements }\end{array}$ & $\begin{array}{l}\text { Liquid leve } 1 \\
\text { measurements }\end{array}$ & & 30,000 & 23 \\
\hline $105=\mathrm{rY}$ & $1951 \cdot 52$ & 1953 & TBp vaste & Sonboiling & 1960 & $\begin{array}{l}\text { 1. iquid leve } 1 \\
\text { measurements }\end{array}$ & $\begin{array}{l}\text { Liquid level } \\
\text { measurements }\end{array}$ & & 35,000 & 4 \\
\hline $108-5 x$ & $1953-54$ & 1955 & Redox waste & Boiling & 1962 & $\begin{array}{l}\text { Soil radi- } \\
\text { ation } \\
\text { readings }\end{array}$ & $\begin{array}{l}\text { Liquid level } \\
\text { measurements }\end{array}$ & Yes & 3,400 & 17 \\
\hline $105 \cdot A$ & $1954-53$ & 1963 & Purex waste & Boiling & 1963 & $\begin{array}{l}\text { Soil radi- } \\
\text { ation } \\
\text { readings }\end{array}$ & $\begin{array}{l}\text { Soil radiation } \\
\text { readings }\end{array}$ & Yes & Sma11 & \\
\hline $107-5 x$ & $1953-54$ & 1956 & Redox waste & Boiling & 1964 & $\begin{array}{l}\text { Soil radi- } \\
\text { ation } \\
\text { readings }\end{array}$ & $\begin{array}{l}\text { Soil } 1 \text { radiation } \\
\text { readings }\end{array}$ & Yes & Smal 1 & \\
\hline $109-\$ x$ & $1953-54$ & 1955 & Redox waste & Boiling & 1965 & $\begin{array}{l}\text { Soil radi= } \\
\text { ation } \\
\text { readings }\end{array}$ & $\begin{array}{l}\text { No further } \\
\text { evidence }\end{array}$ & No & Sma11 & \\
\hline $115=\$ x$ & $1953 \cdot 54$ & 1958 & Redox waste & Boiling & 1965 & $\begin{array}{l}\text { Liquid level } \\
\text { measurements }\end{array}$ & $\begin{array}{l}\text { Soil radiation } \\
\text { readings }\end{array}$ & & $50,000 * * \star$ & 40 \\
\hline $112-5 X$ & $1953-54$ & 1956 & Redox waste & Boiling & 1969 & $\begin{array}{l}\text { I.iquid level } \\
\text { measurements }\end{array}$ & $\begin{array}{l}\text { Soil radiation } \\
\text { teadings }\end{array}$ & Yes & 30,000 & 45 \\
\hline $\begin{array}{ll}A & c=1 \\
A & c o n\end{array}$ & $\begin{array}{l}\text { ntained } \\
\text { rtained } \\
\text { ritained }\end{array}$ & 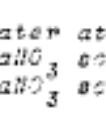 & $\begin{array}{l}\text { tine leat. } \\
\text { intion at tire of loak. } \\
\text { intion at time of leak. }\end{array}$ & 86 Jost: & al abse & ataret esantion. & & & & \\
\hline
\end{tabular}

Note: See tank farm segments for information on individual specific tanks 
RPP-RPT-54912, Rev. 0

APPENDIX B2

TANK A-105 TEMPERATURES APRIL 1958-JUNE 1970 
RPP-RPT-54912, Rev. 0

Figure B2-1. RHO-CD-1172 Tank A-105 Temperature April 1958 through July 1958

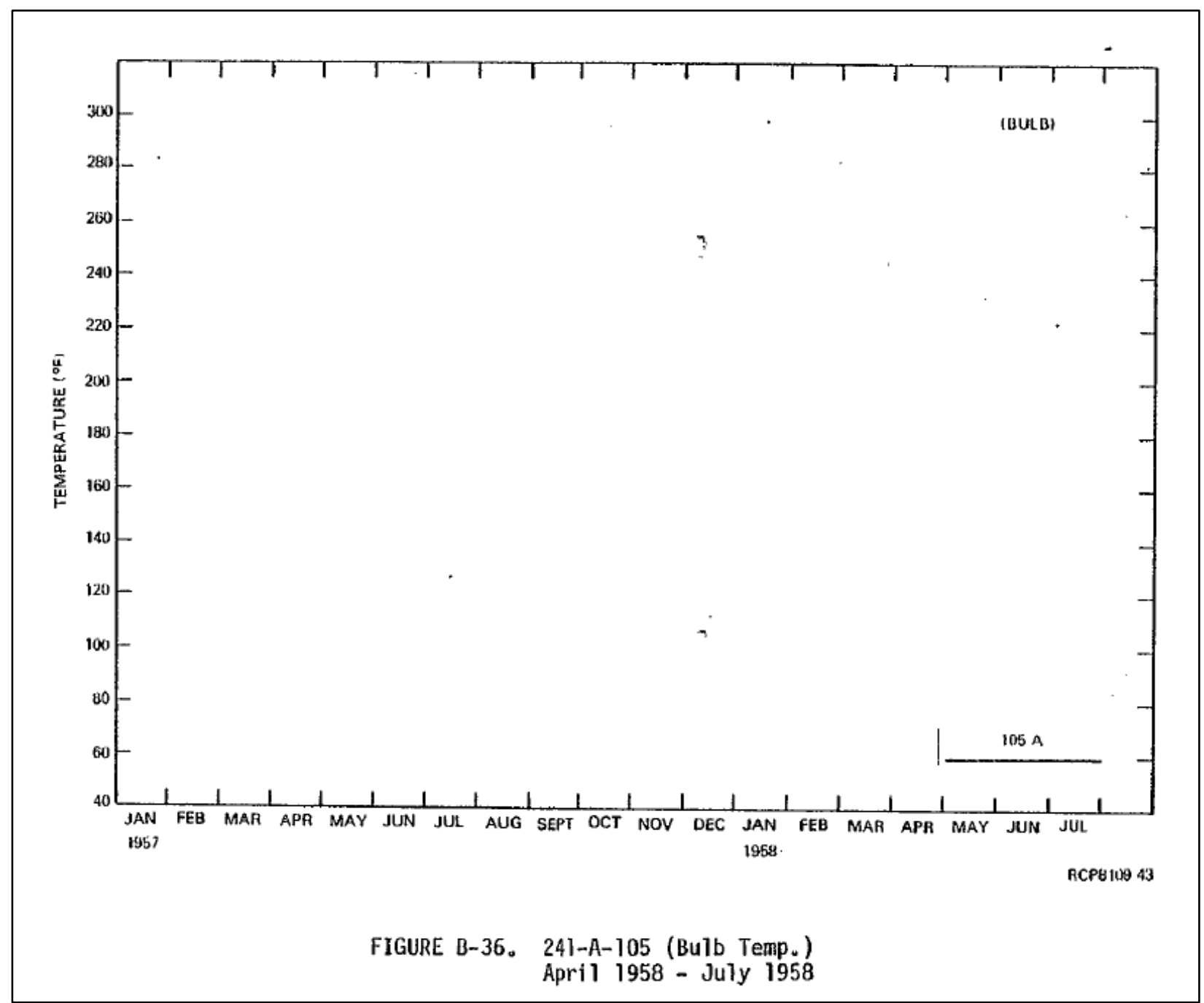

Note: Bulb (sludge) temperature 2-in to 3-in off the tank bottom (see Section 3.2.2) 
RPP-RPT-54912, Rev. 0

Figure B2-2. RHO-CD-1172 Tank A-105 Temperature August 1958 through February 1960

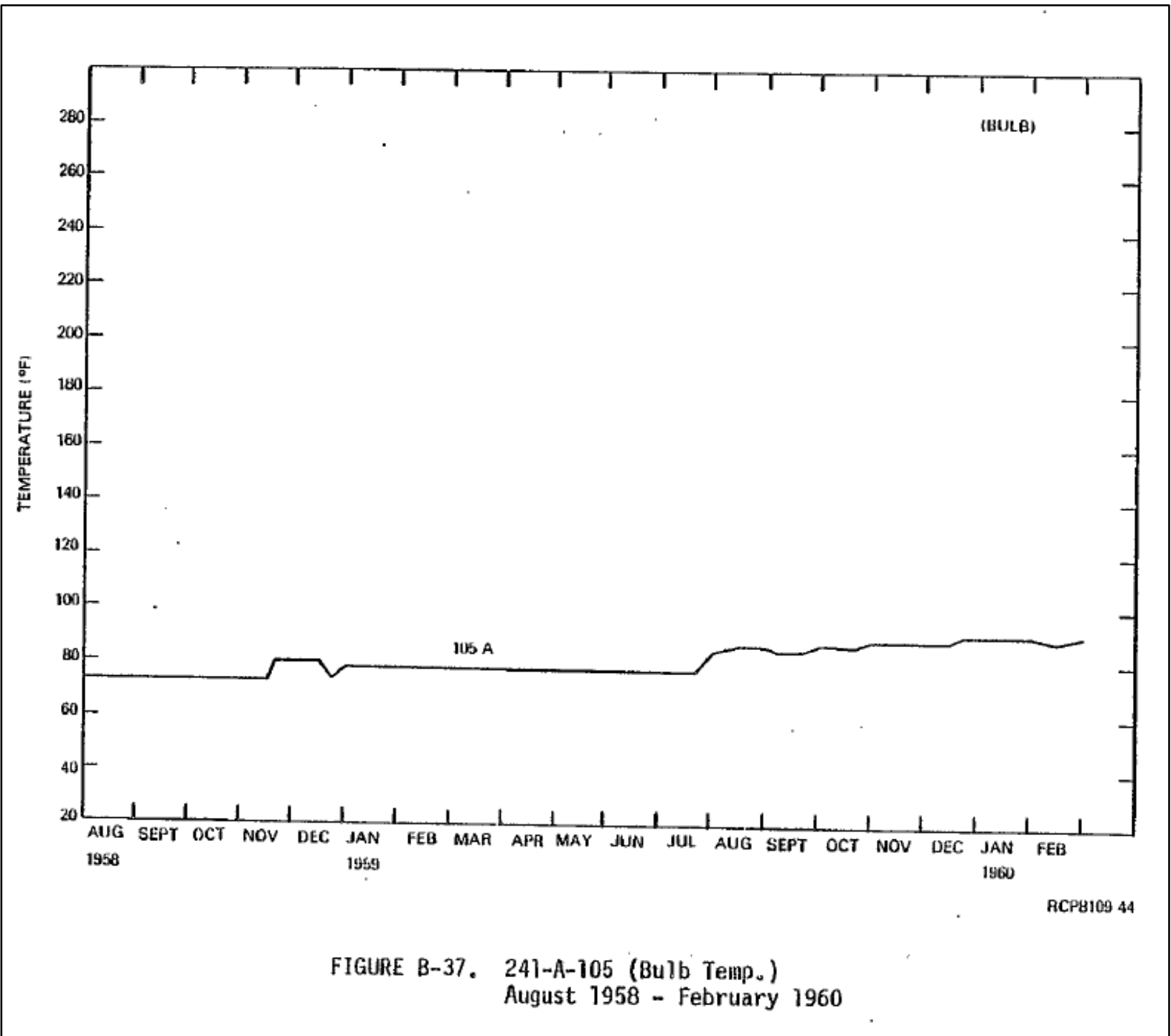

Note: Bulb (sludge) temperature 2-in to 3-in off the tank bottom (see Section 3.2.2) 
RPP-RPT-54912, Rev. 0

Figure B2-3. RHO-CD-1172 Tank A-105 Temperature March 1960 through September 1961

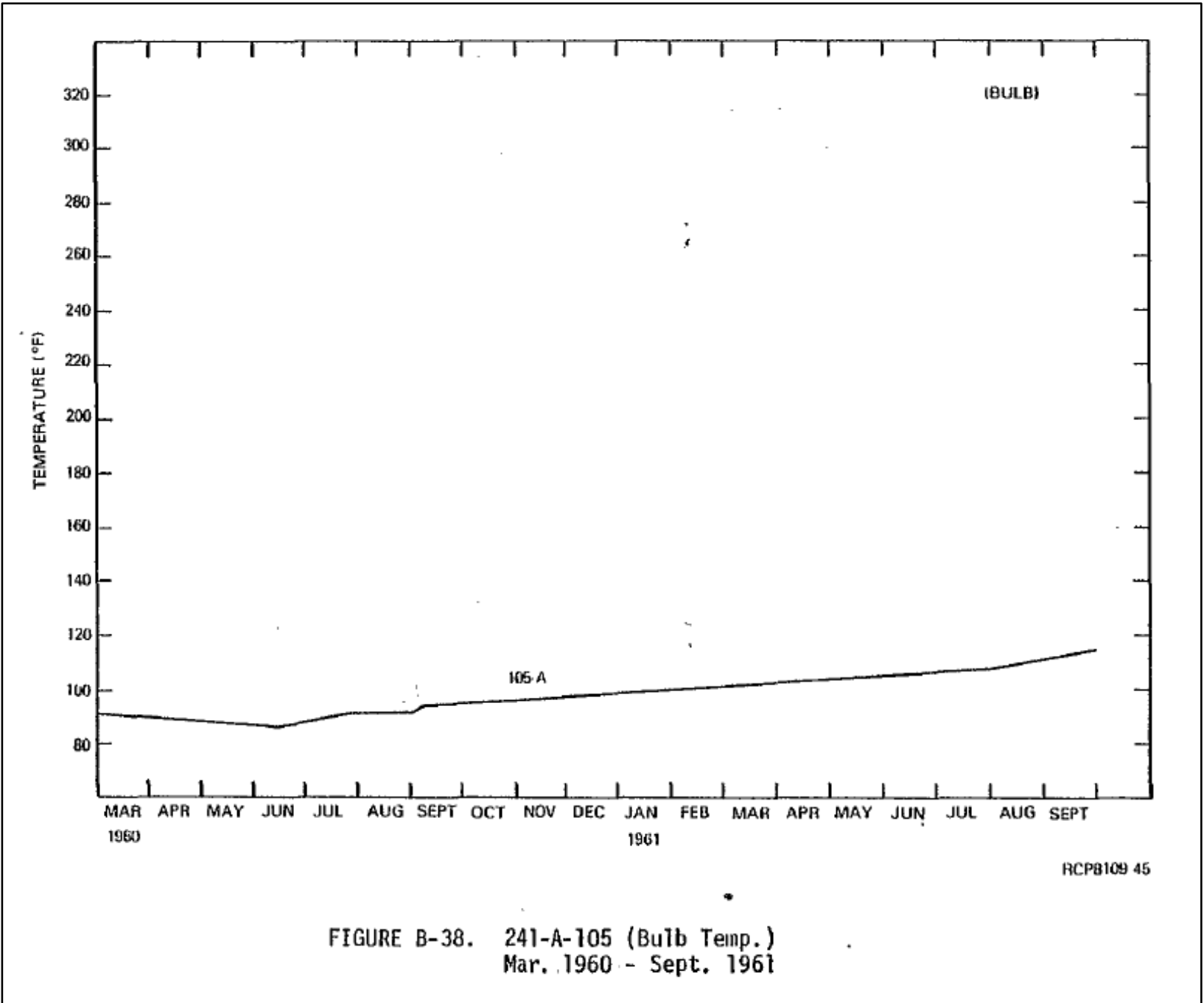

Note: Bulb (sludge) temperature 2-in to 3-in off the tank bottom (see Section 3.2.2) 
RPP-RPT-54912, Rev. 0

Figure B2-4. RHO-CD-1172 Tank A-105 Temperature October 1961 through April 1963

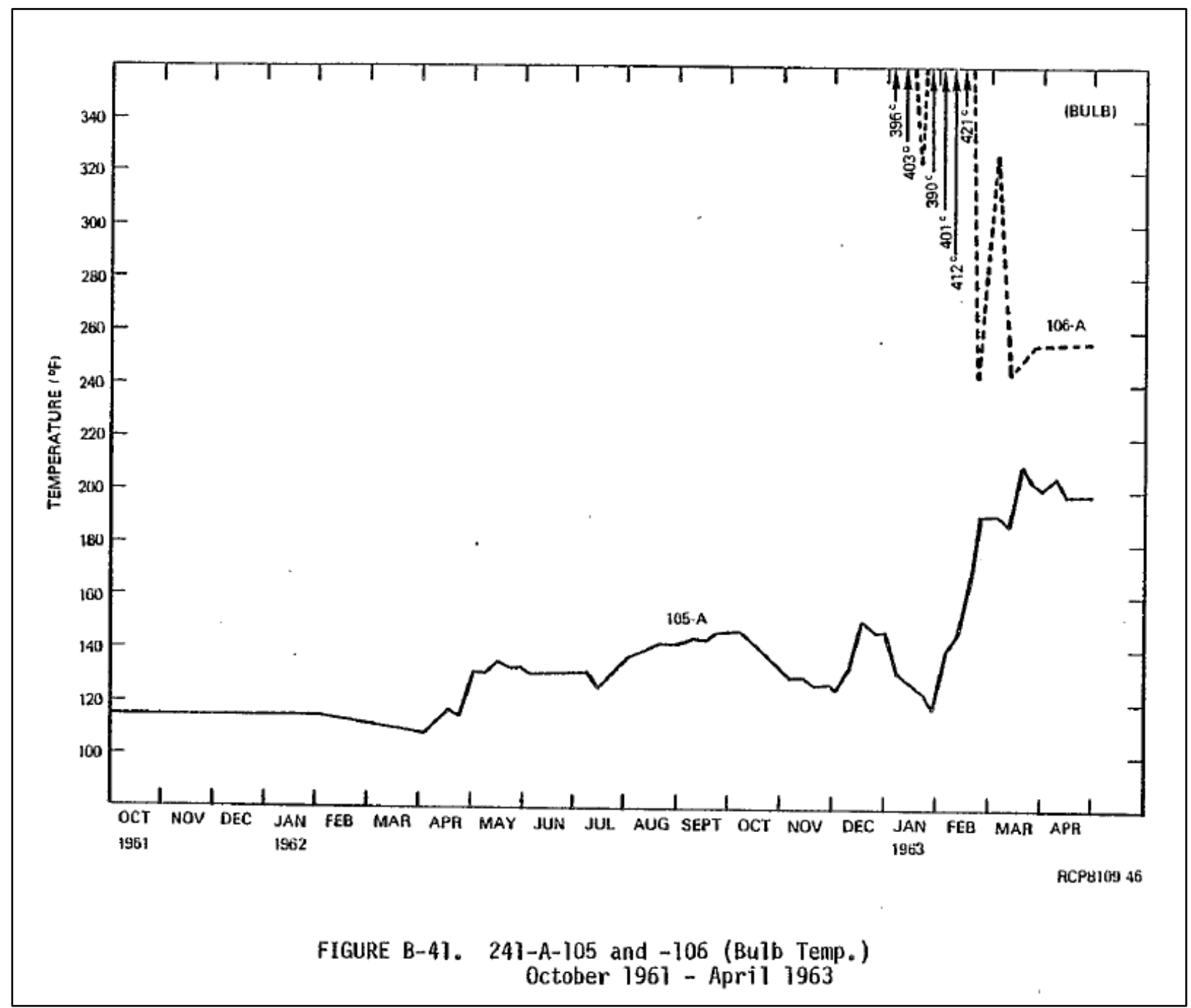

Note: Bulb (sludge) temperature 2-in to 3-in off the tank bottom (see Section 3.2.2) 
RPP-RPT-54912, Rev. 0

Figure B2-5. RHO-CD-1172 Tank A-105 Temperature May 1963 through November 1964

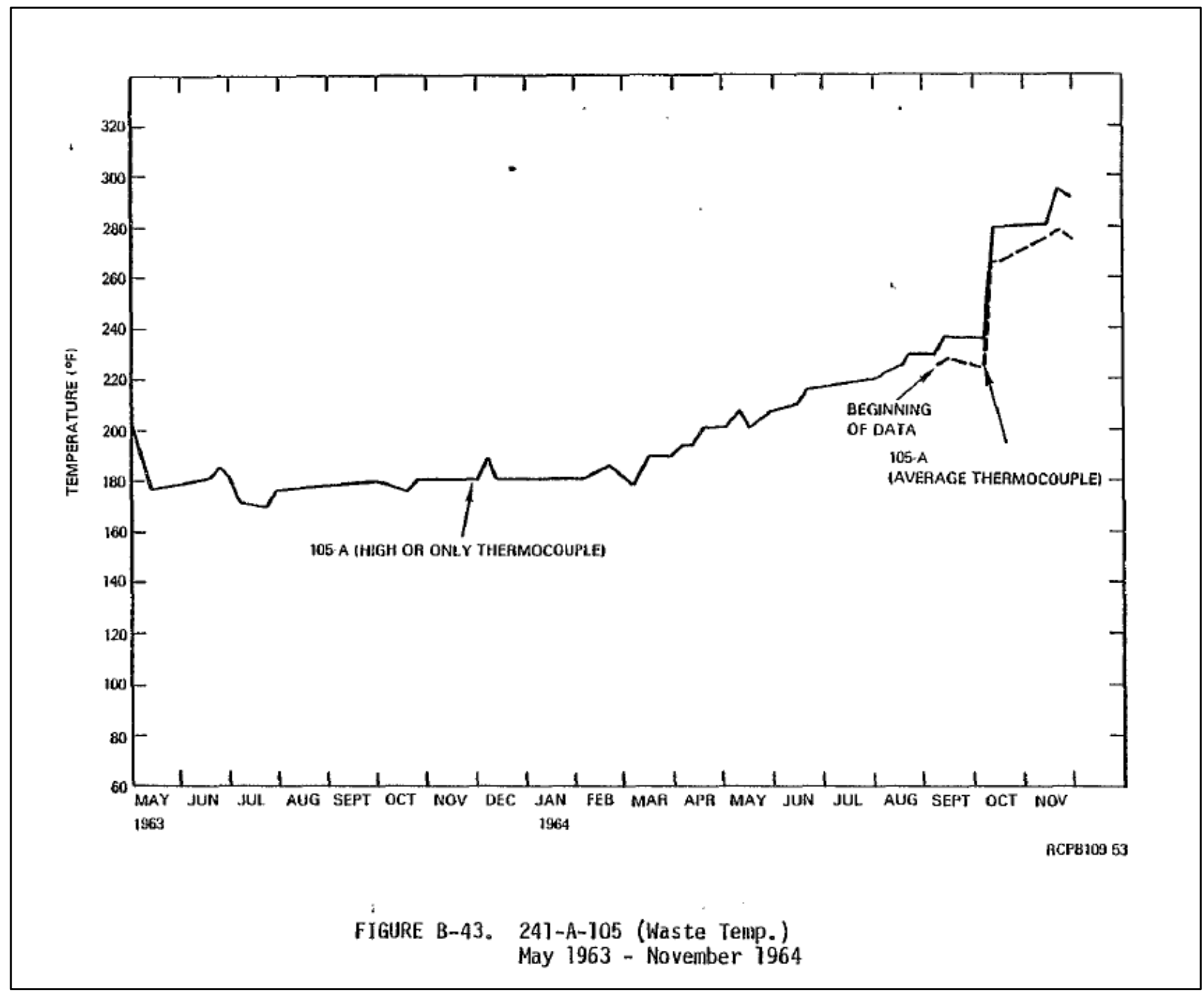

Note: Bulb (sludge) temperature 2-in to 3-in off the tank bottom (see Section 3.2.2) 
Figure B2-6. RHO-CD-1172 Tank A-105 Temperature December 1964 through June 1966

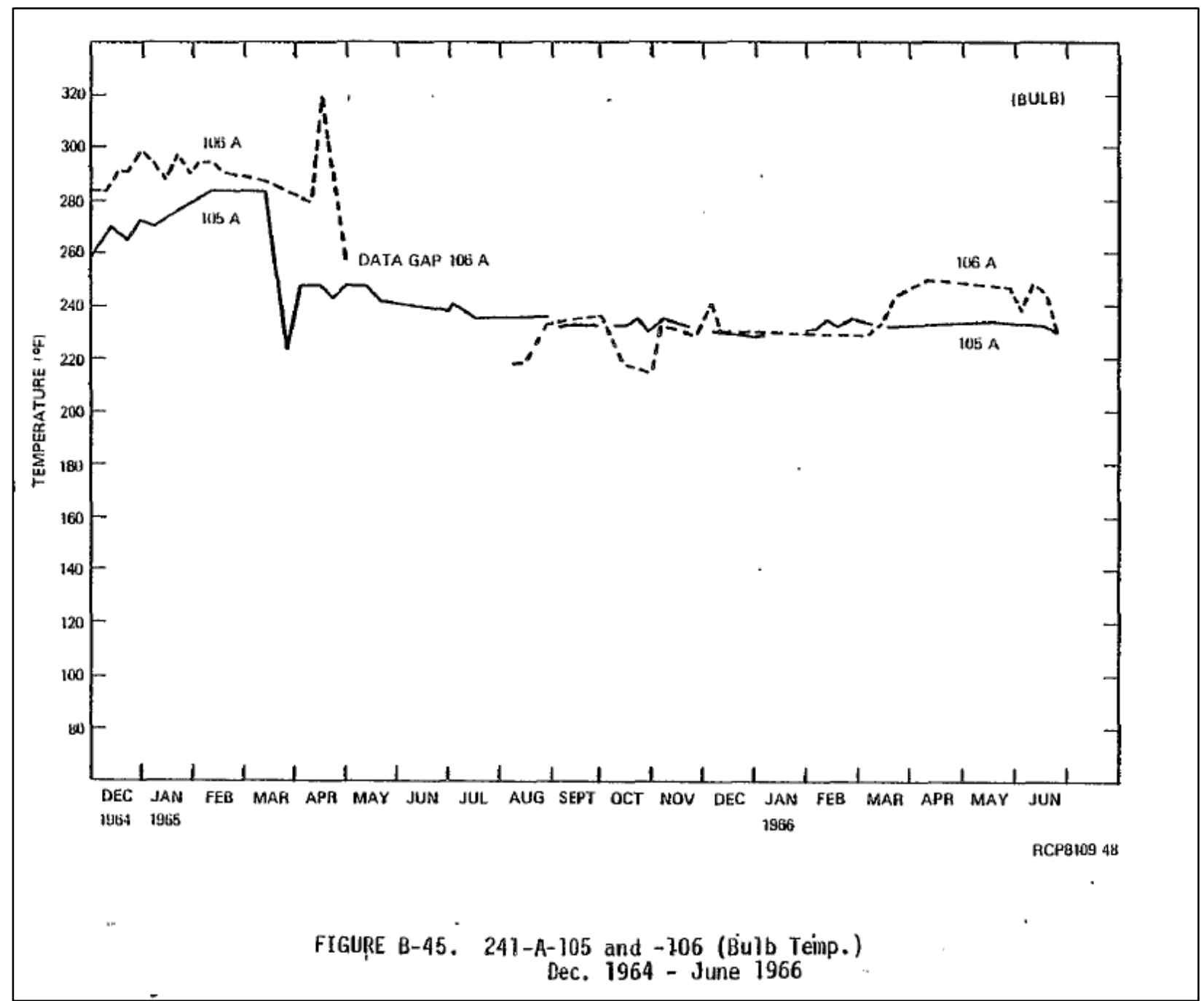

Note: Bulb (sludge) temperature 2-in to 3-in off the tank bottom (see Section 3.2.2) 
RPP-RPT-54912, Rev. 0

Figure B2-7. RHO-CD-1172 Tank A-105 Temperature July 1966 through January 1968

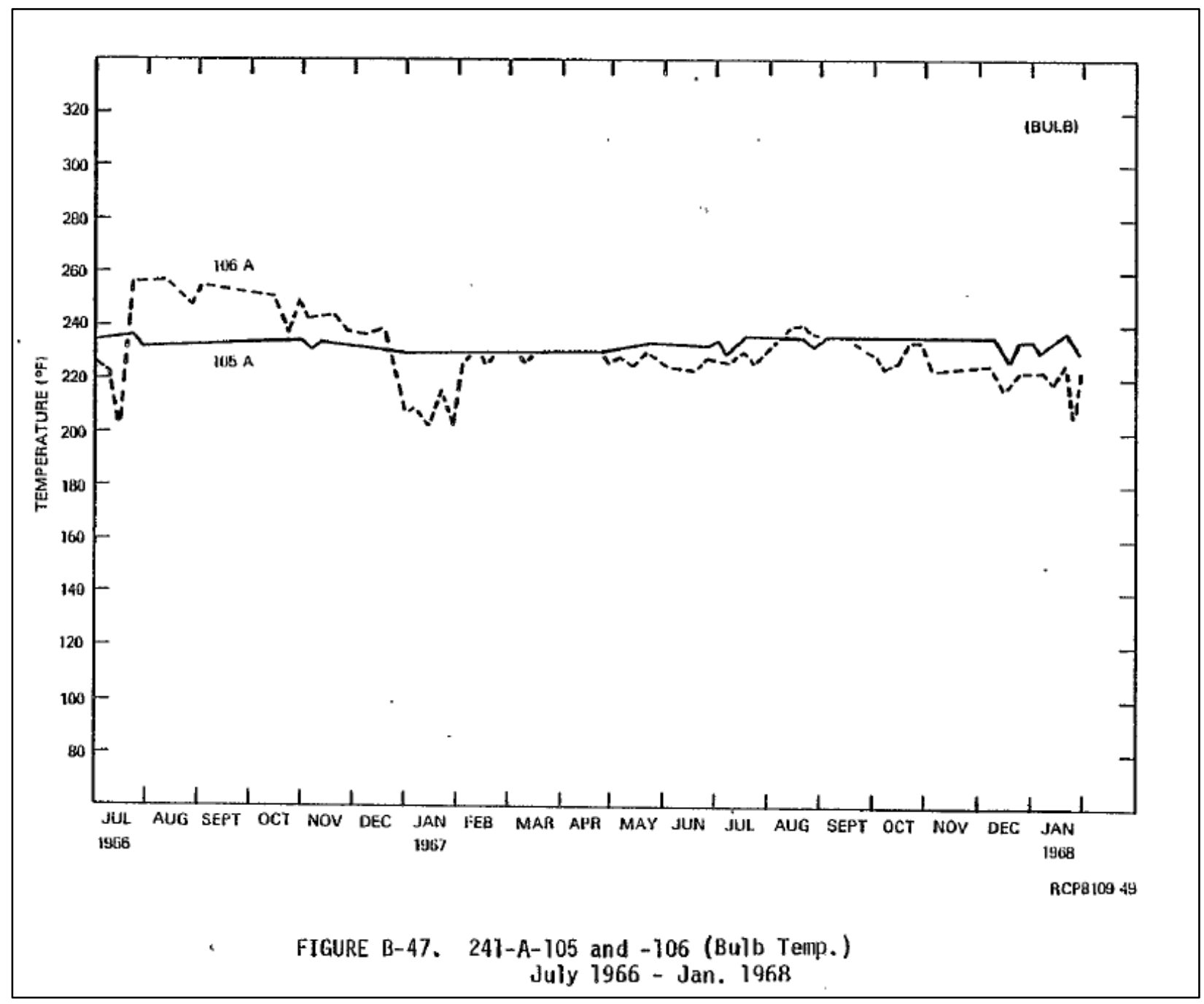

Note: Bulb (sludge) temperature 2-in to 3-in off the tank bottom (see Section 3.2.2) 
RPP-RPT-54912, Rev. 0

Figure B2-8. RHO-CD-1172 Tank A-105 Temperature February 1968 through August 1969

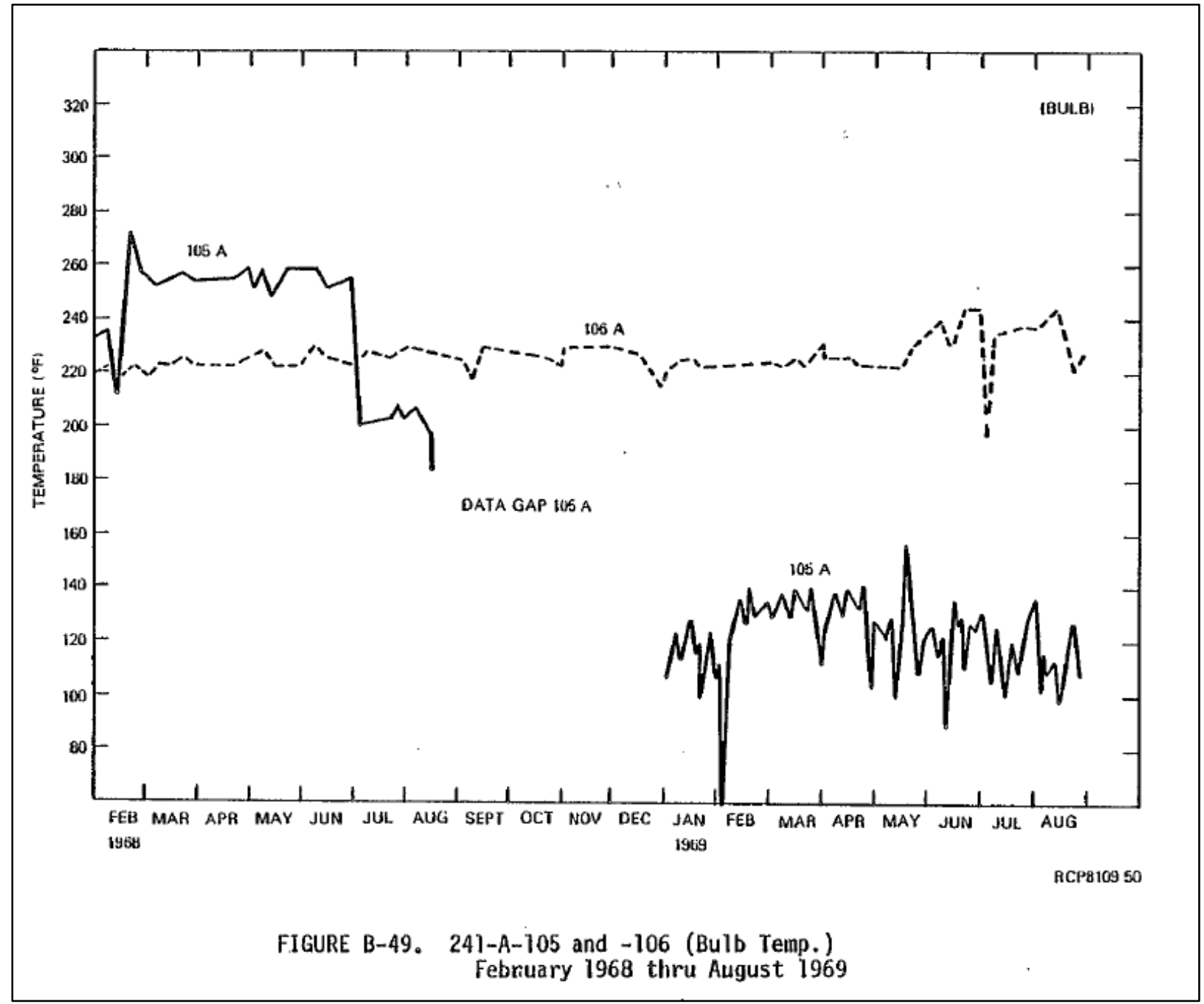

Note: Bulb (sludge) temperature 2-in to 3-in off the tank bottom (see Section 3.2.2) 
RPP-RPT-54912, Rev. 0

Figure B2-9. RHO-CD-1172 Tank A-105 Temperature September 1969 through June 1970

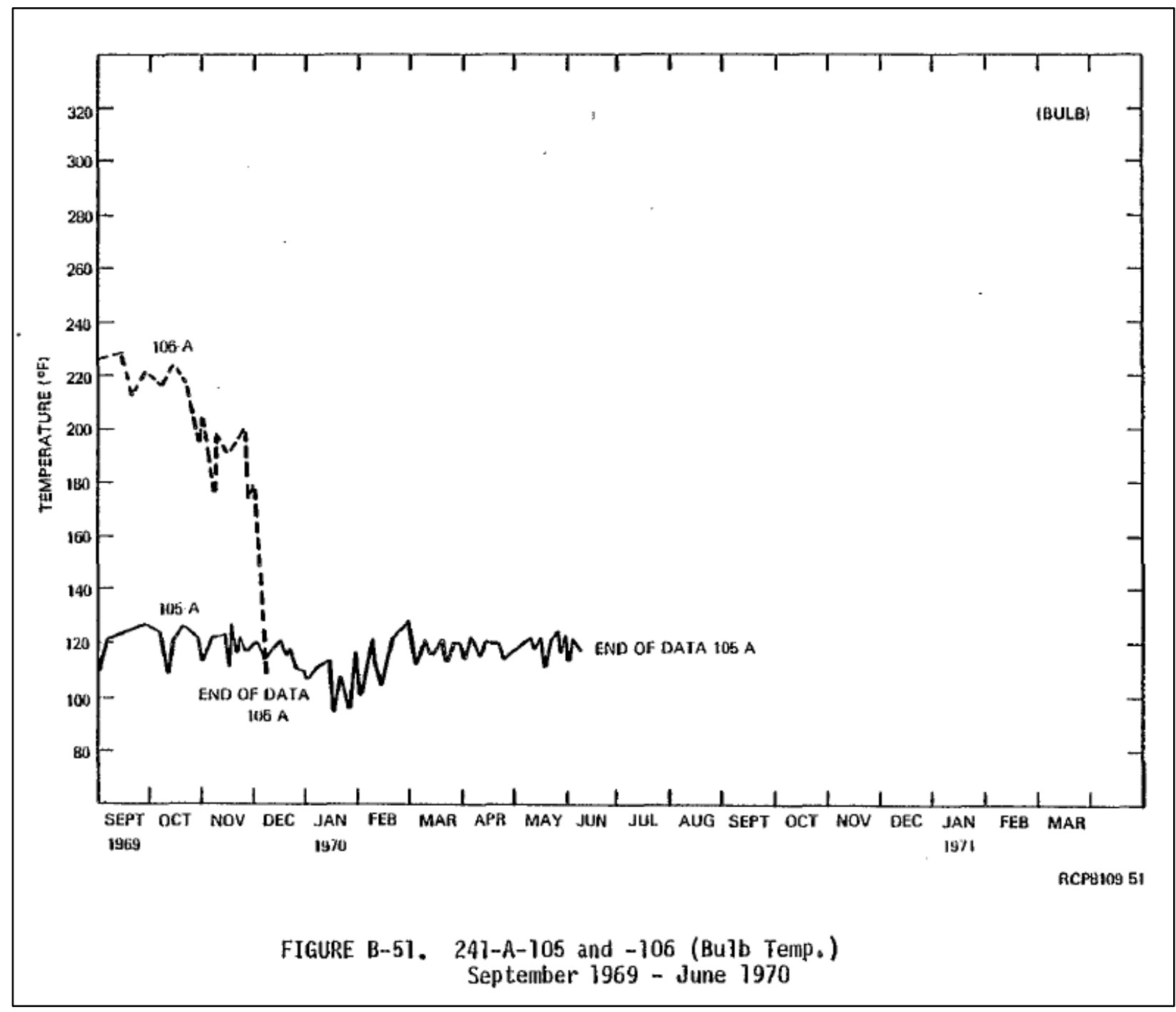

Note: Bulb (sludge) temperature 2-in to 3-in off the tank bottom (see Section 3.2.2) 
RPP-RPT-54912, Rev. 0

\section{APPENDIX C2}

TANK A-105 LATERAL ACTIVITY

C2-1 
RPP-RPT-54912, Rev. 0

Table C2-1. Tank 241-A-105 Lateral Radioactivity (K counts per minute) (September 1972 through June 1986)

(SD-WM-TI-356) (1 of 2 sheets)

\begin{tabular}{|c|c|c|c|c|c|c|c|c|}
\hline \multicolumn{3}{|c|}{$14-05-01$} & \multicolumn{3}{|c|}{ 14-05-02 } & \multicolumn{3}{|c|}{ 14-05-03 } \\
\hline Date & $\begin{array}{c}\text { Peak (K } \\
\text { cpm) }\end{array}$ & $\begin{array}{l}\text { Length } \\
(\mathrm{ft})^{5}\end{array}$ & Date & $\begin{array}{c}\text { Peak (K } \\
\text { cpm) }\end{array}$ & Length $(\mathrm{ft})^{5}$ & Date & Peak (K cpm) & Length (ft) ${ }^{5}$ \\
\hline \multicolumn{3}{|c|}{ N/A ${ }^{2}$} & \multicolumn{3}{|c|}{$\mathrm{N} / \mathrm{A}^{2}$} & $11 / 19 / 63$ & $17^{1}$ & $44.6^{6}$ \\
\hline \multicolumn{3}{|c|}{$\mathrm{N} / \mathrm{A}^{2}$} & \multicolumn{3}{|c|}{$\mathrm{N} / \mathrm{A}^{2}$} & $11 / 26 / 63$ & $150^{1}$ & $44.6^{6}$ \\
\hline \multicolumn{3}{|c|}{$\mathrm{N} / \mathrm{A}^{2}$} & \multicolumn{3}{|c|}{$\mathrm{N} / \mathrm{A}^{2}$} & $3 / 8 / 65$ & $195^{1}$ & $95.6^{6}$ \\
\hline \multicolumn{3}{|c|}{$\mathrm{N} / \mathrm{A}^{2}$} & \multicolumn{3}{|c|}{$\mathrm{N} / \mathrm{A}^{2}$} & $01 / 31 / 66$ & $225^{7}$ & $\mathrm{~N} / \mathrm{A}^{2}$ \\
\hline \multicolumn{3}{|c|}{$\mathrm{N} / \mathrm{A}^{2}$} & \multicolumn{3}{|c|}{$\mathrm{N} / \mathrm{A}^{2}$} & $02 / 28 / 66$ & $225^{7}$ & $\mathrm{~N} / \mathrm{A}^{2}$ \\
\hline \multicolumn{3}{|c|}{$\mathrm{N} / \mathrm{A}^{2}$} & \multicolumn{3}{|c|}{$\mathrm{N} / \mathrm{A}^{2}$} & $03 / 31 / 66$ & $225^{7}$ & N/A ${ }^{2}$ \\
\hline \multicolumn{3}{|c|}{$\mathrm{N} / \mathrm{A}^{2}$} & \multicolumn{3}{|c|}{$\mathrm{N} / \mathrm{A}^{2}$} & $4 / 30 / 66$ & $225^{7}$ & $\mathrm{~N} / \mathrm{A}^{2}$ \\
\hline \multicolumn{3}{|c|}{$\mathrm{N} / \mathrm{A}^{2}$} & \multicolumn{3}{|c|}{$\mathrm{N} / \mathrm{A}^{2}$} & $5 / 31 / 66$ & $225^{7}$ & $\mathrm{~N} / \mathrm{A}^{2}$ \\
\hline \multicolumn{3}{|c|}{$\mathrm{N} / \mathrm{A}^{2}$} & $10 / 2 / 67$ & $2^{8}$ & $\mathrm{~N} / \mathrm{A}^{2}$ & \multicolumn{3}{|c|}{$\mathrm{N} / \mathrm{A}^{2}$} \\
\hline \multicolumn{3}{|c|}{$\mathrm{N} / \mathrm{A}^{2}$} & $8 / 25 / 68$ & 150 & 100 & \multicolumn{3}{|c|}{$\mathrm{N} / \mathrm{A}^{2}$} \\
\hline \multicolumn{3}{|c|}{$\mathrm{N} / \mathrm{A}^{2}$} & $9 / 1 / 68$ & 380 & 100 & \multicolumn{3}{|c|}{$\mathrm{N} / \mathrm{A}^{2}$} \\
\hline \multicolumn{3}{|c|}{$\mathrm{N} / \mathrm{A}^{2}$} & $9 / 8 / 68$ & 410 & N/A ${ }^{2}$ & \multicolumn{3}{|c|}{$\mathrm{N} / \mathrm{A}^{2}$} \\
\hline $10 / 29 / 68^{9}$ & $20^{1}$ & $\mathrm{~N} / \mathrm{A}^{2}$ & $10 / 29 / 68^{9}$ & $190^{1}$ & $\mathrm{~N} / \mathrm{A}^{2}$ & $10 / 29 / 68^{9}$ & $120^{1}$ & $\mathrm{~N} / \mathrm{A}^{2}$ \\
\hline $8 / 70$ & $40^{1}$ & $\mathrm{~N} / \mathrm{A}^{2}$ & $8 / 70$ & $375^{1}$ & $\mathrm{~N} / \mathrm{A}^{2}$ & $8 / 70$ & $960^{1}$ & $\mathrm{~N} / \mathrm{A}^{2}$ \\
\hline $9 / 13 / 72$ & 16.6 & 98 & $9 / 8 / 72$ & 198 & 40 & $9 / 11 / 72$ & 580 & 93 \\
\hline $4 / 26 / 74$ & 11.6 & 98 & $4 / 26 / 74$ & 175 & 40 & $4 / 26 / 74$ & 485 & 93 \\
\hline $1 / 3 / 75$ & 4.4 & 98 & $1 / 6 / 75$ & 77 & 50 & $1 / 10 / 75$ & 192 & 93 \\
\hline $5 / 12 / 75$ & 3.9 & 98 & $5 / 12 / 75$ & 51 & 35 & $6 / 2 / 75$ & 202.5 & 93 \\
\hline $8 / 15 / 75$ & 6.2 & 98 & $8 / 15 / 75$ & 54 & 48 & $8 / 18 / 75$ & 199.5 & 93 \\
\hline $1 / 7 / 76$ & 6.3 & 98 & $1 / 21 / 76$ & 54 & 48 & $1 / 5 / 76$ & 198 & 96 \\
\hline $6 / 4 / 76$ & 5.8 & 94 & $8 / 30 / 76$ & 79.3 & 49 & $8 / 30 / 76$ & 273 & 94 \\
\hline $9 / 10 / 76$ & 7.5 & 94 & \multicolumn{3}{|c|}{ N/A ${ }^{2}$} & $10 / 4 / 76$ & 347 & 94 \\
\hline $12 / 6 / 76$ & 7.7 & 94 & $12 / 8 / 76$ & 82 & 49 & $12 / 8 / 76$ & 356 & 93 \\
\hline $3 / 28 / 77$ & 7.3 & 94 & $3 / 28 / 77$ & 80.7 & 49 & $3 / 28 / 77$ & 310 & 93 \\
\hline $6 / 9 / 77$ & 23 & 89.6 & \multicolumn{3}{|c|}{$\mathrm{N} / \mathrm{A}^{2}$} & \multicolumn{3}{|c|}{$\mathrm{N} / \mathrm{A}^{2}$} \\
\hline $6 / 17 / 77$ & $24^{3}$ & 88.6 & $6 / 17 / 77$ & $195^{3}$ & 35.6 & $6 / 16 / 77$ & $720^{3}$ & 97.6 \\
\hline $9 / 5 / 77$ & 27 & 89.6 & $9 / 5 / 77$ & 180 & 28.6 & $9 / 5 / 77$ & 648 & 95.6 \\
\hline
\end{tabular}

C2-2 
RPP-RPT-54912, Rev. 0

Table C2-1. Tank 241-A-105 Lateral Radioactivity (K counts per minute) (September 1972 through June 1986)

(SD-WM-TI-356) ( 2 of 2 sheets)

\begin{tabular}{|c|c|c|c|c|c|c|c|c|}
\hline \multicolumn{3}{|c|}{ 14-05-01 } & \multicolumn{3}{|c|}{ 14-05-02 } & \multicolumn{3}{|c|}{ 14-05-03 } \\
\hline Date & $\begin{array}{c}\text { Peak (K } \\
\text { cpm) }\end{array}$ & $\begin{array}{l}\text { Length } \\
(\mathrm{ft})^{5}\end{array}$ & Date & $\begin{array}{c}\text { Peak (K } \\
\text { cpm) }\end{array}$ & Length $(f t)^{5}$ & Date & Peak (K cpm) & Length $(f t)^{5}$ \\
\hline $12 / 9 / 77$ & 26 & 89.6 & $12 / 9 / 77$ & 162 & 28.6 & $12 / 9 / 77$ & 570 & 95.6 \\
\hline \multicolumn{3}{|c|}{$\mathrm{N} / \mathrm{A}^{2}$} & \multicolumn{3}{|c|}{$\mathrm{N} / \mathrm{A}^{2}$} & $3 / 29 / 78$ & 387 & 95.6 \\
\hline \multicolumn{3}{|c|}{$N / A^{2}$} & \multicolumn{3}{|c|}{$\mathrm{N} / \mathrm{A}^{2}$} & $5 / 8 / 78$ & $516^{1}$ & $\mathrm{~N} / \mathrm{A}^{2}$ \\
\hline $12 / 20 / 78$ & 26 & 92.6 & \multicolumn{3}{|c|}{$\mathrm{N} / \mathrm{A}^{2}$} & $5 / 15 / 78$ & $1,080^{1}$ & $\mathrm{~N}^{2} \mathrm{~A}^{2}$ \\
\hline \multicolumn{3}{|c|}{ N/A ${ }^{2}$} & $6 / 5 / 78$ & 180 & 28.6 & $6 / 26 / 78$ & 810 & 95.6 \\
\hline \multicolumn{3}{|c|}{ N/A ${ }^{2}$} & \multicolumn{3}{|c|}{$\mathrm{N} / \mathrm{A}^{2}$} & $9 / 27 / 78$ & 660 & 95.6 \\
\hline \multicolumn{3}{|c|}{$\mathrm{N} / \mathrm{A}^{2}$} & \multicolumn{3}{|c|}{ N/A ${ }^{2}$} & $12 / 20 / 78$ & 870 & 95.6 \\
\hline $12 / 25 / 79$ & 23 & 92.6 & $12 / 25 / 79$ & 138 & 28.6 & $12 / 25 / 79$ & 192 & 96.6 \\
\hline \multirow{2}{*}{$12 / 16 / 80$} & \multirow{2}{*}{$14^{4}$} & \multirow{2}{*}{92.6} & \multirow{2}{*}{$12 / 16 / 80$} & 136 & 38.6 & \multirow{2}{*}{$12 / 16 / 80$} & \multirow{2}{*}{$222^{4}$} & \multirow{2}{*}{88.6} \\
\hline & & & & $136^{4}$ & 28.6 & & & \\
\hline $12 / 28 / 81$ & 18 & 92.6 & $10 / 28 / 81$ & 159 & 28.6 & $10 / 28 / 81$ & 434 & 87.6 \\
\hline $12 / 15 / 82$ & 22 & 92.6 & $12 / 15 / 81$ & 149 & 27.6 & $12 / 15 / 82$ & 398 & 87.6 \\
\hline $8 / 26 / 83$ & 14 & 93.6 & $8 / 26 / 83$ & 103 & 40.6 & $8 / 26 / 83$ & 126 & 88.6 \\
\hline $9 / 1 / 83$ & 19 & 96.6 & $9 / 1 / 83$ & 164 & 41.6 & $9 / 1 / 83$ & 527 & 86.6 \\
\hline $11 / 18 / 83$ & 9 & 94.6 & $11 / 18 / 83$ & 132 & 40.6 & $11 / 18 / 83$ & 236 & 88.6 \\
\hline $10 / 15 / 84$ & 10 & 94.6 & $10 / 15 / 84$ & 147 & 41.6 & $10 / 15 / 84$ & 400 & 88.6 \\
\hline $9 / 26 / 85$ & 14 & 94.6 & $9 / 26 / 85$ & 122 & 42.6 & $9 / 26 / 85$ & 394 & 89.6 \\
\hline $6 / 20 / 86$ & 16 & 97.6 & $6 / 20 / 86$ & 136 & 41.6 & $6 / 20 / 86$ & 480 & 89.6 \\
\hline
\end{tabular}

Note: ${ }^{1}$ Referenced from WHC-MR-0264

\footnotetext{
${ }^{2}$ N/A: Data not available

${ }^{3}$ New monitoring equipment

${ }^{4}$ New measuring method

${ }^{5}$ Length is distance from the caisson

${ }^{6}$ Referenced from WHC-MR-0250

${ }^{7}$ Referenced from HAN-93855

${ }^{8}$ Referenced from ARH-78 and HAN-98918

${ }^{9}$ Activity measuring instrument repaired which corrected these values from previous readings
} 
RPP-RPT-54912, Rev. 0

\section{APPENDIX D2}

TANK A-105 GROSS GAMMA DRYWELL DATA 
Table D2-1. Tank 241-A-105 Drywell Radioactivity (K counts per minute) (March 1969 to November 1986)

(Drywell Data Sheets Retrieved on March 15, 2011 and SD-WM-TI-356) (1 of 3 sheets)

\begin{tabular}{|c|c|c|c|c|c|c|c|c|c|c|c|c|c|c|c|c|c|c|c|c|c|c|c|c|c|}
\hline \multicolumn{3}{|c|}{ 10-06-09 } & \multicolumn{3}{|c|}{ 10-05-02 } & \multicolumn{3}{|c|}{$10-05-05$} & \multicolumn{3}{|c|}{ 10-05-07 } & \multicolumn{2}{|c|}{$10-05-08$} & \multicolumn{3}{|c|}{ 10-04-04 } & \multicolumn{3}{|c|}{$10-05-09$} & \multicolumn{3}{|c|}{$10-05-10$} & \multicolumn{3}{|c|}{$10-05-12$} \\
\hline Date & $\begin{array}{c}\text { Peak } \\
\text { (K cpm) }\end{array}$ & $\begin{array}{c}\text { Depth } \\
\text { (ft BGS) }\end{array}$ & Date & $\begin{array}{c}\text { Peak } \\
(\mathrm{K} \text { cpm })\end{array}$ & $\begin{array}{l}\text { Depth } \\
\text { (ft BGS) }\end{array}$ & Date & $\begin{array}{c}\text { Peak } \\
\text { (K cpm) }\end{array}$ & $\begin{array}{c}\begin{array}{c}\text { Depth } \\
\text { (ft } \\
\text { BGS) }\end{array} \\
\end{array}$ & Date & $\begin{array}{l}\text { Peak } \\
(\mathbf{K} \\
\text { cpm) }\end{array}$ & $\begin{array}{c}\text { Depth } \\
\text { (ft } \\
\mathbf{B G S})\end{array}$ & Date & \begin{tabular}{|l|l}
$\begin{array}{l}\text { Peak } \\
\text { (K cpm) }\end{array}$ \\
\end{tabular} & Date & $\begin{array}{l}\begin{array}{l}\text { Peak } \\
\text { (K cpm) }\end{array} \\
\end{array}$ & $\begin{array}{c}\begin{array}{c}\text { Depth } \\
\text { (ft } \\
\text { BGS) }\end{array} \\
\end{array}$ & Date & \begin{tabular}{|l|} 
Peak \\
(K \\
( ppm)
\end{tabular} & $\begin{array}{c}\text { Depth } \\
\text { (ft BGS) }\end{array}$ & Date & $\begin{array}{c}\text { Peak } \\
\text { (K cpm) }\end{array}$ & $\begin{array}{c}\text { Depthe } \\
\text { (ft BGS) }\end{array}$ & Date & $\begin{array}{c}\text { Peak } \\
(\mathbf{K} \\
\mathbf{c p m})\end{array}$ & $\begin{array}{c}\text { Depth } \\
\text { (ft BGS) }\end{array}$ \\
\hline \multirow{4}{*}{$1 / 3 / 65$} & 45 & 18 & & \multirow{4}{*}{\multicolumn{2}{|c|}{$N / A^{3}$}} & \multirow{4}{*}{$1 / 3 / 65$} & 10 & 50 & \multirow{4}{*}{\multicolumn{3}{|c|}{$N / A^{3}$}} & \multirow{4}{*}{\multicolumn{2}{|c|}{$N / A^{3}$}} & \multirow{4}{*}{\multicolumn{3}{|c|}{$N / A^{3}$}} & \multirow{4}{*}{\multicolumn{3}{|c|}{$N / A^{3}$}} & \multirow{4}{*}{\multicolumn{3}{|c|}{$N / A^{3}$}} & \multirow{4}{*}{$1 / 3 / 65$} & 250 & 5 \\
\hline & 10 & 50 & & & & & 10 & 70 & & & & & & & & & & & & & & & & 7 & 50 \\
\hline & 10 & 80 & & & & & 56 & 75 & & & & & & & & & & & & & & & & 8 & 70 \\
\hline & 45 & 83 & & & & & & & & & & & & & & & & & & & & & & 110 & 75 \\
\hline & 40 & 20 & & 7 & 50 & & & & & 6 & 50 & & & & & & & 15 & 15 & & 6 & 50 & & & \\
\hline $1 / 7 / 65$ & 6 & 50 & $1 / 7 / 65$ & 8 & 70 & & $\mathrm{~N} / \mathrm{A}^{3}$ & & $1 / 7765$ & 7 & 70 & & $\mathrm{~N} / \mathrm{A}^{3}$ & & $N / \mathrm{A}^{3}$ & & $1 / 7 / 65$ & 6 & 50 & $1 / 7165$ & 6 & 70 & & $\mathrm{~N} / \mathrm{A}^{3}$ & \\
\hline & 7 & 80 & & 40 & 74 & & & & & 21 & 74 & & & & & & & 6 & 70 & & 8 & 74 & & & \\
\hline & 100 & 84 & & & & & & & & & & & & & & & & 7 & 73 & & & & & & \\
\hline & 8 & 17 & & 7 & 70 & & 8 & 70 & & 6 & 70 & & & & & & & 6 & 16 & & 6 & 20 & & 210 & 5 \\
\hline $11 / 3 / 65$ & 45 & 20 & $11 / 3 / 65$ & 39 & 76 & $11 / 3 / 65$ & 62 & 75 & $11 / 3 / 65$ & 8 & 75 & & $\mathrm{~N} / \mathrm{A}^{3}$ & & $\mathrm{~N} / \mathrm{A}^{3}$ & & $1 / 1 / 65$ & 25 & 19 & $11 / 3 / 65$ & 5 & 70 & $11 / 3 / 65$ & 7 & 70 \\
\hline 1. & 8 & 80 & & & & the & & & Heros & & & & & & & & then & 5 & 70 & 1.toros & 22 & 75 & ther & 110 & 75 \\
\hline & 130 & 84 & & & & & & & & & & & & & & & & 9 & 74 & & & & & & \\
\hline & 48 & 20 & & & & & 6 & 50 & & & & & & & & & & & & & & & & 96 & 6 \\
\hline $11 / 12 / 65$ & 7 & 50 & & $N / A^{3}$ & & $11 / 12 / 65$ & 17 & 73 & & $N / A^{3}$ & & & $J / A^{3}$ & & $N / A^{3}$ & & & $N / A^{3}$ & & & $N / A^{3}$ & & $11 / 12 / 65$ & 6 & 50 \\
\hline & 8 & 82 & & & & & 66 & 75 & & & & & & & & & & & & & & & & 9 & 74 \\
\hline & 150 & 84 & & & & & & & & & & & & & & & & & & & & & & 130 & 76 \\
\hline & 7 & 50 & & & & & 6 & 50 & & & & & & & & & & & & & & & & 200 & 5 \\
\hline $11 / 18 / 65$ & 6 & 80 & & $\mathrm{~N} / \mathrm{A}^{3}$ & & $11 / 18 / 65$ & 10 & 73 & & $\mathrm{~N} / \mathrm{A}^{3}$ & & & $\mathrm{~N} / \mathrm{A}^{3}$ & & $N / \mathrm{A}^{3}$ & & & $\mathrm{~N} / \mathrm{A}^{3}$ & & & $N / \mathrm{A}^{3}$ & & $11 / 18 / 65$ & 7 & 50 \\
\hline & 110 & 84 & & & & & 60 & 76 & & & & & & & & & & & & & & & & 7 & 70 \\
\hline & & & & & & & & & & & & & & & & & & & & & & & & 110 & 76 \\
\hline & 6 & 16 & & 6 & 25 & & 7 & 25 & & 6 & 25 & & & & & & & 6 & 25 & & 5 & 25 & & 250 & 6 \\
\hline & 45 & 19 & & 8 & 50 & & 6 & 50 & & 7 & 50 & & & & & & & 7 & 50 & & 5 & 50 & & 7 & 25 \\
\hline $11 / 22 / 65$ & 7 & 25 & $11 / 22 / 65$ & 9 & 74 & $11 / 22 / 65$ & 10 & 72 & $11 / 22 / 65$ & 9 & 75 & & $V / A^{3}$ & & $N / A^{3}$ & & $11 / 22 / 65$ & 5 & 70 & $11 / 22 / 65$ & 12 & 75 & $11 / 22 / 65$ & 6 & 50 \\
\hline & 6 & 50 & & 54 & 77 & & 22 & 74 & & 32 & 76 & & & & & & & & & & & & & 10 & 73 \\
\hline & 8.5 & 82 & & & & & 62 & 76 & & & & & & & & & & & & & & & & 32 & 75 \\
\hline & 150 & 84 & & & & & & & & & & & & & & & & & & & & & & 120 & 77 \\
\hline & 40 & 19 & & & & & 9 & 50 & & & & & & & & & & & & & & & & 220 & 6 \\
\hline $1 / 21 / 66$ & 9 & 50 & & $\mathrm{~N} / \mathrm{A}^{3}$ & & $1 / 21 / 66$ & 10 & 70 & & $\mathrm{~N} / \mathrm{A}^{3}$ & & & $\mathrm{~N} / \mathrm{A}^{3}$ & & $\mathrm{~N} / \mathrm{A}^{3}$ & & & $\mathrm{~N} / \mathrm{A}^{3}$ & & & $\mathrm{~N} / \mathrm{A}^{3}$ & & $1 / 21 / 66$ & 8 & 50 \\
\hline & 10 & 80 & & & & & 60 & 76 & & & & & & & & & & & & & & & & 10 & 70 \\
\hline & 36 & 83 & & & & & & & & & & & & & & & & & & & & & & 68 & 76 \\
\hline & 40 & 19 & & 7 & 50 & & 8 & 50 & & 6 & 50 & & & & & & & 15 & 15 & & 6 & 50 & & 230 & 5 \\
\hline $1207 / 66$ & 10 & 50 & $1207 / 66$ & 8 & 70 & 127166 & 10 & 70 & 127166 & 7 & 70 & & $I / A^{3}$ & & $N / A^{3}$ & & $1 / 27 / 66$ & 6 & 50 & 1207166 & 6 & 70 & $127 / 66$ & 10 & 50 \\
\hline $11 / 2100$ & 12 & 82 & $11 / 2100$ & 40 & 74 & $1 / 2 / 100$ & 64 & 75 & 1127100 & 22 & 74 & & $\sqrt{N A}$ & & & & $1 / 27100$ & 6 & 70 & 1127100 & 8 & 74 & 1127100 & 10 & 70 \\
\hline & 80 & 84 & & & & & & & & & & & & & & & & 7 & 73 & & & & & 110 & 76 \\
\hline
\end{tabular}


Table D2-1. Tank 241-A-105 Drywell Radioactivity (K counts per minute) (March 1969 to November 1986)

(Drywell Data Sheets Retrieved on March 15, 2011 and SD-WM-TI-356) (2 of 3 sheets)

\begin{tabular}{|c|c|c|c|c|c|c|c|c|c|c|c|c|c|c|c|c|c|c|c|c|c|c|c|c|c|}
\hline \multicolumn{3}{|c|}{ 10-06-09 } & \multicolumn{3}{|c|}{$10-05-02$} & \multicolumn{3}{|c|}{$10-05-05$} & \multicolumn{3}{|c|}{ 10-05-07 } & \multicolumn{2}{|c|}{$10-05-08$} & \multicolumn{3}{|c|}{$10-04-04$} & \multicolumn{3}{|c|}{$10-05-09$} & \multicolumn{3}{|c|}{$10-05-10$} & \multicolumn{3}{|c|}{$10-05-12$} \\
\hline Date & $\begin{array}{c}\text { Peak } \\
\text { (K cpm) }\end{array}$ & $\begin{array}{c}\text { Depth } \\
\text { (ft BGS) }\end{array}$ & Date & $\begin{array}{c}\text { Peak } \\
\text { (K c cpm) }\end{array}$ & $\begin{array}{l}\text { Depth } \\
\text { (ft BGS) }\end{array}$ & Date & $\begin{array}{c}\text { Peak } \\
\text { (K cpm) }\end{array}$ & $\begin{array}{c}\text { Depth } \\
\text { (ft } \\
\text { BGS) }\end{array}$ & Date & $\begin{array}{l}\text { Peak } \\
(\mathbf{K} \\
\mathrm{cpm})\end{array}$ & $\begin{array}{c}\text { Depth } \\
\text { (ft } \\
\text { BGS) }\end{array}$ & Date & $\begin{array}{l}\text { Peak } \\
\text { (K cpm) }\end{array}$ & Date & $\begin{array}{l}\text { Peak } \\
\text { (K cpm) }\end{array}$ & $\begin{array}{c}\text { Deptstit } \\
\text { (ft } \\
\text { BGS) }\end{array}$ & Date & $\begin{array}{l}\text { Peak } \\
(\mathbf{K} \\
\text { cpm) }\end{array}$ & $\begin{array}{c}\text { Depth } \\
\text { (ft BGS) }\end{array}$ & Date & $\begin{array}{c}\text { Peak } \\
(\mathbf{K ~ c p m})\end{array}$ & $\begin{array}{c}\text { Depth } \\
\text { (ft BGS) }\end{array}$ & Date & $\begin{array}{c}\text { Peak } \\
(\mathbf{K} \\
\mathrm{cpm}) \\
\end{array}$ & $\begin{array}{c}\text { Depth } \\
\text { (ft BGS) }\end{array}$ \\
\hline \multirow{4}{*}{ 2/4/66 } & 40 & 19 & & \multirow{4}{*}{\multicolumn{2}{|c|}{$N / A^{3}$}} & \multirow{4}{*}{ 2/4/66 } & 7 & 50 & \multirow{4}{*}{\multicolumn{3}{|c|}{$N / A^{3}$}} & \multirow{4}{*}{\multicolumn{2}{|c|}{$N / A^{3}$}} & \multirow{4}{*}{\multicolumn{3}{|c|}{$N / A^{3}$}} & \multirow{4}{*}{\multicolumn{3}{|c|}{$N / A^{3}$}} & \multirow{4}{*}{\multicolumn{3}{|c|}{$N / A^{3}$}} & & 200 & 6 \\
\hline & 9 & 50 & & & & & 10 & 70 & & & & & & & & & & & & & & & $2 / 4 / 66$ & 7 & 50 \\
\hline & 10 & 80 & & & & & 63 & 75 & & & & & & & & & & & & & & & & 8 & 70 \\
\hline & 52 & 84 & & & & & & & & & & & & & & & & & & & & & & 100 & 76 \\
\hline & 8 & 50 & & & & & 8 & 50 & & & & & & & & & & & & & & & & 15 & 6 \\
\hline $5 / 12 / 66$ & 8 & 80 & & $N / A^{3}$ & & $5 / 12 / 66$ & 8 & 70 & & $N / A^{3}$ & & & & & $N / A^{3}$ & & & $\mathrm{~N} / \mathrm{A}^{3}$ & & & $N / A^{3}$ & & $5 / 12 / 66$ & 8 & 70 \\
\hline & 130 & 83 & & & & & 50 & 74 & & & & & & & & & & & & & & & & 58 & 76 \\
\hline & 23 & 17 & & & & & 8 & 50 & & & & & & & & & & & & & & & & 130 & 6 \\
\hline 5120166 & 8 & 50 & & $N / A^{3}$ & & $5 / 20 / 66$ & 8 & 70 & & $N / \mathrm{A}^{3}$ & & & & & $N / A^{3}$ & & & $N / \mathrm{A}^{3}$ & & & $N / 3^{3}$ & & 520166 & 8 & 70 \\
\hline SILVI/100 & 8 & 80 & & & & JiLOVOOO & 50 & 73 & & & & & & & & & & & & & N/A & & $3 / 20100$ & 88 & 76 \\
\hline & 120 & 83 & & & & & & & & & & & & & & & & & & & & & & & \\
\hline & 25 & 19 & & 8 & 50 & & 8 & 50 & & 8 & 50 & & & & & & & 8 & 50 & & 8 & 50 & & 120 & 5 \\
\hline 5125166 & 8 & 50 & 5125166 & 8 & 70 & $5 / 25 / 66$ & 8 & 70 & $5 / 25 / 66$ & 8 & 70 & & & & $\mathrm{~N} / \mathrm{A}^{3}$ & & $5 / 26166$ & 8 & 70 & $5 / 25 / 66$ & 8 & 70 & $5 / 25 / 66$ & 8 & 50 \\
\hline S/LF/100 & 8 & 80 & S/25/100 & 50 & 76 & $3 / 25 / 100$ & 50 & 76 & & 30 & 75 & & & & & & & 60 & 75 & & 20 & 75 & & 8 & 70 \\
\hline & 120 & 83 & & & & & & & & & & & & & & & & & & & & & & 90 & 76 \\
\hline & 24 & 18 & & 8 & 50 & & 8 & 50 & & 8 & 50 & & & & & & & 8 & 50 & & 8 & 50 & & 64 & 6 \\
\hline $8 / 26166$ & 8 & 50 & $8 / 26 / 66$ & 8 & 73 & $8 / 26 / 66$ & 8 & 70 & $8 / 26 / 66$ & 8 & 73 & & & & $\mathrm{~N} / \mathrm{A}^{3}$ & & $8 / 26166$ & 8 & 70 & $8 / 26 / 166$ & 8 & 70 & $8 / 26 / 66$ & 8 & 56 \\
\hline & 8 & 80 & & 60 & 74 & $8 / 20 / 00$ & 52 & 74 & & 35 & 75 & & & & N/A & & $8 / 20100$ & 15 & 74 & $8 / 20100$ & 20 & 75 & $8 / 20 / 100$ & 8 & 70 \\
\hline & 120 & 84 & & & & & & & & & & & & & & & & & & & & & & 100 & 76 \\
\hline 9/13/72 & $<6$ & $\mathrm{~N} / \mathrm{A}^{3}$ & 9/13/72 & 12 & $\mathrm{~N} / \mathrm{A}^{3}$ & $9 / 13 / 72$ & $<6$ & $N / A^{3}$ & $9 / 13 / 72$ & $<6$ & $\mathrm{~N} / \mathrm{A}^{3}$ & 9/13/72 & $<6$ & 9/13/72 & $<6$ & $N / A^{3}$ & 9/13/72 & $<6$ & $\mathrm{~N} / \mathrm{A}^{3}$ & 9/13/72 & 28 & 60 & 9/13/72 & 9 & 76 \\
\hline & $N / A^{3}$ & & & $N / A^{3}$ & & $4 / 6 / 72$ & $<6$ & $N / A^{3}$ & & $\mathrm{~N} / \mathrm{A}^{3}$ & & & & & $N / A^{3}$ & & & $\mathrm{~N} / \mathrm{A}^{3}$ & & & $N / A^{3}$ & & & $N / A^{3}$ & \\
\hline & $N / A^{3}$ & & $5 / 1 / 73$ & 12 & $N / A^{3}$ & & $N / A^{3}$ & & & $\mathrm{~N} / \mathrm{A}^{3}$ & & & & & $\mathrm{~N} / \mathrm{A}^{3}$ & & & $N / A^{3}$ & & & $\mathrm{~N} / \mathrm{A}^{3}$ & & & $N / \mathrm{A}^{3}$ & \\
\hline & $N / A^{3}$ & & $10 / 8 / 73$ & 12 & $N / A^{3}$ & & $\mathrm{~N} / \mathrm{A}^{3}$ & & & $\mathrm{~N} / \mathrm{A}^{3}$ & & & & & $\mathrm{~N} / \mathrm{A}^{3}$ & & & $\mathrm{~N} / \mathrm{A}^{3}$ & & $10 / 22 / 73$ & 19 & 59 & & $\mathrm{~N} / \mathrm{A}^{3}$ & \\
\hline & $N / A^{3}$ & & $11 / 12 / 73$ & 12 & $N / A^{3}$ & & $N / A^{3}$ & & & $\mathrm{~N} / \mathrm{A}^{3}$ & & & & & $\mathrm{~N} / \mathrm{A}^{3}$ & & & $N / A^{3}$ & & & $\mathrm{~N} / \mathrm{A}^{3}$ & & & $N / A^{3}$ & \\
\hline $4 / 4 / 74$ & $<6$ & $N / A^{3}$ & $4 / 16 / 74$ & 12 & $\mathrm{~N} / \mathrm{A}^{3}$ & & $N / A^{3}$ & & $4 / 6 / 74$ & $<6$ & $\mathrm{~N} / \mathrm{A}^{3}$ & $4 / 6 / 74$ & $<6$ & $4 / 6 / 74$ & $<6$ & $\mathrm{~N} / \mathrm{A}^{3}$ & $4 / 6 / 74$ & $<6$ & $N / A^{3}$ & $4 / 10 / 74$ & 11 & 61 & 4/10/74 & $<6$ & $\mathrm{~N} / \mathrm{A}^{3}$ \\
\hline & $N / A^{3}$ & & $1 / 20 / 75$ & $101^{2}$ & 73 & $7 / 14 / 75$ & $<3$ & $\mathrm{~N} / \mathrm{A}^{3}$ & $7 / 14 / 75$ & $<3$ & $\mathrm{~N} / \mathrm{A}^{3}$ & $7 / 14 / 75$ & $<3$ & 7/14/75 & $<3$ & $\mathrm{~N} / \mathrm{A}^{3}$ & 7/14/74 & $<3$ & $N / A^{3}$ & $7 / 14 / 75$ & 6 & 60 & $7 / 14 / 75$ & $<3$ & $\mathrm{~N} / \mathrm{A}^{3}$ \\
\hline $7 / 14 / 75$ & $<3$ & $\mathrm{~N} / \mathrm{A}^{3}$ & 777775 & 79 & 73 & & $N / A^{3}$ & & & $\mathrm{~N} / \mathrm{A}^{3}$ & & & $\mathrm{~A}^{3}$ & & $\mathrm{~N} / \mathrm{A}^{3}$ & & & $\mathrm{~N} / \mathrm{A}^{3}$ & & & $\mathrm{~N} / \mathrm{A}^{3}$ & & & $N / \mathrm{A}^{3}$ & \\
\hline $1 / 5 / 76$ & $<3$ & $\mathrm{~N} / \mathrm{A}^{3}$ & $1 / 5 / 76$ & 60 & 70 & $1 / 5 / 76$ & $<3$ & $N / A^{3}$ & $1 / 5 / 76$ & $<3$ & $\mathrm{~N} / \mathrm{A}^{3}$ & $1 / 5 / 76$ & $<3$ & $1 / 5 / 76$ & $<3$ & $N / A^{3}$ & $1 / 5 / 76$ & $<3$ & $N / A^{3}$ & $1 / 5 / 76$ & 5 & 56 & $1 / 5 / 76$ & $<3$ & $N / A^{3}$ \\
\hline & $N / A^{3}$ & & $6 / 1776$ & 45 & 71 & & $\mathrm{~N} / \mathrm{A}^{3}$ & & & $\mathrm{~N} / \mathrm{A}^{3}$ & & & $4^{3}$ & & $\mathrm{~N} / \mathrm{A}^{3}$ & & & $\mathrm{~N} / \mathrm{A}^{3}$ & & & $\mathrm{~N} / \mathrm{A}^{3}$ & & & $N / \mathrm{A}^{3}$ & \\
\hline $12 / 6 / 76$ & $<3$ & $\mathrm{~N} / \mathrm{A}^{3}$ & $12 / 6 / 76$ & 32 & 71 & $12 / 6 / 76$ & $<3$ & $N / A^{3}$ & $12 / 6 / 76$ & $<3$ & $N / A^{3}$ & $12 / 6 / 76$ & $<3$ & $11 / 22 / 76$ & $<3$ & $N / A^{3}$ & $12 / 6 / 76$ & $<3$ & $N / A^{3}$ & $12 / 6 / 76$ & 3 & 59 & $12 / 6 / 76$ & $<3$ & $N / A^{3}$ \\
\hline $6 / 13 / 77$ & $<3$ & $N / A^{3}$ & $6 / 27 / 77$ & 21 & 71 & $6 / 13 / 77$ & $<3$ & $N / A^{3}$ & $6 / 13 / 77$ & $<3$ & $N / A^{3}$ & $6 / 13 / 77$ & $<3$ & 6/13/77 & $<3$ & $N / A^{3}$ & 6/15/77 & $<3$ & $N / A^{3}$ & $3 / 14 / 77$ & 3 & 61 & 6/13/77 & $<3$ & $N / A^{3}$ \\
\hline & $N / A^{3}$ & & & $\mathrm{~N} / \mathrm{A}^{3}$ & & & $\mathrm{~N} / \mathrm{A}^{3}$ & & & $N / A^{3}$ & & & $4^{3}$ & & $\mathrm{~N} / \mathrm{A}^{3}$ & & & $N / A^{3}$ & & $811 / 77$ & 3 & 58 & & $N / A^{3}$ & \\
\hline $11 / 28 / 77$ & $<3$ & $N / A^{3}$ & $11 / 28 / 77$ & 18 & 71 & $11 / 28 / 77$ & $<3$ & $N / A^{3}$ & $11 / 28 / 77$ & $<3$ & $N / A^{3}$ & $11 / 28 / 77$ & $<3$ & $11 / 28 / 77$ & $<3$ & $N / A^{3}$ & $11 / 28 / 77$ & $<3$ & $N / A^{3}$ & $11 / 28 / 77$ & $<3$ & $N / A^{3}$ & $11 / 28 / 77$ & $<3$ & $N / A^{3}$ \\
\hline $7 / 17778$ & $<3$ & $\mathrm{~N} / \mathrm{A}^{3}$ & 7/10/78 & 11 & 71 & & $N / A^{3}$ & & & $\mathrm{~N} / \mathrm{A}^{3}$ & & & & & $\mathrm{~N} / \mathrm{A}^{3}$ & & & $\mathrm{~N} / \mathrm{A}^{3}$ & & & $N / A^{3}$ & & & $\mathrm{~N} / \mathrm{A}^{3}$ & \\
\hline & $N / A^{3}$ & & $7 / 21 / 78$ & 91 & 71 & & $N / A^{3}$ & & & $\mathrm{~N} / \mathrm{A}^{3}$ & & & & & $\mathrm{~N} / \mathrm{A}^{3}$ & & & $\mathrm{~N} / \mathrm{A}^{3}$ & & & $N / A^{3}$ & & & $\mathrm{~N} / \mathrm{A}^{3}$ & \\
\hline & $N / \mathrm{A}^{3}$ & & 9/25/78 & 41 & 71 & & $\mathrm{~N} / \mathrm{A}^{3}$ & & & $\mathrm{~N} / \mathrm{A}^{3}$ & & & $4^{3}$ & & $\mathrm{~N} / \mathrm{A}^{3}$ & & & $N / A^{3}$ & & 811878 & 8 & 74 & & $N / A^{3}$ & \\
\hline $12218 / 78$ & $<3$ & $\mathrm{~N} / \mathrm{A}^{3}$ & $12 / 19 / 78$ & 26 & 71 & $12 / 18 / 78$ & $<3$ & $\mathrm{~N} / \mathrm{A}^{3}$ & $12 / 18 / 78$ & $<3$ & $\mathrm{~N} / \mathrm{A}^{3}$ & $12 / 19 / 78$ & $<3$ & $12 / 19 / 78$ & $<3$ & $\mathrm{~N} / \mathrm{A}^{3}$ & \begin{tabular}{|l|l|}
$12 / 19 / 78$ \\
\end{tabular} & $<3$ & $N / A^{3}$ & $12 / 18 / 78$ & 9 & 76 & $12 / 19 / 78$ & $<3$ & $\mathrm{~N} / \mathrm{A}^{3}$ \\
\hline
\end{tabular}


Table D2-1. Tank 241-A-105 Drywell Radioactivity (K counts per minute) (March 1969 to November 1986) (Drywell Data Sheets Retrieved on March 15, 2011 and SD-WM-TI-356) (3 of 3 sheets) ${ }^{1}$

\begin{tabular}{|c|c|c|c|c|c|c|c|c|c|c|c|c|c|c|c|c|c|c|c|c|c|c|c|c|c|}
\hline \multicolumn{3}{|c|}{$10-06-09$} & \multicolumn{3}{|c|}{$10-05-02$} & \multicolumn{3}{|c|}{$10-05-05$} & \multicolumn{3}{|c|}{$10-05-07$} & \multicolumn{2}{|c|}{$10-05-08$} & \multicolumn{3}{|c|}{$10-04-04$} & \multicolumn{3}{|c|}{ 10-05-09 } & \multicolumn{3}{|c|}{$10-05-10$} & \multicolumn{3}{|c|}{$10-05-12$} \\
\hline Date & $\begin{array}{c}\text { Peak } \\
\text { (K cpm) }\end{array}$ & $\begin{array}{c}\text { Depth } \\
\text { (ft BGS) }\end{array}$ & Date & $\begin{array}{c}\text { Peak } \\
\text { (K cpm) }\end{array}$ & \begin{tabular}{|l} 
Depth \\
(ft BGS)
\end{tabular} & Date & $\begin{array}{c}\text { Peak } \\
\text { (K cpm) }\end{array}$ & $\begin{array}{l}\text { Depth } \\
\text { (ft } \\
\text { BGS) }\end{array}$ & Date & $\begin{array}{l}\text { Peak } \\
(\mathbf{K} \\
\mathrm{cpm})\end{array}$ & $\begin{array}{c}\text { Deptet } \\
\text { fot } \\
\text { BGS })\end{array}$ & Date & \begin{tabular}{|l} 
Peak \\
(K cpm)
\end{tabular} & Date & $\begin{array}{l}\text { Peak } \\
\text { (K cpm) }\end{array}$ & $\begin{array}{c}\text { Depth } \\
\text { (ft } \\
\text { BGS) }\end{array}$ & Date & 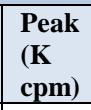 & $\begin{array}{c}\text { Depth } \\
\text { (ft BGS) }\end{array}$ & Date & $\begin{array}{c}\text { Peak } \\
\text { (K cpm) }\end{array}$ & $\begin{array}{c}\text { Depth } \\
\text { (ft BGS) }\end{array}$ & Date & $\begin{array}{l}\text { Peak } \\
\text { (KK } \\
\text { cpm }\end{array}$ & $\begin{array}{c}\text { Depth } \\
\text { (ft BGS) }\end{array}$ \\
\hline $12 / 3 / 79$ & $<3$ & $\mathrm{~N} / \mathrm{A}^{3}$ & $12 / 31 / 79$ & 12 & 71 & $12 / 19 / 79$ & $<3$ & $N / A^{3}$ & $12 / 19 / 79$ & $<3$ & $\mathrm{~N} / \mathrm{A}^{3}$ & $12 / 19 / 79$ & $<3$ & $12 / 19 / 79$ & $<3$ & $N / A^{3}$ & 12/19/79 & $<3$ & $N / A^{3}$ & $12 / 3 / 79$ & 8 & 75 & $12 / 19 / 79$ & $<3$ & $N / A^{3}$ \\
\hline $12 / 16 / 80$ & $<3$ & $N / A^{3}$ & $12 / 15 / 80$ & 5 & 71 & $12 / 15 / 80$ & $<3$ & $N / A^{3}$ & $12 / 15 / 80$ & $<3$ & $\mathrm{~N} / \mathrm{A}^{3}$ & $12 / 15 / 80$ & $<3$ & $12 / 15 / 80$ & $<3$ & $N / A^{3}$ & $12 / 15 / 80$ & $<3$ & $N / A^{3}$ & $12 / 15 / 80$ & 9 & 75 & $12 / 15 / 80$ & $<3$ & $N / A^{3}$ \\
\hline $12 / 14 / 81$ & $<3$ & $N / A^{3}$ & $10 / 19 / 81$ & 4 & 71 & $10 / 19 / 81$ & $<3$ & $N / A^{3}$ & $10 / 19 / 81$ & $<3$ & $\mathrm{~N} / \mathrm{A}^{3}$ & 10/19/81 & $<3$ & 10/19/81 & $<3$ & $N / A^{3}$ & $\mid 10 / 19 / 81$ & $<3$ & $N / A^{3}$ & $10 / 19 / 81$ & 8 & 76 & $10 / 19 / 81$ & $<3$ & $N / A^{3}$ \\
\hline $11 / 29 / 82$ & $<3$ & $N / A^{3}$ & $12 / 13 / 82$ & 3 & 71 & $12 / 13 / 82$ & $<3$ & $\mathrm{~N} / \mathrm{A}^{3}$ & $12 / 13 / 82$ & $<3$ & $\mathrm{~N} / \mathrm{A}^{3}$ & $12 / 13 / 82$ & $<3$ & $12 / 13 / 82$ & $<3$ & $N / A^{3}$ & $12 / 13 / 82$ & $<3$ & $\mathrm{~N} / \mathrm{A}^{3}$ & $12 / 13 / 82$ & 9 & 77 & $12 / 13 / 82$ & $<3$ & $N / A^{3}$ \\
\hline $11 / 15 / 83$ & $<3$ & $N / A^{3}$ & $11 / 15 / 83$ & 2 & 71 & $11 / 15 / 83$ & $<3$ & $\mathrm{~N} / \mathrm{A}^{3}$ & $11 / 15 / 83$ & $<3$ & $\mathrm{~N} / \mathrm{A}^{3}$ & $11 / 15 / 83$ & $<3$ & $11 / 15 / 83$ & $<3$ & $\mathrm{~N} / \mathrm{A}^{3}$ & $111 / 15 / 83$ & $<3$ & $\mathrm{~N} / \mathrm{A}^{3}$ & $11 / 15 / 83$ & 7 & 78 & $11 / 15 / 83$ & $<3$ & $N / A^{3}$ \\
\hline $10 / 17 / 84$ & $<3$ & $N / A^{3}$ & $10 / 17 / 84$ & 2 & 71 & $10 / 17 / 84$ & $<3$ & $N / A^{3}$ & $10 / 17 / 84$ & $<3$ & $\mathrm{~N} / \mathrm{A}^{3}$ & $10 / 17 / 84$ & $<3$ & $10 / 15 / 84$ & $<3$ & $N / A^{3}$ & $10 / 17 / 84$ & $<3$ & $N / A^{3}$ & $10 / 17 / 84$ & 7 & 78 & $10 / 17 / 84$ & $<3$ & $N / A^{3}$ \\
\hline 9/16/85 & $<3$ & $N / A^{3}$ & $9 / 16 / 85$ & 2 & 71 & $9 / 16 / 85$ & $<3$ & $N / A^{3}$ & $9 / 16 / 86$ & $<3$ & $N / A^{3}$ & 9/16/85 & $<3$ & 9/20/85 & $<3$ & $N / A^{3}$ & 9/16/85 & $<3$ & $N / A^{3}$ & $9 / 16 / 85$ & 8 & 79 & $9 / 16 / 85$ & $<3$ & $N / A^{3}$ \\
\hline $11 / 13 / 86$ & $<3$ & $\mathrm{~N} / \mathrm{A}^{3}$ & $11 / 13 / 86$ & 2 & 71 & $11 / 13 / 86$ & $<3$ & $N / A^{3}$ & $11 / 13 / 86$ & $<3$ & $\mathrm{~N} / \mathrm{A}^{3}$ & $11 / 13 / 86$ & $<3$ & $11 / 13 / 86$ & $<3$ & $N / A^{3}$ & $11 / 13 / 86$ & $<3$ & $N / A^{3}$ & $11 / 13 / 86$ & 8 & 79 & $11 / 13 / 86$ & $<3$ & $\mathrm{~N} / \mathrm{A}^{3}$ \\
\hline
\end{tabular}

Note: III If Depths were not available, the column was omitted from the table

New Probe
'N/A: Data not available 
RPP-RPT-54912, Rev. 0

\subsection{CONCLUSIONS}

Five conditions may have contributed to A Farm tank liner failure including thermal conditions, tank design, bulging, chemistry- corrosion and tank construction conditions. The A Farm tanks continued with the same basic design features as the 241-SX Farm with the fillet welded orthogonal intersection between the bottom and sidewall, less rigorous weld inspection testing and partial asphaltic membrane waterproofing. The A Farm tanks had a flat tank bottom vice the $3.3 \%$ sloped 241-SX Farm tank bottoms.

No tank bottom bulging was reported in tank A-104, however ALC guy rods had become detached which is a possible indicator of bulging. Tank A-104 was preheated at $158^{\circ} \mathrm{F}$ for five months but the temperature rate of rise with initial transfer of waste is not available. It is therefore unknown if any water remaining in the grout was removed or upon heating may have increased the vapor pressure under the tank bottom to a point that resulted in a bulge and weakening of the tank bottom steel.

Tank A-105 was reported to have been preheated up to $\sim 115^{\circ} \mathrm{F}$; however, there were indications in September 1963 of possible initial bulging of the tank A-105 bottom with large fluctuations in the liquid level including increases up to 12 -in equivalent to a $33 \mathrm{kgal}$ volume increase. The tank was pumped to 10-in of liquid which if there was any remaining water in the grout could have resulted in vapor pressure under the bottom liner overcoming the hydrostatic pressure for a period of time resulting in cracks in the bottom liner. Moisture could then have been transferred to the grout through cracks in the liner which re-sealed as waste was added to the tank. PUREX HLW continued to be accumulated up to an equivalent 11,000 tons of uranium production. At that point a steam eruption bulged the tank bottom $81 / 2-\mathrm{ft}$ resulting in a separation of the wall liner from the bottom of the tank.

Corrosive conditions in tank A-104 may have existed during a total of $~ 4$ years of water storage. The storage in tank A-104 of PSS for three years would have created an environment conducive to SCC based on flowsheet conditions. Tank A-105 does not appear to have been exposed to corrosive waste storage; however, water of unknown quality was stored in the tank from 1955 1962 prior to receiving waste.

The A Farm tank construction temperature conditions were not as severe as experienced during 241-SX Farm construction or even during 241-BY and 241-TY Farm construction. There were, however, at least four instances where the temperature dropped below the ductile-to-brittle transition temperature of $18^{\circ} \mathrm{F}$ which could have caused fissures in the steel liner should an impact occur. A contribution to eventual failure of the two tanks is considered unlikely.

It is possible that no one characteristic of the A Farm leaking tanks in isolation from the others have resulted in failure. However, thermal conditions appear to play a primary role with tank design being a contributing factor as well as liquid level control in the case of tank A-105. All or combinations of these characteristics resulted in bulging of the tank liner which in the case of tank A-105 set up possible conditions for the steam eruption. Corrosion and tank constructions conditions could be secondary contributors to liner failure. 
The A Farm leaking tank information (see Table 6-1) was compared to the sound A Farm tanks (see Table 6-2) where similar information was available. All of the A Farm tanks were filled with 6-in of water initially and some contained water for several years before waste was first transferred to the tank. No single design or operating characteristic is highly correlated with the failure of tanks A-104 and A-105. 
RPP-RPT-54912, Rev. 0

Table 6-1. A Farm Leaking Tanks

\begin{tabular}{|c|c|c|c|c|c|c|c|c|c|c|c|c|c|c|c|}
\hline \multirow[b]{2}{*}{$\begin{array}{l}\text { Leakin } \\
\text { g Tank }\end{array}$} & \multicolumn{4}{|c|}{ Initial Waste Details } & \multicolumn{2}{|c|}{ Leak Status } & \multicolumn{2}{|c|}{ Water Addition } & \multicolumn{2}{|c|}{ Evidence of a Bulging Liner } & \multicolumn{5}{|c|}{ Thermal Conditions } \\
\hline & First Filled & First Boiling & Waste Type & $\begin{array}{c}\text { Tank } \\
\text { Pre-heated }\end{array}$ & Leak Detected & $\begin{array}{l}\text { Indication } \\
\text { of leak }\end{array}$ & Water added & $\begin{array}{c}\text { Duration of } \\
\text { Water Storage }\end{array}$ & Bulge Present & Failed ALCs & Rate of Rise & Max Temp & $\begin{array}{c}\text { Temp } \\
\text { Duration }\end{array}$ & Bumping & $\underset{\text { Mressurization }}{\text { Maximum }}$ \\
\hline A-104 & $8 / 9 / 1958^{1}$ & August $1959^{1}$ & $\begin{array}{c}\text { P, OWW, } \\
\text { AR, B, PSS }\end{array}$ & - & March 1975 & Laterals & $\begin{array}{c}-1 / 24 / 1956 \text { to Aug. } 1958 \\
-1969-1972^{6}\end{array}$ & $\begin{array}{l}\sim 32 \text { months } \\
\sim 2 \text { years }\end{array}$ & $\mathrm{No}^{4}$ & Yes & $\begin{array}{c}4.9^{\circ} \mathrm{F} / \mathrm{day}^{7} \\
1 / 2 / 1963 \text { to } \\
2 / 6 / 1963\end{array}$ & $\begin{array}{l}437^{\circ} \mathrm{F} \\
\text { Feb. } 1963\end{array}$ & $\begin{array}{l}17 \text { months } \\
>300^{\circ} \mathrm{F}\end{array}$ & - & - \\
\hline A-105 & May $1962^{2}$ & $3 / 5 / 1963^{3}$ & $\mathrm{P}$ & $\sim 115^{\circ} \mathrm{F}^{2}$ & $\begin{array}{l}\text { Nov. } 1963 \\
\text { March } 1965\end{array}$ & Laterals & 1955-1962 & $\sim 7$ years & $\begin{array}{c}\text { Yes- } 8.5 \mathrm{ft} \\
\text { with liner tear } \\
\text { from sidewall }^{3}\end{array}$ & Yes & $\begin{array}{c}3.3^{\circ} \mathrm{F} / \mathrm{day}^{7} \\
1 / 29 / 1963 \text { to } \\
3 / 1 / 1963\end{array}$ & $\begin{array}{c}285^{\circ} \mathrm{F} \\
\text { Jan. } 1965\end{array}$ & $\begin{array}{c}10 \text { months } \\
>250^{\circ} \mathrm{F}\end{array}$ & $\begin{array}{l}\text { Yes- Jan. } \\
1965^{5}\end{array}$ & - \\
\hline
\end{tabular}

Note: Reference HW-41791 Pt 1, PUREX Waste Storage. Part 1-241-A Waste Storage Facilities 3/7/56 General Electric, States that 6-in of water was added to all A Farm tanks 1/24/56.
Where dashes are used in the cell, information was not known or not available. Where dashes are used in the cell, information was not known or not av

2 RL-Temp Plots (see Figure 4-2)
3 Reference ARH-78 and TRAC-0022

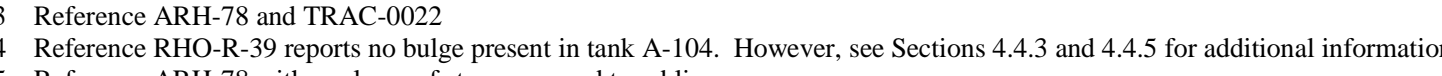

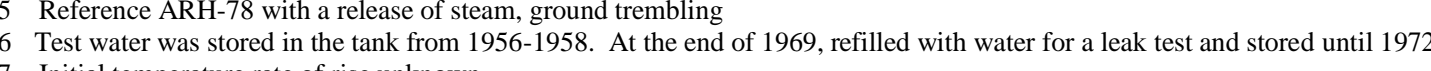

7 Initial temperature rate of rise unknown

Table 6-2. A Farm Sound Tanks

\begin{tabular}{|c|c|c|c|c|c|c|c|c|c|c|c|c|c|c|c|}
\hline \multirow[b]{2}{*}{$\begin{array}{c}\text { Sound } \\
\text { Tank }\end{array}$} & \multicolumn{4}{|c|}{ Initial Waste Details } & \multicolumn{2}{|c|}{ Leak Status } & \multicolumn{2}{|c|}{ Water Addition } & \multicolumn{2}{|c|}{ Evidence of a Bulging Liner } & \multicolumn{5}{|c|}{ Thermal Conditions } \\
\hline & First Filled & $\begin{array}{c}\text { First } \\
\text { Boiling }\end{array}$ & Waste Type & $\begin{array}{c}\text { Tank } \\
\text { Pre-heated }\end{array}$ & Leak Detected & $\begin{array}{l}\text { Indication } \\
\text { of leak }\end{array}$ & Water added & $\begin{array}{l}\text { Duration of } \\
\text { Water Storage }\end{array}$ & Bulge Present & Failed ALCs & Rate of Rise & Max Temp & $\begin{array}{c}\text { Temp } \\
\text { Duration }\end{array}$ & Bumping & $\underset{\text { pressurization }}{\text { Maximum }}$ \\
\hline A-101 & 1/24/1956 & 7/16/1957 & $\begin{array}{l}\text { P, OWW, B, } \\
\text { PL, RESD }\end{array}$ & $\sim 144^{\circ} \mathrm{F}$ & No & No & $1 / 24 / 1956$ & $<1$ month & $\mathrm{No}^{2}$ & Yes & $\begin{array}{c}8.3^{\circ} \mathrm{F} / \mathrm{day}^{3} \\
7 / 2 / 1957 \text { to } \\
7 / 16 / 1957\end{array}$ & $\begin{array}{c}399^{\circ} \mathrm{F} \text { June } \\
1961\end{array}$ & $\begin{array}{l}17 \text { months } \\
>300^{\circ} \mathrm{F}\end{array}$ & - & - \\
\hline A-102 & 3/22/1956 & 3/13/1958 & $\begin{array}{l}\text { P, OWW, B, } \\
\text { AR, PSS }\end{array}$ & - & No & No & $1 / 24 / 1956$ & $\sim 2$ months & - & Yes & $\begin{array}{c}6^{\circ} \mathrm{F} / \mathrm{day}^{3} \\
8 / 1 / 1961 \text { to } \\
8 / 12 / 1961\end{array}$ & $\begin{array}{c}380^{\circ} \mathrm{F} \text { Aug. } \\
1961\end{array}$ & $\begin{array}{l}3 \text { months } \\
>300^{\circ} \mathrm{F}\end{array}$ & - & - \\
\hline A-103 & $5 / 17 / 1956$ & 7/5/1956 & $\begin{array}{l}\text { P, OWW, B, } \\
\text { AR, IX, PSS }\end{array}$ & - & $\begin{array}{l}\text { D-42 Concluded } \\
\text { Sound Tank }{ }^{4}\end{array}$ & No & $1 / 24 / 1956$ & $\sim 4$ months & - & Yes & $\begin{array}{c}4.5^{\circ} \mathrm{F} / \mathrm{day} \\
5 / 28 / 1956 \text { to } \\
6 / 28 / 1956 \\
\text { (initial) } \\
\end{array}$ & $\begin{array}{c}446^{\circ} \mathrm{F} \text { April } \\
22,1957\end{array}$ & $\begin{array}{l}1 \text { month } \\
>300^{\circ} \mathrm{F}\end{array}$ & $\begin{array}{l}\text { Yes-July } 5 \text { to } \\
12,1956^{1}\end{array}$ & $\begin{array}{l}\text { 1-12 in. } \\
\text { Water }^{1}\end{array}$ \\
\hline A-106 & July 1961 & $\begin{array}{c}\text { Before } \\
12 / 31 / 1961\end{array}$ & $\begin{array}{c}\mathrm{P}, \mathrm{OWW}, \mathrm{B}, \\
\mathrm{AR}\end{array}$ & - & No & No & $1 / 24 / 1956$ & $\sim 68$ months & - & Yes & $\begin{array}{c}6.3^{\circ} \mathrm{F} / \mathrm{day}^{3} \\
4 / 3 / 1963 \text { to } \\
5 / 16 / 1963\end{array}$ & $\begin{array}{c}594^{\circ} \mathrm{F} \text { May } \\
16,1963\end{array}$ & $\begin{array}{l}76 \text { months } \\
>300^{\circ} \mathrm{F}\end{array}$ & - & - \\
\hline
\end{tabular}

Note: Reference HW-41791 Pt 1, PUREX Waste Storage. Part 1 - 241-A Waste Storage Facilities 3/7/56 General Electric, States that 6-in of water was added to all A Farm tanks 1/24/56.
Where dashes are used in the

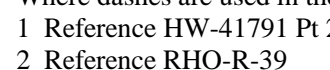

3 Initial temperature rate of rise unknown

4 Reference RPP-ASMT-42278, Tank 241-A-103 Leak Assessment Report 
RPP-RPT-54912, Rev. 0

\subsection{REFERENCES}

ARH-78, 1967, PUREX TK-105-A Waste Storage Tank Liner Instability and its Implications on Waste Containment and Control, Atlantic Richfield Hanford Company, Richland, Washington.

ARH-534, 1968, Chemical Processing Division Waste Status Summary January 1, 1968 through March 31, 1968, Atlantic Richfield Hanford Company, Richland, Washington.

ARH-1200 A, 1969, Chemical Processing Division Waste Status Summary January 1, 1969 through March 31, 1969, Atlantic Richfield Hanford Company, Richland, Washington.

ARH-1200 B, 1969, Chemical Processing Division Waste Status Summary April 1, 1969 through June 30, 1969, Atlantic Richfield Hanford Company, Richland, Washington.

ARH-1200 D, 1970, Chemical Processing Division Waste Status Summary October 1, 1969 through December 31, 1969, Atlantic Richfield Hanford Company, Richland, Washington.

ARH-1515, 1969, Atlantic Richfield Hanford Company Semiannual Report Process Development May 1, 1969 through October 31, 1969, Atlantic Richfield Hanford Company, Richland, Washington.

ARH-1601, 1974, Specifications and Standards for the Operation of Radioactive Waste Tank Farms and Associated Facilities, Atlantic Richfield Hanford Company, Richland, Washington.

ARH-2456 A, 1972, Chemical Processing Division Waste Status Summary April 1, 1972 through June 30, 1972, Atlantic Richfield Hanford Company, Richland, Washington.

ARH-2456 B, 1972, Chemical Processing Division Waste Status Summary April 1, 1972 through June 30, 1972, Atlantic Richfield Hanford Company, Richland, Washington.

ARH-2456 C, 1972, Chemical Processing Division Waste Status Summary July 1, 1972 through September 30, 1972, Atlantic Richfield Hanford Company, Richland, Washington.

ARH-2456 D, 1973, Chemical Processing Division Waste Status Summary October 1, 1972 through December 1, 1972, Atlantic Richfield Hanford Company, Richland, Washington.

ARH-CD-133 A, 1974, Operations Division Waste Status Summary January 1, 1974 through March 31, 1974, Atlantic Richfield Hanford Company, Richland, Washington.

ARH-CD-133 B, 1974, Operations Division Waste Status Summary April 1, 1974 through June 30, 1974, Atlantic Richfield Hanford Company, Richland, Washington.

ARH-LD-120, 1975, Nuclear Waste Tank and Pipeline External Leak Detection Systems, Atlantic Richfield Hanford Company, Richland, Washington. 
ARH-R-43, 1970, Management of Radioactive Wastes Stored in Underground Tanks at Hanford, Rev. 2, Atlantic Richfield Hanford Company, Richland, Washington.

ASTM A283, 1946, American Society for Testing and Materials, Standard Specification for Low and Intermediate Tensile Strength Carbon Steel Plates.

BPF-73550, 1944, Specification for Construction of Composite Storage Tanks (B, C, T, and U Tank Farms), Hanford Engineer Works, Richland, Washington.

ERDA-1538, 1975, Final Environmental Statement, Vol. 2, December, Hanford Reservation, Richland, Washington.

GJ-HAN-106, 1998, Vadose Zone Monitoring Project at the Hanford Tank Farms Tank Summary Data Report for Tank A-101, U.S. Department of Energy Grand Junction Projects Office, Grand Junction, Colorado.

GJ-HAN-107, 1998, Vadose Zone Monitoring Project at the Hanford Tank Farms Tank Summary Data Report for Tank A-102, U.S. Department of Energy Grand Junction Projects Office, Grand Junction, Colorado.

GJ-HAN-108, 1998, Vadose Zone Monitoring Project at the Hanford Tank Farms Tank Summary Data Report for Tank A-103, U.S. Department of Energy Grand Junction Projects Office, Grand Junction, Colorado.

GJ-HAN-109, 1998, Vadose Zone Monitoring Project at the Hanford Tank Farms Tank Summary Data Report for Tank A-104, U.S. Department of Energy Grand Junction Projects Office, Grand Junction, Colorado.

GJ-HAN-110, 1998, Vadose Zone Monitoring Project at the Hanford Tank Farms Tank Summary Data Report for Tank A-105, U.S. Department of Energy Grand Junction Projects Office, Grand Junction, Colorado.

GJ-HAN-111, 1998, Vadose Zone Monitoring Project at the Hanford Tank Farms Tank Summary Data Report for Tank A-106, U.S. Department of Energy Grand Junction Projects Office, Grand Junction, Colorado.

GJO-HAN-18, 1998, Vadose Zone Monitoring Project at the Hanford Tank Farms C Tank Farm Report, U.S. Department of Energy Grand Junction Projects Office, Grand Junction, Colorado.

GJO-HAN-23, 1999, Vadose Zone Monitoring Project at the Hanford Tank Farms A Tank Farm Report, U.S. Department of Energy Grand Junction Projects Office, Grand Junction, Colorado.

H-2-35091, 1969, Tk-104-A Heater, Atlantic Richfield Hanford Company, Richland, Washington. 
H-2-39512, 1954, 75 FT. Tank Base Footing and Wall Reinforcing, Waste Disposal Facility, 241-SX, General Electric Company, Richland, Washington.

H-2-55911, 1956, Waste Storage Tanks Composite Section, General Electric Company, Richland, Washington.

H-2-55912, 1956, Base Footing and Wall Reinforcing, PUREX Waste Disposal Facility, General Electric Company, Richland, Washington.

H-2-56342, 1955, Details Air-Lift Circulator, General Electric Company, Richland, Washington.

H-2-56350, 1955, Arrangement Air-Lift Circulators, General Electric Company, Richland, Washington.

HNF-3018, 1998, Single-Shell Tank Sluicing History and Failure Frequency, Rev. 0, COGEMA Engineering Corporation, Richland, Washington.

HW-4926-S, 1968, Standard Specification for Welding Carbon Steels, Rev. 9, Hanford Works Standards Committee, Richland, Washington.

HW-51348, 1957, Chemical Processing Department Waste Status Summary for June 1, 1957 through June 30, 1957, General Electric Company, Richland, Washington.

HW-57274, 1958, Instability of Steel Bottoms in Waste Storage Tanks, General Electric Company, Richland, Washington.

HW-57328-DEL, 1958, Chemical Processing Department Monthly Report for August 1958, Hanford Atomic Products Operation, Richland, Washington.

HW-59079-DEL, 1959, Chemical Processing Department Monthly Report for January 1959, Hanford Atomic Products Operation, Richland, Washington.

HW-59919, 1959, Limitations for Existing Storage Tanks for Radioactive Wastes from Separations Plants, General Electric Company, Richland, Washington.

HW-60749, 1959, Leak Detection System for Active Tanks Interim Report, General Electric Company, Richland, Washington.

HW-61952, 1959, Chemical Processing Department Waste Status Summary August 1, 1959 through August 31, 1959, Hanford Atomic Products Operation, Richland, Washington.

HW-67698, 1960, Preliminary Report on the Characterization of PUREX Tank Farm Radioactive Condensate Waste, General Electric Company, Richland, Washington. 
HW-68661, 1961, Proposed Leak Detection System for Existing Storage Tanks Containing SelfBoiling Radioactive Wastes (Scope and Design Criteria), General Electric Company, Richland, Washington.

HW-74914, 1962, PUREX Tank Farm Fill Program, General Electric Company, Richland, Washington.

HW-76443, 1963, Chemical Processing Department Monthly Report January 1963, General Electric Company, Richland, Washington.

HW-76848, 1963, Chemical Processing Department Monthly Report February 1963, General Electric Company, Richland, Washington.

HW-83906-C-RD, 1964, Chemical Processing Department 200 West Area Tank Farm Inventory and Waste Reports January 1957 Through December 1958, General Electric Company, Richland, Washington.

HWS-5614, 1953, Specifications for Purex Waste Disposal Facility, Project CA-513-A, General Electric Company, Richland, Washington.

IDMS Accession \#D196248072, Analysis of Tank Farm Samples Sample: T-2893 Tank 104-A, dated March 4, 1974, Atlantic Richfield Hanford Company, Richland Washington.

IDMS Accession \#D197260431, History - 241-A Tank Farm, memo dated May 21, 1963 D. L. Uebelackler, General Electric Company, Richland Washington.

Internal Letter, "Dissolution of TK-105-A Sludge with Inhibited Sulfuric Acid," (internal letter from W. C. Schmidt and P. W. Smith to R. E. Smith, December 23), Atlantic Richfield Hanford Company, Richland, Washington.

Interoffice Memo 7G420-06-004, 2006, "Estimation of Tank 241-A-105 Supernatant Cesium137 Concentration during Sluicing in August 1968," (internal memorandum from Technical Integration Program to J. G. Field, February 28), CH2M Hill Hanford Group, Inc., Richland, Washington.

Interoffice Memo 7G420-06-005, 2006, "Estimation of Tank 241-A-105 Supernatant Cesium137 Concentration during Second Sluicing Campaign Conducted July 1969 through November 1970," (internal memorandum from Technical Integration Program to J. G. Field, March 22), CH2M Hill Hanford Group, Inc., Richland, Washington.

LET-070357, 1957, “Commentary Report for Structural Review and Cost Estimate of the Tank Designs," (internal letter from H.W. Stivers to J.B. Fecht, July 3), General Electric Company, Richland, Washington. 
Oblath, S. B. and J. W. Congdon, 1987, "Inhibiting Localized Corrosion during Storage of Dilute SRP Waste", Waste Management '87, Volume 1, Tucson, AZ: Arizona Board of Regents: 599-602.

OR 74-130, 1974, Occurrence Report 74-130, Contamination Spread, Atlantic Richfield Hanford Company, Richland, Washington.

OR 75-39, 1975, Occurrence Report 75-39, Leakage from Tank 104-A, Atlantic Richfield Hanford Company, Richland, Washington.

OSD-T-151-00007, 2013, Operating Specifications for the Double-Shell Storage Tanks, Rev. 12, Washington River Protection Solutions, LLC., Richland, Washington.

OSD-T-151-00017, 1983, Operating Specifications for the Aging Waste Operations in Tank Farms 241-AY and 241-AZ, Rev. B-0, Rockwell Hanford Operations, Richland, Washington.

PNL-5488, 1985, Prediction Equations for Corrosion Rates of A-537 and A-516 Steels in Double Shell Flurry, Future Purex, and Hanford Facilities Wastes, Pacific Northwest Laboratory, Richland, Washington.

PNNL-15160, 2005, Hanford Site Climatological Summary 2004 with Historical Data, Pacific Northwest National Laboratory, Richland, Washington.

RHO-CD-213, 1977, Waste Storage Tank Status and Leak Detection Criteria 200 East AreaVolume 1, Atlantic Richfield Hanford Company, Richland, Washington.

RHO-CD-255, 1978, Tank 105-A Stabilization Progress Report, Rockwell Hanford Operations, Richland, Washington.

RHO-CD-1172, 1981, Survey of the Single-Shell Tank Thermal Histories, Rockwell Hanford Operations, Richland, Washington.

RHO-R-39, 1969, Boiling Waste Tank Farm Operational History, Rockwell Hanford Operations, Richland, Washington.

RHO-ST-30, 1980, Hanford Radioactive Tank Cleanout and Sludge Processing, Rockwell Hanford Operations, Richland, Washington.

RHO-ST-34, 1981, A Scientific Basis for Establishing Drywell-Monitoring Frequencies, Rockwell Hanford Operations, Richland, Washington.

RL-SEP-87, 1964, PUREX Waste Tank 241-A-105 Fill Limit, General Electric Company, Richland, Washington. 
RL-SEP-183 RD, 1964, PUREX Tank Farm Supernatant Solution Composition, General Electric Company, Richland, Washington.

RL-SEP-239, 1965, By-Product Recovery during Waste Processing Engineering Study, General Electric Company, Richland, Washington.

RL-SEP-509, 1965, Chemical Processing Department Monthly Report for May 1965, General Electric Company, Richland, Washington.

RL-SEP-659, 1965, Chemical Processing Department Waste Status Summary January 1, 1965 through June 30, 1965, General Electric Company, Richland, Washington.

RPP-8820, 2003, Analysis and Summary Report of Historical Dry Well Gamma Logs for the 241-A Tank Farm- 200 East, Rev. 0, CH2M Hill Hanford Group, Inc., Richland, Washington.

RPP-32681, 2011, Process to Assess Tank Farm Leaks in Support of Retrieval and Closure Planning, Rev. 1, Washington River Protection Solutions, LLC., Richland, Washington.

RPP-RPT-33306, 2008, IQRPE Integrity Assessment Report for the 242-A Evaporator Tank System, Rev. 0A, CH2M Hill Hanford Group, Inc., Richland, Washington.

RPP-35484, 2007, Field Investigation Report for Waste Management Areas C and A-AX, CH2M Hill Hanford Group, Inc., Richland, Washington.

RPP-ASMT-42278, 2009, Tank 241-A-103 Leak Assessment Report, Rev. 0, Washington River Protection Solutions, LLC., Richland, Washington.

RPP-ASMT-53793, 2012, Tank 241-AY-102 Leak Assessment Report, Rev. 0, Washington River Protection Solutions, LLC., Richland, Washington.

RPP-ENV-37956, 2008, Hanford $A$ and AX-Farm Leak Assessments Report: 241-A-103, 241-A104, 241-A-105, 241-AX-102, 241-AX-104 and Unplanned Waste Releases, Rev. 1, CH2M Hill Hanford Group, Inc., Richland, Washington.

RPP-RPT-27605, 2006, Gamma Surveys of the Single-Shell Tank Laterals for A and SX Tank Farms, Rev. 0, CH2M Hill Hanford Group, Inc., Richland, Washington.

RPP-RPT-45921, 2010, Single Shell Tank Integrity Expert Panel Report, Rev. 0, Washington River Protection Solutions, LLC., Richland, Washington.

RPP-RPT-47337, 2011, Specifications for the Mineralization of the Stress Corrosion Cracking Threat in Double-Shell Tank Wastes, Rev. 0, Washington River Protection Solutions, LLC., Richland, Washington. 
RPP-RPT-54909, TBD, Hanford Single-Shell Tank Leak Causes and Locations - Summary, Washington River Protection Solutions, LLC., Richland, Washington.

SD-WM-TI-302, 1987, Hanford Waste Tank Sluicing History, Westinghouse Hanford Company, Richland, Washington.

SD-WM-TI-356, 1988, Waste Storage Tank Status and Leak Detection Criteria, Rev. 0, Westinghouse Hanford Company, Richland, Washington.

TFC-ENG-CHEM-D-42, 2009, Tank Leak Assessment Process, Rev. B-2, CH2M HILL Hanford Group, Inc., Richland, Washington.

TRAC-0022, 1978, An Estimate of Bottom Topography, Volume, and Other Conditions in Tank 105A, Hanford, Washington, Woodward-Clyde Consultants, San Francisco, California.

WHC-EP-0182, 1991, Tank Farm Surveillance and Waste Status Report for September 1991, Rev. 42, Westinghouse Hanford Company, Richland, Washington.

WHC-EP-0410, 1991, Tank 241-A-105 Evaporation Estimate 1970 through 1978, Westinghouse Hanford Company, Richland, Washington.

WHC-EP-0412, 1991, Fate and Transport of Constituents Leaked from Tank 241-A-105, Westinghouse Hanford Company, Richland, Washington.

WHC-EP-0772, 1994, Characterization of the Corrosion Behavior of the Carbon Steel Liner in Hanford Site Single-Shell Tanks, Westinghouse Hanford Company, Richland, Washington.

WHC-EP-0449, 1991, The Sort on Radioactive Waste Type Model: A Method to Sort SingleShell Tanks into Characteristic Groups, Westinghouse Hanford Company, Richland, Washington.

WHC-MR-0264, 1991, Tank 241-A-105 Leak Assessment, Westinghouse Hanford Company, Richland, Washington.

WHC-SD-WM-ER-349, 1994, Historical Tank Content Estimate for the Northeast Quadrant of the Hanford 200 East Area, Rev. 0, Westinghouse Hanford Company, Richland, Washington.

WHC-SD-WM-TI-665, 2004, Soil Load above Hanford Waste Storage Tanks, Rev. 0D, CH2M Hill Hanford Group, Inc., Richland, Washington.

WSRC-TR-90-512, 1990, Effect of Temperature on the Nitrite Requirement to Inhibit Washed Sludge, Westinghouse Savannah River Company, Aiken, South Carolina. 
RPP-RPT-54912, Rev. 0

APPENDIX A

\section{MEETING MINUTES}

December 3, 2012

January 15, 2013 


$\begin{array}{ll}\text { From: } & \text { C. L. Girardot Cystal Gisasctot } \\ \text { Phone: } & \text { 376-0528 } \\ \text { Location: } & \text { Ecology Office, } \\ \text { Date: } & \text { December 3, 2012 } \\ \text { Subject: } & \text { Tank Farm Leak Integrity Assessments } \\ & \text { Distribution/Attendees }\end{array}$

Attendees:

$\begin{array}{ll}\text { Jim Alzheimer, ECOLOGY } & \text { Jeff Luke, WRPS } \\ \text { Mike Barnes, ECOLOGY } & \text { Jeff Lyon, ECOLOGY } \\ \text { Crystal Girardot, WRPS } & \text { Ted Venetz, WRPS } \\ \text { Don Harlow, WRPS } & \text { Dennis Washenfelder, WRPS } \\ \text { Jeremy Johnson, ORP } & \end{array}$

\section{PURPOSE:}

The purpose of this meeting was to:

1) Kick off Fiscal Year (FY) 2013 Leak Location and Cause status meetings with ORP and ECOLOGY

2) Summarize Leak Location and Cause status and outline FY 2013 schedule

3) Discuss Tank A-105 Leak Location and Cause preliminary summary

\section{Leak Location and Cause Status and Schedule}

To date, the Leak Location and Cause reports for SX Farm, BY Farm, and TY Farm have been prepared, reviewed, and comments from ECOLOGY and ORP have been incorporated. This work was completed at the end of FY 2011.

For FY 2013, a Leak Location and Cause report will be completed for the following tanks: A104, A-105, B-107, C-101, C-105, T-106, T-107, U-104, U-110, and U-112. There is a possibility of more tanks to be added to this list once the T Farm and TX Farm assessment reports are completed per RPP-RPT-32681.

\section{SX Farm}

SX Farm was discussed briefly and it was asked if welding maps were available for SX Farm as well as additional information about hydrostatic testing procedures of the SX Farm steel liners during construction and if there are any available photographs of the bottom of the tank liner after hydrostatic testing. The condition of the bottom of the steel liner after hydrostatic testing was questioned and what deformations if any were in evidence. This will be looked into in more detail and the SX Farm report will be updated as required. 


\section{Tank A-105 Leak Location and Cause Summary}

The preliminary results from the tank A-105 analysis were discussed. It was determined that the leak from tank A-105 was first detected in lateral 14-05-03 in November 1963. However, since radioactivity in the lateral stabilized and then started to decline shortly after, the tank was kept in service.

In January 1965, a steam eruption occurred in tank A-105 resulting in the bottom liner tearing approximately $3 / 4$ the way around the tank. Tank A-105 was declared a confirmed leaker in March 1968, supernatant was removed from the tank, and sluicing campaigns occurred in 1968 and 1970.

One possible leak cause could have occurred when tank A-105 aged HLW supernatant was pumped out of the tank in January 1963 leaving the liquid level at 10-in. If adequate time was not allowed for dissipation of grout moisture under the tank bottom liner before pumping, this may have resulted in an initial bulged tank bottom liner if the vapor pressure below the tank bottom liner exceeded the hydrostatic pressure. Unexplained liquid level fluctuations occurred in September 1963, some as large as 12-in, further supporting a compromised liner. A bulged liner failure may have allowed subsequent condensate and/or concentrated HLW to be trapped below the tank bottom liner. Any trapped liquid coupled with the increased hydrostatic pressure and temperature of the concentrated 11,000 tons equivalent HLW in the tank, ultimately resulted in the January 1965 steam eruption and ripped liner.

A tank leak cause matrix (blame button chart) was presented with tank design being the primary contributor to a tank A-105 leak with a bulging liner being the next likely contributor. It was suggested to add an additional category to this chart for tank A-105 to account for the January 1963 pump out of the supernatant as explained above. It was suggested that the blame button chart needs to be reviewed for possible revision. A preliminary draft of the tank A-105 segment was distributed at the meeting.

A final draft of the tank A-105 segment will be completed and distributed prior to the next meeting.

\section{ACTIONS:}

1. All: Review meeting summary for discussion in the next meeting.

Status: Completed

2. C. Girardot: Prepare and distribute December 3, 2012 Meeting Summary. Status: Completed

3. C. Girardot/D. Harlow: Complete Tank A-105 Leak Location and Cause report and distribute (incorporate any comments as appropriate).

Status: Report completed with comment(s) incorporated, see attached.

4. C. Girardot/D. Harlow: Find information on SX Farm plates including photos and construction and update SX Farm report as required.

Status: Completed. Additional boxes have been searched and no information was found.

5. C. Girardot/D. Harlow: Review the tank leak cause matrix (blame button chart).

Status: Completed. Added additional category to both the blame button chart and the attendant Leak Cause Matrix. 
RPP-RPT-54912, Rev. 0

6. All: Meet to review the Leak Loss status (RPP-RPT-32681) and identify what needs to be revised/updated.

Status: Completed. Passed on to the Closure \& Corrective Measures group.

\section{NEXT MEETING:}

Tuesday January 15, 2013 


\section{RPP-RPT-54912, Rev. 0}

A Farm Report, RPP-RPT-54912, Rev. 0, Tank A-105, Comments and Resolutions - J. A. Caggiano

\section{January 24,2013}

1. There are unconfirmed reports of tank liner bulging where the bulged liner returned to the normal configuration. In some cases the bulging steel may have remained within elastic limits and did not reach the failure point. Would multiple bulging events weaken the bottom such that it might contribute to ultimate failure? Consider addressing this possibility.

Response: Added multiple bulging effects to section 3.2.3 and the individual tank segment sections 4.4.3 and 5.4.3. 
RPP-RPT-54912, Rev. 0

MEETING SUMMARY

$\begin{array}{ll}\text { From: } & \begin{array}{l}\text { C. L. Girardot } \\ \text { Phone: }\end{array} \\ \text { Location: } & \text { Ecology Office } \\ \text { Date: } & \text { January 15, } 2013 \\ \text { Subject: } & \text { Tank Farm Leak Integrity Assessments } \\ & \text { Distribution/Attendees }\end{array}$

Attendees:

$\begin{array}{ll}\text { Jim Alzheimer, ECOLOGY } & \text { Crystal Girardot, WRPS } \\ \text { Mike Barnes, ECOLOGY } & \text { Don Harlow, WRPS } \\ \text { Joe Caggiano, ECOLOGY } & \text { Ted Venetz, WRPS } \\ \text { Jim Field, WRPS } & \text { Dennis Washenfelder, WRPS }\end{array}$

Les Fort, WRPS

\section{PURPOSE:}

The purpose of this meeting was to discuss the Tank A-104 Leak Location and Cause summary.

\section{Tank A-104 Leak Location and Cause Summary}

The results from the tank A-104 analysis were discussed. It was determined that the leak from tank A-104 was first detected in lateral 14-04-02 in the northern portion of the tank in March 1975 shortly after the start of sluicing the tank in September 1974. This was the first indication of a tank A-104 leak. Radioactivity in lateral 14-04-02 continued to increase a week later. In April 1975, radioactivity was first detected in lateral 14-04-01 underneath the southern edge of the tank possibly due to a new leak site. A couple of weeks later, radioactivity was first detected in lateral 14-04-03 underneath the northern portion of the tank, likely due to migration from the earlier leak detected in lateral 14-04-02. During this time, no radioactivity was detected in the surrounding drywells that could be indicative of a tank leak.

At the end of 1969, tank A-104 was filled with $957 \mathrm{kgal}$ of water for a leak test to confirm integrity and the tank was declared a spare. The reason for this leak test remains unknown.

Possible leak causes that were identified for tank A-104 included: tank design, liner bulging, thermal conditions, chemistry-corrosion, and tank construction conditions. No one cause was identified that could be the primary contributor to the tank leak.

It was suggested to investigate the waste transfers into and out of tank A-104 during the time when the maximum temperature spike occurred in 1963 and update the report. It is unclear why there was a spike in temperature in February 1963 as Organic Wash Waste (OWW) was being added to the tank to control temperature from January 30, 1963 through February 15, 1963. The PUREX Plant outage in December 1962 through January 1963 resulted in the lack of OWW for 
tank A-104 temperature control. Portable compressors were used to supply additional air to the air lift circulators which reduced the tank A-104 temperature.

One observation was made about the lateral radioactivity detected from March to May 1975 and the relatively fast spread of radioactivity detected during this time. It was asked if a leak rate would be able to be calculated from the lateral data. Information will be made available for the calculation of leak rates to be provided in a separate document.

The question of whether sluicing could be a contributor to a tank liner leak was also asked or if sluicing could unplug previously undetected leak sites. It was concluded that these possibilities may be more evident as further analyses are performed on the remaining leaking single-shell tanks. A note was suggested to be added to the tank leak cause matrix table regarding the possible linkage between sluicing and leaks.

A draft tank leak cause matrix table was presented showing a summary of causal factors contributing to leaks of all tanks assessed thus far and updated to include tank A-104. This matrix will be revisited as each tank is assessed.

The conclusions for the 241-A Farm Leak Cause and Locations report will be distributed prior to the next meeting. The draft Tank B-107 report will be discussed in the next meeting.

\section{ACTIONS:}

7. All: Review meeting summary for discussion in the next meeting.

\section{Status: Completed}

8. C. Girardot: Prepare and distribute January 15, 2013 Meeting Summary.

Status: Completed

9. C. Girardot/D. Harlow: Complete A Farm Leak Location and Cause report including Tank A-104 segment and distribute (incorporate any comments as appropriate).

Status: Report completed with comment(s) incorporated, see attached.

10. C. Girardot/D. Harlow: Find information on SX Farm plates including photos and construction and update SX Farm report as required.

Status: Completed. Additional boxes have been searched and no information was found.

11. D. Harlow: See about tank T-111 and if this needs to be added to the list of tanks to be analyzed for Leak Location and Cause.

Status: Not currently listed. The RPP-RPT-32681, T Farm Leak Assessment, will address all T Farm tanks.

12. C. Girardot/D. Harlow: Prepare the tank B-107 Leak Location and Cause report to be discussed in the next meeting.

Status: Completed.

\section{NEXT MEETING:}

Part 1. TX Farm Leak Assessment. Part 2. Review tank B-107 leak location and causes.

Date: $\quad$ February 5 (Part 1 and Part 2)

Time: 2:30-4:00

Location: ECOLOGY Office 
RPP-RPT-54912, Rev. 0

A Farm Report, RPP-RPT-54912, Rev. 0 Comments and Resolutions - J. A. Caggiano

January 24,2013

2. Figure 2-1 shows A-103 as an assumed leaker, as it does in the Hanlon report. Other places discuss the two leakers in A Farm A-104 and A-105. Should either label Figure 2-1 or correct the figure to be consistent with what is said in the text.

Response: Added a footnote to Figure 2-1 to address the recommendation to change the Tank A-103 designation from "Assumed Leaker" to "Sound Tank" in RPP-ASMT42278, Tank 241-A-103 Leak Assessment Report. 